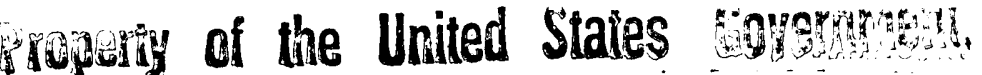

Bulletin No. 283

Series $\left\{\begin{array}{l}\text { A, Economic Geology, 7! } \\ \text { B, Descriptive Geology, } 92\end{array}\right.$

DEPARTMENT' OF THE INTERIOR

UNITED STATES GEOLOGICAL SURVEY

CHARLES D. WALCO'T'T,_DIRECTOK

\section{GEOLOGY AND MINERAL RESOURCES OF MISSISSIPPI}

BY

A. F.C CRIER

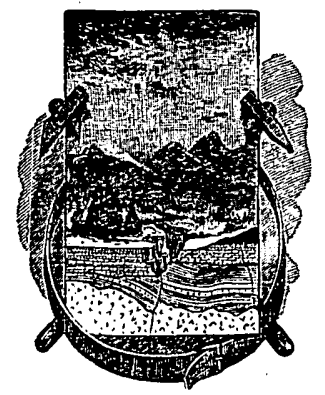

WASHINGTON

GOVERNMENT PRINTING OFICE

1906 



\section{CONTENTS.}

Introduction by Edwin C. Eckel $\quad . \quad, \quad \therefore \quad \ldots \quad$ Page.

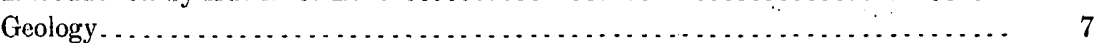

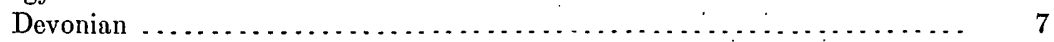

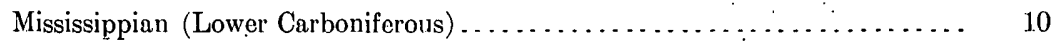

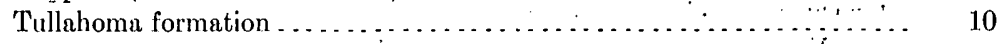

St. Louis limestone. . . . . . . . . . . . . . 11

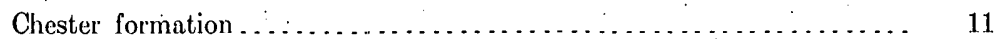

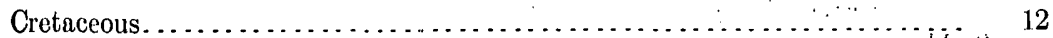

Tuscaloosa formation . . . . . . . . . . . . . . . . . . . . . .

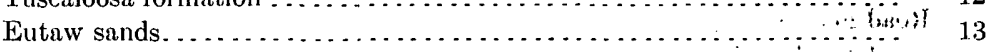

Selma chalk ... . . . . . . . . . . . . . . . . . . . . .

Ripley formation. . . . . . . . . . . . . . . . . . . . . .

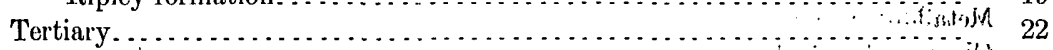

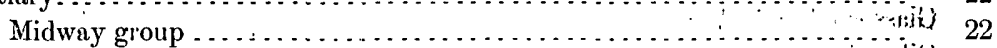

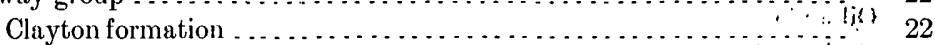

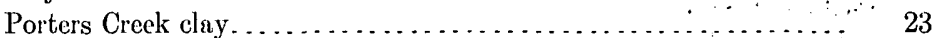

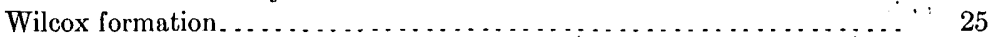

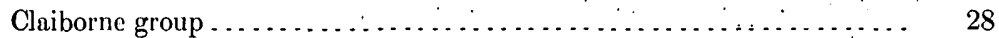

Tallahatta buhrstone $\ldots \ldots \ldots \ldots \ldots \ldots \ldots \ldots \ldots \ldots \ldots \ldots \ldots \ldots . \ldots \ldots$

Lisbon beds .................................. 33

Jackson formation. ................................... 33

Vicksburg formation . . . . . . . . . . . . . . . . . . . . 37

Pascagoula formation. ................................ 40

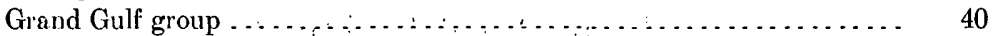

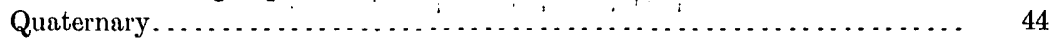

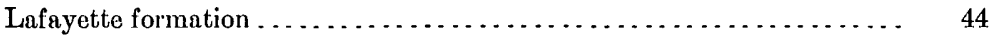

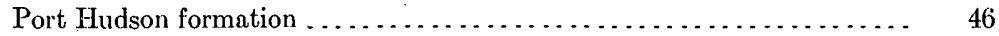

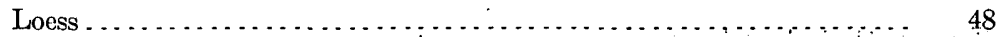

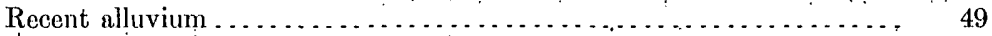

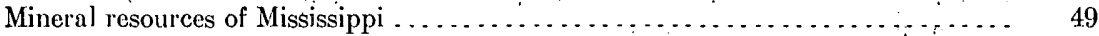

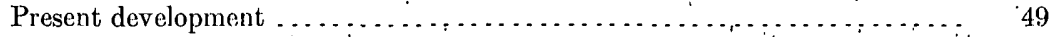

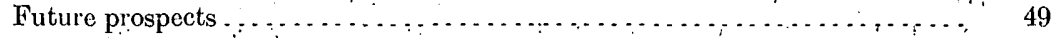

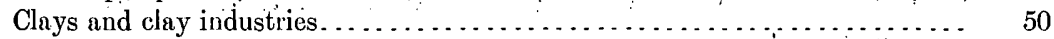

Clays of the Tuscaloosa formation (lower Cretaceous) $\ldots \ldots \ldots \ldots \ldots \ldots . \quad 50$

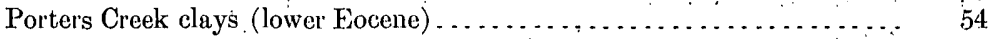

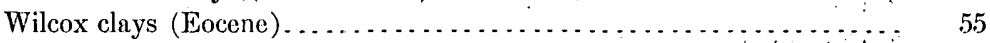

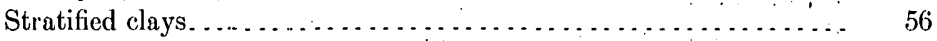

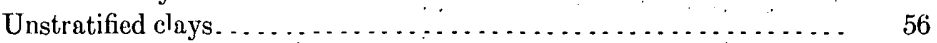

Notes on Wilcox clays ............................... 56

Clays of the Jackson formation (upper Eocene) ................. 66

Clays of the Giand Gulf group (Miocene) . . . . . . . . . . . . . . . . . . 67

Lafayette clays (early Quaternary) ........................ 68

Loess and yellow-loam brick clays (Quaternary) . . . . . . . . . . . 69

Quaternary clays of the Gulf const. . . . . . . . . . . . . . . . . . 70

Quaternary clays of the Yazoo delta....................... 71 
Mineral resources of Mississippi-Continued. Page.

Cement materials, by Edwin C. Eckel. ........................ 71

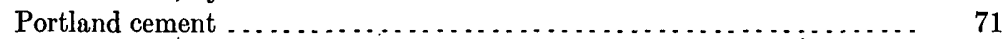

Cement materials in general . . . . . . . . . . . . . . . . . . . . . . . 72

Essential conditions ................................ 72

Chemical composition. .............................. 73

Physical composition ................................. 74

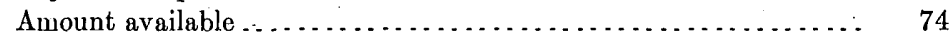

Location with respect to transportation routes . . . . . . . . . . . . . . $\quad 74$

Location with respect to fuel supplies. . . . . . . . . . . . . . . . . $\quad 74$

Location with respect to markets. . . . . . . . . . . . . . . . . $\quad 75$

Cost of equipment and erection . . . . . . . . . . . . . . . . . $\quad 75$

Total capital required. . . . . . . . . . . . . . . . . . . . . . . $\quad 75$

Cement materials in Mississippi . . . . . . . . . . . . . . . . . . . . . $\quad 75$

Mississippian (Lower Carboniferous) limestones. . . . . . . . . . . $\quad 76$

Cretaceous limestone (Selma chalk or rotten limestone) ......... 76

Tertiary limestone (Vicksburg limestone) . . . . . . . . . . . . . . . . 84

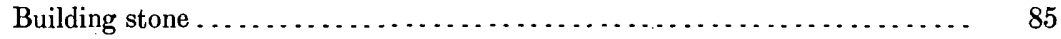

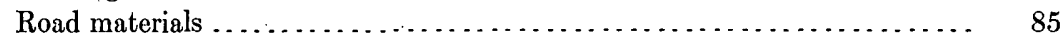

Gravel or shingle. . . . . . . . . .

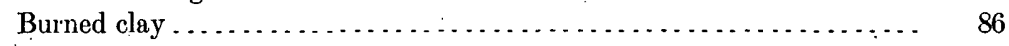

Metalliferous ores. . . . . . . . . . . . . . . . . . . .

Glass sand and silica. . . . . . . . . . . . . . . . .

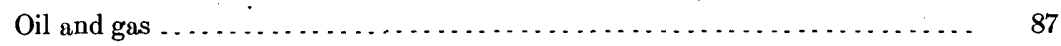

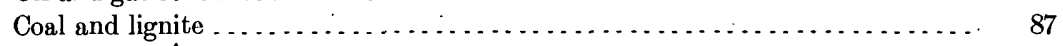

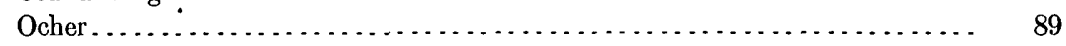

Phosphates, greensands, marls, and other fertilizers. . . . . . . . . . . . . . . 89

Mineral waters . . . . . . . . . . . . . . . . .

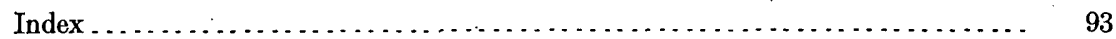

\section{L L U S T R A T I 0 N S.}

Page.

II. $A$, Outcrop of Vicksburg limestone at Rock Cut 1 mile west of Clinton; $B$, Tuscaloosa sands near Iuka . . . . . . . . . . . . . . . . . . . . . 12

III. $A$, Selma chalk bluff, Macon; $B$, Loess bluff, Yazoo City . . . . . . . . . . . 18

IV. $A$, Bed of glass sand on Pearl River near Byram; $B$, Ledge of Tallahatta

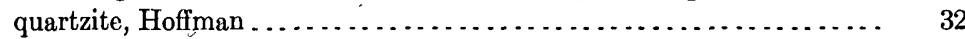

Fia. 1. Cross section from mouth of Yellow Creek to Mingo . . . . . . . . . . . . . 7

2. Cross section from the Alabama line to Mississippi River............. 8

3. Cross section from West Point to Greenville $\ldots \ldots \ldots \ldots \ldots \ldots \ldots \ldots \ldots$

4. Cross section from Gattman to Fort Adams . . . . . . . . . . . . . . . . .

5. Cross section from Scranton to Tennessee River.................. . 9 


\section{GEOLOGY AND MINERAL RESOURCES OF MISSISSIPPI.}

Bỳ A. F. Crider.

\section{INTRODUCTION.}

By EDwiN C. ECKEL.,

The following sketch of the geology and mineral resources of the State of Mississippi has been prepared to serve as a summary of present knowledge of those subjects. Much detailed field work in the State will.be required before any complete discussion of its geology can be presented, but it is hoped that the outline given here will be of service, particularly in indicating the lines along which the development of Mississippi's mineral resources will probably take place.

It is with pleasure that this opportunity is taken of acknowledging indebtedness to previous workers in the same field. In the preparation of the present sketch free use has been made of the various reports and papers published by Dr. Eugene Hilgard, former State geologist. Dr. Eugene A. Smith, formerly assistant to Doctor Hilgard and now State geologist of Alabama, has very generously furnished notes on various phases of Mississippi geology. Mr. L. C. Johnson, of Pachuta, Miss., who has spent many years in geologic work in the State, has also contributed numerous data.

In a paper recently published in the Transactions of the Mississippi Historical Society, Doctor Hilgard has given an outline of the principal events in the history of the Geological and Agricultural Survey of the State of Mississippi, from its formation in 1850 to its untimely cutting off in 1872. A summary of this valuable outline is as follows:

The Geological and Agricultural Survey of the State of Mississippi had its origin in an act of the legislature entitled "An act to further endow the University of Mississippi," which was approved by the governor March 5, 1850, and took effect June 1 following. This act provided that $\$ 3,000$ should be semiannually appropriated for the support of the agricultural and geologic departments of the university, at least one-half of which sum was to be expended in making a general geologic and agricultural survey of the State. Annual reports were to be made to the governor by the trustees of the university. This act, together with later legislation in 1852, 1854, and 1860, was the basis of all geologic work carried on by the State.

In 1852, Prof. B. L. C. Wailes took up active work under the act of 1850, and in 1854 an appropriation for the publication of his report was made by the legislature. Professor Wailes was succeeded as State geologist in 1854 by Prof. Lewis Harper, and in 1857 another report was published. Both of these reports, particularly that of Professor Wailes, contain matter of much geologic and agricultural interest; but they are far inferior to the third report, published in 1860 by Dr. Eugene Hilgard, then State geologist. This is still the best available book on the geology of the State of Mississippi.

Doctor Hilgard's report, though printed in 1860 , was not generally distributed until 1866 , as the entire edition was sent to St. Louis for binding in November, 1860, and remained 
there until the close of the war. Doctor Hilgard's work on the geology and agriculture of the State had, however, deeply impressed its citizens. The following quotation from his history of the survey is of interest in this connection:

As a striking exemplification of the change wrought in public sentiment by the energetic prosecution of agricultural survey work, I may quote the action taken at the called session of the legislature of Mississippi in August, 1861. Under the terrible stress brought to bear on the State even then by the impending conflict, it would have been natural to expect the complete extinction of the appropriation for the survey work. Instead of this, ari act was passed suspending the appropriation for the geological survey " until the close of the war; and for twelve months'thereafter; except the sum of $\$ 1,250$ per annum, which shall be applied to the payment of the salary of the State geologist and the purchase of such chemicals as may be necessary to carry on the analysis of soils, minerals, and mineral waters, and to enable him to preserve the apparatus, analyses, and other property of the State connected with said survey." This appropriation was actually maintained during the entire struggle of the Confederacy; and so far as the vicissitudes of war permitted, the chemical work (and even some field work) was continued by me during the same time. The scarcity of salt suggested a utilization of some of the saline waters and efflorescences so comnion in the southern part of the State, and some forty (unpublished) analyses of such saline mixtures are on record. I made an official report on the subject to Governor Pettus, dated June 9, 1862. I also made a special exploration on the several limestone caves of the State, with a view to the discovery of nitrous earths; but from the fact that these caves are all traversed by lively streams, I found nowhere a sufficient accumulation of nitrates to render exploration useful.

Soon after the beginning of active hostilities in Tennessee, the university faculty having been dissolved, I was.detailed by the governor, as commander of the State militia, to take charge of the State property at the university during the war; and this, as well as a subsequent appointment by the Confederate authorities as an agent of the "niter bureau," prevented my being called into active service, except on the occasion, of the siege of Vicksburg, when, toward the end of that memorable epoch, I was ordered to erect "calcium lights" on the bluffs above the city, for the illumination of the Federal gunboats when attempting to run the gauntlet of the batteries. The difficulties of construction and procuring of the necessary materials delayed the completion of the arrangements, so that on the occasion of the final passage of the fleet no adequate light could be given. From a hospital at Jackson, where I was a patient at the time of its first capture, I soon af terwards made my way to my post at Oxford, where 1 remained on duty during the rest of the war. This duty was of tentimes a very arduous one, oxford being then within the "belt of desolation" between the two armies, which swept back and forth over it. "The survey collections had several very narrow escapes from destruction when the buildings were hastily occupied for hospital purposes; they were several times transferred on hospital cots from one building to another, but finally escaped without any material injury. Not so the collections at the capitol at Jackson, where the shelves and cases seem to have been swept with the butts of muskets, and the floor was strewn with broken specimens and shattered glass jars. About one-third of the collections stored there was entirely ruined, and of the remainder nearly all the labels were lost.

In 1866; as the period for which the survey appropriation was suspended had elapsed, work was again taken up by Doctor Hilgard. Several assistants aided him in this at different times, prominent among these younger men being Dr. Eugene A. Smith, now State geologist of Alabama. No further report was published by the State, however, and in 1872, during the days of reconstruction, the State auditor decided that the survey appropriation should not be paid. This arbitrary action, which could not be prevented under the circumstances then existing, put a final stop to the Geological and Agricultural Survey of the State:

Under, the energetic and capable administration of Doctor Hilgard it had accomplished much of direct practical benefit to the citizens of the State, while its purely scientific results were many and important.

In recent years considerable, work has been carried on in Mississippi by the United States Geological Survey, resulting in several reports on various phases of Mississippi geology and mineral resources, In, 1903 a limited cooperation was effected between the State and this Federal organization, Mr. R. H. Henry, World's Fair commissioner for Mississippi, having requested the aid of the United States Geological Survey in securing an adequate representation of Mississippi's mineral resources at the St. Louis exposition. The field work arranged for under this cooperative agreement was carried out in 1903 and 1904 by Mr. A. F. Crider, under the supervision of Mr. E. C. Eckel. The amount of time and money available for this field work was insufficient to provide for a detailed survey of the entire State. Attention was concentrated, therefore, on certain geologic formations which were directly of interest to Mississippians because of the mineral industries which might be based on them. 


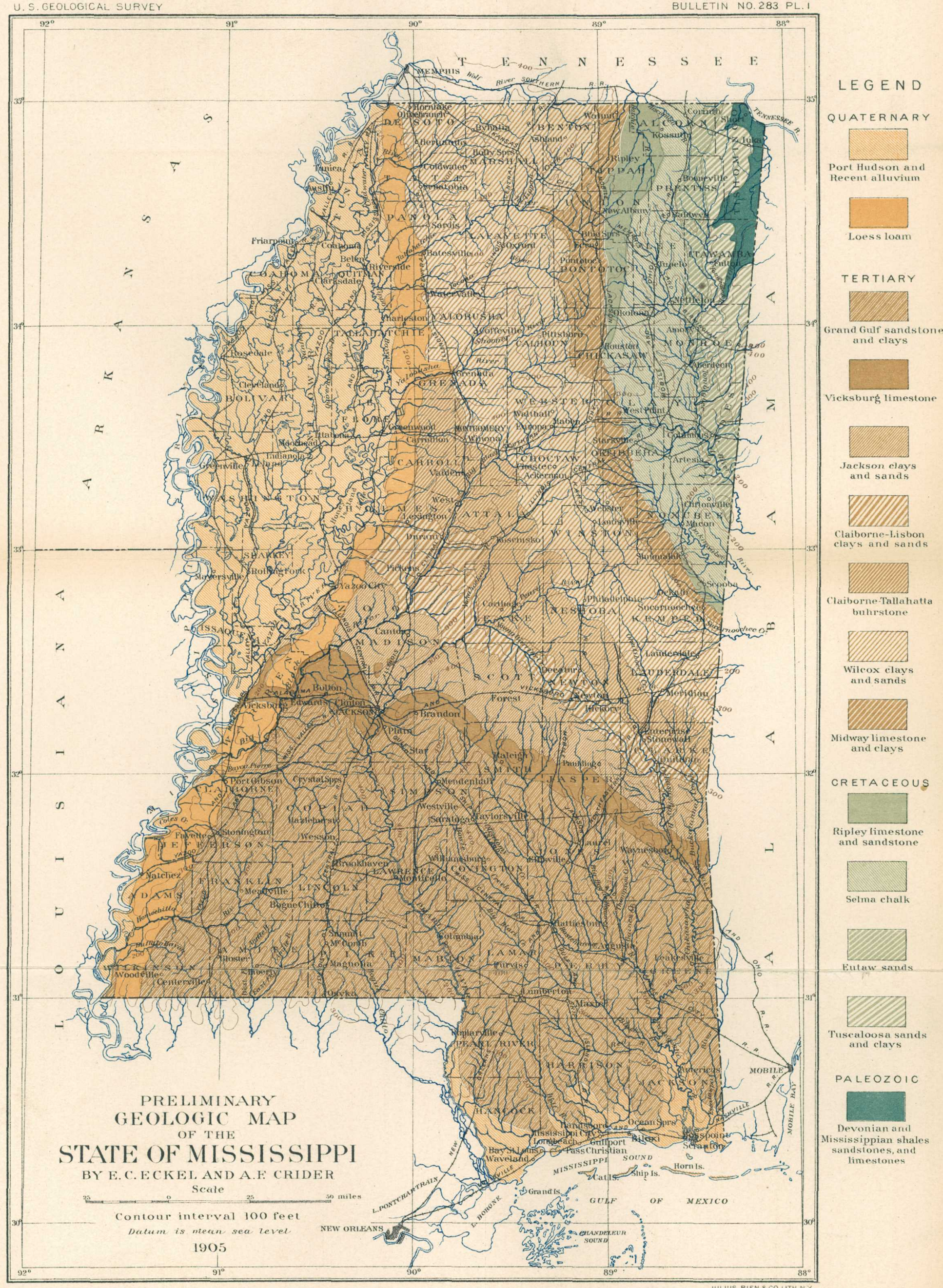




\section{GEOLOGY.}

Though the general geologic structure of Mississippi is very simple, the details of the stratigraphy are hard to make out, owing largely to the extent to which the underlying rocks are covered by the more recent deposits, such as the alluvial deposits and the "Orange sand," or Lafayette formation.

The oldest rocks in the State are a series of limestones and shales of Devonian and Carboniferous age, which outcrop in northeastern Mississippi, covering much of Tishomingo County and a small portion of Itawamba County.

The newer rocks outcrop south and west of this older mass, occupying successive roughly parallel bands, and all of these rocks dip slightly to the southwest, so that if the observer should start in Tishomingo County and travel through the State either to the south or west he would find himself continually passing over newer and newer series of rocks, until he finally reached the very recent alluvial deposits which fringe the Gulf and Mississippi River. The above conditions are shown in the cross sections (figs. 1 to 5 ).

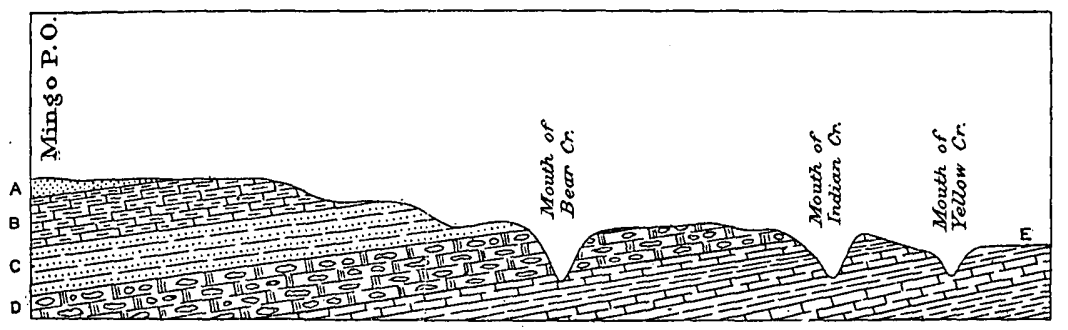

Fig. 1.-Cross section from mouth of Yellow, Creek to Mingo. A, Cretaceous; B, Chester; C, St. Louis; D, Tullahoma; E, Devonian.

The following table shows the geologic groups which are exposed in Mississippi, the newest formations being at the top of the table and the oldest at the bottom:

\section{Geologic formations of Mississippi.}

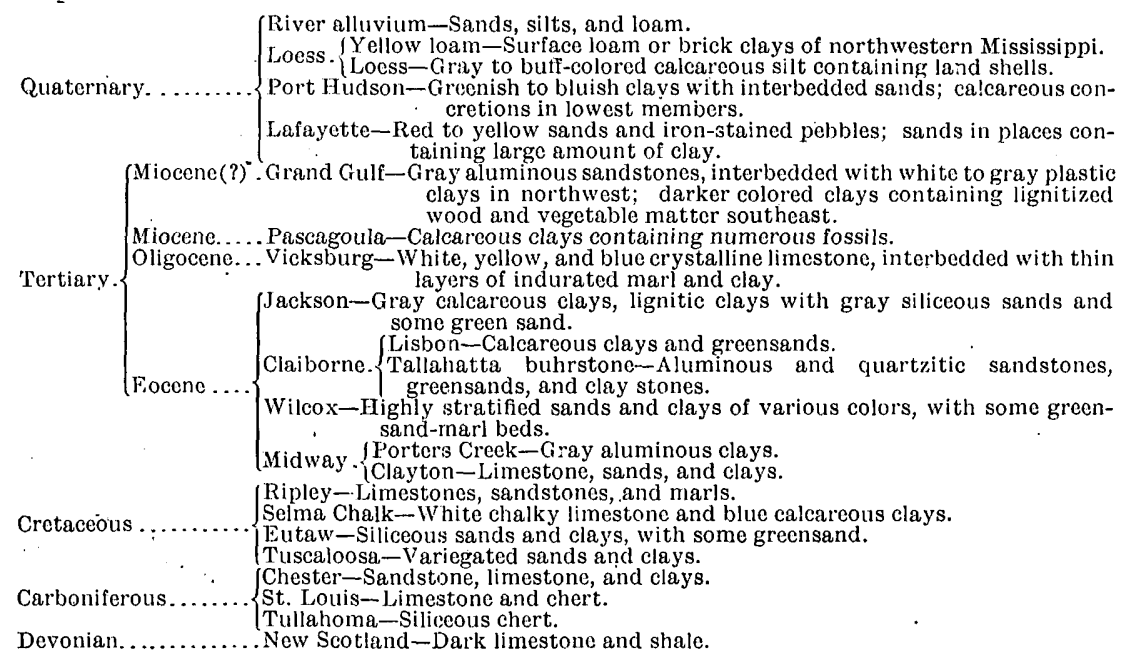

$\circ$

DEVONIAN.

Until recently the oldest rocks of Mississippi have been referred to the Lower Carboniferous, but a more thorough investigation has proved the presence of a fauna referred, by Charles Schuchert, now of Yale University, and E. M. Kindle, of the United States Geo- 
logical Survey, to the New Scotland beds (lower Devonian) of New York. These newly recognized beds outcrop along the west bank of Tennessee River and some of its smaller tributaries in northeastern Tishomingo County. The New Scotland fossils were first found along Yellow Creek, in secs. 15 and 22, T. 1 N., R. 10 E.

Yellow Creek rises southwest of Candler post-office, on the west side of Tishomingo County, flows in a general northerly direction, and empties into Tennessee River just north of the State line between Mississippi and Tennessee. Along its headwaters and middle course the stream flows over lower Cretaceous strata which overlap the older sea floor.

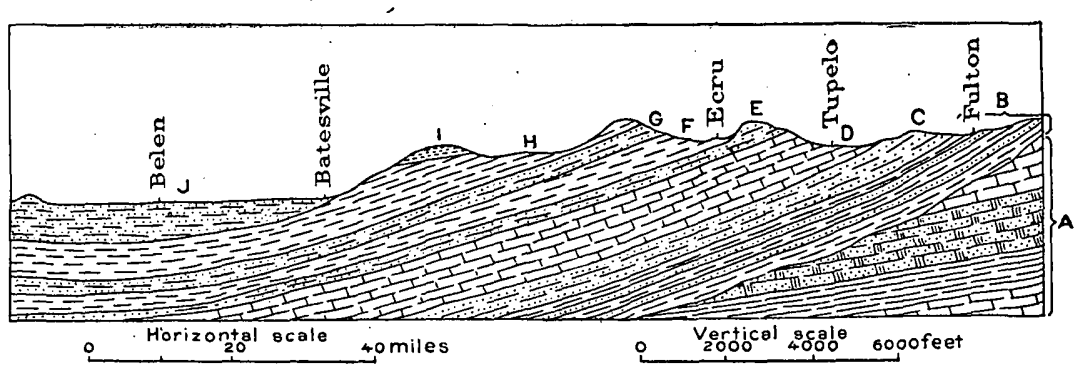

Fig. 2.-Cross section from Alabama to Mississippi River, in latitude of Tupelo.. J, Port Hudson; I, loess; H, Wilcox; G, Porters Creek; F, Clayton; E, Ripley; D, Selma; C, Eutaw; B, Tuscaloosa; A, Paleozoic.

At Doskie post-office, on the west side of R. 10 E., Yellow Creek first begins to cut into the older strata, and from this place to Tennessee River the older rocks occur at intervals in the bed of the creek. Along its lower course, in secs. 27,22, 15, and 14, the creek has channeled its bed into the hard limestone rocks, leaving perpendicular cliffs, in places more than 100 feet high. Above these cliffs are hills rising 150 feet higher and covered with Cretaceous and Lafayette deposits.

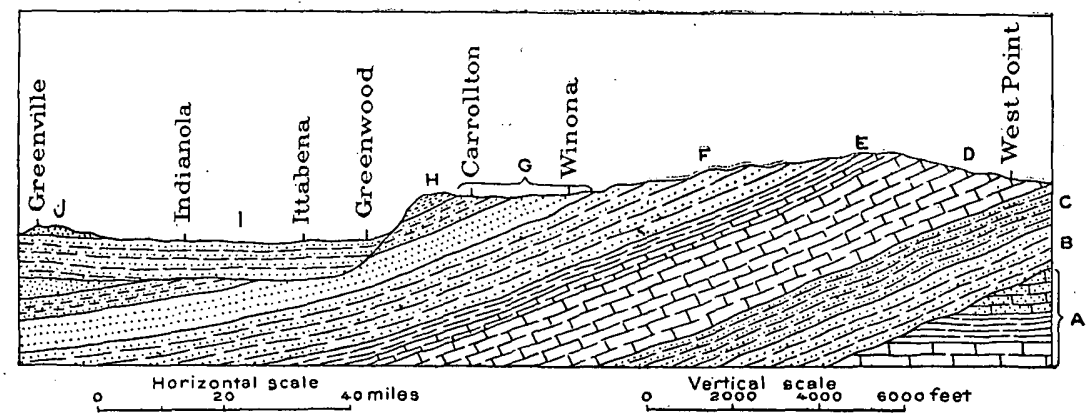

FIG. 3.-Cross section from West, Point to Greenville. J, river alluvium; I, Port Hudson; H, loess; G. Tallahatta; F, Wilcox; E, Midway; D, Selma; C, Eutaw; B, Tuscaloosa; A, Paleozoic.

The deep gorges of this region form a striking feature of the topography. The steepness of the slopes and the narrowness of the valleys indicate a rapid uplift which has caused the streams to erode the bottoms of their channels faster than the sides.

Below is given a section of the strata along Yellow Creek in sec. 22, T. 1 N., R. 10 E. At this place the creek is at present hugging the east bank-a cliff 140 feet high. There is a narrow bottom on the west side of the creek. the cliff on this side receding more gently than on the east. 
Section along Y ellow C'reek, in sec. 22, T. 1 N., R. 10 E.

Feet.

4. Thin-bedded, impure limestone at base, changing gradually to a bluish limestone at top of cliff.....95

3. Compact blue limestone, nonfossiliferous........................................... 40

2. Dark-gray limestone containing Tentaculites gyracanthus, Dalmanites cf. micrurus, Chonos-.. trophia sp.? Spirifer cyclopteris, Stropheodonta planulata, Leptæna rhomboidalis, Platyceras tenuiliratum, A noplotheca concava, Dalmanites pleuropter, Rhipidomella oblata, Meristella arcuata, A vicula cf. subequilatera, Stropheodonta beckei, Chonostrophia helderbergia.

1. Dark-colored, pure limestone containing Callopora cf. perelegans to water's edge..............

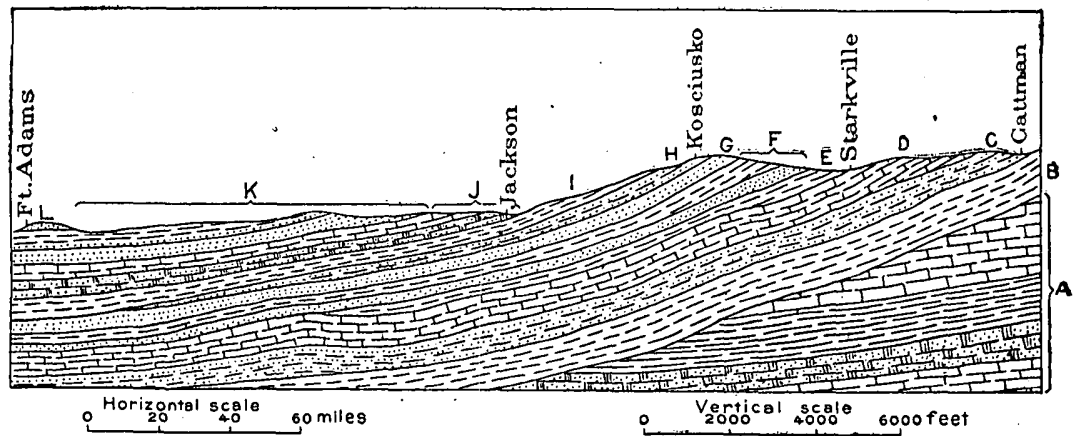

Fig. 4.-Section from Gattman to Fort Adams. L, loess; K, Grand Gulf (sandstone and clay); J, Vicksburg (limestons); I, Jackson (clays and marls); H, Claiborne; G, Tallahatta (sandstone); F, Wilcox (sands and clays); E, Midway (limestone and clays); D, Selma (limestone); C, Eutaw (sands and clays); B, Tuscaloosa (sands and clays); $A$, Paleozoic (limestone, etc.).

At the point where the public road crosses the creek in sec. 15, T. 1 N., R. 10 E., the dark-blue limestone occurs at the water's edge and extends to a height of about 50 feet. On the north side of the creek the contact between the dark-blue limestone and the thinner bedded shaly limestone passing into blue.shale is studded with the following fossils, which occur in a thin ledge of silicified chert: Orthothetes woolworthanus, Rhipidomella subcarinata, Proetus protuberans, and many of the forms found in the above list. Owing to the detritus which has covered the hillside it was impossible to determine the thickness of this fossilifer-

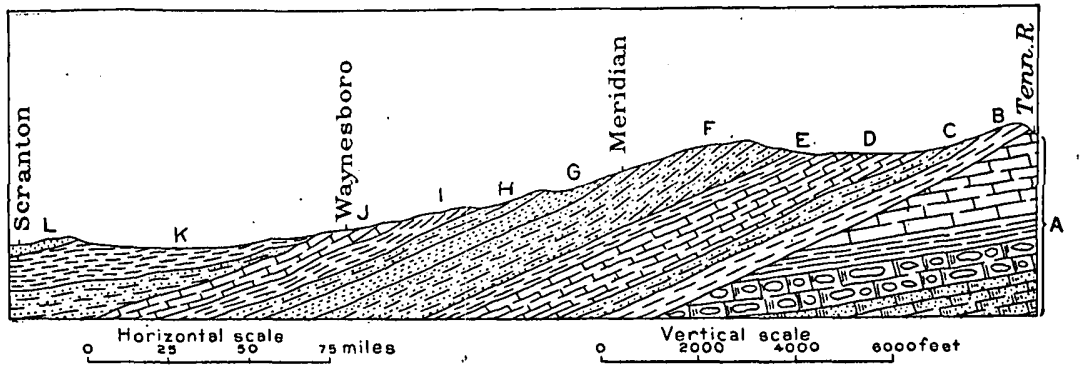

Fig. 5.-North-south cross section from Scranton to Tennessee River. L. Quaternary (silts); K, Grand Gulf; J, Vicksburg; I, Jackson; H, Claiborne; G, Tallahatta; F, Wilcox; E, Sucarnochee; D, Selma; C, Eutaw; B, Tuscaloosa; A, Paleozoic.

ous horizon, but it is measured in inches rather than in feet. The same dark-blue limestone is reported to form the cliff's on both sides of the stream from this point to the mouth.

In the northwest quarter of T. 2 N., R. 10 E., where the Iuka and Red Bluff Springs road crosses Yellow Creek, the limestone outcrops for one-half mile above the ford. At the "big rock" the limestone is horizontally bedded and when long exposed breaks down into thin shelly layers. It is a very compact, fine-grained, dark-blue rock, and, when freshly broken, gives a strong fetid odor. At about 30 feet above the creek at this point is a highly silicified bed of angular chert, or hornstone, destitute of fossils. 
Three-fourths of a mile north of the bridge at the old McMaster mill the dark-blue limestone is well exposed in the creek and road. At this place the overlying soil has been removed, leaving half an acre or more of the rock exposed. There are in the limestone two well-marked sets of joints. The main set extends $\mathrm{N} .25^{\circ} \mathrm{E}$. and a secondary set is practically at a right angle to the first. Overlying the dark-blue limestone are about 25 to 30 feet of angular flint and hornstone.

Along Whetstone Creek, which empties into Tennessee River east of Short post-office, the following section is shown:

Section on A. L. Bugg's land at mouth of Whetstone Creek, near Short.

Feet.

4. Angular chert, fint, and hornstone, devoid of fossils . . . . .

3. Dark-colored shale containing iron pyrite; very fossiliferous in lower part ................. 30

2. Dark-blue nonfossiliferous limestone, with well-marked joints trending N. $20^{\circ} \mathrm{E} \ldots \ldots \ldots \ldots \ldots 20$

1. Thin-bedded, fine-grained, shaly limestone, with thin bands of fine-grained sandstone or whet-

stone varying from a fraction of an inch to 12 inches in thickness . . . . . . . . . . . . . . . . . . . 20

No. 3 of this section perhaps represents the top of the Devonian. Unfortunately the fossils coming from this stratum were lost, so that the exact horizon can not at present be determined. The siliceous chert here and at McMaster's mill represents the lowest member of the Carboniferous and rests on the Devonian shale.

Farther south, near the mouth of Bear Creek, the siliceous chert bed continues to thicken, reaching a maximum thickness of. 150 . feet. Here the chert, as at Whetstone Creek, caps the tops of the hills. Still farther south along Bear Creek the St. Louis and Chester formations occur at a higher altitude. Fig. 1 (p. 7) shows the relations of the New. Scotland beds to the later formations. There is a very perceptible dip of the older rocks to the south.

A well section at the mouth of Bear Creek shows 160 feet of shaly, dark-colored limestone, 140 feet of dark-gray shale, and 450 feet of gray limestone. The gray. limestone is no doubt the equivalent of the gray limestone at the mouth of Yellow Creek, where the New Scotland fauna was collected. The well was begun in the limestone at the foot of the hill, the top of which is covered with siliceous chert.

\section{MISSISSIPPIAN (LOWER CARBONIFEROUS).}

Overlying the Devonian rocks is the Mississippian (Lower Carboniferous) series of cherts, limestones, sandstones, and shales. The thickness of these beds in Mississippi is not known, but is perhaps 800 or 900 feet. The beds are comparatively little disturbed, with a southward dip of about 40 feet per mile and a westward dip of about 20 feet per mile. The Carboniferous rocks represent the southwestern extremity of the southern Appalachian plateau, whose southern and western slopes are overlapped by the later formations.

\section{TOLLAHOMA FORMATION.}

The lowest formation of the Mississippian series consists of 130 to 150 feet of angular fragments of chert or flint which is correlated with the Tullahoma or Lauderdale chert of the Alabama survey. $a$ It is thickest near the mouth of Bear Creek and thins to the north.

The group in Alabama is described by McCalley as a siliceous chert, interbedded with argillaceous and calcareous shales, containing beds of limonite ore. The principal materials in Mississippi are highly siliceous fragmental chert, pulverized silica, and residual clay. In its unweathered condition the chert is stratified, but near the surface it occurs in angular fragments varying in size from sand grains to bowlders weighing tons. In places the chert has weathered into beds of snow-white or yellow pulverulent silica. Near the mouth of Bear Creek are large bodies of it which were mined for several years for an abrasive. Near the surface the silica of ten forms a white to yellowish clay or kaolin. A fine grade of china ware has been made from a deposit of this clay on Whetstone Creek. 
The Tullahoma chert is thinnest in the north. At the old McMaster mill it is represented by a thickness of 30 feet. Near the mouth of Whetstone Creek the formation has thickened to 100 feet, and at the mouth of Bear Creek, on the Alabama border, it has a thickness of 150 feet.

Along the headwaters of the small streams flowing into these larger streams the chert is always present and extends westward until it is covered by the later Cretaceous deposits. The southward extension is limited by the St. Louis limestone, which overlies the chert.

\section{ST. LOUIS LIMESTONE.}

Across the line in Alabama the St. Louis limestone has been recognized by McCalley $a$ along Tennessee River, where it is about 150 feet thick. The characteristic fossil Lithostrotion canadense has never been found in Mississippi, though a more thorough search may show its presence.

This formation in Mississippi consists of a series of dark-blue to gray limestones with more or less chert through it. - In places the limestone is quite fossiliferous. Many of the fossils were determined by Hilgard, but many of the names he used have now become antiquated. The St. Louis is distinguished from the Tullahoma by the fact that it has less chert and a greater amount of pure gray limestone.

In the upper part of the St. Louis there is a still lighter colored oolitic limestone containing Platycrinus huntsvillei. This no doubt is the equivalent of the Ste. Genevieve limestone of Missouri, southern Illinois, and western Kentucky. The aren of the Platycrinus limestone in Mississippi is linited, being confined to secs. 22, 26, and 27, T. 4 N., R. $11 \mathrm{E}$. On John Trammel's land, in sec. 22, T. 4 N., R. 11 E., the limestone is overlain by the heavybedded sandstone belonging to the Chester formation. The Carboniferous west of this locality is covered with the Cretaceous and Lafayette formations.

\section{CHESTER FORMATION}

istici.

The upper division of the Carboniferous in Mississippi is represented by a series of sandstones, limestones, and shales belonging to the Chester group. The lowest member of the Chester is a compact, coarse-grained sandstone which rests on the oolitic St. Louis limestone. The thicknesses of the various beds are not known, owing to the scarcity of exposures, which occur along the larger streams where the overlying Cretaceous has been removed.

The changeable character of the lowegr part of the formation is clearly shown at the steel bridge across Bear Creek near Mingo, where the following section may be seen:

Section at bridge across Bear Creek, near Mingo.

6. Top of hill covered with Lafayette.

Ft. In.

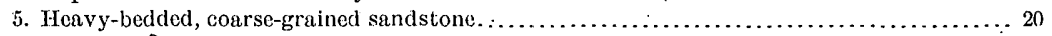

4. Fine-grained, dark-colored limestone giving rise to springs, with thin bands bearing Spirifer

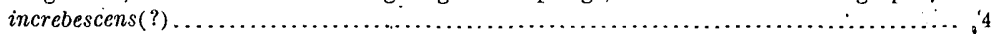

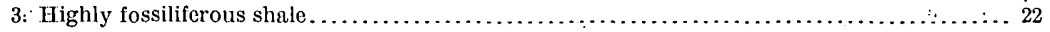

2. Coarse-grained limestone containing a large amount of iron oxide $\ldots \ldots \ldots \ldots \ldots \ldots \ldots \ldots \ldots, ., 6-8$

1. Dark-colored compact shale........................................... 10

The sandstone continues along the creek to the south and becomes coarser in texture. This sandstone represents the uppermost member of the Chester formation in Mississippi. Along Bear Creek it attains a thickness of at least 100 feet and perhaps much more. This creek along its middle course has channeled its bed deep into the sandstone, leaving high perpendicular cliffs standing on either side.

The area of outcrop of the Chester formation is confined chiefly to the stream valleys along Bear Creek and its tributaries in eastern Tishomingo County, along the headwaters of Tombigbee River in southegastern Prentiss County, and along Bull Miountain Creek in eastern Itawamba County. The southernmost outcrop in the State occurs along Bull Mountain Creek near the northern edge of Monroe County. The area between these streams is covered 
with the much later Cretaceous deposits, which conceal the Chester except where vigorous erosion has removed them.

The southernmost outcrop of the Chester limestone in Tishomingo County is at the old McDougle mill, on the headwaters of Mackys Creek.

No coal occurs in the Carboniferous rocks of Mississippi, as the Coal Measures do not outcrop within the limits of the State.

\section{CRETACEOUS.}

\section{TUSCALOOSA FORMATION.}

Between the uppermost member of the Carboniferous and the next overlying formation in northeastern Mississippi there is a marked unconformity. The overlapping formation, which is well shown near Tuscaloosa, Ala., has been called the Tuscaloosa.

In its lower part this formation is composed of dark-colored clays, thin seams of lignite, lignitic clays, and variegated sands and chert, and in the upper part of light-colored clays. The clays of the lower part are very compact, giving rise to numerous bold springs along the valleys where the clay has been cut into by the streams and is overlain by Lafayette sands and gravel. These clay horizons are often associated with beds of lignite and less pure clays which contain impressions of leaves and bits of lignitized wood. Where free from impurities the clay often forms a white to gray plastic material well adapted for making common jug ware. In places in Tishomingo and Itawamba counties the clay approaches a kaolin in appearance and purity and is used for making pottery.

Higher up in the formation the strata become more sandy in character, though there are more or less irregular beds of clay extending throughout the formation. The sands are irregularly bedded with a less amount of clay. It is impossible to trace any one horizon of sand or clay for any great distance. Along some of the larger streams, where good exposures are obtained, the material often changes within a hundred feet from a laminated clay to cross. bedded sands. There is more or less mica found throughout the formation in both the sands and clays.

The sands of the Tuscaloosa are, in places, of an Indian red color, and where they come into contact with the overlying Lafayette it often becomes impossible to separate the two formations. In other places the color changes from various shades of yellow to the many hues of red and purple. . The sands are highly cross-bedded, as shown in Pl. II, $B$.

The thickness of the formation in western Alabama is estimated at 1,000 feet. It thins perceptibly to the north. At Corinth, Miss., the hard Paleozoic rocks of the old sea floor were found in the city waterworks well at a depth of 450 feet, and the upper sands of the Tuscaloosa at 180 feet, thus making the entire thickness of the formation in northern Mississippi but 270 feet. Still farther north, in Tennessee, the entire thickness of the Tuscaloosa and the next overlying formation, the Eutaw, taken together and described under the name of Coffee sands, is given by L. C. Glenn as 300 feet.

The area occupied by this formation is a long, irregular band 5 to 15 miles wide, extending north from the Alabama line due east of Columbus to the Tennessee boundary, including the northeastern portion of Lowndes, the eastern half of Monroe, and a narrow strip along the eastern portion of Prentiss and Alcorn counties, and overlapping the Paleozoic rocks in Tishomingo and northern Itawamba counties. Tombigbee River approximately marks the western boundary north of Monroe County, and southward to the Alabama line the western boundary lies within 3 to 8 miles east of the river.

In northern Tishomingo County the character of the lower part of the formation is shown in a well on Bascom Whitehurst's farm on the west side of Yellow Creek, in T. 1 N., R. 10 E. The section of this well showed 10 feet of surface red clayey sand and gravel belonging to the Lafayette; 10 feet of yellow sandy clay; 10 feet of white clay, very pure; 14 feet of black lignitic clay containing wood, "charcoal," and a large amount of pyrite nodules. The well stopped in white clay at a depth of 65 feet before reaching the hard Paleozoic rocks, which outcrop at the foot of the hill about 100 feet below the top of the well.

The same dark-colored clay interbedded with white clay occurs on the Iuka and Mingo road at Crippledeer Creek. On the north side of the creek the following section is shown: 


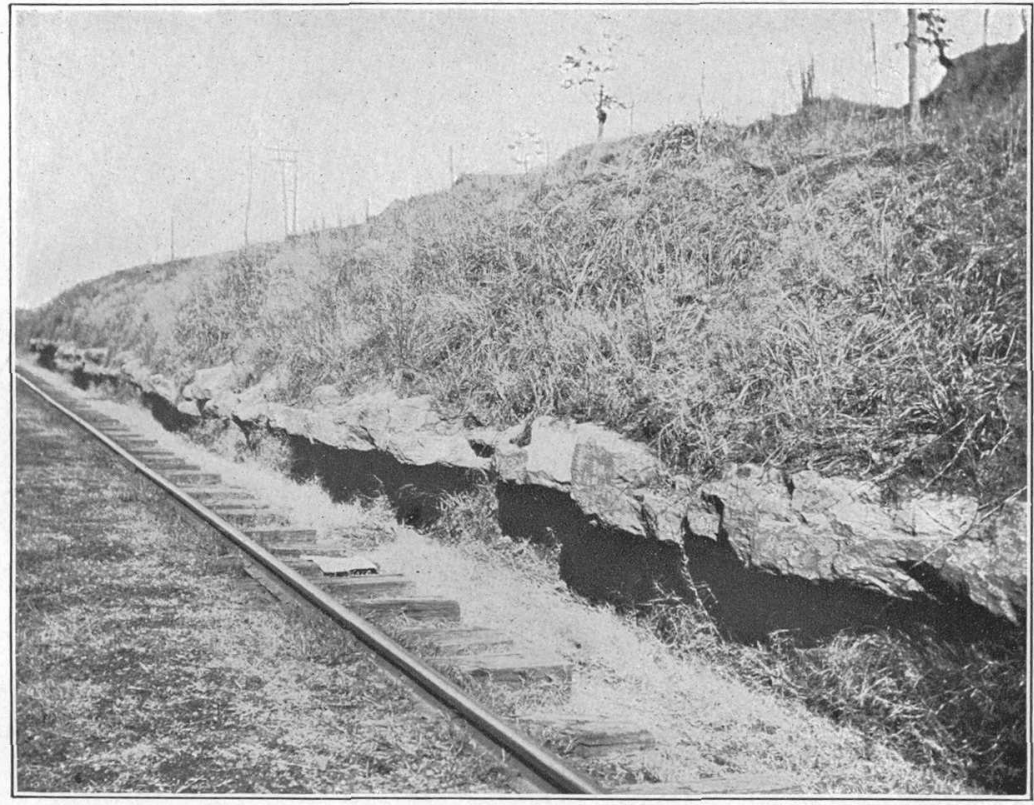

A. OUTCROP OF VICKSBURG LIMESTONE AT ROCK CUT 1 MILE WEST OF CLINTON.

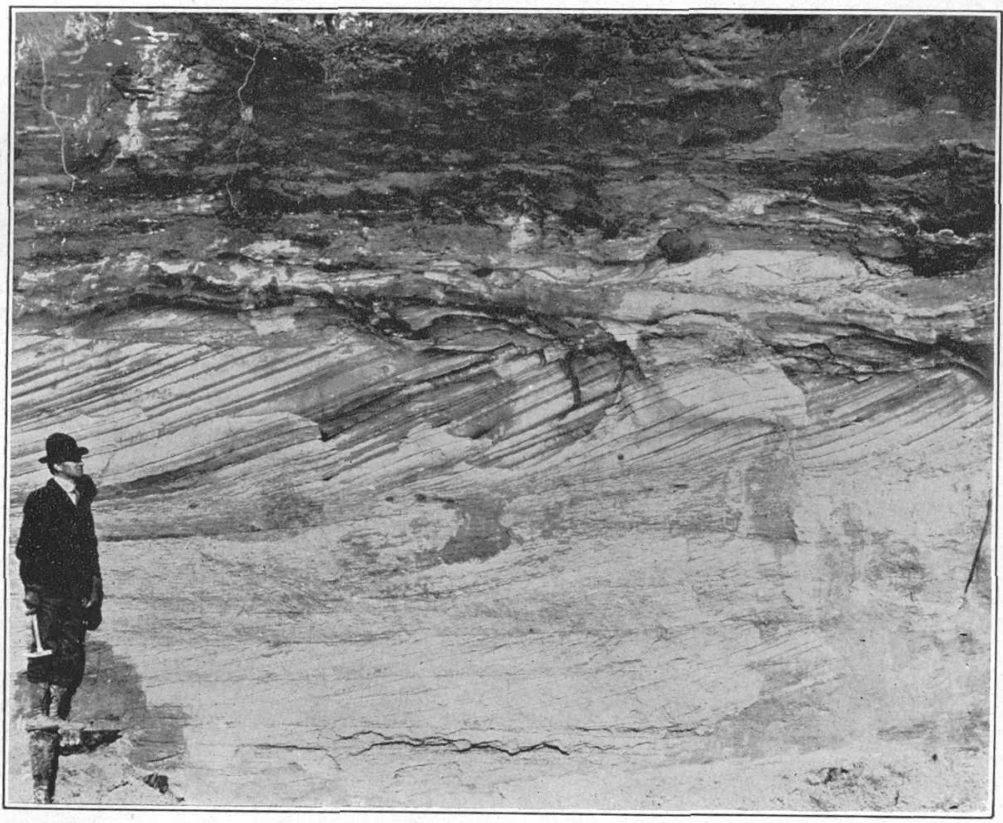

B. TUSCALOOSA SANDS NEAR IUKA. 
Section on north side of Crippledeer Creek.

Feet.

4. Lafayette sand of deep Indian-red color, containing a large amount of clay $\ldots \ldots \ldots \ldots \ldots \ldots \ldots .4$

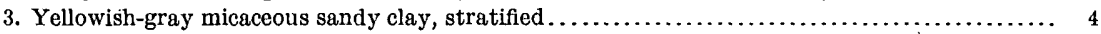

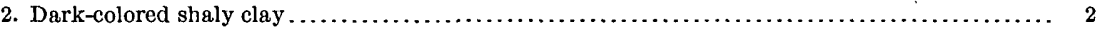

1. Clay containing small pebbles of quartz; has been used for making jug ware $\ldots \ldots \ldots \ldots \ldots \ldots .6$

The hill on the south side of the creek shows 50 feet or more of dark lignitic clay which is at a higher elevation than the white clay on the north side. The Paleozoic rocks outcrop in the creek a short distance to the east and are no doubt present at the foot of the hill at this place, but are covered with the wash from the hills.

To the west of the eastern border of the Tuscaloosa, in Tishomingo County, the dark-colored clay which comes at the base of the formation gradually disappears and the lighter colored clay and sand become more prevalent. In places beds of pure white clay, comparatively free from sand, are reported to be 30 feet thick.

Farther south, in Itawamba County, somewhat different conditions prevail. In the northeastern part of the county, in the vicinity of Rara Avis, beds of gravel occur in the lower Tuscaloosa, along Bull Mountain Creek and its tributaries. A well at Amory, which is 249 feet above tide, obtained an artesian flow in sand and coarse gravel at a depth of 190 feet. This is overlain by 180 feet of pink clay and soapstone. An 8-foot bed of white gravel $a$ overlying a stratum of black, fetid lignitic clay is reported to have been found at a depth of 217 to 220 feet in wells at Aberdeen at an altitude of 203 feet above sea level. The character of the gravel and the depth below the surface place these beds in the Tuscaloosa.

There is a difference in the gravel of the Lafayette and that of the Tuscaloosa. The latter is much less waterworn and occurs in angular fragments of various sizes from sand to large bowlders. On the whole there is but a small percentage of waterworn pebbles, and these have no regular shape, being usually angular fragments with the corners somewhat smoothed or rounded. These gravels bear Paleozoic fossils. The Lafayette gravel contains a larger proportion of quartz pebbles, which are oblong or egg-shaped and have evidently been transported over a greater distance.

The gravel beds of the Tuscaloosa no doubt occur farther north in Tishomingo County, but where these beds come into contact with the Tullahoma beds of angular residual chert it has not been possible in the limited time given to this region to make any distinction between them. It would seem plausible, however, that the angular chert beds found near the mouth of Bear Creek and containing rounded waterworn pebbles should be placed in the Tuscaloosa and not in the Tullahoma.

At various localities south and east of Fulton, Itawamba County, beds of pure lignite have been mistaken for bituminous coal. This is interbedded with sandy, lignitic, and highly micacenus clays. In places it overlies a white pottery clay of exceptional purity. Just above the bed of lignite is a thin ferruginous sandstone. The descending waters bearing iron oxide were checked by the impervious lignite and cemented the sand into a compact hard rock. There are many large springs in central Itawamba County, at this horizon. The lignite occurs on J. A. Hood's land, in sec. 11, T. 10 N., R. 9 E.; on G. W. Edwards's land, in sec. 18, T. 10 N., R. 9 E.; on Mr. Dulaney's land, in sec. 9 , T. 9 N., R. 9 E.; also on M. L. Reed's land at Tilden. At the latter place it is 20 inches thick and when freshly dug from the bank is of a jet-black color.

The Tuscaloosa clays of southeastern Itawamba County have been utilized for years in making stoneware. These clays are of a bluish and in places pinkish color, and are interbedded with sandstone and less pure clays. The clay used by the Davidson pottery comes just above a ledge of sandstone which is but a few inches thick.

\section{EUTAW SANDS}

Immediately overlying the Tuscaloosa and underlying the Selma chalk is the Eutaw formation, which is typically exposed at Eutaw, Ala. Hilgard described the upper part of this formation under the name of Tombigbee sands. 
The characteristic material of the Eutaw consists of fine-grained micaceous sands, calcareous in the upper part, with more or less glauconite or greensand. Irregular beds of sandy clays are not infrequent. The lowest division is largely composed of highly cross-bedded sands of various colors, such as orange, red, blue, and deep yellow. This lower part is distinguished with difficulty from the upper Tuscaloosa, and the line between the two formations is therefore arbitrarily drawn.

The irregularity in the deposition of the lower Eutaw is well marked along upper Tombigbee River and its tributaries and also along the streams in Alabama. No one stratum of sand or clay can be traced continuously for any great distance. A bed of clay 8 or 10 feet thick may thin out in as many rods and entirely disappear.

A well at Eutaw, Ala., reached the clays of the Tuscaloosa formation at a depth of 400 feet. The wells at Columbus, Miss., obtain water below the first clay of the Tuscaloosa at a depth of about 300 feet. Columbus is located on the western edge of the Eutaw formation and the wells therefore pass through its entire thickness, which here is less than 300 feet. At the northern border of the State the formation is much thinner. The combined thickness of the Eutaw and the underlying Tuscaloosa at Corinth, Miss., is less than 375 feet, while in western Alabama it is 900 to 1,000 feet. At Corinth the top of the Eutaw was reached at a depth of about 90 feet and the hard Paleozoic rocks at 450 feet. If the two formations thin proportionally the Eutaw here would be about 90 feet and the Tuscalonsa 270 feet thick. A record of the well was kept, but the driller failed to notice any change in passing from the Eutaw to the Tuscaloosa.

The area occupied by the Eutaw consists of a narrow band of territory 5 to 12 miles wide, lying just east of Tombigbee River in Monroe and Lowndes counties, and on the west side of the river north of this, extending through eastern Lee, east-central Prentiss, and eastern Alcorn counties.

The change from the sandy Eutaw formation to the overlying Selma chalk is not an abrupt stratigraphic break. On the contrary, there is a gradual change from the upper members of the Eutaw to the lower division of the Selma. It is so gradual that experienced well drillers often fail to distinguish the line of contact between the two formations. The upper Eutaw contains a large amount of carbonate of lime, greensand, and a fauna greatly resembling that of the Selma chalk.

The section given below offers an excellent opportunity for studying the transition beds between the Selma and Eutaw. At a distance of 4 miles above Columbus, on Tombigbee River, the bluff on the west side reaches about the same height as the hill on which Columbus is built. For a distance of 1 mile along the river the cliff exposes a fine section of the upper Eutaw and the basal beds of the Selma. West of the river the Selma prairies slope gently to the top of the bluff and then suddenly descend 40 to 50 feet to the water's edge. The east side of the river is a level bottom but little above the river. At the town of Columbus there are high bluffs on the east side and a wide bottom on the west side of the river. The same black prairie soils of the Selma, which come within 3 miles of the river due west of Columbus, extend to the high bluff along the river 4 miles above town. The following section was obtained in the bluff where the dirt road comes down to the river:

11. Lafayette.

Section on Tombigbee River 4 miles north of Columbus.

10. White to gray joint clay of the Selma, containing less sand at the top than at the bottom. In the unweathered condition the clay is of a pale-blue color, containing green and black Ft.In.

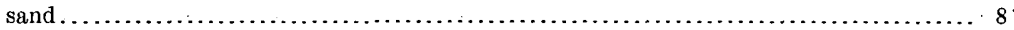

9. Greensand, unconsolidated, highly calcareous, and containing numerous large oyster shells : 5

8. Ledge of indurated greensand, calcareous, with large oyster shells. This ledge, being harder than the stratum above, stands out more distinctly and from a distance looks very much like a hard, compact ledge of limestone ..................................... 12

7. Lighter colored unconsolidated sand containing a few very small fossils and no large ones... $\quad 1 \quad 2$

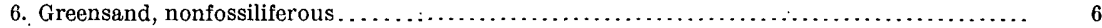

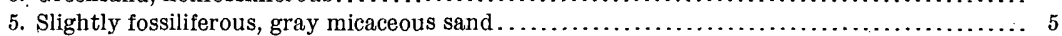

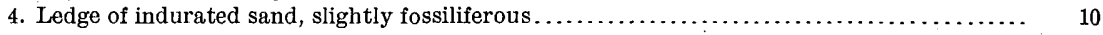

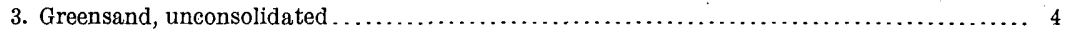

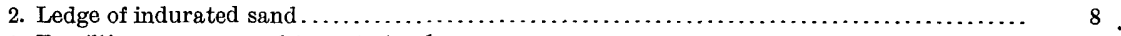

1. Fossiliferous greensand to water's edge ....................................... 4 
The material at the water's edge is identical with the greensand in the bluff above the bridge at Columbus and belongs to the Eutaw formation. The upper part of the bluff represents the "blue rock" of the Selma. A deep gully a few yards to the north has a continuous section of the Selma from the top of the Eutaw to the Selma prairie soil. The contact between the Eutaw and Selma is therefore shown in the section given above. Nos. 1 to 9 , inclusive, mark the sandy phase of the Eutaw, and No. 10 the clayey portion of the Selma, containing more or less sand.

The above section is at or near the locality mentioned by Hilgard in his Geology and Agriculture of Mississippi, page 74, where many fossils were collected by Dr. William Spillman, of Columbus, from the upper part of the "Tombigbee sand." A list of the fossils as identified by Spillman is published in the report just cited, page 389. According to this list the fauna is somewhat closely related to that of the overlying Selma and Ripley formations, many of the species cited ranging to the top of the Ripley, but at least one of the ammonite species belongs to a generic type that is not known above the horizon of the Eutaw. There seems to be a gradual transition, both lithologically and faunally, from the upper calcareous sands of the Eutaw to the lower division of the Selma.

The underlying larger portion of the Eutaw has yielded very few fossils other than lignitized wood, but at a few places in Alabama species of Exogyra, Ostrea; Anomia, Placenticera, etc., have been found.

The line of contact between the Eutaw and the overlying Selma at the Alabama line is near Tombigbee River, which practically forms the boundary between the two formations south of Columbus. Near the mouth of James Creek, in the northeast corner of Noxubee County, the greensands of the upper Eutaw are exposed at intervals for 2 miles or more along Tombigbee River. James Creek has cut its channel into these greensand beds. The east bank of the Tombigbee also shows a 10-foot section of the same greensand beds, which here contain a large amount of clay.

The following section on the Southern Railway $3 \frac{1}{3}$ miles east of Corinth shows the contact between the upper Eutaw and the Selma chalk:

\section{Section on Southern Railway $3 \frac{1}{3}$ miles, east of Corinth.}

Feet.

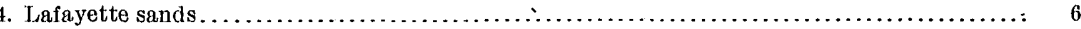

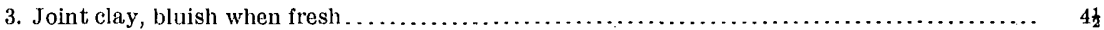

2. Green calcareous sand, very fossiliferous, thinning to the east $\ldots \ldots \ldots \ldots \ldots \ldots \ldots \ldots \ldots \ldots \ldots$

1. Yellow calcareous coarse-grained saind, with thin ledge of indurated sandstone.......... 8

In the branch to the west the coarse greensands of the Selma are present at a lower elevation than No. 1 of the above section. The strata here dip to the east, or in an opposite direction to the general dip of the district. The base of the greensand stratum, No. 2, at the west end of the cut is 4 feet above the railroad track. At a distance of 800 feet to the east the top of this stratum has dipped below track level.

The country to the east of the Eutaw-Selma contact is hilly; that to the west is rolling or level. The western edge of the Eutaw can be traced southwest from the above section by a line of hills which form a sharp contrast to the level or rolling country of the Selma prairies to the west.

Three miles south of Corinth in a deep cut on the Mobile and Ohio Railroad the following section, which is very similar to the one given above, is exposed:

Section on Mobile and Ohio Railroad 3 miles south of Corinth.

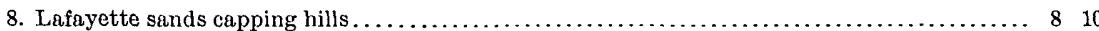

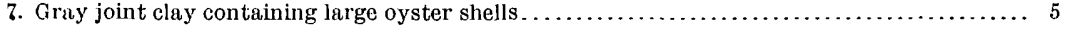

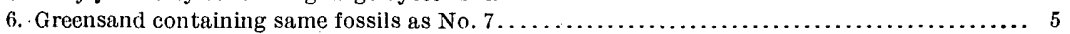

5. Indurated calcareous sand, yellow at bottom and passing into deep-yellow, coarse, sharp-

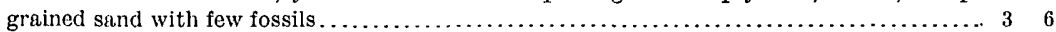

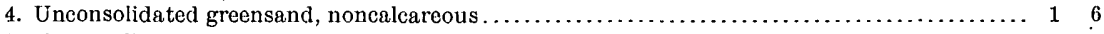

3. Unconsolidated yellow sand, noncalcareous. . . . . . . . . . . . . .

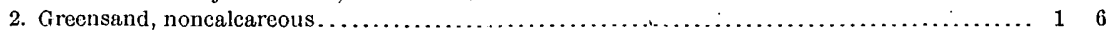

1. Pale greensand, becoming a deeper green at bottom of cut. In the branch below this sand

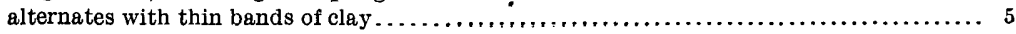


The following interesting and instructive section of the Corinth waterworks well was obtained from the waterworks company:

\section{Record of waterworks well, Corinth.}

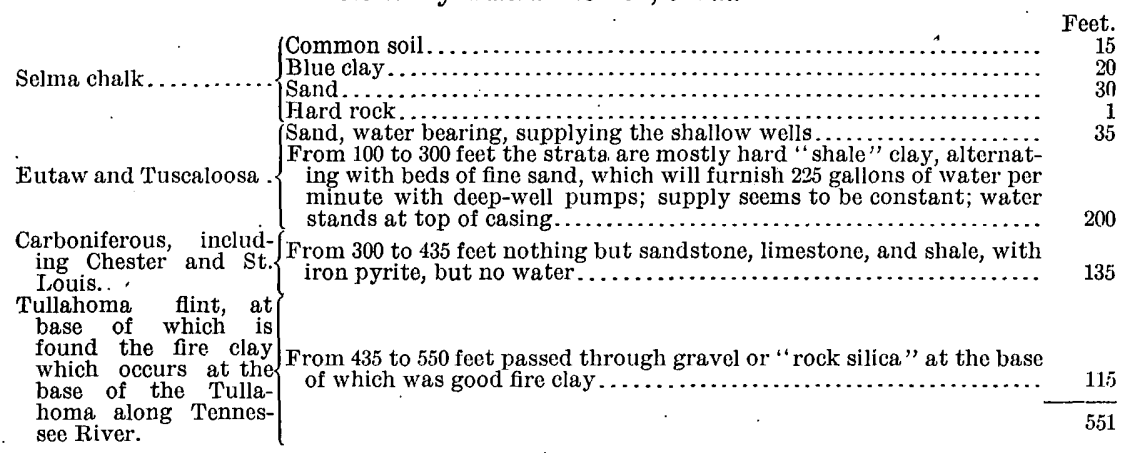

The well stopped in the fire-clay bed at the base of the Tullahoma. This section gives the most accurate and reliable data obtainable on the thicknesses of the different formations.

There is a decided thinning of all the formations from south to north. The Selma, which Smith has estimated to be 930 to 1,200 feet thick in western Alabama, has thinned to 100 feet at Corinth. The Tuscaloosa and Eute w taken together have a thickness in the Corinth well of only 200 feet, while Smith has estefrnated the Tuscaloosa alone to be 900 to 1,000 feet thick in western Alabama.

\section{SELMA CHALK.}

The subdivision of the Cretaceous immediately overlying the Eutaw formation is the Selma chalk. It was called "Rotten limestone" by Hilgard, but the name has since been discarded for that of the locality where it is typically exposed-Selma, Ala.-this name being first used by Dr. E. A. Smith of the Alabama Geological Survey.

The Selma chalk is a mass of loosely semicemented lime carbonate of exceptional purity, and where typically exposed along the larger streams it has a white appearance and is called the "white chalk" bluffs. To the casual observer the entire formation has much the same appearance, but it may be separated into three natural divisions, based primarily on chemical analysis-(a) the sandy transition beds at the base, (b) the "blue rock," or more clayey unweathered portion, and (c) the "rotten limestone," or chalk, including the upper portion of the formation.

(a) The lowest division contains a large amount of free sand which was washed into the Selma sea from the Eutaw and older land surface to the east. This forms the transition beds from the extremely sandy portion of the Eutaw to the deep-sea deposits of lime carbonate which characterize the Selma chalk. The amount of sand is greatest near the base and becomes less and less upward until it finally disappears entirely.

(b) The middle portion contains a large amount of clay and when freshly dug is of a bluish color. It is found in the deep wells and is known and recognized by the drillers as "blue rock." The great amount of clay in the lime carbonate renders the rock impervious to water. The fine supply of artesian water stored in the Eutaw reservoir is held in place by the "blue rock" of the Selma. It is on account, therefore, of this impervious bed overlying the Eutaw that so many artesian.wells are available over the Selma area.

(c) The uppermost division contains a greater amount of lime carbonate and much less clay than the "blue rock" and likewise a smaller amount of free silica than the lowest division. Some of the analyses of this chalk show 98 per cent calcium carbonate.

In places a hard crystalline limestone, somewhat silicified, forms a capping to some of the hills of the upper Selma. Hard flint rock and thin strata of sandstone are reported in the deep-well boring at Livingston, Ala. 
Fossils are more or less abundant throughout the formation. Ostrea, Gryphra, and Exogyra are almost always present, and numerous other forms occur in the upper and lower subdivisions. Below is a list of the Selma fossils reported from Mississippi by Dr. T. W. Stanton. In speaking of these fossils Stanton remarks:

The list of fossils from the Selma or "Rotten limestone" is based on a small collection from Starkville received from you and a somewhat larger collection obtained by myself at Houston. Both these localities are comparatively near the contact of the Selma with the Eocene in an area where the Ripley as such does not appear. From this fact and from the close resemblance of the faunas, which would apparently be more striking if the condition of the fossils would permit the identification of all the species present, I am inclined to believe that the so-called "Rotten limestone" of these localities is really equivalent to a part of the Ripley farther north. Hilgard a mentions similar occurrences in Noxubee and Kemper counties.

It is very probable that thorough systematjc collecting in the Selma would show some distinctive species. The rare fossils mentioned by Hilgard as Radiolites and "Ichtyosarculites" and several of tho genera of fishes and other vertebrates have not been reported from the Ripley, but their presence is probably due to the difference in physical conditions rather than to difference in age. It will be noticed that a few of the invertebrates in the following list do not appear in the Ripley list, but nearly all of these species are elsewhere found in the Ripley.

\section{Fossils from the Selma chalk at Houston and Starkville.}

Hemiaster.

Terebratulina.

Ostrea larva Lamarck.

Ostrea vomer Morton.

Exogyra costata Say.

Gryphæa vesicularis Lamarck.

Anomia argentaria Morton.

Plicatula saffordi Conrad.

Dianchora echinata (Morton).

Pecten quinquecostata Sowerby?

Pecten venustus Morton.

Lima acutilineata Conrad.

Lithophagus ripleyanus Gabb.

Nemodon eufalensis (Gabb).

Cucullæa vulgaris Morton.

Nucula perequalis Conrad.

Leda longifrons Conrad.

Trigonia thoracica Morton.

Crassatella.

Cardium.

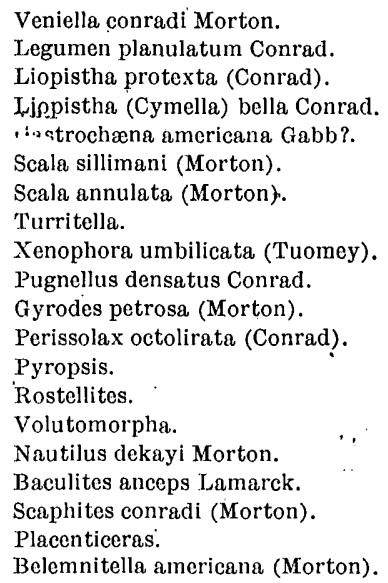

The thickness of the Selma as determined by many deep-well borings throughout the region is found to vary from 350 feet near the Tennessee line to 1,000 feet at Starkville and to over 1,200 feet just across the State line in Alabama.

The area of the outcropping Selma is a level or rolling prairie, well adapted to agriculture. It is everywhere marked by a rich black prairie soil, which is readily formed from the underlying limestone. It embraces the large part of Noxubee, western Lowndes, eastern Oktibbeha, the larger part of Clay, western Monroe, eastern half of Chickasaw, almost all of Lee, western Prentiss, and central Alcorn counties. The west line of outcrop can be traced approximately through Scooba, Flatwood, and a point 3 miles west of Starkville to Houston. From this place the line bends more to the east, passing through Troy, Blue Springs, Graham, Antioch, and a point 2 miles west of Kossuth to the Tennessee line.

A description of the contact between the lower Selma and the underlying Utah, as shown in the river bluff 4 miles above Columbus, is given under the Eutaw formation (p. 14). At the above-mentioned place the ledges of indurated greensand carrying Eutaw fossils gradually change to the blue argillaceous joint clay of the Selma. A short distance west of the river the typical black prairie soils of the Selma come to the surface. 
At the big oxbow bend in Oaknoxubee River, one-fourth mile below the wagon bridge at Macon, the river has formed on its south side a bluff 75 feet high (PI. III, $A$ ). This bluff shows a solid mass of white or slightly yellow limestone, nonfossiliferous and apparently without bedding planes, but in a view from a distance the stratification of the material is apparent from the fact that the unequal hardness of the strata has caused some to weather more rapidly than others. There is a marked dip to the south. This same limestone outcrops in all the smaller streams flowing into the Oaknoxubee from Macon to the Alabama border. It is a part of the upper subdivision of the Selma. Still farther west the prairies and hillsides from which the soil has been removed are covered with large oyster shells which have given rise to the term "shell land."

There is a striking difference in the character of the general topography and vegetation of the Selma chalk and the overlying Porters Creek clays. The cold; gray, and apparently lifeless soils of the Porters Creek produce a growth of short-leaf pine which does not appear on the black calcareous soils of the Selma. In some of the abandoned fields of the Selma, where there is a thin veneering of Lafayette, there is more or less pine, particularly along the edges of the Selma, but pine is not native to these soils. Black, white, and post oak, with some hickory, poplar, gum, and walnut, are the principal timbers of this formation.

On the west side of Quilby Creek, where it runs south along the State line between Alabama and Mississippi, 7 miles east of Sucarnochee, Miss., the Selma chalk forms a small bluff. The prairie soil extends back 2 miles farther west and is overlain by the Porters Creek clay. On the east side of the creek, about 100 yards east of the Alabama line, the Selma forms a bluff somewhat higher than on the opposite side in Mississippi. The top of the bluff is capped by a coarse-grained sandstone, cemented by lime carbonate, and this doubtless represents the lowest member of the Ripley, which is present in Alabama but wedges out in southeastern Mississippi. The sandstone contains large, round lime concretions the size of the closed hand.

Three miles north of Scooba the western border of the Selma chalk outcrop is seen in a series of hills forming the south bank of Wahalak Creek. The bottom of the creek here is about $1 \frac{1}{2}$ miles wide, with the steeper slope on the south side. The creek has channeled its bed into the white Selma chalk, which outcrops continuously throughout its course. The limestone occurs in the bed of the creek to a point $6 \frac{1}{2}$ or 7 miles northwest of Wahalak, but the overlying Porters Creek clay is present on the higher land on both sides of the creek.

On the low range of hills south of Wahalak Creek, beginning near the Mobile and Ohio Railroad track and extending eastward, is a bed of sand rock 10 feet thick capping the tops of the hills. It is a coarse-grained sandstone cemented with lime carbonate and contains numerous little bivalve shells. It is similar to sandstone found 7 miles east of Sucarnochee and doubtless represents the lowest beds of the Ripley formation.

In the vicinity of Prairie Rock there is a hard crystalline limestone, or "flint rock," very different from the soft chalk-like limestone along the river at Macon. This so-called "flint rock" has been used for road metal and foundations for houses, but the readiness with which it breaks down under the action of weathering agents renders it unsuitable for such purposes.

Men familiar with the districts say that the hard flinty limestone is rarely more than 4 feet thick, and always occurs near the surface. Below this hard stratum comes the soft, whiter "rotten limestone," which is, on an average, 20 feet thick and is underlain by the "blue rock." Cisterns are always dug to the "blue rock," which requires no curbing.

There are two distinct soils in the Selma area, giving rise respectively to " the post-oak "land and the "prairie" proper. The former is the highest land between the stream divides, which has suffered but little erosion. It is a very level table-land, sloping gently to the streams. This post-oak land is covered with a thin veneering of Lafayette loam, rarely more than 10 feet thick. It has a growth of post oak and some scrubby black-oak timber. The "prairie" land is that from which the Lafayette has been removed, so that the rich 


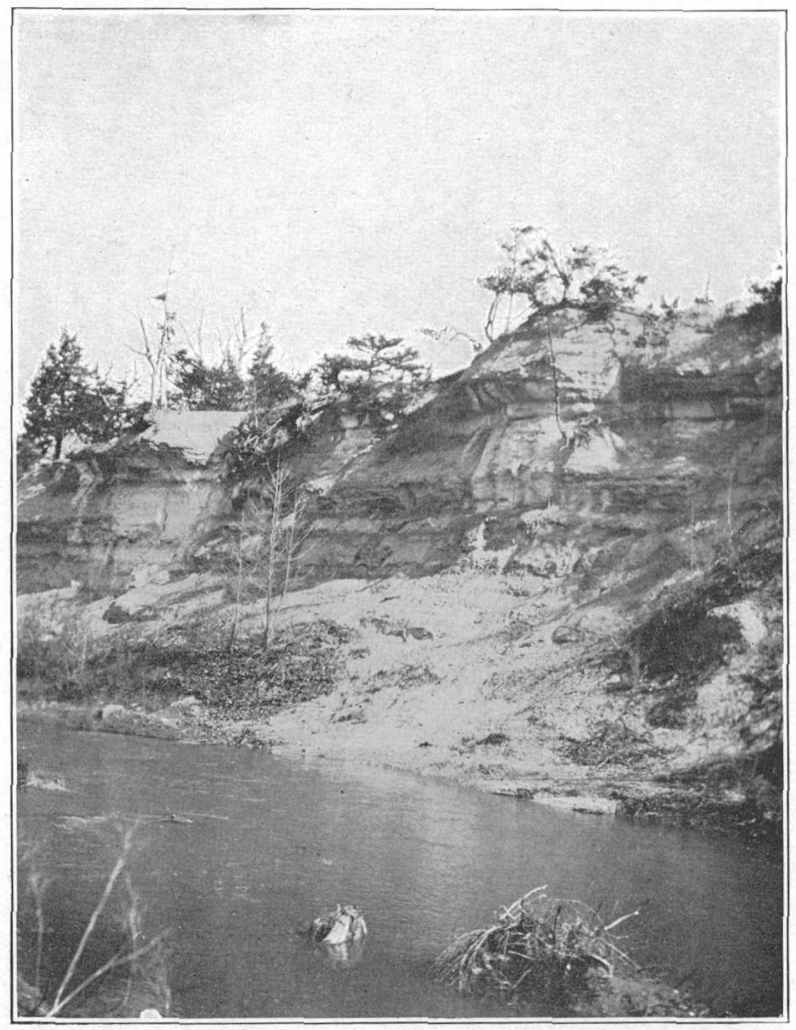

A. SELMA CHALK BLUFF, MACON.

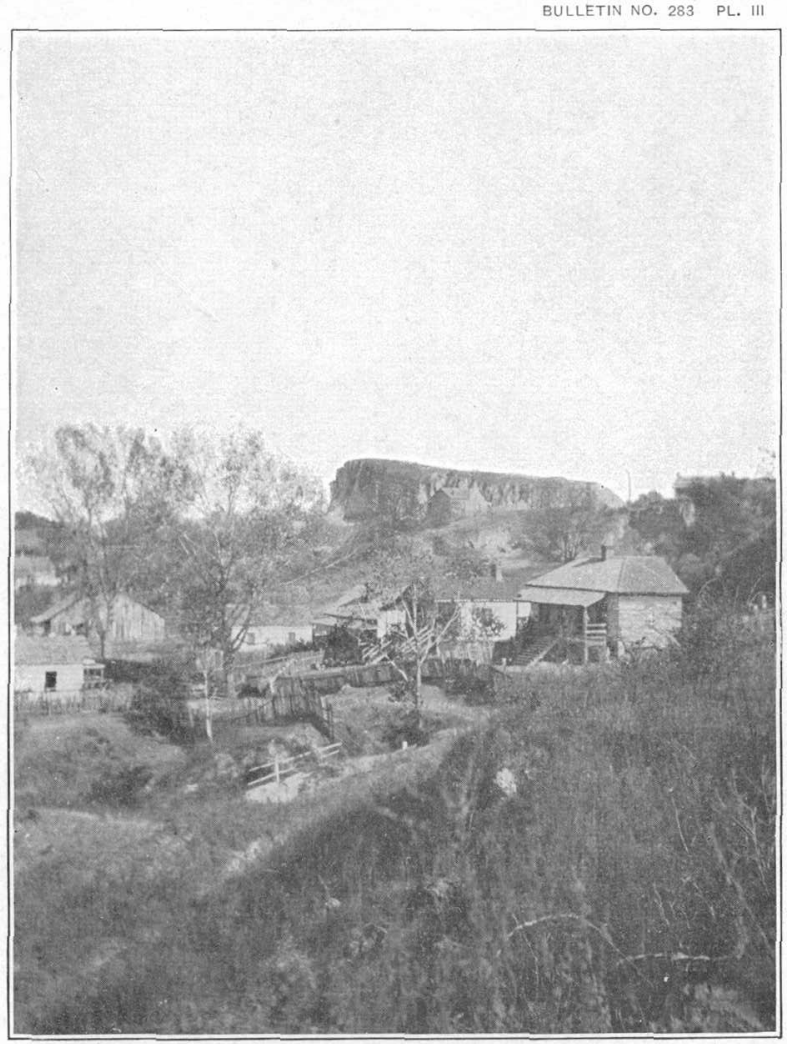

B. LOESS BLUfF, yaZOO CITY. 
black loam, formed from the decomposition of the Selma chalk, is at the surface. 'This land lies along the slopes or more rolling areas where erosion has been more rapid.

When the country was first settled the black prairie soil was too strong for cotton. It produced a large stalk, but little lint. .Until recent years all the cotton was planted on the poorer post-oak soils and the prairie lands were put in corn. After years of continuous crops of corn the prairie lands became the best cotton lands and now the principal part of the cotton is planted on these richer soils. In fact, the thinner post-oak soils in places have been abandoned for cultivation and are used only for pasturage.

At Cliftonville, in northeastern Noxubee County, there is a thin stratum 4 to 6 feet thick of hard crystalline limestone similar to that at Prairie Rock. It forms a mesa-like capping to the hills in this vicinity. It is locally known as "lime rock," in distinction from the "blue rock" below.

The blue rock of northeastern Noxubee County is the lower subdivision of the Selma. It is very rich in lime carbonate and breaks down into a black, easily cultivated, fertile soil which produces more cotton and corn to the acre than any other land of the State. The higher interstream areas to the west are covered with the post-oak clay soil.

The sands of the Eutaw formation extend 2 miles west of Aberdeen and the post-oak clay soils of the Selma chalk continue westward nearly to the main line of the Mobile and Ohio Railroad. Over a large area in central Monroe County the Selma rarely appears at the: surface, but is always found in wells and cisterns and along the railroad excavations: One: mile south of Strongs the Illinois Central Railroad has cut into the Selma to a depth of 15 feet.

The width of the Selma area is greatest in Monroe and Chickasaw counties, in the latitude. of Houston. From this locality northward the outcrop becomes narrower and the formation thinner. Wells near Rienzi, Corinth, and Wenasoga, Miss., and Chewalla, Tenn., show a gradual thinning of the Selma to the north, and it finally disappears completely near Camden, Tenn.

\section{RIPLEY FORMATION.}

Immediately above the: Selma chalk comes the uppermost division of the Cretaceous, which has been called Ripley, from its typical exposure near. Ripley, Miss. The materials composing this formation are alternating beds of coarse-grained sandstones, limestones, clays, unconsolidated sands, phosphatic greensands, and marls. The deep, quiet sea in which the great thickness of the homogeneous Selma limestone was deposited became more changeable at the beginning of Ripley time. The character of the Ripley deposits marks the transition period from the deep, marine deposits of the Selma to the shallow, nearshore deposits of the early Tertiary, in which the predominating materials are sand and clays.

The thickness of the formation, estimated from the width of outcrop, with a westward dip of 15 feet per mile, reaches a maximum of 280 feet.

There is a marked change in topography from the rolling prairies of the Selma to the steep hills of the Ripley. The area of the latter is much smaller than that of the Selma. It is widest at the north in Tippah County, gradually narrowing to the south, and wedging out altogether at Houston, Chickasaw County. To the south the Ripley is well marked in Alabama, but wedges out in Kemper County, Miss., near Shuqualak. Between this town and Houston the Ripley in most places is absent, and when present occurs as outliers.

Prof. W. N. Logan, of the Agricultural and Mechanical College of Mississippi, in his Geology of Oktibbeha County, page 30, describes three outliers of phosphatic greensand and. bluish and yellowish micaceous marl which he refers to the Ripley. 'Exogyra costata;' Ostrea falcata, Gryphiea convexa, Pecten quinquecostatus, and Placuna scabra are found in the marls. Doubtless more detailed work in the various counties along the western border of the Selma area would reveal a large number of similar Ripley outcrops.

The Ripley beds in Mississippi have not received sufficient study and detailed work to determine accurately the relative succession of strata. At New Albany and Ecru, which are located along the western edge of the formation in Union and Pontotoc counties, there 
are some well records which show the succession of strata of the upper and middle portions of the formation. The well at New Albany doubtless reaches the water-bearing sand near the base of the formation. The following is the record of this well, as given by the driller, Mr. Baker:

Record of well at New Albany.

Feet.

Surface clay 20

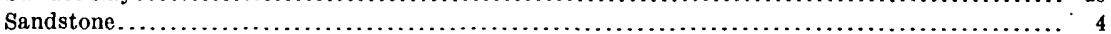

Clayey sand, water bearing. . . . .

Blue marl containing shells, with occasional beds of limestone 3 to 4 feet thick $\ldots \ldots \ldots \ldots \ldots \ldots \ldots \ldots$

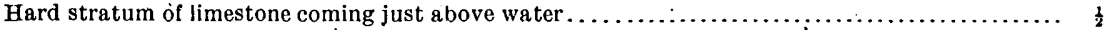

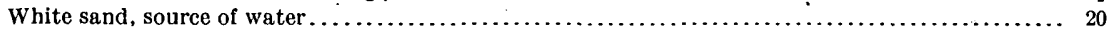

The following accurate log was kept of the railroad well at Ecru, Pontotoc County, by the driller, Albert Goldsbury:

Record of well at Ecru.

Feet.

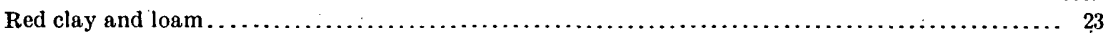

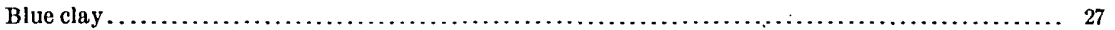

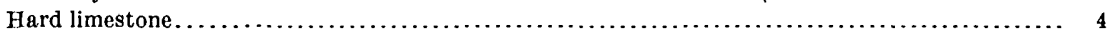

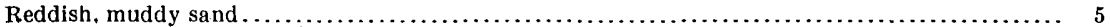

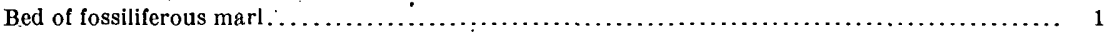

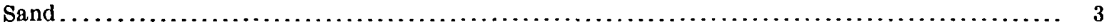

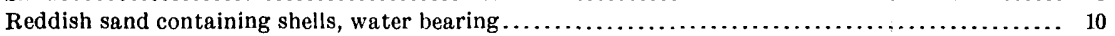

Compact clay, bottom of well.

One-half mile west of Ecru, on the west bank of the creek, is a hard ledge of limestone, but slightly fossiliferous, which is underlain by a softer limestone of a white to gray color. Three miles west of town, on Clay Lemon's place, occurs a coarse-grained sandstone which belongs to the upper Midway group.

The classic locality for the Ripley formation is in the "bluffs of Owl Creek, 3 miles northeast of the town of Ripley," $a$ Tippah County. The locality one-half mile south of town, on the south side of Ripley Creek, was referred to the Ripley formation by Hilgard and so mapped; but a more thorough study of the fossils by Harris and others has placed the persistent hard limestone teeming with Turritella mortoni in the lowest member of the Midway, of Tertiary age. This Turritella rock, in the vicinity of Ripley and along many of the streams for 3 miles east, overlies the "Owl Creek" marl, which is of undoubted Ripley age.

The same order of strata as found east of Ripley continues northward into Tennessee. At. Chalybeate Spring, $2 \frac{1}{2}$ miles east of Walnut, the upper member of the Cretaceous, the Owl Creek marl, is overlain by the Turritella rock of the Midway. This marl is dark blue and micaceous, und contains in places remarkably well-preserved fossils.

A list of the Ripley fauna is given below. The collection was made and the fossils determined by Dr. T. W. Stanton. In speaking of the Ripley fauna, Stanton adds:

The Ripley list is based on collections obtained by myself in Tippah County, Miss, in 1889. The most thorough collecting was done along the Owl Creek bluff about 3 miles from Ripley, where the original Ripley fauna described by Conrad was obtained. It must be considered the type locality for the Rip ey formation and it ylelded fully 90 per cent of all the species here listed. The collection contains a considerable number of undescribed or unidentified species which are not mentioned in the list. Many synonyms and doubtiul forms are also omitted. 


\section{Ripley fossils from Tippah County.}

Cassidulus subquadratus Conrad.

Cassidulus subconicus Clark.

Hamulus onyx Morton.

Ostrea tecticosta Gabb.

Ostrea plumosa Morton.

Ostrea subspatulata Forbes.

Exogyra costata Say.

Anomia argentaria Morton.

Lima acutilineata Conrad.

Lima reticulata Forbes.

Pecten quinquenarius Conrad.

- Camptonectes argillensis Conrad.

Camptonectes parvus Whitfield:

Syncyclonema simplica Conrad.

Syncyclonema conradi (Whitfield).

Gervilliopsis ensiformis (Conrad).

Inoceramus argenteus Conrad.

Inoceramus cripsi var. barabini Morton.

Inoceramus sagensis $O$ wen.

Inoceramus proximus Tuomey.

Pulvinites argentea Conrad.

Dreissena tippana Conrad.

Crenella serica Conrad.

Pinna laqueata Conrad. .

Cucullæa vulgaris Morton.

Nemodon eufalensis (Gabb).

Nemodon brevifrons Conrad.

Pectunculus subaustralis d'Orbigny.

Nucula cuneifrons Conrad.

Nucula percrassa Conrad.

Nucula slackiana Gabb.

Leda longifrons Conrad.

Leda pinnaformis Gabb.

Leda protexta Gabb.

Trigonia angulicosta Gabb.

Trigonia eufalensis Gabb.

Trigonia thoracica Morton.

Vetericardia crenalirata Conrad.

Crassatella vadosa Morton.

Crassatelia pteropsis Conrad.

Cardium alabamense Gabb.

Cardium dumosum Conrad.

Cardium tippanum Conrad.

Cardium eufaulense Conrad.

Pachycardium spillmani Conrad.

Veniella conradi Morton.

Cyprimeria depressa Conrad.

Cyprimeria alta Conrad.

Aphrodina tippana Conrad.

Tenea pinguis Conrad.

Enona eufaulensis Conrad.

Tellimera eborea Conrad.

\author{
Linearia metastriata Conrad. \\ Gari elliptica Gabb. \\ Solyma lineolata Conrad. \\ Legumen planulatum (Conrad). \\ Leptosolen biplicata Conrad. \\ Panopæa decisa Conrad. \\ Pholadomya occidentalis Morton. \\ Anatimya anteradiata Conrad. \\ - Anatimya postsulcata Conrad. \\ Liopistha protexta (Conrad). \\ Veleda lintea Conrad. \\ Cuspidaria moreauensis (Meek and Hayden)? \\ Corbula crassiplica Gabb. \\ Corbula perbrevis Conrad. \\ Corbula subcompressa Gabb? \\ Gastrochæna americana Gabb. \\ Pholas cithara Morton. \\ Diploconcha cretacea Conrad. \\ Dentalium ripleyanum Gabb. \\ Scala sillimani (Morton). \\ Turritella vertebroides Morton. \\ Turritella tippana Conrad. \\ Turritella trilira Conrad. \\ Laxispira lumbricalis Gabb. \\ Trichotropis cancellaria Conrad. \\ Lunatia obliquata Hall and Meek. \\ Gyrodes crenata Conrad. \\ Gyrodes petrosa Morton. \\ Anchura abrupta Conrad \\ Anchura rostrata (Gabb). \\ Anchura decemlirata Conrad. \\ Pterocerella típpana (Conrad). \\ Pugnellus densatus Conrad. \\ Pyrifusus bellaliratus Conrad. \\ Pyrifusus subdensatus Conrad. \\ Fusus holmesianus Gabb. \\ Fusus tippanus Conirad. \\ Strepsidura interrupta (Conrad). \\ Perissolax octolirata (Conrad). \\ Pyropsis perlata Conrad. \\ Liopeplum cretaceum (Conrad). \\ Liopeplum canalis (Conrad). \\ Liopeplum subjugosum (Gabb). \\ Liopeplum leidermum (Conrad). \\ Volutomorpha eufalensis (Conrad). \\ Rostellites navarroensis (Shumard). \\ Nautilus dekayi Morton. \\ Baculites ovatus Say \\ Baculites anceps Lamarck. \\ Scaphites conradi Morton. \\ Turrilites alternatus Tuomey. \\ Sphenodiscus lenticularis (Owen).
}

The character of the lower Ripley is shown in the hills near Ellistown. These hills, bordering on the Selma chalk area, rise 150 feet or more above the prairie lands to the east. The following section shows the succession of strata on the Ellistown and Ripley road in sec. 21, T. 7 S., R. 4 E., in eastern Union County:

Section of Ripley formation near Ellistown.

4. Lafayette capping top of hills.

Feet.

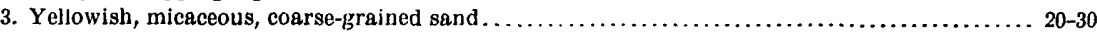

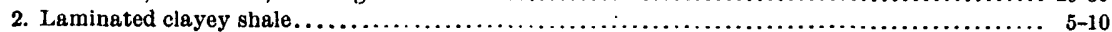

1. Limestone ledge of unknown thickness. 
This limestone is sufficiently pure for making lime, and is used locally for building purposes. The strata below the ledge of limestone are covered with the wash of the hillside, and the thickness can not be determined.

South of Ellistown the blue calcareous clay which perhaps belongs to the Selma appears up the hillside 25 feet above the bottom land to the east.

\section{TERTIARY.}

\section{MIDWAY GROUP.}

\section{CLAYTON FORMATION}

The lowest division of the Tertiary is represented in Mississippi by a series of hard crystalline limestones and calcareous sandy marls, belonging to the Clayton. The limestone of this formation was referred by Hilgard to the Ripley. More recent inyestigation, however, by Harris, Aldrich, and others has, on paleontologic grounds, placed the limestone in the lowest division of the Tertiary.

The Clayton formation in Mississippi is represented by about 30 to 40 feet of limestone and 30 feet of sandy marl. . Owing to the limited area of the Clayton and the lack of detailed work across the State it has been mapped with the overlying Porters Creek clay, which is shown as a narrow belt extending from Alabama to Tennessee and lying between the Ripley and Selma on the east and the Wilcox on the west. The name Midway is given to the group from the type locality at Midway, Ala.

The Clayton is well shown in Tippah and Union counties, where it has received the most detailed study. Its lowest member is a hard blue limestone containing a large number of fossils, the most prominent of which is Turritella mortoni. For this reason this rock has been called the Turritella limestone. On Mr. Bobo's place, $1 \frac{1}{2}$ miles north of Chalybeate, the Turritella rock is little more than a conglomerate of angular fragments of gray, white, and yellow limestone cemented together. Turritella fossils make up a large part of the limestone. Throughout the whole mass are small, rounded, and often glazed iron pebbles reaching one-fourth inch in diameter. This limestone rests on the dark-blue "Owl Creek" marl of the Ripley and is overlain by a yellow sandy marl. The hard persistent Turritella rock is found in numerous branches in the vicinity of Chalybeate and southward to Ripley. Two and a half miles east of Ripley it forms in places small bluffs along the strearis.

The Clayton limestone outcrops on the south side of Ripley Creek one-half mile south of Ripley. The same ledge occurs along the creek for 1 mile or more to the east. It is here underlain by a yellow, highly micaceous, arenaceous marl containing a few badly preserved fossils. The yellow color is due to oxidation by surface agencies, for a few feet below the surface the color becomes a dark blue.

One-half mile east of the bridge across Ripley Creek south of town the Turritella limestone of the Clayton forms a bluff 20 to 40 feet high. The following section gives the relation of the materials immediately overlying the Turritella rock:

\section{Section of Clayton formation near Ripley.}

4. Lafayette capping hill.

3. Thin stratum of green calcareous sandstone, very hard and containing large flakes of mica and few fossils . . . . . . .

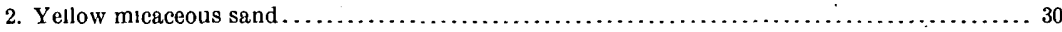

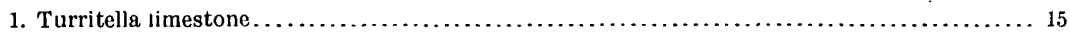

No. 1 of the above section is found in the wells at Ripley from 10 to 35 feet below the surface. At the mill in the bottom on the east side of town a well recently dug has the dark-blue "Owl Creek" marl on the dump. The yellow sand overlying the Turritella rock is very persistent and is easily distinguished from the overlying Lafayette where the latter is present. When damp the yellow sand has a slight greenish tinge. This sand is present along many of the streets of Ripley, especially on the lower streets near the depot. In the northern part of the town, near the "city limit," the greenish-yellow sand outcrops on 
Main street and in the gullies east of the street. Here the same relations exist as at the hill one-half mile east of the bridge mentioned above.

The thin ledge of hard green calcareous sandstone on top, of the yellow sand has more the appearance of a limestone. Its thickness is 24 to 26 inches.

Two and a half miles east of Ripley, on the Ripley and Boonville road, the Clayton limestone occurs in a deep ravine, as shown in the following section. Some distance down the creek the "Owl Creek" marl occurs at a lower elevation.

\section{Section of Clayton limestone 21 $\frac{1}{2}$ miles east of Ripley.}

Ft. In.

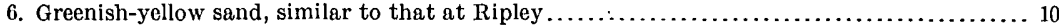

5. Upper stratum of hard limestone with large Turritella fossils ............................. 1

4. Yellow to gray marl containing numerous large Turritella ............................ 20

3. Hard flinty limestone with no Turritella, but containing a small branching coral ................ 26

2. Indurated marl containing large Turritella........................................ 12

1. Lowest stratum visible is the Turritella rock. which here is made up almost entirely of these fossils........,

The same Turritella limestone that is found $2 \frac{1}{2}$ miles east of Ripley shows in many ravines east of Muddy Creek in the vicinity of Chalybeate. At a few places, as at Chalybeate Spring, the underlying Ripley marl is exposed. The limestone occurs as ledges from 3 to 6 feet thick. On Mr. Bobo's place, $1 \frac{1}{2}$ miles north of Chalybeate, the limestone is overlain by about 30 feet of yellow sandy marl containing numerous fragile fossils. At the top of the yellow sandy marl is a thin band of green sandstone containing mica. The order of strata here is the same as it is at Ripley, and the materials are but little different in general lithologic character.

The most complete list of fossils from the Midway group in Mississippi is given by G. D. Harris in American Paleontology, No. 4, pages 22-25.

\section{PORTERS CREEK CLAY.}

This formation was described by Doctor Hilgard in his Geology and Agriculture of Mississippi under the term Flatwoods clays. It is known in Alabama as the Black Bluff or Sucarnochee series, and was described by Safford of Tennessee as Porters Creek. The term Porters Creek as used by Safford has priority of date and has therefore been adopted by the United States Geological Survey.

The Porters Creek clay is traceable across western Kentucky, Tennessee, and Mississippi, and as far east as Alabama River in Alabama.

The area in Mississippi is a narrow belt from 2 to 15 miles wide, extending across northeastern Kemper, southwestern and western Noxubee, northeastern $\cdot$ Winston, western Oktibbeha, Clay, and Chickasaw, west-central Pontotoc and Union, and western Tippah counties. The typical "illatwoods" is characterized throughout the State by low, flat land resembling the broad bottom of a large river. In many places the country is still uncleared and is everywhere known as the "Flatwoods country."

The material of the Porters Creek formation in the lower part is principally a dark-gray joint clay, overlain by a coarse-grained micaceous sandstone containing large fossils. Occasionally it weathers almost white; and in places it is a black slaty clay, bearing fossils. $a$ In places the clay contains bodies of micaceous sandstone that seem to have been segregated into horizontal sheets and vertical masses, many of which have the appearance of small dikes. It is quite possible that small fissures have been made in the clay by. earthquakes and subsequently filled with micaceous sand.

Hilgard $b$ in describing the physical properties of the Porters Creek or "Flatwoods" clays, says:

This Flatwoods clay does not "readily dissolve" or form a plastic paste with water; but whenever by dint of repeated kneading (such as the wheels of vehicles will perform) it has been made to form a paste, its tenacity is such as to be scarcely exceeded by the most approved "prairie mud." Nor can the black 
prairies of Pontotoc and Monroe, during the wet season, present more formidable obstacles to the wagoner than do the bottoms and hillsides of the Flatwoods region. Hence the great frequency among its streams of such names as Mud Creek and others still more eloquently expressive of the awe in which they are held by those who are habitually obliged to traverse the Flatwoods.

"There are" no wells to the writer's knowledge, which have been dug through the Porters Creek, nor any rivers crossing at a right angle to the strike of the: formation, by which to determine its thickness. Estimated from the width of outcrop, with a westward dip of 15 feet to the mile and a maximum width of outcrop of 14 miles, the thickness, is 210 feet. The more probable thickness, as observed from surface outcrops in Tippah County, is about 100 feet.

On the road leading northwest from Ripley the gray Porters Creek clay is present to the top of the hill $1 \frac{1}{1}$ miles northwest of town, also $2 \frac{1}{2}$ miles north of town and at various places along the railroad between Ripley and Walnut. Its thickness, as measured on the bill northwest of Ripley, is 75 feet.

One-half mile north of Walnut the gray; lead-colored clay, which at Ripley rests on the thin band of sandstone and is 34 feet above the top of the Turritella rock, outcrops in the deep ravine south of the railroad water tank. The same clay outcrop continues along the track one-half mile north of the water tank.

West of Walnut the hills rise 100 feet or more above the lowlands along the streams. On some of the hillsides the surface soil has been removed by heavy rains, and a more complete section of the Lower Eocene strata is exposed. One mile west-southwest of Walnut the same gray, lead-colored clay as that in Ripley and at the water tank north of Walnut shows on the steep hillside just south of a little stream flowing eastward, to a height of 40 feet above the stream.

About 3 miles south-southwest of Walnut, on the farm of John Wright, a hill 50 feet above the stream contains numerous ledges of gray sandstone. At the foot of the hill; in Mr. Wright's yard, the sandstone is soft, resembling the rotten claystone of the Tallahatta buhrstone in Newton County, described on page 29. The ledges near the top of the hill are very hard and contain large casts of fossils. The fossils collected from this locality were referred to Dr. W. H. Dall and were said to be Eocene, but no closer determination was made. The rock is a very coarse-grained sandstone, containing more or less greensand and mica. This sandstone overlies the gray clay referred to above.

The same sandstone occurs on the high hills northeast of Tiplersville, where it is also underlain by gray clay. $a$

From the above data the following section, which shows the relations of the Eocene of Tippah County overlying the Cretaceous, may be given:

\section{Generalized section of the Midway group in Tippah County.}

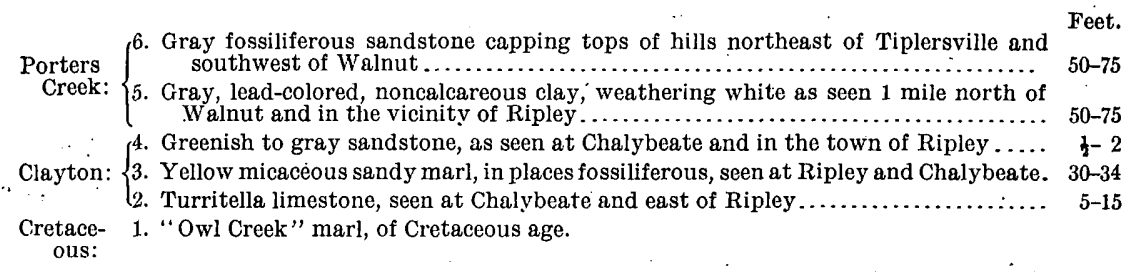

The same order of Midway strata that is found in Tippah County continues southward through Union and Pontotoc counties, but the exposures are less frequent. Three miles west of Ecru, on the farm of Clay, Lemon, is a gray sandstone similar in appearance to that in Tippah County. The hard ledge of limestone outcropping on the west bank of the branch along the Ecru and Oxford road one-half mile west of Ecru is doubtless the limestone of Clayton age, though no fossils were obtained from this locality.

One and three-fourths miles south of the town of Pontotoc, in a deep cut on the line of the new railroad, is a greenish-yellow coarse-grained sand from which a few fossils were collected 
and referred by Dr. W. H. Dall to the Midway group. Very little work has been done from Pontotoc south to Alabama. In that State the Midway is well developed and has been described in the Coastal Plain report already cited.

Detailed work in Oktibbeha County by Prof. W. N. Logan, of the Agricultural and Mechanical College of Mississippi, failed to reveal any Midway beds. In Kemper County some time was spent during the present survey along the contact between the Cretaceous and Tertiary, but the Clayton limestone, if present, does not come to the surface.

\section{WILCOX FORMATION.}

This important division of the Tertiary occupies a large area in northern and central Mississippi. It was originally named the Lignitic by Hilgard, and Doctor Safford, State geologist of Tennessee, termed it the Lagrange. A recent decision of the committee on nomenclature of the United States Geological Survey has substituted the name Wilcox, which is that of a locality in Alabama where the formation is typically exposed. . The group is made up largely of highly-stratified siliceous sands, laminated clays of various colors, interstratified in places with beds of lignite, and lignitic clays. More or less glauconite or greensand is found throughout the group, and is usually associated with beds containing marine fossils.

In Alabama, Smith has separated the old Lignitic group into six divisions. In each there are one or more marl beds, from which distinguishing fossils are obtained. He includes in the Lignitic the Sucarnochee and Naheola clays, which in Mississippi have been combined under the name Porters Creek and mapped with the Midway.

The four remaining Alabama divisions of the Wilcox can be traced by the fossiliferous marl beds for a short distance into Mississippi, but they apparently fade out, and in the northern part of the State the Wilcox is barren of fossil fauna. It might be added that the fossils mentioned by Hilgard in his Geology and Agriculture of Mississippi, page 112, were iater referred to the Middleton formation $a$ of Tennessee, or Midway of the present report. There is no single lithologic stratum in the group which can be traced throughout the State except, perhaps, the 150 or 200 feet of chocolate-colored clays immediately underlying the Tallahatta buhrstone. This bed is fairly persistent across Alabama, and occurs at various places in Mississippi. There is also a great thickness of chocolate-colored clays in the deep well at Memphis, Tenn. Certain horizons in other parts of the group are more or less persistent in some localities. Lignite beds may be used as key strata in very limited areas. The white pottery and stoneware clays are well developed in northern Mississippi and represent a fairly definite horizon for this section, but they gradually fade out in the central part of the State.

Lignite is prevalent throughout the entire group, being found in numerous places in the lower, middle, and upper Wilcox. In places it is exceedingly pure, with a black glossy color very much resembling anthracite coal. When dry it burns with a bright-red flame.

No accurate data are available for determining the thickness of the Wilcox. There are no deep wells known to have passed through it, so that the only means left for determining the thickness is by calculating the dip, principally from logs of wells which are supposed to obtain their supply of water from the same horizon in the Wilcox. Estimates of this kind have been made from the records of wells between Oxford and Batesville, between Batesville and Belen,' and between Batesville and Riverside.- The westward dip was thus found to be 16 feet between Oxford and Batesville, 17 feet between Batesville and Belen, and 18 feet between Batesville and Riverside.

The thickness, therefore, estimated from a westward dip of 17 feet per mile and a width of outcrop of 50 miles, is 850 feet. It is quite possible, however, that the dip flattens toward the west, since the arm of the Gulf at the close of Wilcox time was becoming narrower and the beds more horizontal. It is safe to assume, therefore, that 850 feet is the minimum thickness of the formation in northern Mississippi. L. C. Glenn reports that the deep well at Memphis passed through the Wilcox at a depth of 963 feet. 
The character of the Wilcox in its lower portion is well shown in the railroad cut $1 \frac{1}{2}$ miles east of Ackerman, Choctaw County. The cut is through the divide between the waters of Tombigbee and Pearl rivers, and the following section is exposed:

\section{Section of lower Wilcox formation $1 \frac{1}{2}$ miles east of Ackerman.}

Feet.

11. Lafayette sands and sandstone which has been cemented into a ferruginous mass capping top of

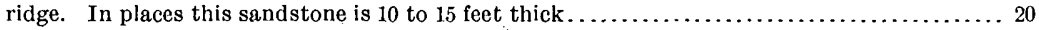

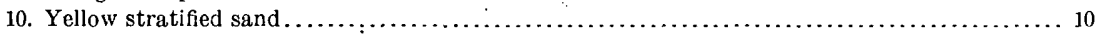

9. Bed of lignite which is not con tinuous, but changes la terally into a dark lignitic clay. When wet the whole mass has a tendency to slide down on the railroad track. Large pilings have been driven in to the earth to prevent landslides. There is more or less sand and mica throughout

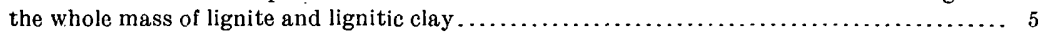

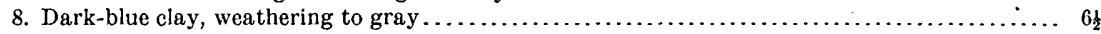

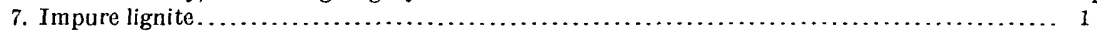

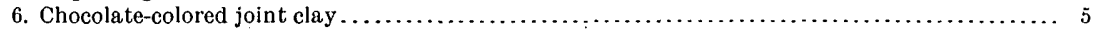

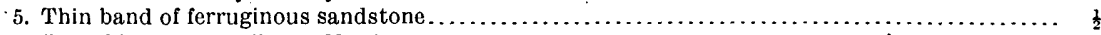

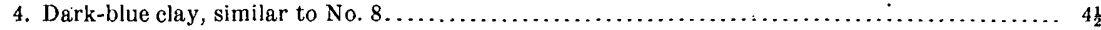

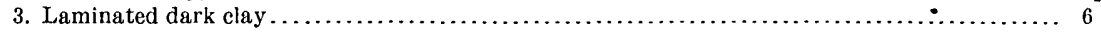

2. Laminated clay in which thin ferruginous bands alternate with bands of soft chocolate clay.... 5

1. Gray micaceous joint clay, weathering to white; bottom of cut...................... 5

The strata have a slight dip to the west. The above section shows that the prevailing material here is clay, with a slight amount of sand through the clay.

One mile north of Ackerman a section in the deep cut along the newly constructed Mobile, Jackson and Kansas City Railroad shows less clay and more sand.

$$
\text { Section of Wilcox formation } 1 \text { mile north of Ackerman. }
$$

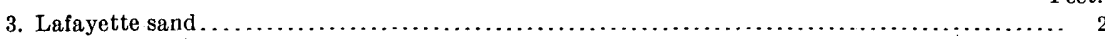

2. Cross-bedded sandy gray clays, alternating with bands of yellow clayey sand $\ldots \ldots \ldots \ldots \ldots \ldots$

1. Dark-gray sandy clays, containing fragments of leaves and lignitic material $\ldots \ldots \ldots \ldots \ldots \ldots .10$

At the north end of the cut the clayey material is replaced at the same level by a mass of coarse-grained siliceous sand of gray, yellowish, and purple colors.

Along the Mobile, Jackson and Kansas City Railroad, in the vicinity of Maben, there are numerous cuts which show a dark-blue, highly micaceous, plastic clay containing small lenses of sand. Many of the wells reach this blue clay, which produces a bad water. The clay in places is so compact that the wells do not have to be curbed. The same variation of sands and clays is found along the eastern border of the Wilcox.

Hilgard $a$ gives the following section near Hickory Flat, in sec. 33, T. 5 S., R. 1 E.:

There is a bluff about 70 feet high, which consists of alternating strata, from one-fourth inch to 2 feet in thickness, of gray and brown clay, sand, and sandy clay; the whole overlaid by a few feet of Orange sand [ Lafayette].

The following section is also taken from the same source, page 114:

Section of lignite strata, from an outcrop in T. 6 S., R. 1 E.

Feet.

3. Gray sandy clay with conchoidal cleavage, nonfossiliferous.............................. 6

2. Black laminated clay with impressions of leaves and a seam of lignite at the base ........... $1 \frac{2}{4}$

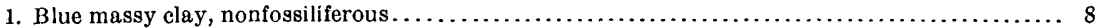

This section represents faithfully numerous outcrops in southern Lafayette and northern Calhoun counties. Some sections, however, exhibit nothing but sharp, yellow sand, with faint impressions of leaves. The region in which the above section occurs is remarkable for the number and large size of the ferruginous nodules occurring on the surface of the formation; silicified trunks, also being very common in the same position, and remarkable for the perfect preservation of their vegetable structure.

Farther west, near the center of the formation, there appears a greater amount of purer stoneware clay and less of the dark-blue lignitic clays. This is particularly true in Marshall and Lafayette counties, south of which the white stoneware clays seem to grade into the more lignitized darker clays. The same line of clays continues north from Marshall 
County into Tennessee, and their outcrop through Tennessee and Mississippi is marked by a line of stoneware and jug factories.

The purer white stoneware clays usually occur in large lenses in the coarse variegated sands below the Lafayette. In some places these lenses occur far below the Lafayette, entirely in the Wilcox sand. In others there is no Wilcox'sand above the clay, so that the Lafayette rests directly on it. For this. reason the clay was thought by $\mathrm{W} \mathrm{J} \mathrm{McGee} a$ to belong to the Lafayette formation. The clay lenses have never been found, however, entirely in the Lafayette, but they have been found many feet below the Lafayette entirely in the laminated sands of the Wilcox.

Numerous specimens of fossil leaves are found in the clays used at the potteries at Holly Springs and throughout Tennessee. Species of fossil plants collected near Somerville, - Fayette County, Tenn., by Prof. J. M. Safford, were determined by Leo Lesquereux. The age of the strata in which these fossils were found was said by Lesquereux to be lower or middle Miocene. A study of the Tertiary in central and eastern Mississippi and Alabama makes it impossible to place the Wilcox in the Miocene. It has been proved by Hilgard, . Smith, and others that the Jackson, which represents the highest division of the Eocene, is much younger than the youngest member of the Wilcox. Not only this, but there are two formations-the Tallahatta buhrstone and Lisbon beds of the Claiborne-intervening between the.upper Wilcox and lower Jackson.

At Redbanks, on the Frisco Railroad, Marshall County, is a high ridge, the waters on the north side flowing to Chewalla Creek and those on the south side to Redbank Creek. . Erosion along this ridge has been very rapid in places, removing the surficial clays and loam of the Lafayette and the yellow loam or Columbia and exposing the white stoneware clays in the stratified Wilcox sands. In places erosion has been so extensive that the lenticular character of the stoneware clays is easily determined. The material surrounding the clay lenses is a coarse, variegated sand, highly cross-bedded. Where not removed by erosion the Lafayette and Columbia overlie the Wilcox.

In sec. 25, T. 3, R. $3 \mathrm{~W}$., the following succession of strata is found, showing the relation of the sands to a more siliceous nonplastic clay, which appears in lenticular shape 100 yards long and 10 feet thick:

Section of Wilcox formation in sec. $25, T .3$ S., R. $3 \mathrm{~W}$.

Feet.

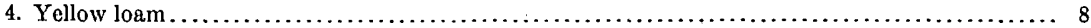

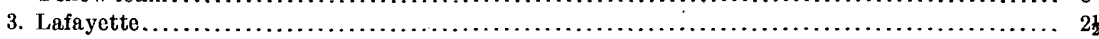

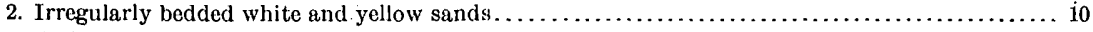

1. Red, coarse-grained sand containing layers of ferruginous sandstone; bottom of exposure. In this sand the white clay occurs.

Along the same line to the south, particularly in Lafayette County, there is a greater amount of impure, siliceous, and highly stratified clay, which from a distance often has the appearance of white chalk banks. There is likewise a less amount of clay occurring in lenticular masses. Good workable clay often occurs in horizontally bedded strata.

The following section, from a deep gully near Sid. Wyley's house, in sec. 16, T. 8 S., R. $4 \mathrm{~W}$., is typical for this locality:

Section of Wilcox formation in sec. 16, T. 8 S., R. $4 \mathrm{~W}$.

5. Yellow loam and Lafayette at surface.

Feet.

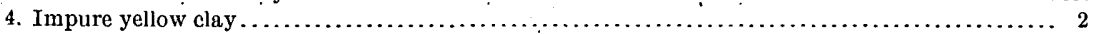

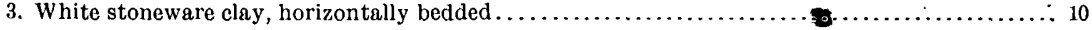

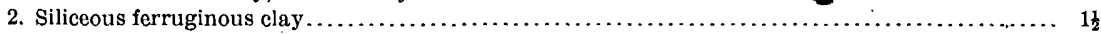

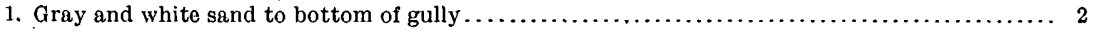

Lignite occurs to a greater or less extent throughout the entire Wilcox group, but it is more abundant and purer at certain localities than at others. It seems to be confined to local basins rather than to form continuous strata at certain horizons. It is always associated with lignitic clays bearing lignitized wood, leaves, and bark.

a The Lafayette formation: Twelfth Ann. Rept. U. S. Geol. Survey, pt. 1, 1891, p. 458. 
The lignite in a compact, pure state is impervious to water and gives rise to numerous springs where it comes to the surface. The descending waters carry more or less iron oxide in solution, and when the water is checked by the lignite bed the iron is precipitated, forming a thin roof on top of the lignite. It is often underlain and overlain by pure refractory clay, and where there is such an overlying bed the iron-charged waters are chècked before reaching the lignite.

The largest area where lignite has been found is in southeastern Lafayette and northwestern Calhoun counties. It occurs here in workable veins, reaching a maximum thickness of 6 feet.

A bed 28 inches thick occurs on A. D. Lancaster's place, in sec. 33, T. 9 S., R. 2 W. It outcrops in a deep ravine about 50 feet above Yocona Creek. Immediately above the lignite is a brown clayey micaceous sand, 10 inches thick, teeming with fossil leaves resembling oak. and a narrow lanceolate leaf or reed. A very compact black lignite, 5 feet thick, outcrops at the foot of a high hill on J. A. Hcad's land, in sec. 11, T. 11 S., R. 2 W. A second seam is reported to have been struck 15 feet below the upper layer. The lower bed is thinner than the upper and contains more iron pyrite. The upper bed marks the outcrop of numerous bold springs over a large area in this vicinity. A well at Paris, in sec. 32, T. 10 S., R. $2 \mathrm{~W}$., is reported to have passed through 18 feet of surface clay and sand, 6 feet of lignite, and 3 feet of greensand in which a stream of water was found. More or less lignite occurs along the bluff skirting the Yazoo delta in Panola and Yalobusha counties. Here it is associated with the dark-brown clays at the top of the Wilcox.

A sample of lignite was collected from a bed near De Kalb, Kemper County. Hilgard and others report lignite from near Marion, Lauderdale County, and from localities in Choctaw, Yalobusha, and Tippah counties.

In the upper portion of the Wilcox there are 200 to 250 feet of dark-brown or chocolate... colored clay. It is highly laminated and often cross-bedded. In places it contains more or less greensand and often variegated siliceous sands. The surface outcrop is most charr.a.tacteristically developed on hillsides along Yalobusha River in Grenada County, and it is 3r.: found in wells in the same area. The hills in the vicinity of Grenada expose from 100 to 150 feet of the Wilcox clays. Near the top of the hills the clay is often of a light-gray to bluish color, becoming darker near the base. More or less green, yellow, and gray sand is found alternating with the lighter colored clays. The darker clays in the river bank contain but little sand.

The following section is from the hill just west of Grenada:

\section{Section of Wilcox formation west of Grenada.}

4. Yellow loam and Lafayette capping top of hill.

Feet.

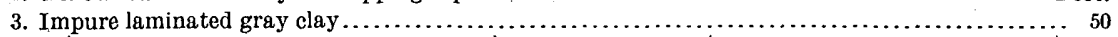

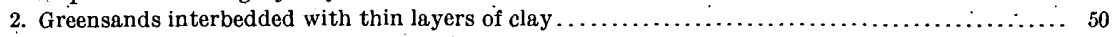

1. Darker colored laminated clays, the lower 15 feet being the dark-blue, highly cross-bedded,

shaly clay seen in the bank of the river. It is almost entirely free from sand .............. 50

Four miles west of Grenada the hard quartzite of the Tallahatta buhrstone occurs near the crest of the hills. How much, therefore, of these clays, if any, belongs to the Claiborne has not been determined.

Still farther north, along the western edge of the Wilcox hills in Panola County, the same brown clays occur associated with more or less lignite. They can be traced in the wells and outcrops along thestern edge of the Wilcox to Memphis, where 250 feet or more of dark, compact ". soapstone" or clay is reported.

\section{OLAIBORNE GROUP.}

The Claiborne is divisible on lithologic grounds into two distinct formations; the lower of these is the Tallahatta buhrstone or "siliceous Claiborne," and the upper includes the Lisbon beds or "calcareous Claiborne." 
TALLAHATTA BUHRSTONE.

The Tallahatta buhrstone, called the siliceous Claiborne by Hilgard, outcrops in a belt of territory between the Wilcox and the Lisbon beds or calcareous Claiborne. This belt varies in width from 10 miles in northeastern Clarke County to about 30 miles in Holmes, Carroll, and Montgomery counties.

In lithologic character the Tallahatta buhrstone stands out in sharp contrast to the soft, unconsolidated sands, clays, and lignites of the Wilcox, and likęwise to the more marine deposits of calcareous clays and fossiliferous marls which were laid down immediately. after the deposition of the buhrstone. The principal rocks of this formation consist of the following:

1. Aluminous sandstone of a prevailing gray to white color and often containing a large amount of oxide of iron. More or less fossils, principally casts, have been found in this rock in both Mississippi and Alabama.

2. Next in order of abundance is the siliceous and aluminous clay stone. This rock is found in numerous places near the Alabama border in Clarke and Lauderdale counties, but north of this the harder sandstones are the prevailing materials.

3. Quartzitic sandstone or "Feldsen mur." This is the rock which has given the name to the whole series. 'It is an exceedingly hard sandstone which, by metamorphism, has lost much of its original sandy character. Some of the specimens collected show the sandstone in the process of change from the coarse-grained sand to the hard quartzite. The quartzite is usually found in layers ranging from 2 to 3 feet thick. When long exposed to eroding agents it is found strewn along the hillsides in large, flat bowlders. Smith $a$ considers the quartzite to b'e the basal member of the Tallahatta buhrstone formation. This is overlain by aluminous clay stone which is flecked with small fragments of clay or "gallstones." This clay rock is very light gray to white in color, containing two sets of joints approximately at right angles to each other. In places, as at Basic, in northern Clarke County, these joints have been filled with sand and other materials forming small dikes, and the whole cemented together with iron oxide. The intruded material is more resistant than the indurated clay stone and gives rise to unequal weathering.

4. Greensand and marls. These are found in less abundance than any of the other materials. However, more or less greensand grains occur throughout the siliceous sandstone of the formation.

An interesting section at Vaiden is given by Hilgard: $b$.

In the middle of the cut the coarse, glauconitic, dark orange-colored, ferruginous sandstone forms a pretty uniform stratum about 3 feet thick; it is in this that the fossils are most abundant. These aro preserved as.impressions and nuclei only. Underlying this rock and in the cut adjoining northward alternating with it there occurs a stiff amorphous clay with sharp sand and some greensand grains, also of deep orange tint and exhibiting traces of fossils.

On the south side of Kirkwood Ferry, about sec. 11, T. 16 N., R. 5 E., is a bluff about 70 feet high showing the Tallahatta buhrstone, of which Hilgard $c$ gives the following section:

Section of Tertiary strata at Kirkwood Ferry.

6. White siliceous sandstone; nonfossiliferous . Feet.

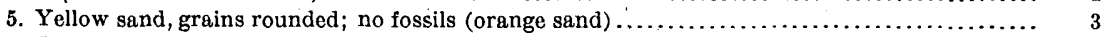

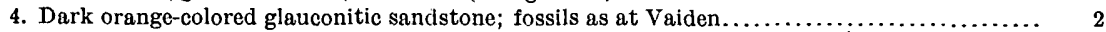

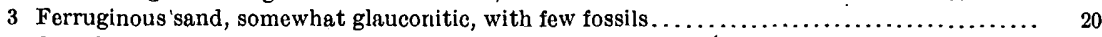

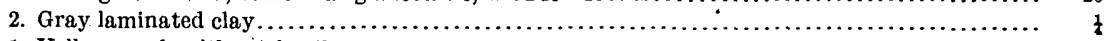

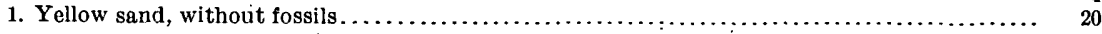

No accurate measurement of the thickness of the Tallahatta buhrstone has been made in Mississippi. The city waterworks at Kosciusko struck a bed of fossiliferous marl at a depth of 65 feet. This marl bed is immediately overlain by a stratum of hard "flint rock" 34 inches thick, and is underlain by a stratum of softer rock. 
At a depth of 150 feet a second bed of fossiliferous marl was found which contained fewer fossils and more greensand than the upper bed. A sufficient number of fossils were not kept from this well to determine the exact horizon of the two beds. On Yokahockany River just south of Kosciusko the quartzitic sandstone outcrops along the road near the bridge. This is doubtless the same horizon as the "flint rock" 65 feet below the surface in the Kosciusko well. Considering the "flint rock" as the base of the Claiborne and the upper marl bed as the uppermost fossiliferous bed of the Wilcox, we then have 65 feet of Tallahatta buhrstone in the well. The elevation of the top of the well is about 15 feet above the railroad track at Kosciusko, or 437 feet above sea level. The hills, which are capped by the Tallahatta buhrstone 5 miles north of Kosciusko, rise to an elevation of about 600 feet, barometric reading. Considering the rocks horizontal, we have a thickness of 220 feet for the entire formation.

Smith has estimated the thickness of the Tallahatta buhrstone in "llabama to be at least 300 feet. A less thickness should be expected in central Mississippi than in Alabama, since the width of the outcrop becomes less to the north and the formation has not been found to cap even the highest hills north of Yalobusha River in Grenada County.

This formation oflers a strong contrast, in both topography and character of materials, to the adjacent older and younger formations. The hills of the Tallahatta buhrstone are high and, where capped by the harder portions of the sandstone und quartzite, are very precipitous and rugged. In northwestern Neshoba and northeastern Leake counties Pearl River and some of its tributaries have cut out deep ravines in the sandstone, giving rise to wild and picturesque scenery. Short-leaf pine is the principal timber on the hills, with oak, hackberry, gum, and hickory along the creek bottoms. The soil is thin and has a deep, Indian-red and often blood-red color. The decomposition of the sandstone, which contains: a large amount of iron oxide, gives the striking red color to the soil. It is easily distin-' guished from the orange-colored soil of the Lafayette and from the chocolate and gray soils of the Wilcox and Lisbon formations. The region is very sparsely populated and undeveloped, owing to the poor quality of soil and the readiness with which it "wears out" and' washes away.

The old shore line at the beginning of the deposition of the Tallahatta buhrstone is traceable from the Alabama line, 4 miles south of Hurricane Creek post-office, in a general northwest direction past Eastville to a short distance southwest of Philadelphia, then bearing a little more to the north through Plattsburg and Hinge, 4 miles west of McCool, through French Camp and Minerva to a point 4 miles west of Grenada, where the formation dies out.

The principal variation from a direct line of outcrop extending from the Alabama border to the locality 4 miles west of.Grenada is due to the irregularity of the surface configuration.

The geologic map of the State (PI. I) shows that the formations older than the Tallahatta buhrstone, after swinging into Mississippi from Alabama, begin to assume a nore nearly north-south direction. The huhrstone trends from northwest to southenst, while the younger Lisbon, Jackson, and Vicksburg gradually take an east-west direction!. This is due to a more rapid filling in the northern part of the embayment about the close of the IVilcox period. The broad embayment which at first extended from northern Alabama across the present State of Mississippi and eastern Arkansas had, at the beginning of Claiborne tiue, become reduced to a comparatively narrow arliı of the sea, which still extended north as far as southern Illinois. The great amount of sediment which was being carried into. the embayment from the east, north, and west gradually filled in and finally closed the narrow inlet. Before it was entirely closed there was a gradual lessening of the dip of the sea floor on which the material was being deposited. The last formation to be deposited was, therefore, almost horizontal, with a slight dip to the deeper sea. In recent investigations along Crowley Ridge, in northeastern Arkansis, the formations were found to have a very slight dip to the south.

A good opportunity for investigating the upper division of the Tallahatta buhrstone is given along Okatibee Creek between Basic and Enterprise. About 2 miles southwest of Basic and 2 miles northeast of Enterprise, where the New Orleans and Northeastern Rail- 
road conies nearest to Okatibee Creck, the aluminous clay stone of the upper part of the buhrstone disappears beneath the fossiliferous beds of the overlying Lisbon beds.

At Basic station the principal part of the deep railroad cut is in the aluminous clay stone, which occurs in solid ledges 2 to 6 feet thick. When dry it is very light, and from a distance may be taken for white chalk The top of the hill, above the cut, is covered with large bowlders of hard, yellow sandstone with flint-like nodules through it.

Doctor Hilgard mentions the presence of a yellow aluminous sandstone in southern Neshoba County. The rock, he says, "is very poor in fossils at its northern edge, but becomes richer as we advance southward."

In the bed of Chunkey Creek, near Chunkey station, the aluminous clay stone forms high, perpendicular walls. Here, as at Basic, joints through the rock are well developed.

On Thomas Tillman's land, in sec. 9, T. 7 N., K. 11 E., the more siliceous sandstone of the Tallahatta buhrstone comes to the surface. It is highly colored with rusty and pink streaks of iron oxide. After long exposure it becomes soft.and easily broken. It occurs in thin layers, 3 to 8 inches thick, interbedded with an indurated clay. The stone here is quarried and used locally for foundation pillurs, chimneys, and hearthstoues. It withstands a large amount of heat without cracking and is therefore known as the "fire rock."

Still farther north, between Philadelphia and Edinburg, are numerous outerops of the soft iron-stained sandstone. A hill on the south side of the road one-half mile west of Worth post-office, in sec. 25 , T. 11 N., R. 10 E., Neshoba County, rises about 75 feet above the bed of the creek. Near its crest is a ledge of sandstone from which large bowlders have broken loose and rolled down the hillside, almost completely covering it.

In western Neshoba and eastern Leake counties the typical "red lands". of the Tallahatta buhrstone are well developed. The decomposition of the sandstone rock forms a deep-red clay loam. It was at first confused with the Lafayette, but the red clay loam is always free. from pebbles and ferruginous conglomerate.

In the bed of Pearl River at Edinburg there is a soft aluminous micaceous sandstone con-. taining small angular fragments of flint or chert. The presence of iron oxide in the rock gives it a highly mottled appearance. The rock occurs in thin layers 8 to 10 inches thick interbedded with micaceous, indurated siliceous clay. The pillars for the bridge across Pearl River are said to have come from the bank of the river just below the bridge.

Two and one-half miles northeast of Edinburg, on Mr. Unsel's land, a very hard quartzose sandstone, much harder than any found farther south, occurs on the crests and sides of the hilis and is used locally for building stone. The fine pillars under many of the buildings in Edinburg are said to have come from the Unsel place.

The hills in northwestern Neshoba, northeastern Leake, and southeastern Attala counties; where not covered with Lafayette and detritus, show the presence of the Tallahatta buhrstone. In some places it is very soft and white; in others it, is more flint-like and often contains casts of fossils.

Along the eastern edge of the buhrstone area in the vicinity of Alice there is apparently more greensand near the base of the formation than higher up. The greensand is mixed. with yellow clays, and below it is a grayish to dark-brown clay containing free sand.

Along the road between Kosciusko and Edinburg, in sec. 15 (?), T. 13 N., R. 8 W., is a bed of marl mixed with greensand underlying a thin stratum of ferruginous sandstone. The marl bed teems with fossils, but unfortunately the species collected from this place were not sufficient to determine whether it is Claiborne or upper Wilcox.

Five miles north of Kosciusko the main body of the quartzitic sandstone occurs. On J. C. Bell's land there are two sandstone ledges separated by 20 to 25 feet of clayey sand. The upper ledge is 10 to 12 feet thick; the lower one is partly covered by detritus, but is perhaps 15 feet thick. When freshly dug from the hillside the sandstone is white, fine grained, and highly siliceous, with pink streaks through it. Some of the ledges farther down the slope have lost their original sandy character and are now almost a pure quartzite. The bust steel hammer is easily battered by striking it against this rock. 
In the railroad cut at Hoffman, Holmes County (PI. IV, $B$ ), the following section of the Tallahatta buhrstone was obtained:

\section{Section of Tallahatta buhrstone at Hoffman.}

Ft. In.

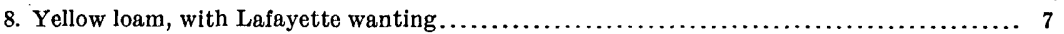

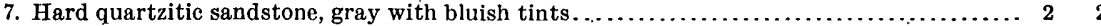

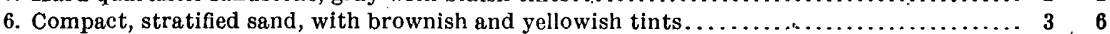

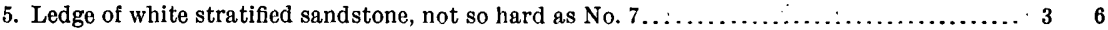

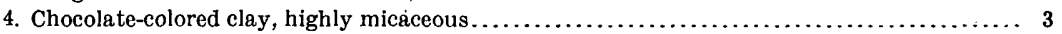

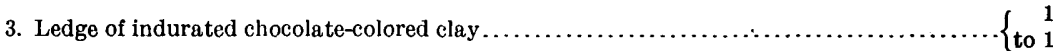

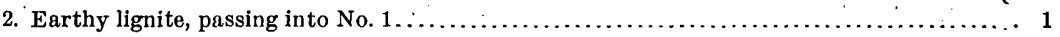

1. Chocolate-colored clayey sand, highly micaceous, containing small iron concretions; bottom

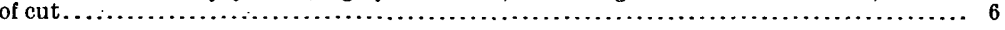

The Tallahatta buhrstone comes to the surface in the hills on the west side of the creek which empties into Yokahockany River at Ethel, in eastern Attala County. The principal outcrops occur in secs. $33,30,29,28$, and $21, T$. 15 N., R. 8 E. In each of these places the rock is a gray, soft, micaceous sandstone, containing more or less iron oxide. It is found well up on the hillsides 30 to 40 feet above the stream. Its relation to the underlying and overlying strata is not known, owing to the large amount of detritus on the hillsides. However; as this is the easternmost outcrop known in this latitude, the sandstone must represent something like the base of the formation. The elevation of Ethel is 435 feet above sea level.

The Ethel and Kosciusko sections offer an opportunity for determining the dip of the formation. The hard quartzitic layer just above the fossiliferous marl bed in the well at Kosciusko has been considered above (p. 29) to be the base of the Tallahatta buhrstone. The altitude of this quartzitic horizon is 380 feet above tide. Considering the base of the formation to come to the surface near Ethel at an altitude of 475 feet, and the distance between Ethel and Kosciusko to be 9 miles, we thus get a southwesterly dip of $10_{5}^{5}$ feet to the mile.

A comparison based on railroad elevations of the Hoffman and Kosciusko sections leads inevitably to one of two conclusions-(1) that the fossiliferous marl bed 65 feet beneath the surface in the Kosciusko well is not Wilcox, but a part of the Tallahatta buhrstone, or (2) that there is considerable warping of the strata which has never been taken into consideraation.

The elevation of the marl bed in the Kosciusko well is approximately 380 feet above tide. At Hoffman, 12 miles west of Kosciusko, what has been considered the base of the formation outcrops in the railroad cut at an elevation of 293 feet above tide, or 87 feet lower than the buhrstone bed at Kosciusko. If the quartzite at Hoffman were at the base of the Tallahatta buhrstone, there would be a strong dip of $7 \frac{1}{4}$ feet per mile to the west. But the buhrstone outcrops at Ethel, 9 miles east-northeast of Kosciusko, and again 6 miles east of Winona. It is therefore impossible to get the base of the formation at Hoffman unless there is a strong folding of the strata in this region. Such folding has never been detected by anyone, and we are thus forced to the conclusion that the fossiliferous marl bed in the Kosciusko well is in the Tallahatta buhrstone and that the formation is much thicker than estimated above (p. 30 ), or else the quartzitic ledge is not the base of the formation.

In the hills 6 miles east of Winona a gray sandstone occurs having the same character as that found near Kosciusko, Hoffman, and other places farther south, showing both the hard quartzitic layer and the softer aluminous sandstone containing mica and highly colored with. iron oxides.

The northernmost place in Mississippi where the Tallahatta buhrstone has been found is on the poorhouse farm 4 miles west of Grenada, Grenada County. Here the blue to pink-tinted quartzite occurs in large, rough bowlders on the highest hills. If the old shore line representing the eastern edge of the Tallahatta buhrstone continued its northwest course north of Yalobusha River, as it does from the Alabama line to Grenada, the Claiborne north of this point has been removed by the same agency which carved out the Yazoo bottom. 


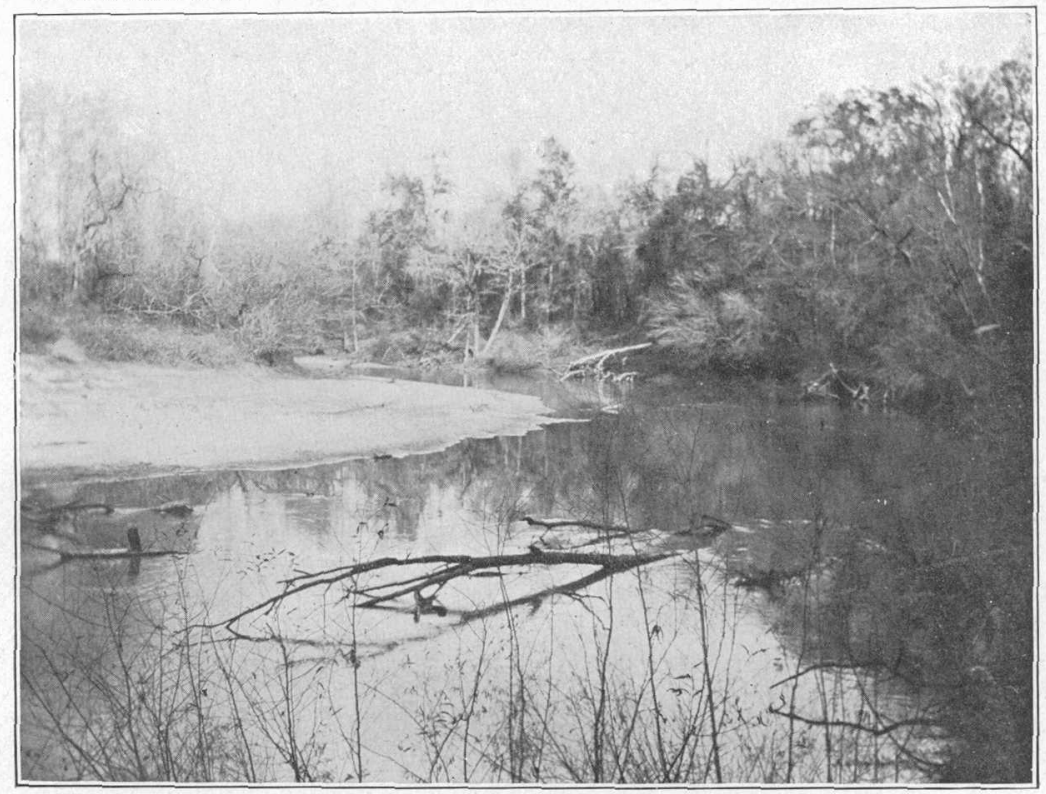

A. BED OF GLASS SAND ON PEARL RIVER NEAR BYRAM.

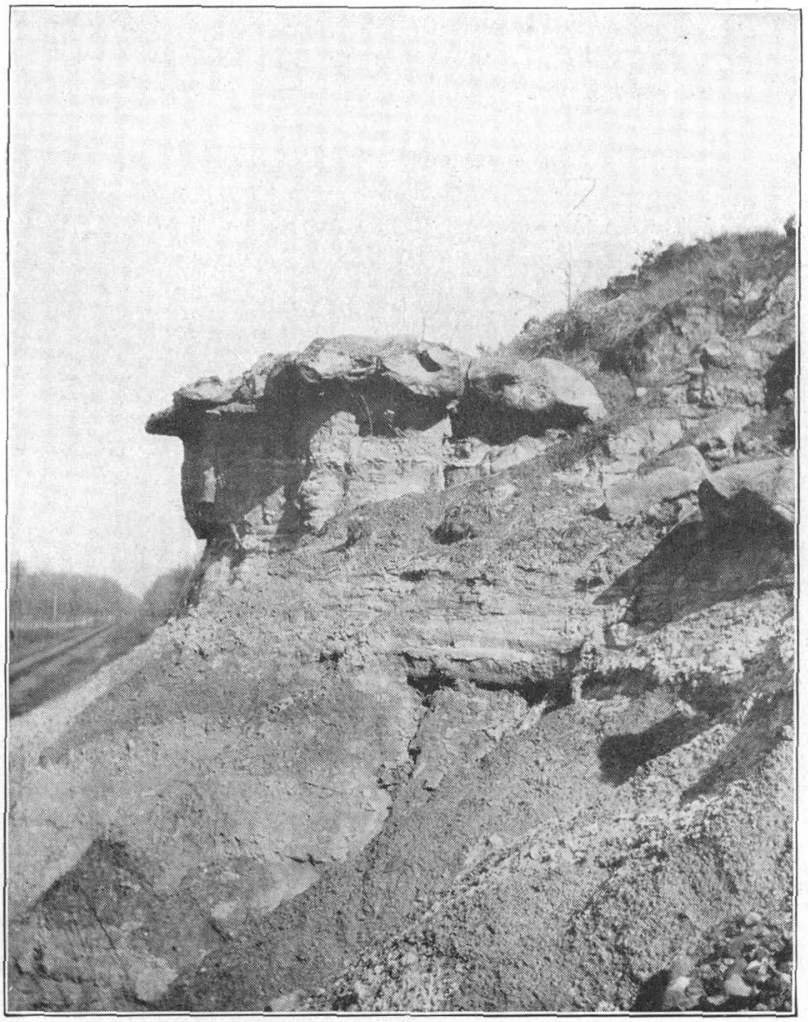

B. LEDGE of tallahatTa QUARTZITE, hofFiman. 
LISBON BEDS.

The uppermost division of the Claiborne is a series of clays and sands, which Hilgard called "calcaieous Claiborne." The formation is estimated to be 150 feet thick in Alabama, where it is composed of calcareous sands and laminated and lignitic clays. There is one horizon in Alabama in which a distinguishing fauna occurs. This is a bed of yellowish ferruginous sand 15 to 17 feet thick, containing numerous species of beautifully preserved Claiborne fossils. A large number of the fossils in the Lisbon beds range through the overlying Jackson and Vicksburg formations.

The fossiliferous horizon above mentioned has been described by Hilgard as occurring on Falling Creek, near Quitman, Clarke County, Miss., and on Suanlovey Creek, west of Enterprise. L. C. Johnson has also collected fossils from the same bed at the Wautubbee cut, southwest of Enterprise. Here it is $\mathbf{1 7}$ feet thick and is the best collecting bed of the Claiborne so far found in Mississippi.

The same bed outcrops again 4 miles northiwest of Newton, in Newton County. The material in which the fossils occur is a blue calcareous sandy marl. The bed here is much thinner than at Wautubbee. Frank Burns, of the Smithsonian Institution, has made a large collection of fossils from this place, as well as from numerous other places west of Hickory and along the road between Hickory and Quitman. The fossils have all been examined by Dr. W. H. Dall and referred by him to the Lisbon beds of the Claiborne. Near Hickory and southward to Quitman most of the fossils occur in a sandy "soapstone" or clay.

One mile south of Enterprise, on Chickasawhay River, is a bed of Scutella lyelli, which has become cemented into a hard rock, as reported by Mr. Burns. The Scutella bed overlies a bed of fine ash-colored marl, which contains a large amount of greensand, but is devoid of fossils at this place.

In the railroad cut $1 \frac{1}{2}$ miles west of Decatur Claiborne fossils occur in a bed of dark-blue glauconitic clay marl. 'This is doubtless near the base of the formation, as the buhrstone outcrops about 4 miles northwest of Decatur.

JACKSON FORMATION.

In Alabama the Jackson and the succeeding formation, the Vicksburg, have been classed together under the name of St. Stephens. In Mississippi, however, the two formations can usually be separated quite readily and will be treated as two distinct formations.

The essential materials of the Jackson group are gray calcareous clay marls and bluish lignitic clays, with greensand and gray siliceous sands. From a lithologic standpoint there is very little difference between the calcarecous clays and marls of the upper Claiborne and those of the lower Jackson. In general the color of the clays becomes lighter in the Jackson, with possibly a less amount of lignitic material. So far, however, the principal reason for keeping the two formations separate is based on paleontologic evidence. In some localities where fossils have been collected, the so-called Claiborne fossils were so evenly distributed with those of Jackson age that it has been difficult to say in which formation the beds belong. There is need of a more comprehensive study of the stratigraphy in connection with the fossils in order to draw the line between the two formations correctly. This line as mapped in Mississippi is, therefore, only approximately correct. The upper ferruginous sandy marl containing Claiborne fossils has been seen in but few places in the State. Smith, $a$ in speaking of the distinction of Claiborne and Jackson rocks, says:

The rocks of the Claiborne group are distinguished from those of the white limestone (Jackson and Vicksburg of Mississippi) by the presence of glauconite in large proportion, and this Scutella bed is the flrst of the ferruginous beds of the Tertiary. We are undecided whether this Scutella bed should go with the white limestone or with the Claiborne, since the fossil is found in both formations.

Only a few feet below this Scutella bed are the Claiborne fossiliferous sands, so that even where the formations have been best studied there seems to be a gradation in both the

Bull. 283-06-3

$a$ Coastal Plain of Alabama, p. 111. 
fossils and stratigraphy from the upper Claiborne to the lower Jackson. Many of the forns found in the Claiborne are found throughout the Jackson and the succeeding formation, the Vicksburg.

Conrad $a$ described a large number of fossils from the vicinity of Jackson, and was the first one to give that name to the formation.

He assigned [says Dall $b$ ] to the strata their proper stratigraphical position above the Claiborne and below the Vicksburg, although from the nature of the material he had for examination he failed to recognize the true faunal relationship of the several horizons. His investigations led him to the conclusion that there.were no forms in common with the Vicksburg series, and but four or five with the Claiborne. Subsequent observations, however, have shown in Mississippi, as well as in Alabama, that there are many forms common to the three horizons. Such common species as Cardita planicosta and Cardita rotunda of the Claiborne, with many less usual types, are found, while the list of species reported as likewise occurring in the Vicksburg is very large.

There is one distinguishing fossil, the Basilosaumus (Zeuglodon), which has been found only in the Jackson marls. ' It is usually found on the prairies where the streams have removed the surface soils. These bold prairies, somewhat similar to those found in northeastern Mississippi, are of common occurrence over the Jackson area and serve to distinguish the Jackson from the Claiborne.

Hilgard, $c$ in his study of the formation around Jackson, observed what he considered a northern dip of the Jackson beds. He says:

According to the levelings of the N. O., J. and G. N. R. R., the city of Jackson is situated 45 feet higher than Canton, Madison County, $d$ which is distant 25 miles due north from the former place. . . . At Canton we find the highest strata, apparently, of the Jackson group-the gray calcareous clay matrix of the $Z$ euglodon-occupying the surface, though at a moderate depth (20 to 30 feet) the lignito-gypseous material is struck, yielding undrinkable water. The same strata are seen all the way between Canton and Jackson, and crop out very characteristically half a mile north of the statehouse. Yet we find lignitic strata cropping out on Moodys Branch, a mile northeast of the statehouse, and that at a hypsometrical level obviously higher than that at which, a mile below, we find the beds of blue fossiliferous sand cropping out on Pearl River and in the bed of Dry Creek. Making due allowance for the undulations of the surface at both stations (Canton and Jackson), the surface of the lignitic strata, so far from exhibiting a southward dip, is still slightly higher at Jackson than at Canton. It seems difficult to account for this condition of things unless by supposing a local upheaval of the underlying formation to have taken place before the deposition of the lowest of the Jackson stage.

Doctor Hilgard's theory of a northern dip of the strata in the vicinity of Jackson is further substantiated by the occurrence of outliers of the Vicksburg limestone west of Madison. These outliers occur on the hills along the watersheds of Pearl and Big. Black rivers, but if the southern dip of the Vicksburg, as observed along Pearl River at Byram, continued northward the Vicksburg would not touch the tops of even the highest hills, as the following elevations will show. The elevation of the lowest member of the Vicksburg limestone on Pearl River, 3 miles above Byram, is about 255 feet above tide. Byram, on the bank of Pearl River, is 264 feet above tide. The United States Geological Survey bench mark in sec. 3, T. 7 N., R. 1 E., is 415 feet above tide. This is 1 mile from the northernmost outcrop of the Vicksburg outlier in sec. 10, T. 7 N., R. 1 E., west of Madison, where the elevation of the lowest member is 400 feet above tide, barometric reading. The distance between the northernmost outlier and the outcrop on Pearl River above Byram is 20 miles and the difference in elevation is 145 feet. The southward dip would, therefore, be $7 \frac{1}{4}$ feet to the mile.

The dip thus obtained is much smaller than that noticed along Pearl River between Jackson and Byram. D. W. Langdon, $e$ who studied the strata along this part of the river, says:

Six miles above Byram the strata show a dip of about 20 feet in a hundred toward the south. . . . Still farther south the strata dip southward very rapidly, as much as 5 feet in a hundred.

a Proc. Philadelphia Acad. Nat. Sci., vol. 7, 1855, pp. 257-263.

$b$ Correlation papers-Eocene: Bull. U. S. Geol. Survey No. 83, 1891, p. 68.

c Geology and Agriculture of Mississippi, 1860, p. 128.

$d$ According to Gannett, Jackson is 67 feet higher than Canton.

e Am. Jour. Sci., 3d ser., vol. 31, pp. 202-209. 
The dip to the west was estimated by Mr. Langdon to be 6 to 7 feet per mile.

From the above it seems that there is a great irregularity in the dip of the Jackson formation. From Jackson southward the dip to the south is very great, but farther north it gradually flattens, and probably becomes a slight dip to the north. The irregularities in the dip of the strata in Mississippi may be due to the same cause as that which in Alabama produced the lower Peach Tree anticline, Hatchetigbee anticline, and Bethel fault. $a$

The stratigraphic position of the Jackson is between the Claiborne and Vicksburg, as pointed out by Conrad, Hilgard, Smith, and others. Its area is more extensive than that of either the Claiborne or Vicksburg, occupying a stretch of country which is narrowest in the east and gradually widens to the west. The increasing width to the west is explained by the fact that in the east the dip to the south is much greater than in the west, where the country becomes more level and the dip in some places almost horizontal.

The Jackson area can usually be traced across the country by the rich calcareous prairie soils. Owing to the absence of deep-well records over the area, it has been impossible to determine the thickness of the formation. Estimates have been made from the width of the outcrop, but the irregularities in the dip of the strata in the vicinity of Jackson have rendered the results unreliable.

In Alabama the thickness of the St. Stephen, which includes the Vicksburg and Jackson, is estimated at 350 feet. The Vicksburg in Mississippi is less than 110 feet thick, so that if the combined thicknesses in Mississippi are the same as in Alabama we have 240 feet for the Jackson. It is doubtless much thicker, however. The bluff at Yazoo City shows 180 feet of Jackson clays in one continuous section, and the formation outcrops along the bluff for 12 miles to the north and about 30 miles to the south. With a thickness of 180 feet at Yazoo City, near the northern limit of the area, and with a very slight southward dip, it is more than probable that the entire thickness is at least 350 or 450 feet.

The type locality of this formation, as above mentioned, is at the city of Jackson. This has been the classic collecting ground for the paleontologist, and hundreds of specimens have been found here. The beds in which the well-preserved fossils occur are found at the wagon bridge across Pearl River, on Town Creek, near its mouth, and along a deep ravine about 1 mile north of the old capitol. At none of these localities are the strata horizontally bedded, nor do they preserve their lithologic unity so that any one bed can be traced for any great distance. The gray or greenish marl, replete with fossils, may in 100 feet change to a black lignitiferous clay. Jackson fossils have also been collected at Moodys Branch and McNutt Hill.

The high bluff skirting the east rim of the Yazoo bottom is in most places very steep. The top of the bluff is covered with a much younger formation, the loess, which will be described later (see pp. 48-49). Underneath this loess capping the Jackson may be seen for a distance of about 35 to 40 miles south of Free Run, in northern Yazoo County. Many of the streams have cut through the loess and have exposed the Jackson for some distance back from the western edge of the bluff. At Yazoo City and for several miles north and south this bluft affords excellent sections of a gray to bluish clay marl bearing a typical Jackson fauna. The height of the bluff above the river is 280 feet. The lower 180 feet are composed of gray calcareous clay containing crystals of gypsum, Zeuglodon bones, and other Jackson fauna. Above this are 10 to 12 feet of Lafayette sands and gravel, and this in turn is overlain by about 100 feet of loess.

The "bald prairies," underlain by the gray calcareous clays bearing the bones of Zeuglodon, can be traced across the counties of Madison, Scott, northern Smith, Jasper, southern Clarke, and northern Wayne, into Alabama.

The country along Chickasawhay River and some of its tributaries affords better opportunity for collecting Jackson fossils than the central part of the area. Along the Chickasawhay, in sec. 21, T. 1 N., R. 16 E., Clarke County, is a bluff 30 feet high of calcareous clays, from which Hilgard $b$ collected many Jackson fossils. He mentions, among other localities 
from which he collected Jackson fossils in Clarke and Wayne counties, Trotter's. plantation, in sec. 3 , T. 10 N., R. 7 W.

The Jackson has usually been described as being entirely made up of marls and clays, but recent investigations along the line of contact between the Jackson and Vicksburg have shown that there are from 50 to 75 feet of yellow, gray, or white siliceous unconsolidated sand at the top of the Jackson. Whether from a paleontologic standpoint this should be considered Jackson or Vicksburg is doubtful, since no fossils have been found in these sands. They are regularly stratified, showing that they were deposited very near the old shore, in more or less current. In places near the surface the sands are often cemented with iron oxide, causing some strata to resist erosion more than others. Thin bands of clay stone are also frequently found throughout the sands. They outcrop in various places in southern Madison County, where the Vicksburg limestone forms outliers on the upper Jackson. The exact stratigraphic position of the sands was first discovered in this vicinity. The following sections were obtained in Hinds and Madison counties, near the contact between the Jackson and overlying Vicksburg.

Just west of the house of Handy Washington (colored), in sec. 9, T. 7 N., R. 1 E., the Vicksburg, which overlies the upper Jackson, caps the top of the hill. At the base of the limestone are 2 feet of dark nonfossiliferous clay. Below this are 8 to 10 feet of fine, sharpgrained, white siliceous sand, with irregular horizontal bands of iron-stained sand containing small particles of mica and grains of glauconite. In appearance this is similar to some of the sand in the Grand Gulf, but in two different places the stratified sand lies unmistakably underneath the Vicksburg limestone. Below the sand and extending to the bottom of the hill is a bed of stratified clay of a general gray color, with a large number of iron-colored clayey bands and occasional layers of dark-blue clay: The whole is quite siliceous and contains much mica.

A good section of the upper Jackson is obtained along the road on the steep hill on the south side of a branch in sec. 16, T. 7 N., R. 1 E.

Section of upper Jackson formation in sec. 16,T. 7 N., R. $1 \mathrm{E}$.

6. Columbia and Lafayette at top of hill.

Feet.

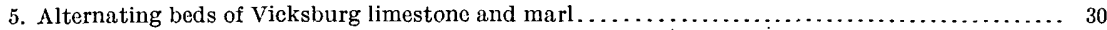

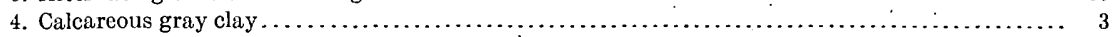

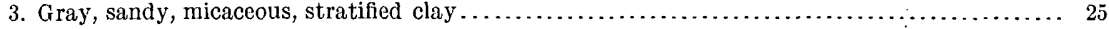

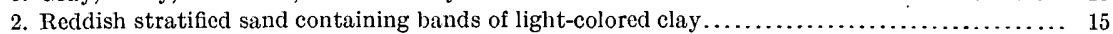

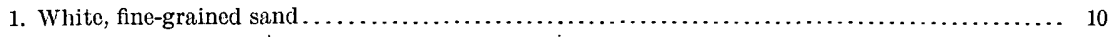

Still farther north the white stratified sand often occurs in large deposits sufficiently pure for commercial purposes.

In a deep gully on the east-west road in the NW. $\frac{1}{4}$ sec. 2 , T. 7 N., R. 1 E., the following section of the Jackson sands occurs:

Section of Jackson sands in sec- 2; T. 7 N., R. 1 E.

Feet.

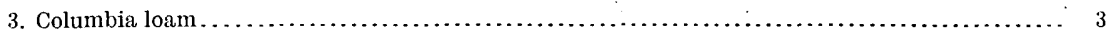

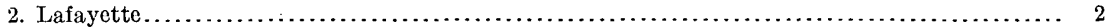

1. Very fine-grained stratified sands containing mica, but no fossils or lime. The sand varies from cream white to pink in color and weathers into fantastic shapes.......................... 10

Along Pearl River, between Jackson and Byram, the material at the top of the Jackson is decidedly sandy.

In a deep branch flowing westward in the southern part of sec. 15, T. 4 N., R. 1 E., the following relation exists between the Jackson and overlying Vicksburg limestone:

Section of Jackson and Vicksburg formations in sec. 15, T. 4 N., R. 1 E.

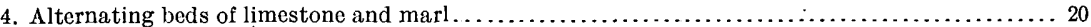

3. Chocolate-colored fossiliferous clay, containing crystallized gypsum and alum $\ldots \ldots \ldots \ldots \ldots \ldots$

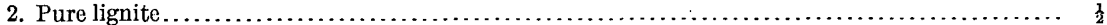

1. Green and chocolate-colored sands, cross-bedded, with occasional bands of clay, nonfossiliferous. 20 
The stratigraphic break between the Vicksburg and Jackson here seems to be the band of pure lignite which comes between the fossiliferous clay and the nonfossiliferous sand. Still farther down the river the sand at the base of the limestone shows at the water's edge, with a strong southward dip.

This sandy nature of the upper Jackson may be traced throughout the length of the Jackson-Vicksburg contact. The most complete section showing the contact between the two formations was obtained on the enst side of the ridge on the Siwel and Bradie road, in the NE. $\frac{1}{4}$ sec. 22 , T. 5 N., R. 1 W. The base of Vicksburg limestone here is 400 feet above tide.

Section of Jackson and Vicksburg formations in sec: 2Q, T. 5 N., R. $1 \mathrm{~W}$.

5. Thin strata of white and yellow sand.

Feet.

4. Yellow sand with thin bands of iron sandstone, onc-eighth inch in maximum thickness. The

whole is interbedded with white, chocolate, and purple clays, the latter $1 \frac{1}{2}$ inches thick.......... 5

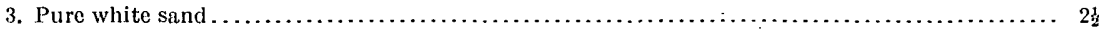

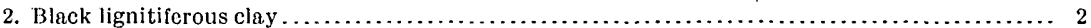

1. Pure white siliceous sand containing mica......................................... 5

The remainder of the hill below is mostly covered with the wash from above, but where the strata are exposed they are highly stratified layers of sand gradually becoming more clayey near the base of the hill; and finally passing into a clay marl of the Jackson prairies at 350 feet above tide. Whether this sand is the same as the Red Bluff horizon, mentioned by Hilgard, $a$ or not, it is impossible to say. Its stratigraphic position is the same, but no fossils have yet been found in the sandy strata.

\section{VICKSBURG FORMATION}

The Vicksburg formation, first studied by Conrad, occupies an area lying just south of the Jackson formation and of much smaller extent. It consists of a semicrystalline limestone in beds varying from 1 foot to 3 feet in thickness, alternating with beds of sandy fossiliferous marl of about the same thickness. The beautiful, well-preserved fossils of the Vicksburg are mostly found in these beds of marl. This highly interesting formation marks the end of the marine conditions of the Tertiary in western Mississippi. Its outcrop occupies a narrow band just south of the Jackson area and extends across the State from the typical outcrop at Vicksburg through Warren, Hinds, Rankin, Smith, Jasper, and Wayne counties into Alabama, where the Vicksburg and Jackson are inseparable on stratigraphic and paleontologic evidence, and are taken together and called the St. Stephens or White limestone. The Vicksburg outcrop is in most cases very narrow. Often the entire thickness is represented in one hillside. Where the country is more level the width of outcrop becomes greater, in places reaching 3 to 5 miles.

There is a marked difference in the character of the various beds of limestone. Usually those near the surface are more or less affected by weathering, and have therefore become soft and often yellow. Below the zone of weathering the rock is often hard blue limestone suitable for a building stone. In some places the hard blue limestone occurs near the surface and forms small bluffs along the streams.

There is no hard limestone of any consequence in the underlying Jackson and none in the overlying Grand Gulf, so that there is little possibility for mistaking the Vicksburg limestone. It is therefore $\Omega$ horizon ensily recognizable in determining the dip of the Tertiary rocks.

The thickness of the Vicksburg is usually overestimated. There are 65 to 75 feet of the alternating limestone and mirl beds represented in the bluff at Vicksburg. At no other place is there found as great a thickness in one continuous section. Below thelimestone are 25 to 30 feet of lignitic clays and lignite. The full thickness of the formation is doubtless represented in the Vicksburg bluff. 
An interesting feature of the formation is the fact that outliers, several miles removed from the main hody of the formation, have been recently discovered. They occupy some of the highest land along the divide between Big Black and Pearl rivers, in the southern portion of Madison County. There are also two outliers at but a short distance from the main body of Vicksburg, one near Tinnin and the other near Brownsville. The details of the formation have been more thoroughly studied between Pearl and Big Black rivers than at any other locality. A careful study of the formation across the State would doubtless reveal a large number of outliers.

The localities of the Vicksburg outcrop across the State are numerous. There are in this formation a few hard strata of blue limestone, which resist the weathering agents, and where the country is somewhat hilly this hard limestone is almost always found at or near the surface (Pl. II, $A$, p. 12).

The most complete section of the formation at any one place is in the bluff at Vicksburg, given by Hilgard $a$ as follows:

\section{Section of the bluff at Vicksburg.}

Feet.

7. Bluff formation (loess): $1 \dot{0}-20$

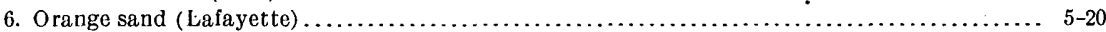

5. Alternating strata, 1 to 6 feet thick, of limestone and marl, containing the Vicksburg fossils and some bands of noneffervescent gray sand and clay ...............................6 $60-65$

4. Black lignitic clay and gray sand, with Ostrea gigantea, Corbula alta, Natica mississippiensis, Cytherea sobrina, Madrepora mississippiensis................................ 5

3. Gray or black lignitic clays and sand with iron pyrites; exuding salts and sulphureted hydro-

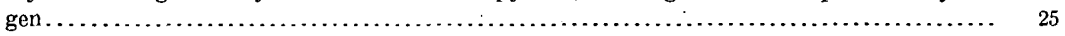

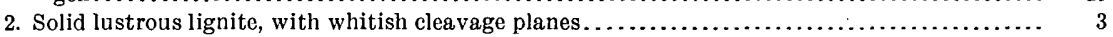

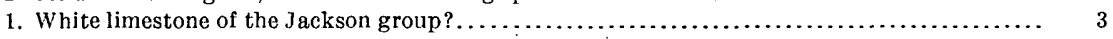

All above No. 1 Hilgard places in the Vicksburg.

To show the alternating character of the limestone and marl an additional section is given below of the bluff about halfway between the cemetery and the city:

\section{Section of the bluff near Vicksburg.}

Inches.

22. First stratum of limestone from top; overlain by loess $\ldots \ldots \ldots \ldots \ldots \ldots \ldots \ldots \ldots \ldots \ldots \ldots \ldots$

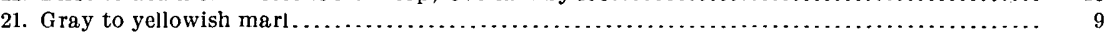

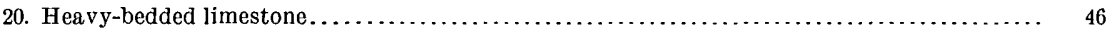

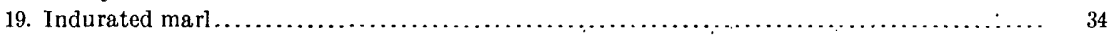

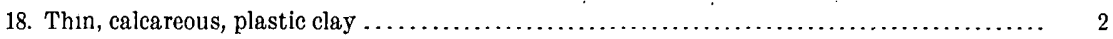

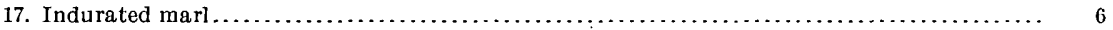

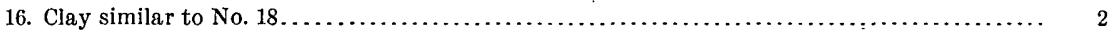

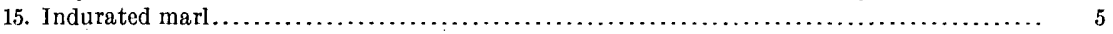

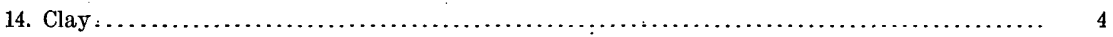

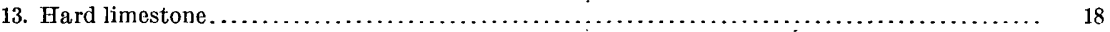

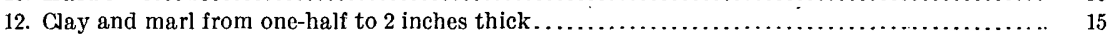

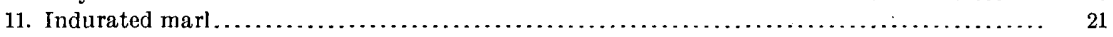

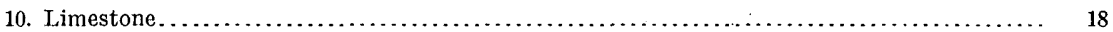

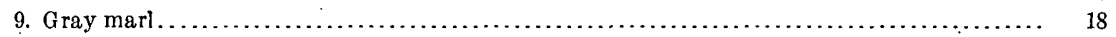

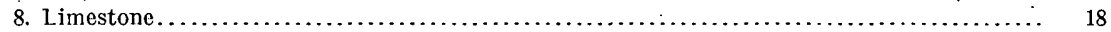

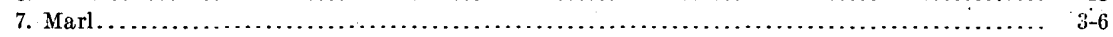

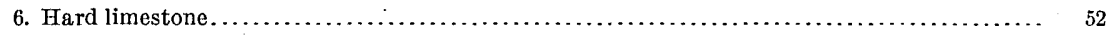

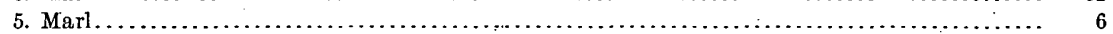

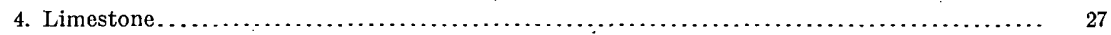

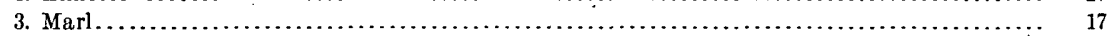

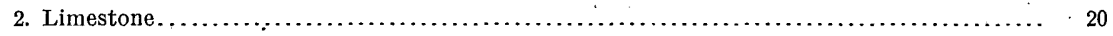

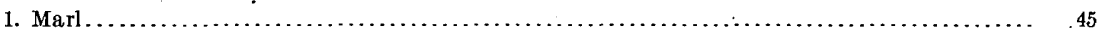

This exposure is charicteristic of the Vicksburg thiroughout the State. In places the limestone is more abuidant, and in other places the marl. The limestone is more commonly found on account of the ease with which the marl breaks down into soil. In fact, the marl is rarely found except on blufss, in wells, or on billsides where erosion has been very rapid. 
An interesting section occurs in the bluff 5 miles north of Vicksburg. The Yazoo and Mississippi Valley Railrond follows along the eastern edge of the Ynzoo bottom near the bluff. The railroad track here has an elevation of about 100 feet above tide. At 130 feet above tide the top of the Vicksburg limestone occurs in a deep ravine. Here, as at many other places along the bluff to Vicksburg, fine springs of water come out on top of the limestone, most of which is covered by the wash from the bluff. Instend of the top of the limestone becoming higher to the north it appears to have about the same clevation as at Vicksburg; if anything, the top here is lower than it is at the cemetery. Resting on the Vicksburg limestone are 50 feet of white, fine-grainied quart\% sind with spots of iron oxide through it, the whole showing distinct lines of stratification. This is doubtless the sand of the overlapping Grand Gulf. It is clearly not Vicksburg, and is very distinct from the overlying Lafinyette in the character of the sand and mamner of deposition. Above the white stratified sand are 50 feet of Lafayette sand and pebbles. The basil part of the Lafayette contains a large amount of yuartz and flint pebbles, stained with red oxide of iron. The pebble beds are not continuous, but appear in large lenses. 'The uppermost formation, capping the bluff, consists of about 90 feet of gray cilcareous loess filled with snail and various land shells.

The gulch in which the above formations are so well exposed is 190 feet deep and is washed out in the shape of a large amphitheater. The walls stand almost perpendicular, and a glance around the sides shows the gray loess at the top and the laminated white sands resting on top of the limesione, separated by the orange-colored Lafayette sand, which contains large lenticular deposits of pebbles.

The Vicksburg occurs in numerous places between Vicksburg and Byram, where lime was made from this rock as early as 1836 . The lime used in the first brick structure in Jackson is said to have come from the Byram kiln.

At the old Robinson quarry, about 4 miles southeast of Brandon, the following section of the Vicksburg was obtained:

\section{Section of Vicksburg forrnation 4 miles southeast of Brandon.}

Inches.

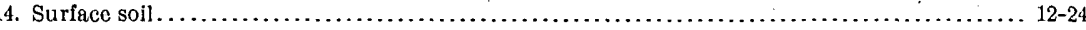

13. Ledge of limestone with edges of the rock rounded by the action of weathering agents..... 12

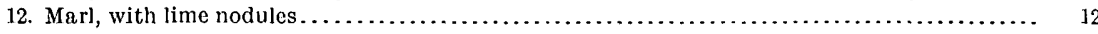

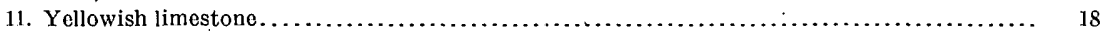

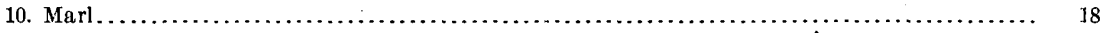

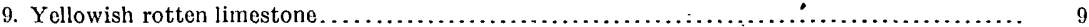

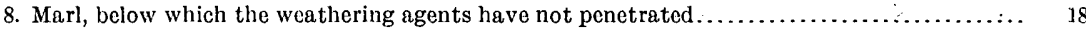

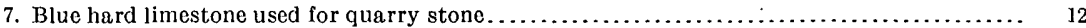

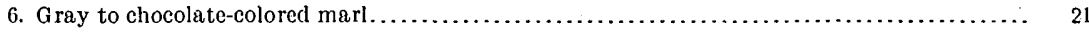

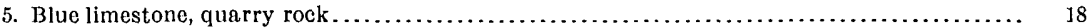

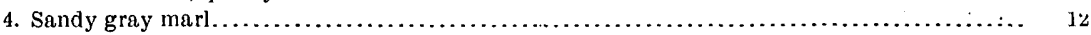

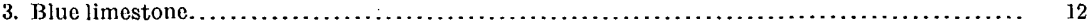

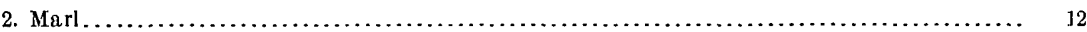

1. Limestone, bottom of quarry.

An interesting experiment was made with this rock to test the practicability of using the Vicksburg limestone as a building stone or for road metal. Machinery was installed for quarrying the rock and crushing it for the streets of Jackson. Work has been discontinued because, as reported, it was necessa:y to handle so much dead material to get the rock. The soil covering the rock will not average 2 feet thick, and the real difficulty is that the ledges of limestone, which average about $13 \frac{1}{2}$ inches thick, alternate with beds of indurated marl averaging $15 \frac{1}{2}$ inches, which is too hard or spongy to pick and not hard enough to blast. The ledges below No. 7 were used for road metal. Above this the rocks are soft and not suitable for this purpose.

In Smith County, still farther southeast of Brandon, the Vicksburg assumes a different phase from that which it presents to the west. South of Pineville the limestone is quarried from the ground and used locally for building chimneys and foundations for houses and barns. When first taken out of the quarry the stone is so soft that it can be sawed into any 
shape by hand. It is then left in the open air, where it soon becomes hard. It is in most places free from fossils and when dry is almost pure white.

At Vossburg the hard blue ledges of the lower Vicksburg occur in the hills one-half mile northwest of the town. To the northeast the low prairie land of the Jackson continues to near Pachuta.

On the Chickasawhay [says Filgard $a$ ], between Red Bluff and the latitude of Waynesboro, both marls and limestones crop out with frequency: the same is the case on the creeks on the east side, as on Cakcheys Mill Creek and Limestone Cree.r, especially near the mouth of the latter, at the foot of the hill on which Dr. E. A. Miller lives, the most southerly outcrop of the calcareous Eocene [now called Oligocene] on the Chickasawhay.

\section{PASCAGOULA FORMATION.}

Along Chattahoochee River in Florida a series of Oligocene beds overlain by a succession of strata containing Miocene fauna has been described by D. W. Langdon as Miocene. On paleontologic and stratigraphic evidence the.upper Oligocene beds have been shown by Dall $b$ and Stanley Brown to rest directly upon the lower Oligocene or Vicksburg limestone. The same Oligocene beds have been found by Dr. E. A. Smith on Conecuh River, near Roberts, Ala. Deep borings at Mobile, Ala., have shown the Oligocene beds at a depth of 1,550 feet below the surface.

Nowhere in Mississippi have the Miocene beds so far, been discovered. However, on the banks of Chickasawhay River, a few. miles above the mouth of Leaf River, L. C. Johnson has found a Tertiary bed of marl containing large oysters (Mactra lateralis Say), numerous small Gnathodon johnsoni, and other forms. These fossils were referred to Dr. W. H. Dall, who doubtfully correlated the bed with the aluminous clay horizon of the Alum Bluff section, which is placed in the Miocene.

The exact age of the bed has not been determined, but Mr. Johnson has given it the name Pascagoula and refers it to the Miocene.

Dr. E. A. Smith, who visited the locality later, in speaking of the fossiliferous bed, said:

It, at the type locality, is covered by the sands, with silicified tree trunks and lignitized wood belonging to what Hilgard called $G$ rand Gulf, but the material in which the shells are found may be the same blue clay assigned to the Grand Gulf, lower bed, and occurring along the bank of Chickasawhay River from Bucatunna down to its confluence with Leaf River. Whether, therefore, this Pascagoula bed belongs to the Grand Gulf or not, it is below a great mass of material that has never been questioned as being Grand Gulf. At Mobile this same shell bed is penetrated to a depth of 700 feet, or thereabouts, and several hundred feet above the Chattahoochee Miocene [now called Oligocene], which is reached at 1,550 feet. In Mobile County, as in Mississippi, this shell bed is below a great mass of sands and clays that have been considered Grand Gulf.

So, as a matter of fact, there come in between the Vicksburg and Lafayctte, both in. Alabama and Mississippi, a great series of marine Tertiary strata, of Miocene age, at least in the lower beds, and these marine Miocene beds and the Pascagoula (whatever its age may be) lie below much, if not all, of what Hil. gard designated as Grand Gulf, and what $I$ take it is actually Grand Gulf. As before mentioned, nothing is known to overlie the Grand Gulf beds older than the Lafayette, while the Grand Gulf is certainly known to overlie at least the Miocene, and, as many of us think, any other later Tertiaries if they exist along the Gulf border.

Owing to the limited area of outcrop the formation is not shown on the map.

\section{GRAND GULF GROUP.}

The Grand Gulf group, as the term is here used and mapped, is possibly not a homogeneous series of beds, but may include formations of different age. It is certain, however, that everything here included in the Grand Gulf is younger than the Vicksburg limestone and older than the Lafayette or "Orange sand" formation.

At the type locality of the Pascagoula formation, as well as at Mobile.and other points, the Pascagoula beds are overlain by Grand Gulf beds; but further field work will be required before the relation of these two series in other areas can be stated with certainty. Such 
Jater work may require a redefinition or limiting of the term Grand Gulf. At present, however, the term is here used in the sense in which it was proposed by Hilgard, for a particular series of clays and sands overlying unconformably the Vicksburg and other beds, and overlain in places by the Lafayette, Port Judson, and loess.

The Grand Gulf was first studied and named by Wailes from the type locality at Grand Gulf, Miss. He included in the Grand Gulf sandstone the interbedded clays, which he regarded as "the decomposed portions of the imperfectly formed rock." a

At Grand Gulf, the.type locality, at Mississippi Springs, and at Raymond, mentioned by Wailes, $b$ the sandstone occurs in ledges interbedded with white plastic clays. He further adds:

At many points within the scope I have mentioned the rock crops out.in the beds of the watercourses and upon the sides of the ridges, exhibiting, as in that in the Mississippi bluff, such an identity of character as to induce me to characterize it wherever met with as the Grand Gulf rock.

The sandstone of Fort Adams, or Davion rock, as it is called by Wailes-

is an argillo-siliceous composition of a dingy-white color in the mass, containing a small portion of sand, cemented together and tinged by a brownish-red metallic oxide, which pervades it in irregular and distorted veins and which, forming the hardest portions of the mass, gives the weathered surface a very rough and nodular character.

Wailes describes the Grund Gulf in T. 5 N., R. 1 E., near Wilsons Ferry, on Homochitto River, as follows:

The more compact arenaceous portion of the stratum is here about 3 feet in thickness, with about the same thickness, above and below, of the more argillaceous and crumbling material, which, in wet weather forms a very tenacious white pasty clay, rendering this a very formidable pass to the wagoners on the road, who have given to the ridge on which this ledge runs the name of the Devil's Backbone.

It is evident from the ahove quotations that it was the intention of Wailes, who first used the name Grand Gulf sindstone, to include in the term the clays of the same age.

At Star, Miss. (see p. 42), clays are interbedded with the sandstone and form the principal part of the Grand Gulf in some of the outcrops along the railroad track. Clays are likewise prominent in the Grand Gulf at Raymond, Byram, Florence, and numerous other localities originally included in the Grand Gulf area.

The Grand Gulf is made up of unconsolidated sands, siliceous and aluminous sandstones, and clays. The sandstones are usually white to light-yellowish gray in color, and but slightly cemented. They are composed of sharp grains of silica, with more or less clayey material and iron pyrites. Near the surface the oxidation of the iron pyrites in the sandstone gives it a spotted rusty to yellow color and renders it undesirable for a building stone. In places the sandstone is little more than a mass of indurated, uncemented sand which can be dislodged from its original bed with a spade. In other places it is much harder, even approaching a quartzite.

The sundstones interbedded with clays of this group are particularly common in the northwestern part of the aren-that is, north west of a line drawn from Fort Adams to Raleigh; southeast of such a line sandstones are very rare, and the group consists of bluish to black clays (in places almost shales) ind clayey sinds.

Throughout the Grand Gulf, particularly in the northwestern or sandstone area, crystallized gypsum and common salt, with more or less magnesian salt, are often found. "This," says Doctor Hilgard, $c$ "is the case, even with many of the solid sandstones, which on exposure to the weather become covered with efflorescences of salts; and it is to this peculiarity, no doubt, that their want of durability is to a great extent to be attributed."

The Grand Gulf underlies most of that part of Mississippi south of a line drawn as follows: Starting on Mississippi River a few miles south of Vicksburg, it runs parallel to and a mile or so south of the Alabama and Vicksburg Railway and passes a short distance north of Raymond. Here the boundary line between the Vicksburg and Grand Gulf bends rather abruptly

$a$ Wailes, Agriculture and Geology of Mississippi, 1854, p. 213.

$b$ Op. cit., p. 217.

$c$ Geology and Agriculture of Mississippi, 1860, p. 148. 
to the southeast, crossing the Illinois Central Railroad between Terry and Byram. The line then turns northeastward, passing through Monterey to Brandon, at which point it finally assumes a southeasterly direction, continuing thence through Daniel, Raleigh, Vossburg, and Waynesboro into Alabama. All of the State south of this line, except a narrow belt of Port Hudson clays, which border the Gulf coast in Hancock, Harrison, and Jackson counties, is occupied by the Grand Gulf group.

The thickness of this group is not definitely known, but from some deep-well records along the coast the drill is supposed to have penetrated the Grand Gulf at 750 to 800 feet. At this depth some fossils were found, which L. C. Johnson refers to the underlying Pascagoula marls.

Lincoln, Copiah, Hinds, Simpson, and Rankin counties, and the counties along Mississippi River from Fort Adams to Vicksburg, contain the only outcrops of the sandstone, which in these localities alternates with white to bluish plastic clays.

The following section from the type locality, Grand Gulf, is taken from Hilgard's Geology and $\Lambda$ griculture of Mississippi, page 148:

\section{Section of the bluff at Grand Gulf.}

12. Calcareous silt of the Bluff formation, forming the hilltops...................... $60-70$

11. Grand Gulf sandstone, in ledges 10 inches to 2 feet in thickness; stratification often diccordant

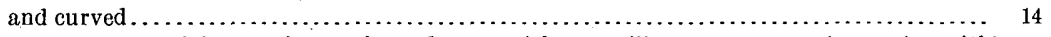

10. Gray sandy material, sometimes soft sandstone, with an argillaceous cement, alternating with harder ledges, 6 to 10 inches thick, of friable, whitish sandstone................... 15

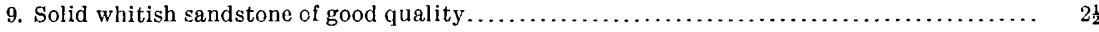

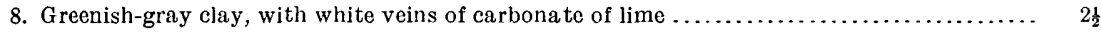

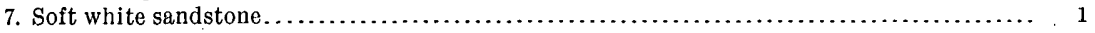

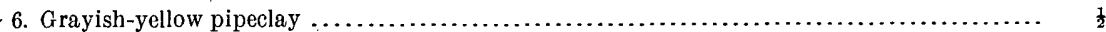

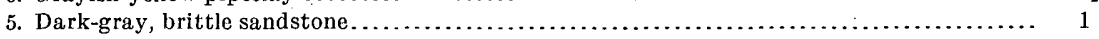

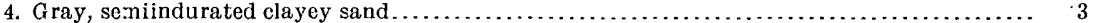

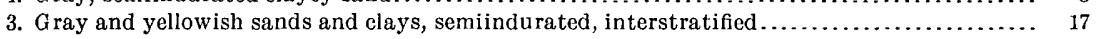

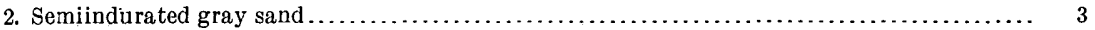

1. Greenish-gray clay, with veins of carbonate of lime..................................... 2

Doctor Hilgard mentions numerous other outcrops of Grand Gulf in this region, including several localities near Rocky Spring where beds of lignite occur. Wailes found a bed of lignite 2 feet thick between two ledges of sandstone; also in sec. 11, T. 4 N., R. 3 W., and at Par tins Ferry, Hinds County. Alternating beds of clay and sandstone are reported by Hilgard at Fayette, Jefferson County, also in Franklin, Copiah, Hinds, Rankin, and Simpson counties.

The following section from a bluff on the south side of Richland Creek, in sec. 12, T. 4 N., R. 2 E., shows the character of the lower 100 feet of the Grand Gulf:

Section of Grand Gulf beds in sec. 12,T: 4 N., R. $2 E$.

4. - Ledges of Grand Gulf sandstone, 12 to 15 feet thick, alternating with gray clays on side of hill. (?) 50

3. Dark-blue plastic clays, containing more or less sand and becoming lighter colored near bottom

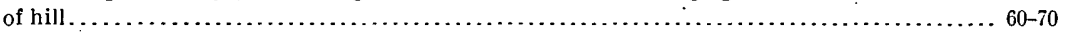

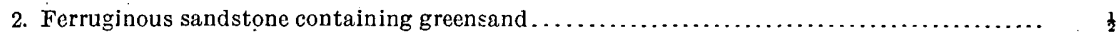

1. Calcareous greensand marl, with badly preserved fossils, extending to bed of creek ......... 5

The ledge of ferruginous sandstone marks the division between the Grand Gulf and the underlying Vicksburg. Similar outcrops showing the lower clayey portion of the Grand Gulf overlying the Vicksburg.formation were seen 1 mile south of Pearson, Hinds County.

A section of the Grand Gulf at Star, Rankin County, is very similar to that at Grand Gulf. The sandstone comes to the surface in the hills at and near Star. In the railroad cut 100 yards south of the station there are 5 feet of soft rotten sandstone with harder layers from 3 to 6 inches thick through it. This is overlain by about 10 feet of gray to white plastic clay containing some sand. The following section was obtained in the hills to the southwest, where the material is at a higher elevation than the outcrop along the railroad: 
3. Heavy-bedded sandstone, in places barely cemented together so that great caves have been made in the hill by the action of weathering agencies................. Thickness undetermined.

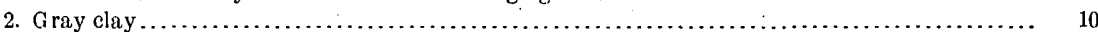

1. Fard white sandstone with bluish streaks through it. In places the stone is very compact and will take a slight polish. The larger part of it, however, is a loosely cemented, coarsegrained sandstone containing a small amount of mica and small irregular particles of clay which were washed into the matrix before it was hardened. The clay particles seem to have

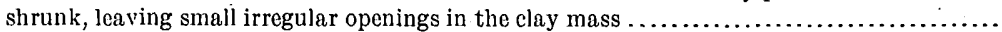

Two specimens of this sandstone were tested in the engineering laboratory of Purdue University with the following result:

\section{Cmushing strength of Grand Gulf sandstone from Star.}

Pounds per square inch.

Sample No. 1, 4 by 4 inches. 2,740

Sample No. 2,4 by 4 inches........................................................ 3,260

South and east of the line above mentioned the sandstones are wanting and the formation is essentially a series of indurated, laminated clays and sands of various characters, from the white plastic pottery clays to the less pure lignitic and gypsiferous ones containing lignitized tree trunks and in places beds of pure lignite.

Four outcrops of Grànd Gulf clays on Chickasawhay and Pascagoula rivers are mentioned by Doctor Hilgard. The northernmost of these is on Col. Sam Powe's place, 2 miles south of Winchester, Wayne County. At this locality are well-preserved lignitized trunks of trees and old stumps which have been covered with the "ancient soil" absolutely on the spot where they grew. Above the old trunks and stumps are thin seams of sandy clay, between which are successive layers of leaves. The whole is covered with 20 feet or more of Lafayette sand. Most of the submerged trees, according to Hi lgard, are dicotyledons; some are coni fers and some palms.

To the west from Chickasawhay River a very plastic clay immediately underlies the Lafayette sands and overlies the darker lignitic clays as found along the river. This plastic clay is found in numerous wells beneath the Lafayette and likewise outcrops along the streams where the Lafayette has been removed. Deposits of leaves and vegetable matter similar to those mentioned above were observed by L. C. Johnson along Leaf River near Augusta, at Rawles Springs in the northwestern part of Perry County, and at Carpenter Bluff, Perry County. At the last place the Lafayette, according to Johnson, overlies about 50 feet . of gray sandy clays, below which are 14 or 15 feet of blue mud filled with leaves and rotten logs.

One and a half miles north of Hattiesburg, on the Gulf and Ship Island Railroad, the clay is characteristically developed. It is here very plastic, free from sand, and varies in color from white to blue, gray, and cream. It is nonfossiliferous and free from any lime concretions. It is very similar to the clay farther west along Pearl River; except that the latter clay has numerous lime concretions through it.

Below the variegated plastic clay so common at the surface at. Hattiesburg the strata contain more or less sand, lignitic material, and plant remains. Ferruginous nodules and in places more or less iron pyrites and numerous salts are present, which give rise to a great variety of mineral springs and inferior well waters.

The plastic Hattiesburg clay passes underneath the younger formations to the south. In some of the deejp wells along the coast a bluish-green plastic clay, with a maximum thickness of 150 feet, is reported to be struck from 450 to 550 feet. Whether this is the same clay as that coming to the surface at Hattiesburg it is impossible to say. With a southward dip of the strata of 6 to 8 feet per mile the base of the Hattiesburg clays would be penetrated at Mississippi City at a depth of about 600 feet. It has not been possible with the present data to ascertain the southward dip of the Grand Gulf, but it is very probable that 7 to 10 feet per mile is an average estimate. Regarding the dip of the Grand Gulf Hilgard $a$ said that " the 
position of the Grand Gulf strata can rarely be shown to be otherwise than nearly or quite horizontal on the average, although in many cases faults or subsidences have caused them to dip, sometimes quite steeply, in almost any direction."

After a study of the Grand Gulf strata along Chickasawhay River north of its confluence with Leaf River Doctor Smith, in an unpublished essay on the later T'ertiary strata, reaches the conclusion that there is but little, if any, dip to the Grand Gulf. He further says, however, that the calcareous strata outcropping on the Chickasawhay a few miles above the mouth of Leaf River and bearing Miocene fossils at the base of the lignitic clays which Hilgard called Grand Gulf, are found in a well at Mobile at a depth of 700 feet. The confluence of these two rivers is but about 25 miles north of the latitude of Mobile. On this evidence, therefore, and apparently somewhat at variance with the statement made by Smith that the strata along the Chickasawhay "are nearly or quite horizontal," there is a southward dip of at least 20 feet to the mile, ample allowance being made for difference in elevation of the two places. A much greater southward dip is obtained from beds containing Miocene fossils on Chattahoochee River, extending from Chattahoochee Landing down to Alum Bluff. "The Chattahoochee. Miocene [Oligocene of this paper] beds," says Smith, "outcrop at least in one place in Alabama, viz, on Conecuh River, in Escambia County, above Roberts, and about Roberts post-office. But deep borings in Mobile (30 miles south of Roberts) have shown that the very same beds that occur along Chattahoochee River lie at a depth of 1,550 feët, more or less, below the surface. Many well-preserved shells brought up from this depth afford ample proof of this." If the Miocene beds continue westward across Alabama from Chattahoochee River, which is very. probable, the southward dip is thus something like 50 feet to the mile.

It seems probable, then, that there is a very steep southerly dip to the older Tertiary, including the Chattahoochee Oligocene and overlying Miocene beds, but that on coming upward to the Grand Gulf strata the southerly dip has almost and in some places entirely disappeared. The deposition of the Grand Gulf strata did not immediately follow that of the Miocene beds, but there is a marked unconformity and a long time interval between the two. There was a marked subsidence of the land during the early part of the Grand Gulf period, so that Grand Gulf strata overlapped not only the Miocene beds, but likewise the Vicksburg, Jackson, and Claiborne, and extended the blanket far to the north, in places overlapping the Cretaceous.

Smith, in the above-mentioned essay, says that-

Hilgard saw no contact of the Grand Gulf along its northern border with anything below it other than the Vicksburg; but in Alabama, to the east of the Loulsville and Nashville Railroad, the northern . border of this formation takes a turn toward the northeast, and I have seen it resting on not only Vicksburg, but in turn on the Claiborne, on the Buhrstone, ard on the Lignitic formations, even the lowest of them at Clayton, in Barbour County; and farther east in Barbour County and stıll more in Georgia the Grand Gulf beds lap over well upon the Cretaceous beds. Certainiy, therefore, the order of succession going southward can not be taken as determining the geologic succession:

In A labama the blanketing character of the formation is very clearly seen, for in the different parts of the northern border of its occurrence erosion has exposed the underlying Tertiary beds, which are Vicksburg, Claiborne, Buhrstone, Lignitic Clayton, and even Cretaceous, according to the locality. Farther south erosion in similar manner has exposed the underlying Miocene [Oligocene] in the vicinity of Roberts, Ala., and along Chattahoochee River. We may state further that at Mobile, where the Grand Gulf beds occupy the surface, capped. it is true, with the Lafayette, the deep wells have demonstrated the existence at 700 feet below the surface of the Pascagoula bed and at 1,550 feet the Chat tahoochee Miocene [Oligocene], fully determined by the well-preserved shells. At present, then, the map of Mississippi must remain, as regards the Grand Gulf, practically as Hilgard has given it, with the understanding that the other marine Miocene deposits in all probability underlie and are hidden by it as by a blanket.

\section{QUATERNARY.}

LAFAYETTE FORMATION.

The Lafayette formation was first described by Hilgard in his Geology and Agriculture of Mississippi, in 1860, under the name of Orange sand. The name had previously been used by Safford $a$ of Tennessee, for the present Lafayette, but he included in it the present Wilcox 
and the whole was referred to the Cretaceous. In $1891 \mathrm{~W} \mathrm{~J}$ McGee a published a paper on the Lafiayette formation. He likewise included in the term Lafayette 200 feet or more of the Wilcox which belongs to the Eocene. The vast deposits of pottery clays in the vicinity of Holly Springs, Miss., which contain numerous impressions of leaves of Tertiary plants, were improperly placed in the Lafayette by McGee. The term as used in this report is restricted to the thin veneering of iron-stained pebbles and sand which overlaps unconformably all the other formations of the State, from the older Paleozoic rocks along Tennessee River to and including the Grand Gulf group of the late Miocene, and underlies the Port Hudson in southern Mississippi. In age it is, therefore, between the Grand Gulf and the Port Hudson and loess. In the south the Lafayette is overlain by the Port Hudson clays, while in northern Mississippi the loess, when present, rests directly on the Lafayette, and the Port Hudson is absent. East of the typical calcareous loess in western Mississippi the yellow loam or upper member of the loess immediately overlies the Lafayette. In the central and eastern parts of the State, where not carried away by erosion, the Lafayette occupies the surface, as the loess does not extend more than 100 miles from Mississippi River.

The Lafayette is a fresh-water deposit, which is composed principally of dark-red to laintorange, coarse, round-grained sand, and in places contains more or less clay and waterworn pebbles. The pebbles are of two kinds (a) chert and limestone containing numerous Paleozoic fossils, such as fenestellids, favosites, pentremites, and other forms; (b) less numerous but more resistant quartz pebbles. The former class is much more abundant. They were washed into the Lafayette waters from the adjacent Paleozoic hills, as their fossils clearly indicate. The nearness of their origin is further indicated by the angular character of the pebbles, some of them barely having their sharp corners worn off'. The quartz pebbles are all round or egg-shaped and are much smaller than those of Paleozoic origin. They have been transported over a greater distance and are consequently more worn. They are doubtless the fragments of the great northern drift carried southward by great volumes of cold, fresh water at the close of the Glacial epoch.

The thickness of the formation varies from a knife-edge to 50 feet. The latter, however, is very rare. It is more often found to be less than 10 feet thick.

In Tishomingo and Itawamba counties the Lafayette contains large deposits if waterworn pebbles of flint, chert, and quartz. Another belt of similar material, but somewhat different in the shape of the pebbles, occurs along the eastern edge of the loess formation, comprising the counties of De Soto, Tate, and Yalobusha. The pebbles of the northeastern area are oblong or egg shaped and contain more quartz, while those of the western area are worn into a more rounded form. Still another belt, which is practically a prolongation of the western belt, is found in the southern part of the State, the main line of the Illinois Central Railroad following along the outcrop of the gravel beds from Jackson to the Louisiana border.

The Lafayette was deposited upon a deeply eroded surface of the older formations, which accounts in part for the irregularity of its thickness. In some places gullies and ravines, cut in the old formations and filled with Lafayette, have been exposed. Since the deposition of the Lafayette there has been a large amount of erosion and in many areas the whole formation has been removed. In the Selma chalk and Porters Creek areas the Lafayette is generally absent, when present it occurs in small isolated-patches. East of the Selma chalk area there is more or less Lafayette covering the Eutaw and Tuscaloosa and overlapping onto the Carboniferous. In northern Mississippi, particularly in Marshall and Lafayette counties, where the formation was first described and named, the Lafayette, when present, is but a few feet thick, but in most places it is wanting. It thickens to the south, reaching its maximum thickness, said to be 200 feet, in southern Mississippi. No such thickness, however, was observed in the course of the present work.

In various localities over the State the iron in the Lafayette has cemented the yellow or red sands into a ferruginous sandstone, which contains more or less iron and is often mistaken for pure limonite or brown hematite. These deposits are in every case of very shal- 
low depth, but often extend over large areas. The ferruginous sandstone is always formed immediately above a bed of clay or some material which checks the downward flow of water. The water passing through the Lafayette takes up iron oxide in solution, and being checked by the underlying impervious bed deposits the iron oxide, thus cementing the sands into a compact mass. This mass is constantly increased by the addition of more iron from the iron-charged waters. Gradually the overlying material is carried away until the ferruginous sandstone is reached; this resists the action of erosion and forms a scarp on the tops and sides of many hills.

Where the Lafayette is thick it is the source of a very desirable and easily accessible supply of potable water. The great amount of sand in the formation forms a natural filter for the water. Many of the springs and the shallow wells of the State derive their water from the Lafayette.

\section{PORT HUDSON FORMATION.}

In the American Journal of Science, volume 47, 1869, page 79, Doctor Hilgard first described the Port Hudson formation at the type locality, Port Hudson, Miss. The following sections were made by him along the river near the town:

Sections of Port Hudson formation near Port Hudson.

\begin{tabular}{|c|c|c|c|c|}
\hline \multirow[b]{2}{*}{ No } & \multicolumn{2}{|l|}{ Near sawmill, Port Hudson. } & \multicolumn{2}{|c|}{ Midway between Port Hudson and Fontania. } \\
\hline & Material. & $\begin{array}{l}\text { Thick- } \\
\text { ness. }\end{array}$ & Material. & $\begin{array}{l}\text { Thick- } \\
\text { ness. }\end{array}$ \\
\hline 6 & Yellow surface loam....... & $\begin{array}{r}\text { Feet. } \\
4-6 .\end{array}$ & Yellow loam, sandy below.............. & $\begin{array}{l}\text { Feet. } \\
\quad 8-10\end{array}$ \\
\hline & & & White and yellow hardpan ............... & 18 \\
\hline 5 & Yellow hardpan..... & 25 & $\begin{array}{l}\text { ruginous sandstone, irregularly strati- } \\
\text { fied. }\end{array}$ & $8-15$ \\
\hline 4 & Heavy greenish clay $\ldots \ldots \ldots \ldots \ldots \ldots$ & $\cdots$ & Heavy greenish or bluish clay ............ & 7 \\
\hline 3 & $\begin{array}{l}\text { Gravel, sand, and clay in irregular } \\
\text { bands, like river alluvium; with } \\
\text { pebbles, driftwood, leaves, and } \\
\text { mastodon bones. }\end{array}$ & 6 & White indurated silt or hardpan..... & 18 \\
\hline 2 & $\begin{array}{l}\text { Heavy greenish or bluish massy clay, } \\
\text { similar to No. } 4 \text {. }\end{array}$ & 25 & $\begin{array}{l}\text { Heavy green clay, with porous calcareous } \\
\text { concretions above, ferruginous ones be- } \\
\text { low; some sticks and impressions of } \\
\text { leaves. }\end{array}$ & 30 \\
\hline 1 & & & $\begin{array}{l}\text { B rown muck and white or blue clay, with } \\
\text { cypress stumps. }\end{array}$ & $3-4$ \\
\hline
\end{tabular}

At the stage of extreme low water[says Hilgard] prevailing at the time, the stump stratum (No. 1) was visible to the thickness of 10 feet at its highest point, showing several generations of stumps above one another, also the remnants of many successive falls of leaves and overflows. The wood is in a good state of preservation; no prostrate trunks are to be seen at present.

The main clay deposit (No. 2) varies but little in general character; although very solid, its tendency to cleave into prismatic forms renders it very liable to "cave " into the river. The upper portion of the stratum, especially. near its southern end, contains strings of calcareous nodules, on stratification lines 8 to 12 inches apart. No fossils save rare impressions of leaves.

No. 3 is exceedingly variable. At the northern end of the outerop it is a narrow band of swamp deposit; at the first of the profiles given it bears the character of a sandbar; lower down it returns to that of a swamp deposit; still below it is represented by a fine white silt, without a trace of vegetable remains. - Lower down again a Jignitic layer appears at its base, with leaves and fruit of living species of lowland trees; while near Fontania it is again a sandbar, with an abundance of prostrate trunks of driftwood, coarse sand, and pebbles.

The green clay stratum (No. 4) varies little, either in thickness or composition, and, like the stump stratum (No. 1), forms a convenient level of reference.

The hardpan (No. 5) I conceive to be the more immediate representative of the loess proper, with which it is connected by gradual transition, though at times greatly resembling some of the materials of the Lafayette. It is void of fossils. 
Doctor Hilgard and others regarded the clays and sands of the Yazoo delta as belonging to the Port Hudson formation; likewise deposits bordering on the Gulf coast. In correlating the outcrop at Port Hudson with the material of the Yazoo delta, he further adds:

The stump stratum (No. 1), however, as appears from numerous data collected by myself or contained in Humphreys and Abbot's Report on the Mississippi River, exists at about the same level - that is, near that of tide water-not only over all the so-called delta plain of the Mississippi, but also higher up, perhaps as far as Memphis, and all along the Gulf coast, at least from Mobile on the east to the Sabine River. Wherever circumstances allow, the overlying clay stratum (No. 2) is also observed.

In the report on the Coastal Plain of Alabama, page 40, Dr. E. A. Smith, in speaking of the eastward extension of the Port Hudson along the Gulf coast, says:

Whether there is any real genetic difference between the loess and the Port Hudson other than the order of deposition, the lowest and therefore the oldest members of this section have received the latter designation and there is no good reason for discussing it here and seeking change. It is these members from 1 to 4, inclusive [of the Port Hudson sections of Hilgard], that we find spreading along the northern shore of Lake Pontchartraị and underlying the alluvium of Pearl River, modified and reappearing beyond, and underlying and constituting the terrane of all the region of the "Pine Meadows," together with a variable fringe to the northward, covered by washings from the sand hills, and an undefined portion of the territory covered by the coastal sands, above more definitely called "Biloxi."

From Hilgard's sections there is little room for doubt regarding the order of deposition of the Port Hudson and the overlying loess. In both sections, made from two localities 1 mile apart, there is practically the same order of strata, with the loess or hardpan above what he describes as Port Hudson proper.

As will be seen from the above quotation, Smith has suggested the possibility that the entire section, as given by Hilgard, belongs to the loess and that the lower portion has received the name Port Hudson.

The section as above given is clear enough as it stands and shows the relation of the Port Hudson to the loess; but the correlation of the so-called Port Hudson of the upper Mississippi or Yazoo delta offers some difficulties which have not at present been removed. This correlation has been made chiefly from the fact that there are logs and decayed vegetation found in the clays of the Yazoo delta, and likewise calcareous concretions. The decayed logs, or "stump stratum," according to Hilgard, occur at about tide level throughout the Yazoo delta as well as farther south. At Port Hudson, Miss., the loess rests directly upon the Port Hudson formation, but farther north the loess caps the hills on the east rim of the Yazoo delta at 100 feet or more above the so-called Port Hudson. Finding the Port Hudson clays in the bottom and the loess on the east rim of the Yazoo delta 100 feet higher would, according to Hilgard's theory, necessarily imply that the entire Mississippi Valley contained at one time 100 feet more of Port Hudson than it does to-day. Succeeding this was a time of vigorous degradation, carrying away the loess and 100 feet of Port Hudson, until the present level was reached. This would mean that the vast bottom land in northern Mississippi, northeastern Arkansas, and Louisiana attained its present surface form by destructional rather than constructional agencies.

The Yazoo delta and the corresponding areas on the west side of the Mississippi, previous to the deposition of the present materials, were scoured out 50 to 100 feet deeper than they are at present. This is clearly proved by finding old logs, bark, and river gravels at these depths: The loess, Port Hudson, Lafayette, and portions of the Tertiary were removed by degradation. Then began the deposition which has continued until the present level has been attained.

A study of these later formations in northeastern Arkansas during the spring of 1905 has revealed the fact that the present levels of this vast plain have been reached by a constructional and not by a degradational agency. Much of the so-called Port Hudson of the lowlands appears to be the reworked products of the loess, which still caps the adjacent hills and Crowley Ridge.

If the materials of the Yazoo delta are considered to be Port Hudson, then, from the order of the strata in the south, the Lafayette must underlie it. While gravels are found at various depths in the wells over the delta, they do not resemble the typical Lafayette pebbles on 
the hills to the east. The pebbles found in wells throughout the delta are generally small and white, while those of the Lafayette are invariably iron stained and often quite large. The interpretation resulting from the present survey is that the vast so-called "Port Hudson" deposits of the Yazoo delta are of much more recent date than the Lafayette, Port Hudson, loess, and yellow loam, and are, to a greater or less degree, the reworked products of these formations.

LOESS.

This highly interesting formation was first recognized in this country along the lower Mississippi by Sir Charles Lyell in 1846. In 1854 Wailes, in the report on the Agriculture and Geology of Mississippi, mentions the loess as occurring at various places along the Mississippi. The following year G. C. Swallow, State geologist of Missouri, described the loess of Missouri River and gave it the name of Bluft formation. Hilgard used the same term for the loess in Mississippi in 1860. It has since received the attention of Chamberlin and Salisbury, McGee, Mabry, Binney, and Shimek. The latter, in Bulletin No. 4, vol. 5, of the State University of Iowa, presents a lengthy discussion of the loess at Natchez, Miss., ascribing its origin to æolian agencies. His conclusions are based entirely on the fauna found in the loess. At Natchez and Vicksburg, the two localities where he saw the loess, he found the material a highly calcareous, homogeneous mass, nonstratified and containing numerous land snails and other terrestrial forms.

The loess is divisible into two distinct parts-(a) the fine, calcareous, gray to buff-colored, silty clays, containing numerous lime concretions and iron tubules, besides a great variety of fresh-water and land shells; (b) noncalcareous yellow to brown loam, void of shells. The latter has been described by Hilgard as the yellow loam.

The hypsometrical relation of these two members varies in different places, as the following will show. Shimek $a$ says:

The loess [at:Natchez] is uniformly the uppermost deposit, forming the immediate subsoil on the ridge on which. Natchez is located. Underlying it in most of the exposures is the yellow or brown loam, which closely resembles loess, but is not fossiliferous and is usually of a deeper red color, though sometimes practically indistinguishable from it.

In northern Mississippi Hilgard describes the yellow loam as overlying the loess. McGee places the yellow loam above the calcareous loess, but adds:

The order of the first two members might be reversed with equal propriety in the southern portion of the embayment; for the loess is but a phase of the loam and is frequently underlain as well as overlain by the loamy deposits.

Mabry refers to the yellow loam and loess as being not only homotaxial but synchronous as well.

From observations made at various places in Mississippi, Tennessee, and Arkansas, the writer has reached the conclusion that all the above statements are correct. The yellow loam is only a modification of the typical loess. In other words, the loess changes in character from a gray, calcareous, silty material filled with shells to a reddish or yellow clay free from shells and calcareous matter. The positions of the two are interchangeable. At numerous places along Crowley Ridge, in Arkansas, the yellow clay both underlies and overlies the typical calcareous loess, but there are no lines of division between the two; one grades insensibly into the other.

In the vicinity of Bolton, Miss., and along Big Black River it is often impossible to draw any line where the loess ends and the yellow loam begins. The calcareous loess gradually blends upward into the more clayey loam.

It is frequently the case that the yellow loam is entirely wanting, as at Helena, Ark., where the entire bluff is capped with the fossiliferous calcareous loess, which here shows faint lines of stratification. Still farther north, along Crowley Ridge, in Arkansas, the calcareous loess is wanting and the buff to yellow clay is at the top of the bluff overlying the Tertiary. 
The loess is found skirting the east bank of Mississippi River south of Vicksburg and to the north bordering the bluffs which form the eastern rim of the Yazoo delta. The deposit is thickest near the river and gradually thins out to the east, finally disappearing entirely. In some of the hills east of Grenada the loess or yellow loam covers the sides and base of the hills, but does not reach to the top. The hills thus stand out like islands, surrounded by loess sediment.

Where characteristically developed, as at Vicksburg, Natchez, and Yazoo City (Pl. III, $B$, p. 18), the calcareous portion of the loess has the tendency to stand up in perpendicular walls for long periods of time.

In northern Mississippi the upper, nonfossiliferous yellow clay loam extends 50 miles or more east. of the Yazoo bluffs. It forms the highest stratum as far east as Marshall and Lafayette counties and overlies the Lafayette when present. Only the lower member is shown on the map.

\section{RECENT ALLUVIUM.}

The most recent deposits of the State, coccurring along the present streams, are not shown on the map, but have been mapped with the underlying formations.

\section{MINERAL RESOURCES OF MISSISSIPPI.}

\section{PRESIENT' DEVELOPMENT.}

The development of the mineral resources of Mississippi has been so slow that the total annual mineral product of the State is still of little importance compared to her vast agricultural output. The most accurate figures obtainable show that for the past four or five years the annual mineral production of Mississippi has varied from about $\$ 500,000$ to about $\$ 700,000$. About nine-tenths of this production comes from the clay-working industriesbricks, tiles, stoneware, and pottery. ${ }^{\circ}$ Next in importance at the present time are the mineral waters of the State, which contribute materially to her production. A small amount of stone is quarried within her limits, and comparatively unimportant amounts of ocher, glass sand, iron ore, etc., have been shipped at various times.

\section{FUTURE PROSPEC'IS.}

The slow development of the mineral resources of the State is due, in large part, to the fact that no State geological survey has been in existence. It is known that Mississippi pos- sesses, for example, large deposits of excellent raw material on which to base very extensive cement and clay-working industries. These deposits have never been accurately mapped or tested, however, and so little is known concerning the actual cistribution and composition of these raw materials that capital is naturally averse to taking chances in developing them. The energetic prosecution of a State survey would have the effect of advertising the presence of such resources and of determining accurately their distribution, their quality, and their uses.

Aside from the clay and cement resources of Mississippi, several other mineral products would seem to promise future importance. Deposits of iron ore are known to occur, and tests of their quantity and quality would be of great value to the State. Ocher, glass sand, tripoli, and fuller's earth occur, apparently in deposits of workable size. The lignites of the State are worthy of attention, particularly for local use in clay works, etc.

Aside from iron, no metallic ores are known to occur in Mississippi in deposits of workable size, and the prospect of finding such deposits seems very poor.

The calcareous and greensand marls of the State deserve study, particularly in view of the great importance of Mississippi as a cotton producer. At present every pound of fertilizer used on Mississippi fluntations is imported from other States. It seems probable that much of this importation could be avoided by the development of the local greensand marl deposits, some of which carry appreciable percentages of phosphoric acid.

Bull. 283-06-4 


\section{CLAYS AND CLAY INDUSTRIES.}

The most important mineral industry of Mississippi is that based on her clay resources. The clay industries are, as yet, not so well developed as the abundant supplies of good clays would justify. This lack of development is due, in part, to lack of published information regarding the variety and extent of the clay deposits of the State, though difficulties in regard to transportation and markets have also retarded the growth of these industries. Recent and prospective improvements in railroads and the steady growth of the villages and cities of this section will dopbtless aid greatly in advancing the brick and pottery industries of Mississippi.

According to the statistics collected by the United States Geological Survey, the clay industries of Mississippi during the years 1900 to 1904, inclusive, produced brick and pottery valued as follows:

Production of pottery and brick in Mississippi, 1900-1904.

\begin{tabular}{|c|c|c|}
\hline Year. & Potiery. & Brick. \\
\hline $1900 \ldots \ldots \ldots \ldots \ldots \ldots \ldots \ldots \ldots \ldots \ldots \ldots \ldots \ldots \ldots \ldots \ldots$ & $\$ 14,452$ & $\$ 558,916$ \\
\hline $1901 \ldots \ldots \ldots \ldots \ldots . .$. & 4,779 & 451,694 \\
\hline $1902 \ldots \ldots \ldots \ldots$. & 14,424 & 501,785 \\
\hline $1903 \ldots \ldots \ldots \ldots \ldots \ldots \ldots \ldots \ldots \ldots \ldots \ldots \ldots \ldots \ldots \ldots$ & 14,295 & 658,491 \\
\hline $1904 \ldots \ldots \ldots \ldots \ldots \ldots \ldots \ldots \ldots \ldots \ldots \ldots \ldots \ldots \ldots \ldots \ldots \ldots$ & 14,701 & 710,878 \\
\hline
\end{tabular}

During 1903, according to the statistics gathered in the recent geologic survey of the State, 9 potteries and 86 brick plants were in operation; most of these plants were visited and samples of their clays and product were placed on exhibition at the St. Louis Exposition. In 1904 there were 92 plants reported as engaged in the clay-working industry.

The clays of the. State can be described most conveniently under nine headings, according to the geologic groups in which they occur. These are as follows: (1) Clays of the Tuscaloosa formation (lower Cretaceous); (2) Porters Creek clays (lower Eocene); (3) clays of the Wilcox formation (Eocene); (4) clays of the Jackson formation (upper Eocene); (5) clays of the Grand Gulf group (Miocene?); (6) Lafayette clays (Quaternary); (7) loess and yellow-loam clays (Quaternary); (8) Quaternary clays of the Gulf coast; (9) Quaternary clays of the Yazoo delta.

In the description of the clays by formations the general rule will be followed, as far as possible, of naming them by localities from north to south.

\section{CLAYS OF THE TUSCALOOSA FORMATION (LOWER CRETACEOUS).}

The lower portion of the Tuscaloosa formation is largely made up of plastic clays ranging in purity from white kaolin to a common sandy brick clay. They have been used to a small extent in the manufacture of ordinary stoneware and fire brick, and some of the purer clays have been used successfully in making china ware.

They occur in horizontally bedded strata, often immediately overlain by the Lafayette sands. In the northern area of the Tuscaloosa the clays of this group outcrop very frequently along the streams where the thick mantle of Lafayette has been removed. Many of the clays immediately underlying the Lafayette are more or less discolored by iron oxide from the overlying formation.

Iuka clay.-At Iuka, Tishomingo County, and for 6 miles north occurs a pink to mottledpurple clay, highly plastic and free from sand. It is found at Lake Como, one-fourth mile east of Iuka, and in numerous branches to the east and north. In some places the clay resembles the bauxite of Arkansas. It has small round spots through it the size of a pea. These spots are much deeper red than the rest of the clay. The analysis given below shows it to be high in alumina and ferric oxide, which gives the clay its pink to red color. A large amount of this clay has been mined and shipped from Iuka for making paint. 
Analysis of Iuka clay, Tishomingo County.

[By W. F. Hand, State chemist.]

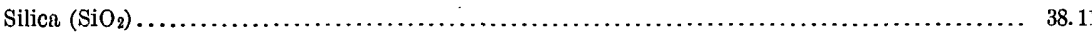

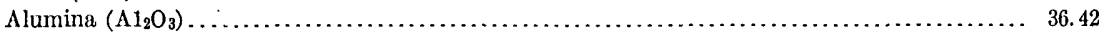

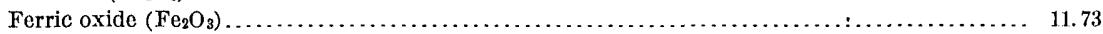

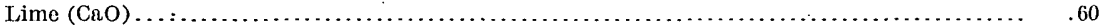

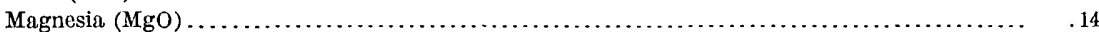

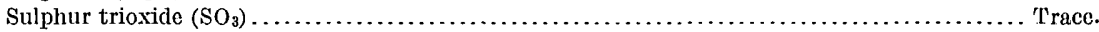

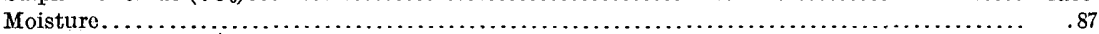

Loss on ignition $\ldots \ldots \ldots \ldots \ldots \ldots \ldots \ldots \ldots \ldots \ldots \ldots \ldots \ldots \ldots \ldots \ldots \ldots \ldots \ldots \ldots \ldots \ldots \ldots \ldots \ldots \ldots \ldots, 11.96$

99.83

Some of the clay from Lake Como was sent to the Newcomb Pottery in New Orleans and was made into ornamental vases. It was pronounced an excellent clay and the ware made from it shows it to be a product that is worth investigating. The clay. burns to a mottled pale red. The larger portion of the clays in the vicinity of Iuka are red to pink in color, but farther south they become whiter.

Turner clay.-In sec. 15, T. 4 S., R. 11 E., on the farm of James Turner, two samples of clays, one white and the other pink, were collected in a branch near the house: They are overlain by heavy beds of Lafayette pebbles and sand. At the place of outcrop the branch has cut into the hill, forming a small bluff, in which the clay appears. The pink clay is within 100 feet of the white clay and appears to be a continuation of the same bed. The clays are similar in texture, both free from sand and very plastic. The only apparent difference between them is that the pink clay contains a larger amount of ferric oxide. The following analysis shows the character of the white clay from the Turner place:

\section{Analysis of Turner clay, Tishomingo County.}

[By W. F. Hand, State chemist.]

Silica $\left(\mathrm{SiO}_{2}\right)$

66.85

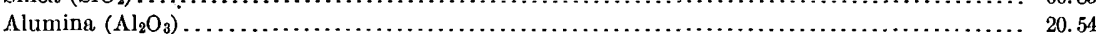

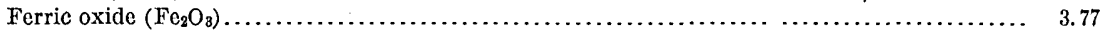

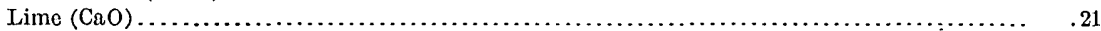

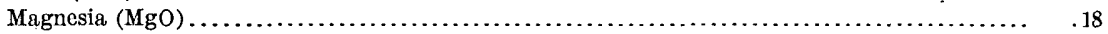

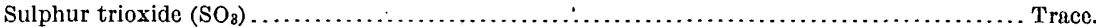

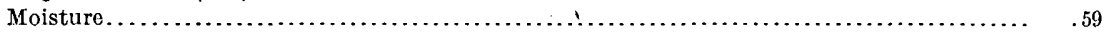

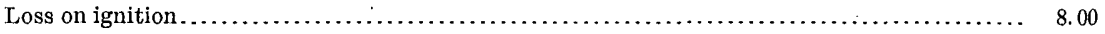

100.14

Still farther south Crippledeer Creek, which rises near the center of Tishomingo County and flows eastward into Bear Creek, has cut through the Lafayette and the overlapping Tuscilloosa, exposing the older Paleozoic rocks in its lower course. The cross section of the strata along this stream shows the clayey character of the lower Tuscaloosa.

P'ennywinkle clay.--On Pennywinkle Hill, in sec. 8, T.4 S., R. $11 \mathrm{E}$, is a white plastic clay, which is distinctly stratified. It is purest near the base of the outcrop and gradually passes upward into a less pure dark shaly clay. This is in turn overlain by a yellowish-gray sandy clay. At the top of the yellow clay is a thin band of ferruginated sandstone, on which rest the Lafayette sands. At the bottom of the section the white clay contains small rounded quartz pebbles.interbedded in the clay. This cliay has buen used for years for making stoneware. It burns to a light-cream color. The following is an analysis of this clay:

\section{Analysis of Pennywinkle clay, Tishomingo County.}

[By W. F. Hand, State chemist.]

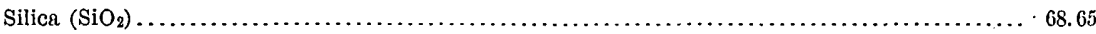

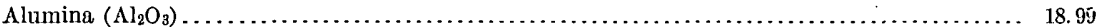

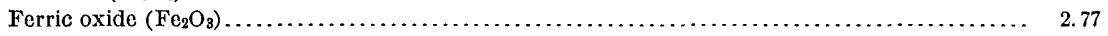

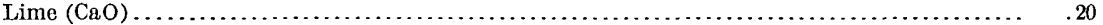

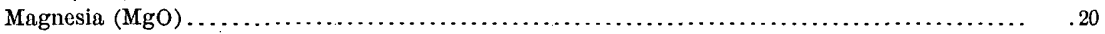

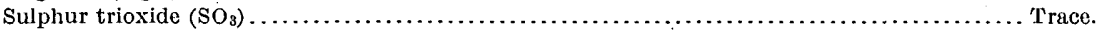

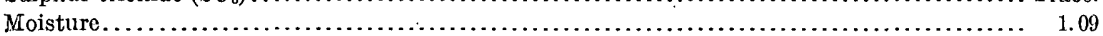

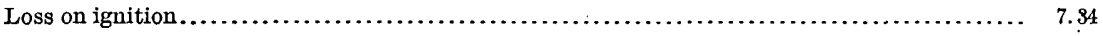


Coman clay.-A similar deposit of clay occurs on J. J. Coman's land in sec. 8, T. 4 S., R. 11 E. The analysis is as follows:

Analysis of Coman clay, Tishomingo County.

[By J. Blodgett Britton, of Philadelphia, $\mathrm{Pa}$ ]

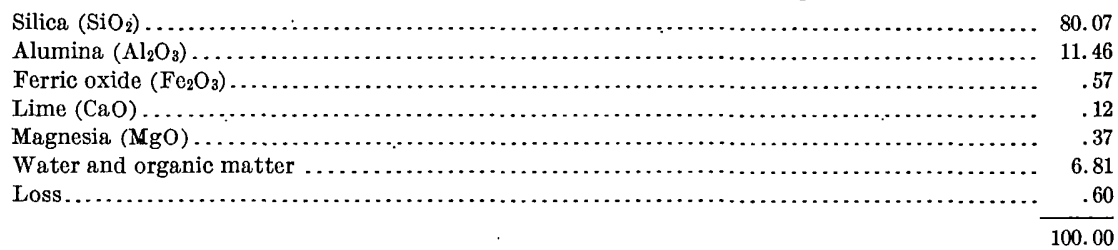

On the south side of Little Pennywinkle Creek the Tuscaloosa clay outcrops on the hillside at about the same elevation as the white clay on Pennywinkle Hill. The clay is of a much darker color than the latter and is highly stratified, almost approaching a shale. At the first bench of the hill the Lafayette has been entirely removed, leaving a large outcrop of the Tuscaloosa, which here is almost as black as lignite.

F'aden clay.-At the spring in front.of R. W. Paden's house in sec. 33, 'T. 5 S., R. 10 E., imnediately underlying the conglomerate at the base of the Lafayette a bed of very white Tuscaloosa clay outcrops. This clay is also exposed in a branch 100 yards west of the house and again one-half mile farther west. It appears in all the deep branches which have cut through the Lafayette in the above-mentioned section. This clay is reported to be 30 feet thick. Its outcrop is usually marked by bold springs of pure water, which has filtered through the overlying Lafayette sands and pebbles. Near the surface the clay contains more or less stains from the oxidized waters of the Lafayette. The following is an analysis of this clay:

Analysis of Paden clay, Tishomingo County.

[By W. F. Hand, State chemist.]

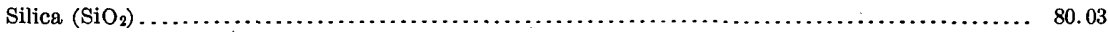

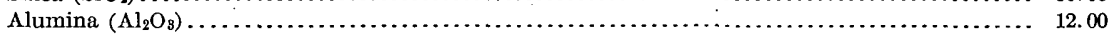

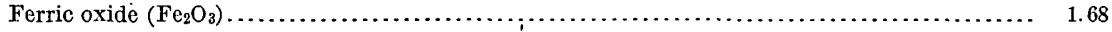

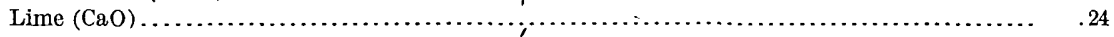

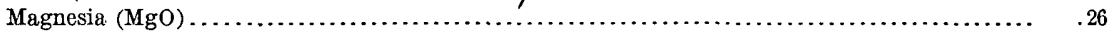

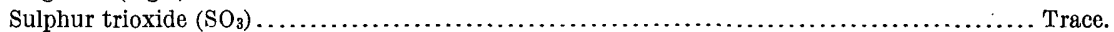

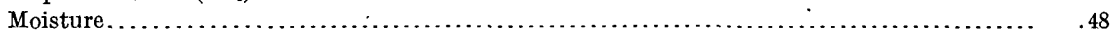

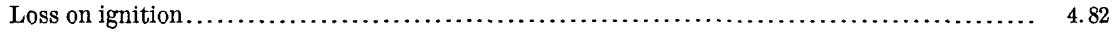

99.51

Clingscale clay.-On Mr. Clingscale's place, in sec. 8, T. 5 S., R. 11 E., Dr. E. W. Hilgard found a pure-white clay which was 30 feet thick. He obtained a specimen, and the following analysis shows it to be more free from magnesia, lime, and iron oxide than the Paden clay.

Analysis of Clingscale clay, Tishomingo County.

[By Dr. E. W. Hilgard.]

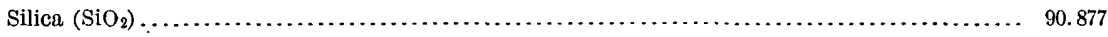

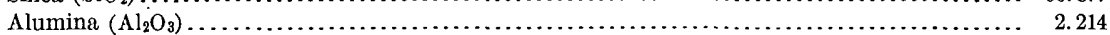

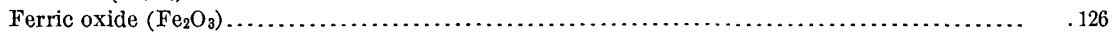

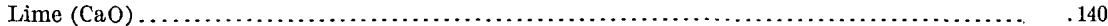

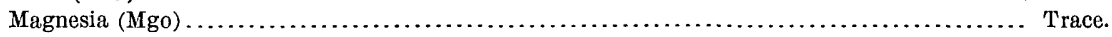

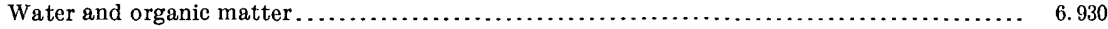

100.287

Various clays.-Near Dennis, on the farm of W. R. Davis, is a white clay interbedded in the Tuscaloosa sands. It contains minute particles of mica and differs from the white clays farther north in that it is less plastic. It is little more than a finely powdered silica, with just a sufficient amount of alumina to bond it. It burns to a cream color.

Clay of the same character occurs along the headwaters of Lick Creek. On M. C. T-till's land, in sec. 17, T. 6 S., R. 10 E., a white to cream-colored clay outcrops along the creek for 2 
miles. The clay is very plastic and free from sand and is similar in appearance when raw and also when burned to that on Mr. Paden's land.

The clays of the lower Tuscaloosa are not always so white and free from impurities as those above mentioned, but throughout the State highly plastic clays are frequently present where the Lafayette has been removed from the surface of the lower portion of the Tuscaloosa. The above-mentioned clays, though of exceptional purity and of high economic value, are as yet undeveloped. Farther south, in the lower Tuscaloosa arca in Itawamba County, there is less of the white clay, but a large amount of very plastic gray and often pink clays. Many of these clays are dark colored, containing more or less organic matter, bút when burned they become cream to pink-buff in color. Their high degree of plasticity renders them valuable for making stoneware.

Reedsville clay.-This clay outcrops along the headwaters of Reeds Creek about 6 miles south of Fulton, Itawamba County. There is more or less Lafayette and Tuscaloosa sand on the hills, which are often steep and wooded. The clay occurs near the base of the hills underneath $a$ seam of lignite about 18 inches thick. The following section shows the relation of the clay to the other strata:

Section on Reeds Creek 6 miles south of Fulton.

Ft. In.

5. Lafayette sands and pebbles..

4. Tuscaloosa sands, very coarse, alternating with thin strata of clay and containing small

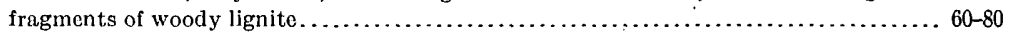

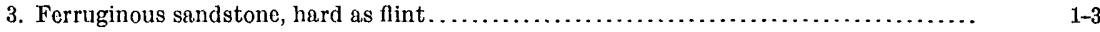

2. Black, pure lignite, containing small amount of iron pyrites....................... 18

1. Plastic gray clay, with more or less lignitic material through it.................. 10

Bottom of branch.

The lignite horizon is fairly constant throughout this locality. It gives rise to bold springs in many of the valleys. The clay was formerly used for making jug ware, but the plant has been discontinued. The ware burns to a color varying from rich cream to pale yellow.

Bull Mountain Creek and many of its small tributaries, in southeastern Itawamba County, have carried away much of the Lafayette and exposed in numerous places the underlying Tuscaloosa clays. There are three stoneware factories within a radius of 6 miles on the east side of Bull Mountain Creek.

Davidson clay.-This clay outcrops in the road near Jim Davidson's house, in sec. 29, T. 10 S., R. 10 E. It occurs in a horizontal stratum 4 feet thick, overlain by Lafayette sand. Numerous leaf impressions are reported from this clay. Between the clay pit and the house is a ledge of soft sandstone at a lower elevation than the clay stratum. Immediately below the sandstone is another stratum of siliceous clay but a few inches thick. The former clay is used at the Davidson pottery for making stoneware. It burns to a cream-buft color.

Sumerford clay.--On the farm of W. A. Sumerford, in the SW. $\frac{1}{4}$, sec. 11, T. 11 S., R. 10 E., the Lafayette has, in places, been entirely removed, leaving a bluish to pink clay at the surface. In the road at Mr. Sumerford's house the clay is exposed for 100 yards. It is horizontally bedded, but its thickness has not been ascertained. This clay is used by Mr. Sumerford for making stoneware, in which process it is necessary to mix the plastic clay which occurs but a foot or two below the surface with the more sandy surface clay. The color, when burned, is very similar to that of the Davidson clay. The analyses of the two clays are given below for comparison: 
Analyses of Davidson and Sumerford clays, Itawamba County.

[By W. F. Hand, State chemist.]

\begin{tabular}{|c|c|c|}
\hline$\therefore$ & $\begin{array}{l}\text { Davidson } \\
\text { clay. }\end{array}$ & $\begin{array}{l}\text { Sumerford } \\
\text { clay. }\end{array}$ \\
\hline Silica $\left(\mathrm{SiO}_{2}\right) \ldots \ldots \ldots \ldots$ & 59.12 & 62.58 \\
\hline Alumina $\left(\mathrm{Al}_{2} \mathrm{O}_{8}\right) \ldots$ & 27.44 & 27.58 \\
\hline Ferric oxide $\left(\mathrm{Fe}_{2} \mathrm{O}_{3}\right) \ldots \ldots \ldots \ldots \ldots$ & 4.39 & 1.57 \\
\hline Lime $(\mathrm{CaO}) \ldots \ldots \ldots \ldots \ldots \ldots \ldots \ldots$ & .34 & .40 \\
\hline Magnesia $(\mathrm{MgO}) \ldots \ldots \ldots \ldots \ldots \ldots$ & .28 & Trace. \\
\hline Sulphur trioxide $\left(\mathrm{SO}_{3}\right) \ldots \ldots \ldots$ & Trace. & Trace. \\
\hline Moisture..................... & .54 & .77 \\
\hline Loss on ignition.. & 7.40 & 6.77 \\
\hline
\end{tabular}

The analyses show the clays to be strikingly similar. The amount of silica and alumina in each is about equal. The Davidson clay contains more iron oxide than the Sumerford, though brick burned from the two clays at the same temperature show a slightly deeper pink for the Davidson clay.

One mile north of the Sumerford pottery E. P. Kennedy has a jug factory. Apparently the same stratum of clay is used at the two places. There is a greater thickness of Lafayette here than overlies the Sumerford clay, and the clay has a greater amount of iron oxide, as the analysis below will show. When burned the clay has a pink-buff color.

Analysis of clay from Kennedy factory, Itawamba County.

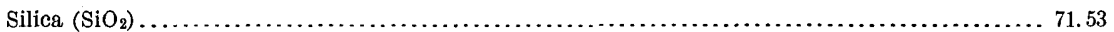

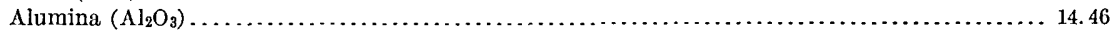

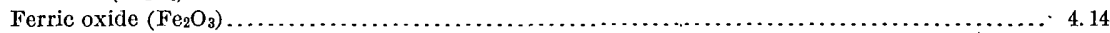

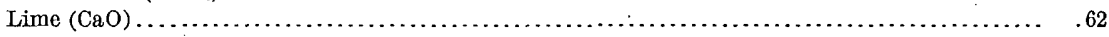

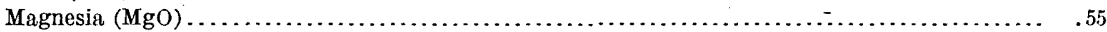

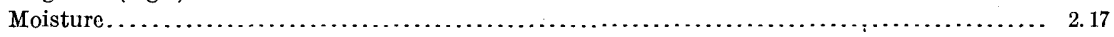

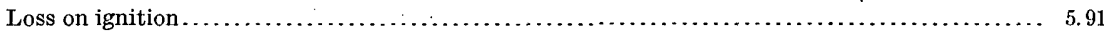

\section{PORTERS CREEK CLAYS (LOWER EOCENE).}

The clays of this formation underlie the well-known "Flatwoods" lying west of the Ripley area in northern Mississippi and west of the Selma chalk area south of Houston, Chickasaw County. The clays embrace the upper division of the series shown on the map as Midway. North of Pontotoc the clays are underlain by 20 feet or more of calcareous sands and this, in turn, by about the same thickness of Turritella limestone. South of Pontotor, however, the sands and limestone havc not been found if present and the entire Midway is composed of the Porters Creek clays.

There is a remarkable similarity in these clays throughout the State. When wet they are very stiff, of a gray or black color, but when dry they become a light gray to white.

The entire "Flatwoods" area throughout the State has always heen regarded as very poor agricultural land: The clayey soil is very poor in lime, phosphate, and other ingredients necessary to constitute fertility. The following analysis of the Porters Creek or Flatwoods elay soil was made by Dr. E. W. Hilgard: $a$

Analysis of Porters Creek clay soil.

Silica $\left(\mathrm{SiO}_{2}\right)$.

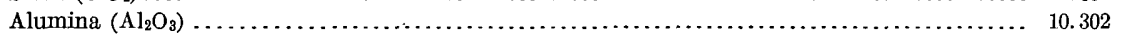

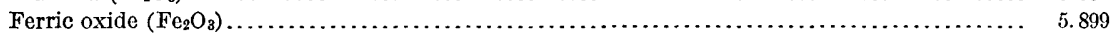

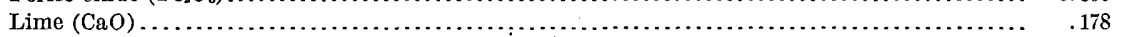

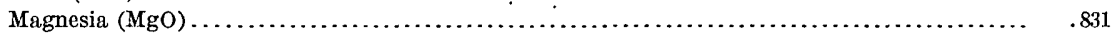

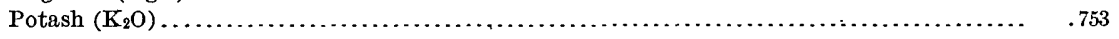




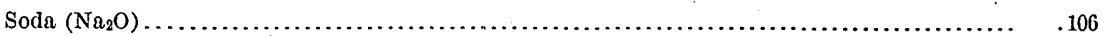

Brown oxide of Manganese................................................... 167

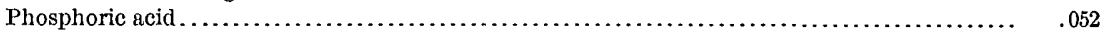

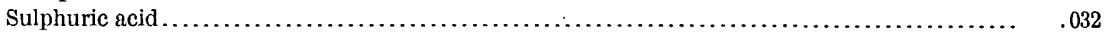

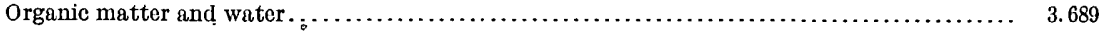

99.863

The Porters Creek clay comes to the surface along the Mobile, Jackson and Kansas City Railroad and on the hillsides and streams in Tippah County. At almost every place where it is seen it has a strikingly similar appearance, so that it can readily be distinguished from the Lafayette or Wilcox, lying farther to the west. It outcrops on the railroad one-half mile north of Walnut, Tippah County, at the water tank, and again one-half mile north of the tank. At each of these places it occurs in horizontal strata. It is very plastic, of a leaden-gray color, with a slight pink tinge. It is free from sand and does not effervesce with acid. Farther west it is reported to have a slight amount of calcareous matter through it. The same clay occurs in the hills $2 \frac{1}{2}$ to 3 miles southwest of Walnut, with a coarsegrained fossiliferous sandstone capping the tops of the hills.

The relation of the Porters Creek clay to the other strata in the vicinity of Walnut is given in the generalized section below:

\section{Generalized section near Walnut.}

5. Leaden-gray nonfossiliferous joint clay, as seen along railroad north of Walnut and in

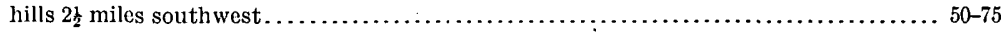

4. G reenish band of calcarcous sandstone, as seen at Chalybeate $\ldots \ldots \ldots \ldots \ldots \ldots \ldots \ldots . . \quad$. $8-26$

3. Yellowish calcareous sand, with slight amount of greensand present at Chalybeate and on Bobo place, east of Walnut........................................... $30-40$

2. Turritella limestone rock, as seen at Chalybeate and vicinity $\ldots \ldots \ldots \ldots \ldots \ldots \ldots \ldots \ldots .5-15$

1. "Owl Creek" marl, as seen at Chalybeate and farther south........................ 10

The "Owl Creek" marl bed belongs to the uppermost horizon of the Cretaceous. .All the strata above belong to the Tertiary. The same order of strata is present at Ripley.

As above stated, the Turritella limestone lying below and the fossiliferous sandstone above the Porters Creek clays have not been found in southern Mississippi. At Scooba, Kemper County, the heavy Flatwoods or Porters Creek clays are very common. The "Flatwoods" belt here is about 10 miles wide and the entire area is underlain by gray plastic clay. The following analysis of a sample of the clay from Scooba was made in the laboratory of the United States Geological Survey:

Analysis of Porters Creek clay from Scooba, Kemper County:

[By W: S. McNeil.]

Silica $\left(\mathrm{SiO}_{2}\right)$...

Alumina $\left(\mathrm{Al}_{2} \mathrm{O}_{3}\right) \ldots . . . . .$.

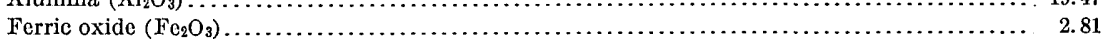

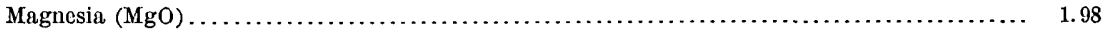

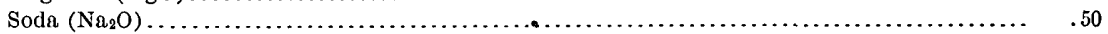

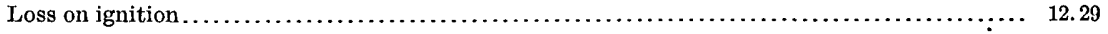

WILCOX. CLAYS (EOCENE).

98.97

The clays of the Wilcox formation comprise a large assortment, from the coarse sandy clays, well adapted for making lime-sand brick, to the white pottery clays as found at Holly Springs and Oxford. They occur more or less generally throughout the formation, but those which have so far been developed and used to any extent are found outcropping in a comparatively narrow belt that extends in a general north-south direction near the center of the Wilcox area. The outcrop of the clays is marked by a series of stoneware factories. This belt, from 3 to 10 miles wide, can be traced into Tennessee, and from the Tennessee line southward it passes through northwestern Benton, eastern Marshall, central Lafayette, western Calhoun, central Webster, eastern Choctaw, and central Winston counties. Farther south there has been no detailed work to determine whether or not the clays are present. 
There is a great similarity in the clays from the Tennessee line to Calhoun County. Fortyfive samples were collected from Benton, Marshall, and Lafayette counties. When made into small bricks and burned to the same temperature they show a striking similarity. In color they range from almost pure white to a light chocolate, with all of the intermediate shades.

The clays of this formation may be divided into two distinct groups-stratified and unstratified clays.

$$
\text { STRATIFIED CLAYS. }
$$

The class of stratified clays includes the more arenaceous clays which occur in horizontal strata interbedded with the coarse, laminated sands of the Wilcox. . In places the clays are remarkably free from impurities and could be used for various economic purposes. In some places they are being made into common stoneware, such as jugs, crockery, and churns.

The greater part of the stratified clays contain too much free sand for stoneware and pottery, but could be used advantageously for making a high grade of white to buff-colored pressed brick, fire brick, lime-sand brick and pavers, terra cotta, and tiling.

\section{UNSTRATIFIED CLAYS.}

The high-class white pottery clays found particularly in the northern counties occur in large lens-shaped bodies. They are comparatively free from sand and other impurities. The potteries of Holly Springs obtain their clay from these unstratified bodies. Fossil leaf impressions have been found throughout the clays.

The composition of these clays, as shown by the analyses below, is such that they can be used for making low-grade pottery and in some instances a finer grade of ware. They could also be used for making gas retorts, crucibles, and fire brick.

\section{NOTES ON WILCOX CLAYS.}

Brown clay.--In sec. 25, T. 1, R. 2 E., near Laird, Benton County, clay occurs in laminated sands of the Wilcox, from which the Lafayette has been removed. It is plastic, free from sand, and burns to a cream-white color. Numerous other outcrops occur in the gullies near by. An analysis of this clay is given below:

\section{Analysis of Brown clay, Benton County.}

[By W. F. Hand, State chemist.]

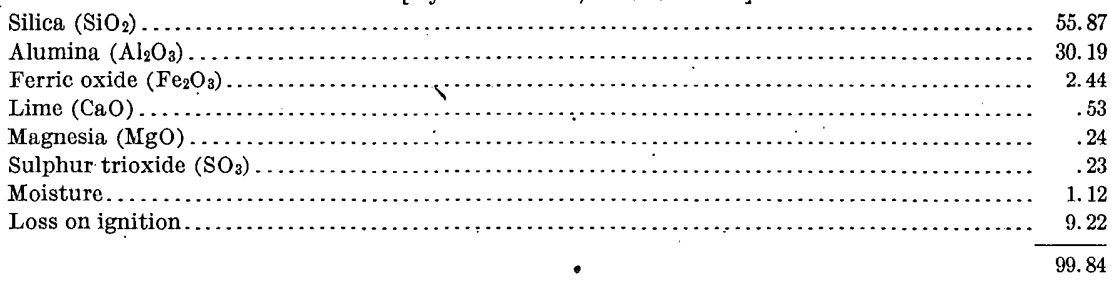

Maclin clay.-In seg. 28, T. 1 S., R. 2 E., Benton County, on J. Maclin's land, clay occurs in a deeply washed gully at the top of Wilcox sands. It is overlain by the Lafayette sands. The raw clay has a slightly bluish color, but burns to a cream-white. It is high in alumina and therefore very plastic. In almost every large gully where the overlying Lafayette has been removed the white Wilcox clays are present. The thickness of the deposits is undetermined. An analysis of the Maclin clay is given below: 
Analysis of Maclin clay, Benton County.

[By W. F. Hand, State chemist.]

Silica $\left(\mathrm{SiO}_{2}\right)$

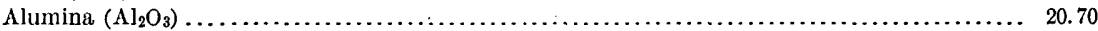

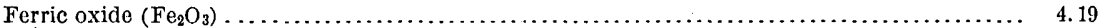

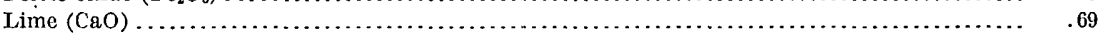

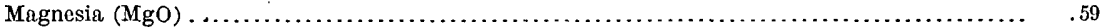

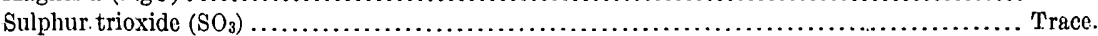

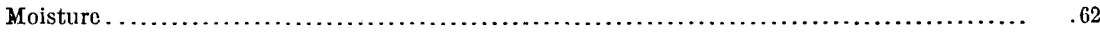

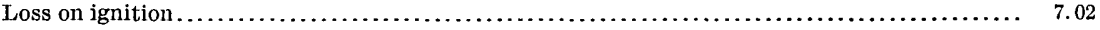

98.67

Parham clay.-A very fat white clay occurs in the NW. 1 sec. 36, T. 1 S., R. 1 E., Benton County. It is free from sand and burns to a rich cream color. It occurs in a large lens-shaped body, 4 feet thick, and is uncovered for 100 yeards along a branch. When dry the clay has a tendency to break up into large rectangular blocks. Fossil leaf impressions are abundant. This clay has been used by the Grand Junction Pottery Company and found to be excellent for making common stoneware. Below is an analysis of the Parham clay:

\section{Analysis of Parham clay, Benton County.}

[By W. F. Hand, State chemist.]

Silica $\left(\mathrm{SiO}_{2}\right)$

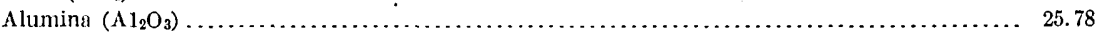

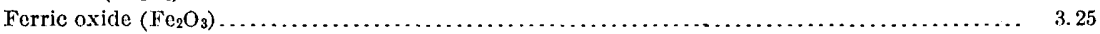

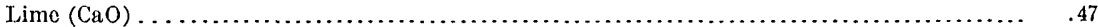

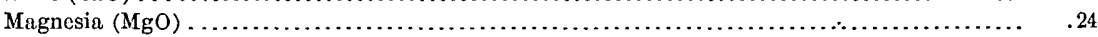

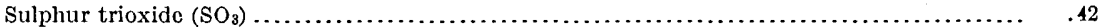

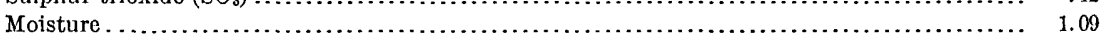

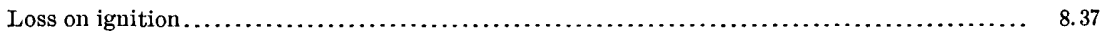

98.64

Umbarger clay.-In sec. 2,T. 2 S., R. 2 E., a yellow, lean, sandy clay occurs in the stratified Wilcox sands. The clay here is entirely below the Lafayette and is made up of thin laminæ of clays intermingled with more or less fine sand. It burns to a rich buff color. As in the other places mentioned above the clay is present in a large number of gullies where the surface soil and Lafayette have been washed away. An analysis of this clay is given below:

\section{Analysis of Umbarger clay, Benton County.}

[By W. F. Hand, State chemist.]

Silica $\left(\mathrm{SiO}_{2}\right)$

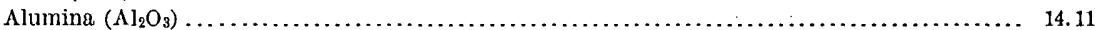

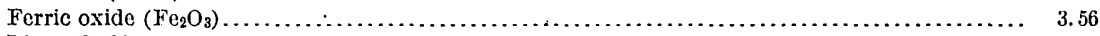

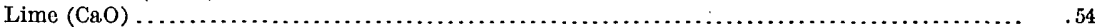

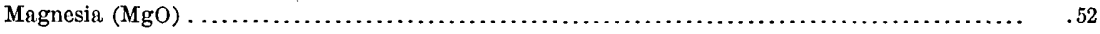

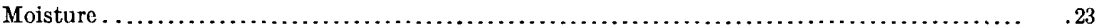

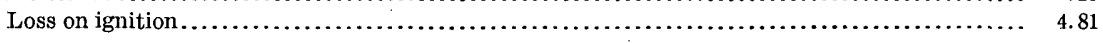

Boughton clay.-A gray clay with pink streaks through it occurs in the Wilcox strata in the NW. $\frac{1}{4}$ sec. 34, T. 1 S., R. 2 E., Benton County. It is free from sand and highly plastic. The following is an analysis of this clay:

Analysis of Boughton clay, Benton County.

[By W. F. Hand, State chemist.]

Silica $\left(\mathrm{SiO}_{2}\right)$.

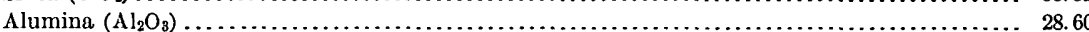

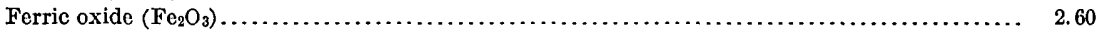

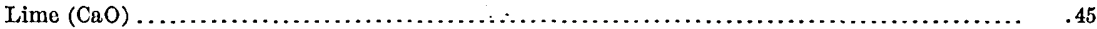

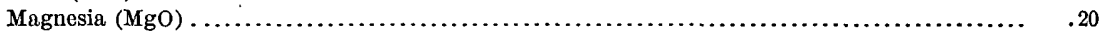

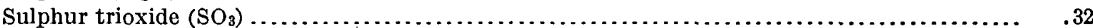

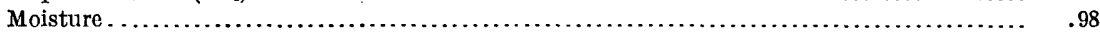

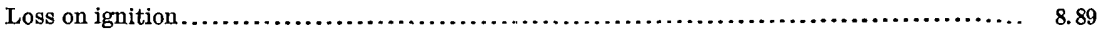


Poorhiouse clay.-Clay occurs in a large branch on the public road in front of the poorhouse in sec. 26, T. 3 S., R. 3 W., Marshall County. The Lafayette is present on the hillside and has washed down to and overlies the clay bed. The clay occurs in a large lens, with a thickness of 10 feet exposed. The entire thickness has not been determined, as it is undeveloped. This clay has been tested by A. Herr, manager of the Holly Springs Stoneware and Fire-Brick Company, and he found it to be an excellent clay for making stoneware. It is of a leaden-gray color when damp and burns to a rich cream or white. The following is an analysis of the Poorhouse clay:

\section{Analysis of Poorhouse clay, Marshall County.}

[By W. F. Hand, Sta te chemist.]

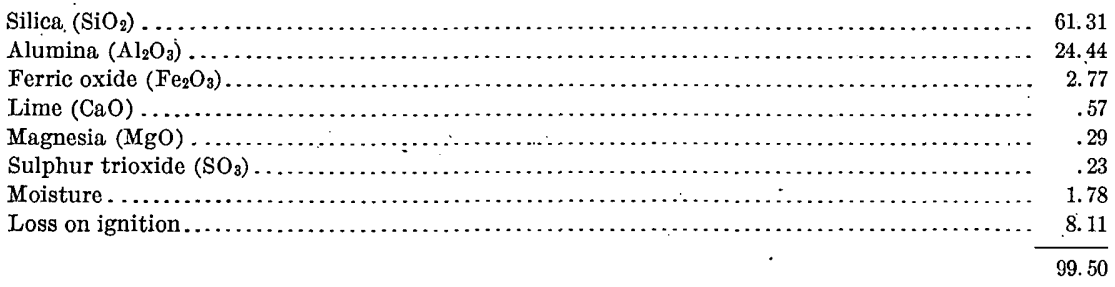

McDowell clay.-In the Illinois Central Railroad cut, one-half mile south of Mahon station, in sec. 25 , T. 3 S., R. 3 W., occurs a highly siliceous, lean, nonplastic clay containing small particles of mica, several feet below the base of the Lafayette. This clay burns to a lightcream color.

The following section shows the relation of the clay to the stratified Wilcox and the overlying Lafayette and surface loam:

Section in Illinois Central Railroad cut one-half mile south of Mahon station.

Yellow (Columbia) loess loam Feet.

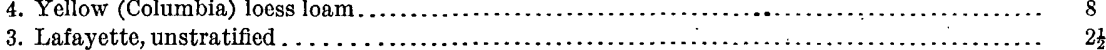

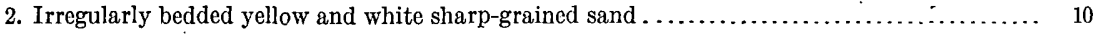

1. Red coarse-grained sand with thin bands of ferruginous sandstone. This bed is more irregularly bedded than the one above and the sand grains are much larger. The clay occurs in this bed of coarse sand in a long lenticular mass, which grades into a clayey sand. Thickness of the clay, 10 feet

The following is an analysis of the McDowell clay:

Analysis of McDowell clay, Marshall County.

[By W. F. Hand, State chemist.]

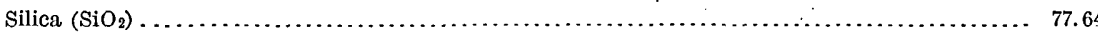

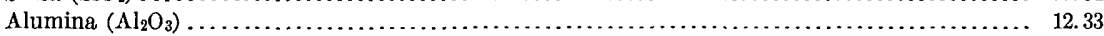

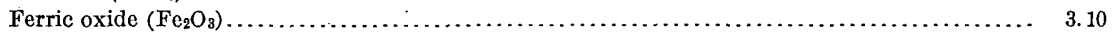

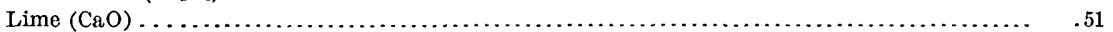

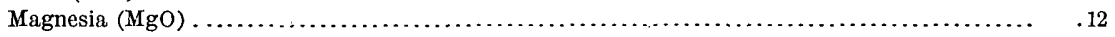

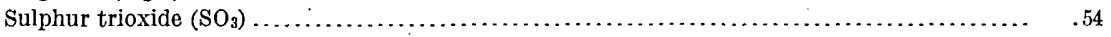

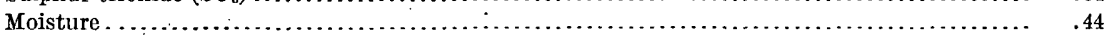

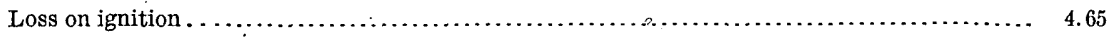

99.33

A few hundred yards south of the above-mentioned clay a more plastic clay outcrops on each side of the railroad track. It has a bluish tinge when fresh and damp and burns to a very light cream color, almost white. No analysis of this clay bas been made.

Fant clay.-Highly colored white, pink, and gray clays, many of them free from sand, are present in numerous gullies and along the streams in sec. 9, T. $3 \mathrm{~S} .$, R. $3 \mathrm{~W}$. , on the farm of Ernest Fant. They occur in lenticular masses embedded in the sand. In some places the Lafayette rests directly on the clay, in others the clay is entirely in the highly stratified variegated sands. The following is an analysis of the Fant clay: 
Analysis of Fant clay, Marshall County.

[By W. F. Fland, State chemist.]

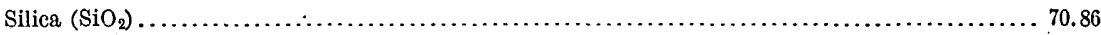

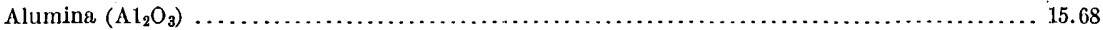

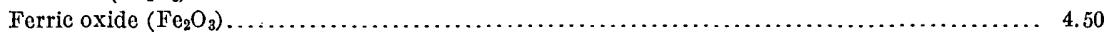

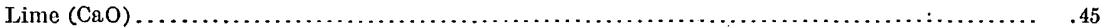

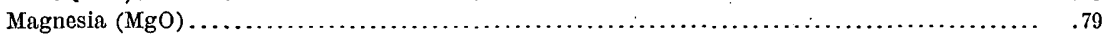

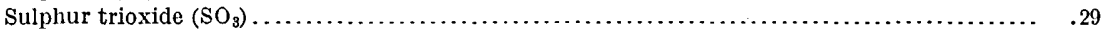

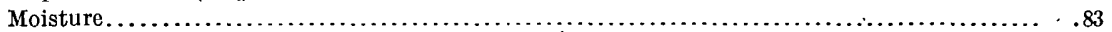

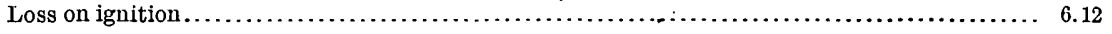

99.52

Terr clay.-On Home Terr's land, in sec. 35, T. 2. S, R. 3 W., the stratified character of the Wilcox sands and clays is well shown in the section along the creek near the old water mill. A small side stream entering the creek at the mill has cut through the Lafayette and into the alternating beds of sands and clays beneath. At the base of the section is a yellow plastic clay from which a sample was taken. When made into a brick and burned it becomes of a rich buff color. The following section gives the relation of the different strata:

Section on Terr place, in sec. 35, T. 2 S., R. $3 \mathrm{~W}$.

7. Lafayette... Inches.

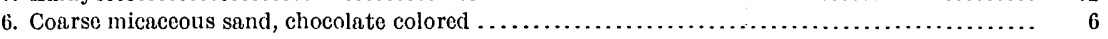

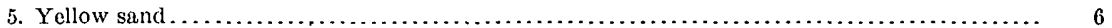

4. Yellow sand ạlternating with white clay one-fourth to 1 inch thick $\ldots \ldots \ldots \ldots \ldots \ldots \ldots \ldots \ldots \ldots \ldots \ldots$

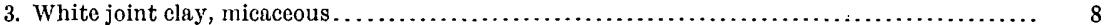

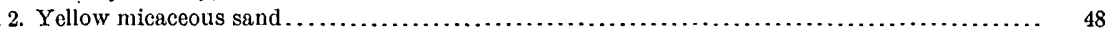

1. Yellow clay from which sample was taken; bottom of branch........................ 24

The following is the analysis of the Terr clay:

Analysis of Terr clay, Marshall County.

[By W. F. Hand, State chemist.]

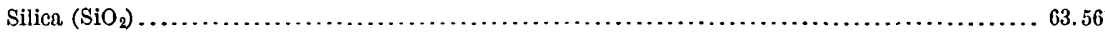

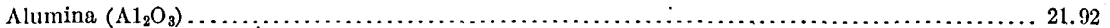

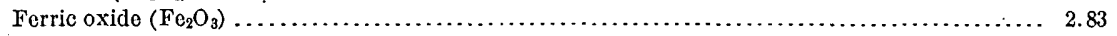

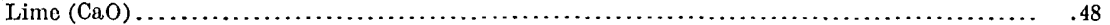

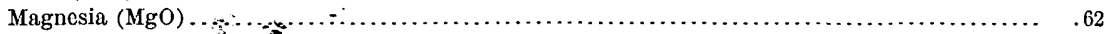

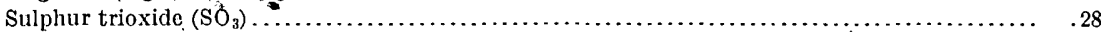

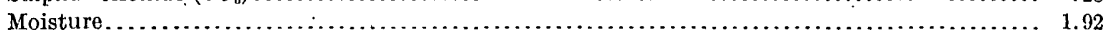

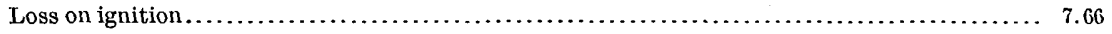

99.27

Ballard clay.-In the old field surrounding the negro schoolhouse in sec. 30,T. 2 S., R. 2 W., are numerous deep gullies. In many of these plastic, workable clays are exposed.

At the bold spring near the schoolhouse is a small bluff showing 20 feet of coarse, orangecolored sand, with small streaks and lenses of clay throughout. At the base of the bluff is a large outcrop of very plastic white to pinkish clay which has given rise to the spring. The water filters down through the sand until it reaches the clay. On the opposite side of the schoolhouse from the spring is an outcrop of stratified clay in a gully. When exposed to the sun and air this clay, known as the Ballard clay, cracks into roughly rectangular blocks, as does the Parham clay. Like the Parham clay also it contains numerous fossil leaf im: pressions. The clay is white, contains but little sand, and burns almost white. An analysis of this clay is given below: 
Analysis of Ballard clay, Marshall County.

[By W. F. Hand, State chemist.]

Silica $\left(\mathrm{SiO}_{2}\right)$

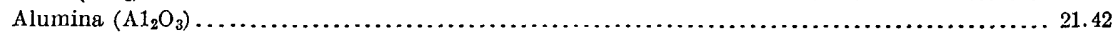

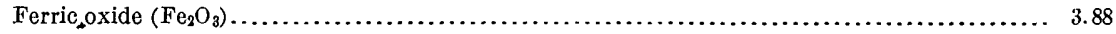

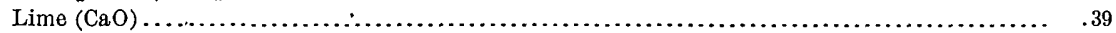

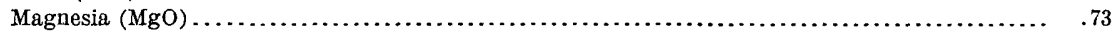

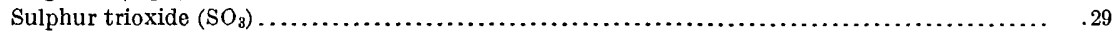

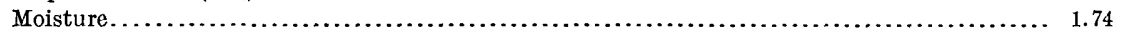

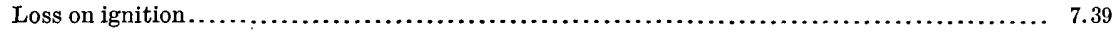

99.79

Red Bank clay.- One of the best localities for studying the lenticular character of the Wilcox is in the high divide between the waters of Chewalla Creek on the north and Red Bank Creek on the south, in the vicinity of Red Bank station, in sec. 16, T. 3 S., R. 4 W. About one-half mile south of the station is a large abandoned field from which the Lafayette has been mostly eroded. In places the gullies are washed out 20 feet deep and the whole field is fantastically carved into miniature landscapes. The Wilcox here contains numerous lenses of white, gray, and pink clays, many of which are highly plastic and free from sand. In places the gullies are deep enough to show the full thickness of the clay deposits-not more than 3 to 4 feet on an average. A sample of clay was taken from a large lenticular body on the roadside one-fourth mile south of the church. It burned to' a buff color and is flecked with small brown to reddish spots. Below is an analysis of the Red Bank clay.

Analysis of Red Bank clay, Marshall County.

[By W. F. Hand, State chemist.]

Silica $\left(\mathrm{SiO}_{2}\right)$. 65.88

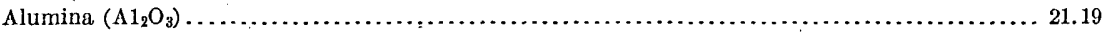

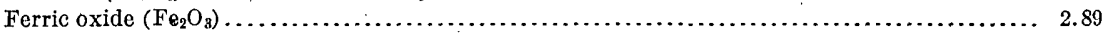

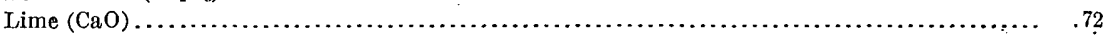

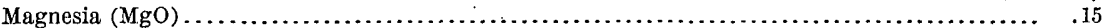

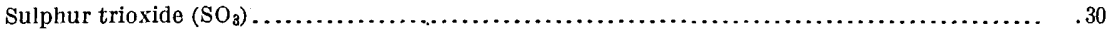

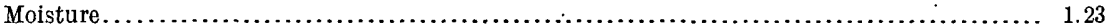

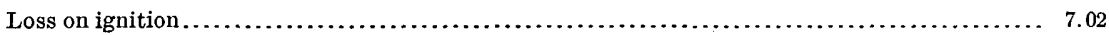

$\overline{99.38}$

Hern clay.-This deposit occurs on the roadside about $3 \frac{1}{2}$ miles north-of Holly Springs and about one-half mile north of the old pit from which the Holly Springs Stoneware and Fire-Brick Company formerly obtained clay for making stoneware. The Hern clay occurs in stratified layers with sand partings. It has a bluish tint, is very plastic, and burns to a buff color very similar to that of the Red Bank clay. Its relation to the Lafayette is shown in the section below.

\section{Section $3 \frac{1}{2}$ miles north of Holly Springs.}

Feet.

4. Lafayette sands with ferruginous sandstone at base. $10-12$

3. Stratified plastic clay of a bluish tint, in places containing a small amount of sand .......... 3

2. Gray laminated clay 1 to 4 inches thick, alternating with layers of gray sand of about equal

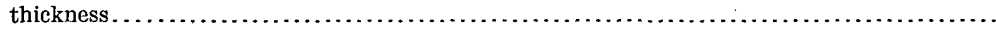

1. Yellowish laminated sand and clay containing nodules of iron oxide....

This clay has been analyzed with the following results:

Analysis of Hern clay, Marshall County.

[By W. F. Hand, State chemist.]

Silica $\left(\mathrm{SiO}_{2}\right)$

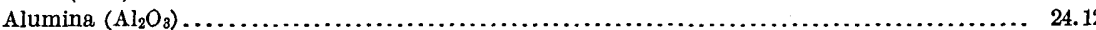

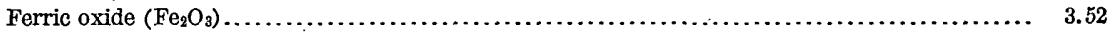

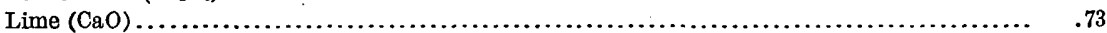

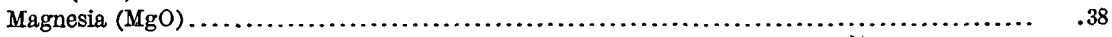

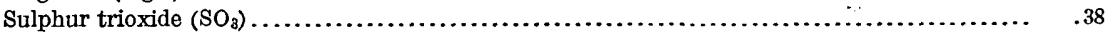

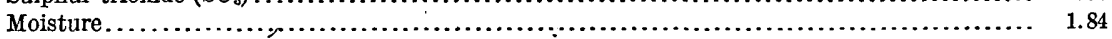

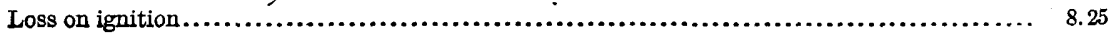


Holly Springs clay.-The clay deposit at Holly Springs is in a large branch on the west side of the Illinois Central Railroad, about one-fourth mile north of the depot. The clay is a bluish gray with yellow horizontal streaks through it, giving it a laminated appearance. A small amount of gray sand is embedded in the clay. The deposit is not continuous for more than 25 feet and is $4 \frac{1}{2}$ feet thick. It is overlain by 10 feet of deep Indian-red Lafayette. An interesting feature of this deposit is the large number of small lenses of highly plastic clay in the sand around the large deposit. Some of these small bodies are 2 feet long and from 1 to 2 inches thick. They are not very far distant from the larger mass and are entirely wanting in the Lafayette. The following is an analysis of this clay:

Analysis of Holly Springs clay, Marshall County.

[By W. F. Hand, State chemist.]

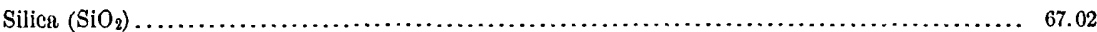

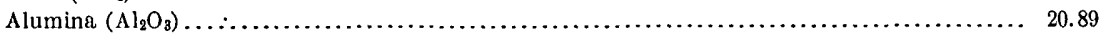

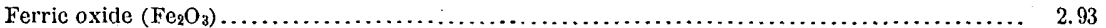

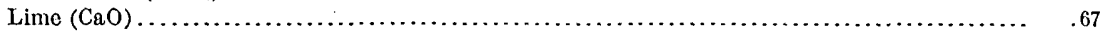

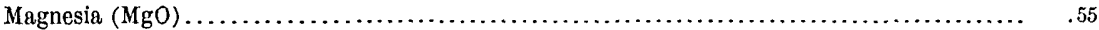

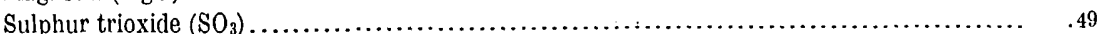

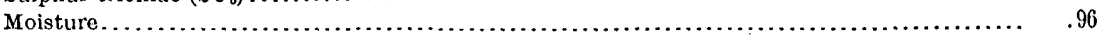

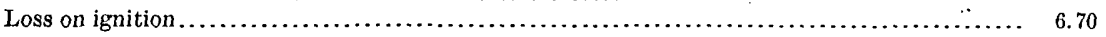

100.21

Dunlap clay. - A clay deposit occurs on Joe Dunlap's land in the cut where the Holly Springs and Pontotoc road crosses the Frisco Railroad. The clay is horizontally bedded and is exposed for a distance of 350 feet along the cut, with a thickness of 2 feet showing above the surface. It is a tough, white, siliceous clay, flecked with small particles of mica and burns to a cream-white. It is overlain by 6 to 7 feet of micaceous clayey sand. The top of the hill is covered with 6 to 7 feet of yellow loam. The following analysis has been made of the Dunlap clay:

Analysis of Dunlap clay, Marshall County.

[By W. F. Frand, State Chemist.]

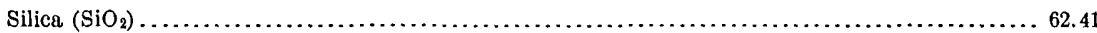

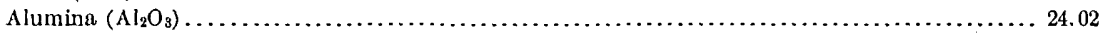

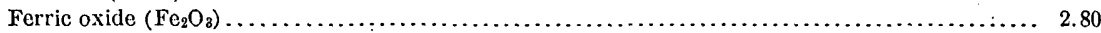

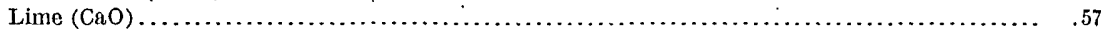

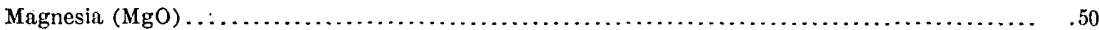

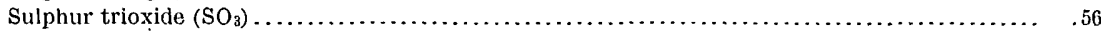

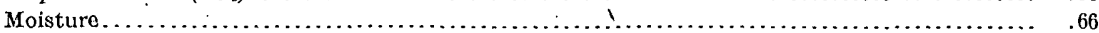

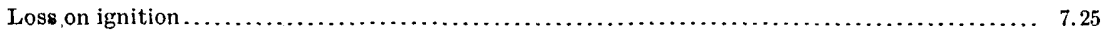

$\overline{98.77}$

Holly Springs stoneware clay.-One and one-half miles east of the Holly Springs depot is a small area comprising 20 or 30 acres from which the Holly Springs Stoneware Company gets the clay for making its ware. The clay occurs in large lenticular masses with a maximum length of 80 feet. Perhaps 25 yards from the point where one of these lenses cuts out, another large lens, or "mountain," as the clay digger calls it, will begin. The greatest thickness of the clay so far penetrated is 18 feet, and the bottom was not then reached. One pit is used until it gets too deep to throw the clay out with a shovel or until a rain fills it with water, and it is then abandoned and another opened. Small deposits of pure sand, from 1 inch to 1 foot thick and 2 to 3 feet long, often occur in the center of the clay lenses. The digger reports that numerous leaf impressions are found at a depth of 10 to 12 feet. Clay coming from a depth of 10 feet works better thian that near the surface. This clay is very plastic, free from sand, and has to be mixed with a more sandy clay before it is made into stoneware. It burns to a cream color under high heat. The following is an analysis of this clay: 
Analysis of Holly Springs stoneware clay, Marshall County.

[By W. F. Hand, State chemist.]

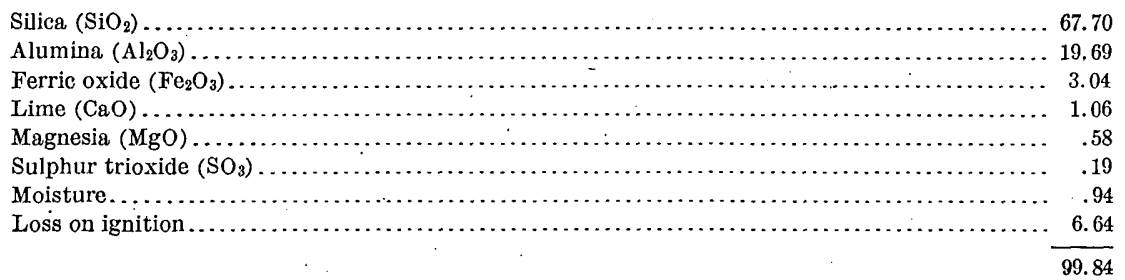

Allison stoneware clay.--The clay used by the Allison pottery comes from a pit along the same branch as the Holly Springs stoneware-clay pit. The Allison clay differs from the other clay in being stratified instead of occurring in lenses. At the top of the pit are 4 to 5 feet of Lafayette, below which are 10 feet of clay. The upper half of the clay is more arenaceous than the lower and has a pinkish color. The lower half is a white plastic clay which is used for making stoneware. . Immediately below the white clay is a thin band of lignite, and this in turn is underlain by 4 to 5 feet of variegated sands. A glance at the sands. shows white, black, red, orange, yellow, and blue colors. The following analysis shows the composition of the Allison clay:

\section{Analysis of Allison stoneware clay, Marshall County.}

[By W. F. Fand, State chemist.]

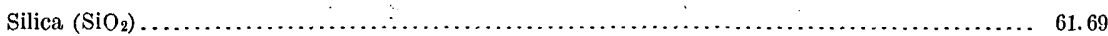

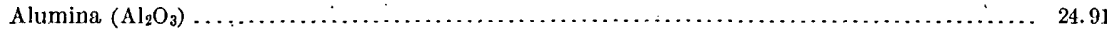

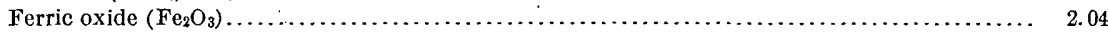

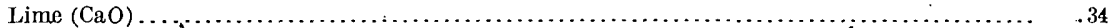

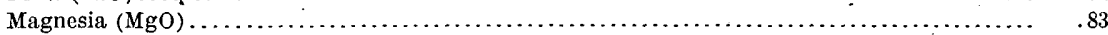

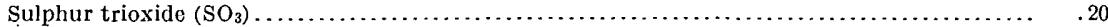

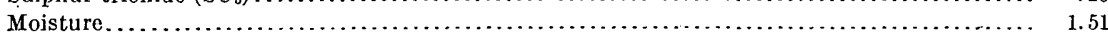

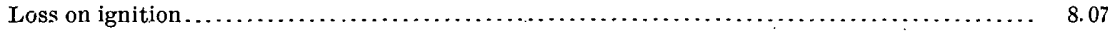

99.59

Frisco fire clay.-About 100 yards east of the Frisco depot at Holly Springs is a deposit of white sandy clay which is made into fire brick and used in lining the kilns of the Holly Springs Stoneware Company. The bricks stand the highest degree of heat required in burning the ware without going to pieces. In appearance the clay is little more than a mass of slightly bonded sand which occurs at the surface in large bodies and is distinct in color from the loose variegated sands in the vicinity. The following is an analysis of this clay:

\section{Analysis of Frisco fire clay, Marshall County.}

[By W. F. Hand, State chemist.]

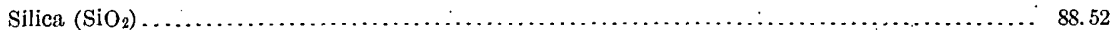

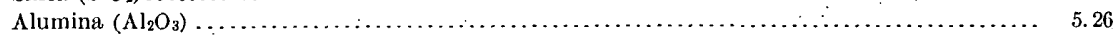

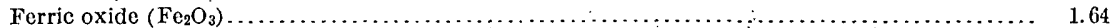

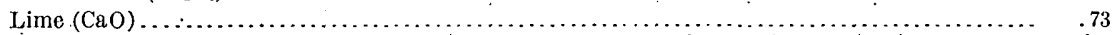

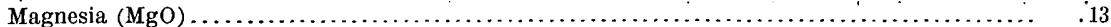

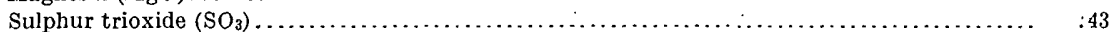

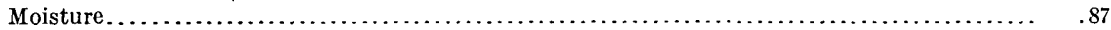

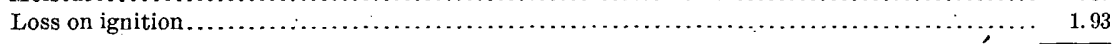

99.51.

A clay very similar to the one above mentioned, as is shown by the analysis given below, occurs just south of the Frisco depot: 
Analysis of Frisco fire clay No. 2, Marshall County.

[By W. F. Hand, State chemist.]

Silica $\left(\mathrm{SiO}_{2}\right)$ 84.40

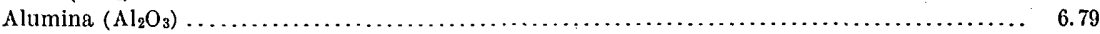

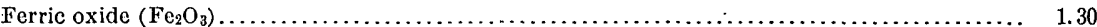

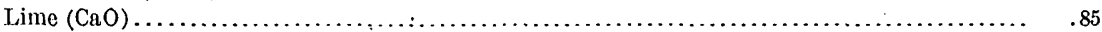

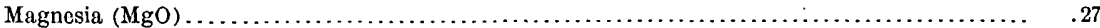

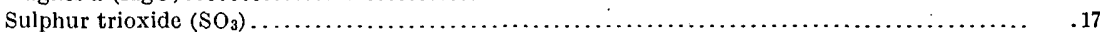

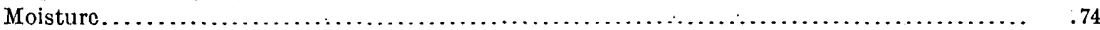

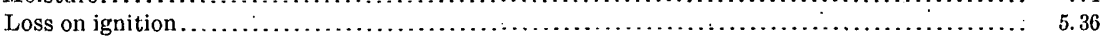

99.88

Whitelock clay.-The Whitelock clay outcrops at the spring where the Illinois Central Railroad crosses the public road, 2 miles south of Holly Springs. It is a white plastic clay flecked with mica, and occurs in stratified sands 40 feet below the base of the Lafayette. It burns to a cream color. An analysis of this clay is given below:

\section{Analysis of Whitelock, clay, Marshall County.}

[By W. F. Hand, State chemist.]

Silica $\left(\mathrm{SiO}_{2}\right)$

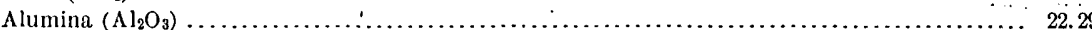

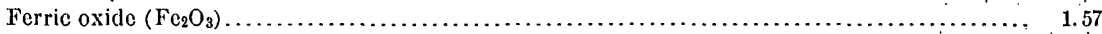

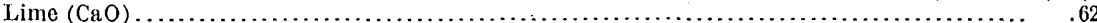

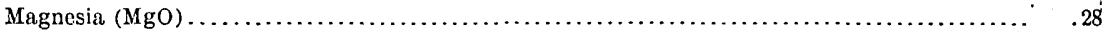

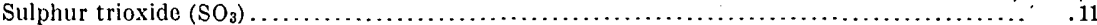

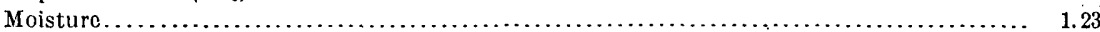

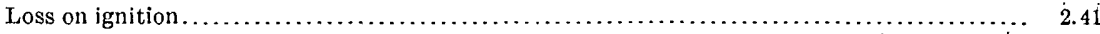

95.17

Wyley clay.-A very white nonplastic clay occurs in stratified layers near the house of Sid. Wyley, in sec. 16, T. 8 S., R. 4 W., Lafayette County. The following section was taken from the gully in which the clay outcrops:

\section{Section on Wyley place, in sec. 16, T. 8 S., R. 4 W.}

5. Yellow loam and Lafayette at surface.

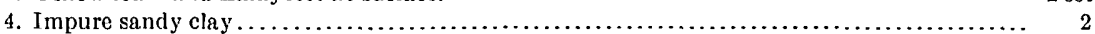

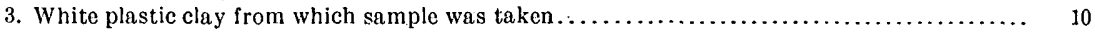

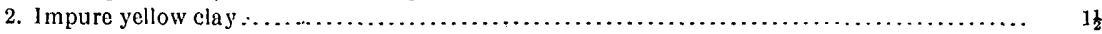

1. Whitish-gray sand to bottom of gully $\ldots \ldots \ldots \ldots \ldots \ldots \ldots \ldots \ldots \ldots \ldots \ldots \ldots \ldots \ldots \ldots \ldots \ldots, 2$

At the base of the yellow clay is a thin band of ferruginous sandstone and numerous concretions of iron clay stones. The following analysis has been made of this clay:

Analysis of Wyley clay, Lafayetle County.

[By W. F. Hand, State chemist.]

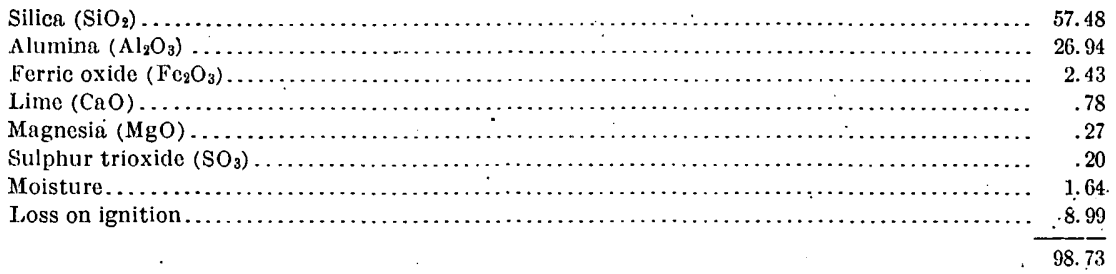

Callicoatt clay.-An outcrop of clay occurs near C. C. Callicontt's house, in sec. 16, T. 9 S., K. $3 \mathrm{~W}$. This clay is slightly yellowish, free from sand, and burns to a rich cream color. There is an old Indian pottery near by, with numerous pieces of pottery which were made from this clay bank. The following is an analysis of the Callicoatt clay: 
Analysis of Callicoatt clay, Lafayette County.

[By W. F. Hand, State chemist.]

Silica $\left(\mathrm{SiO}_{2}\right)$

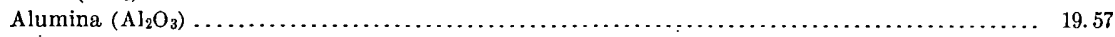

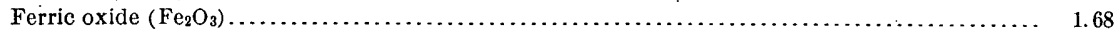

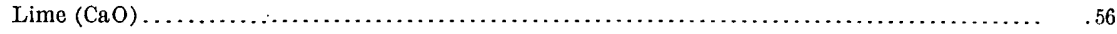

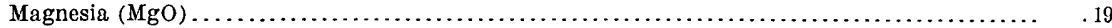

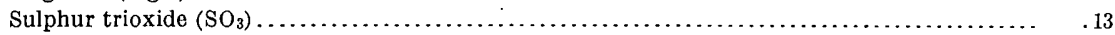

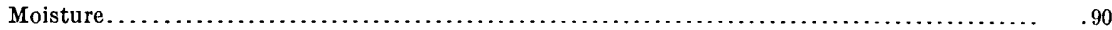

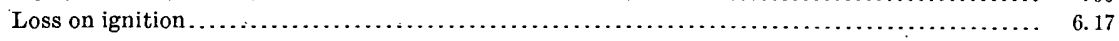

Moss clay.-This clay outcrops in a deep gully on the public road just in front of a negro cabin on Robert Moss's land: The Lafayette rests directly on the clay, which occurs in a lenticular mass in the variegated sands of the Wilcox formation. The clay is free from grit, very fat, and has a pinkish tinge. The thickness of the deposit is at least 10 feet. Below is an analysis of the Moss clay:

\section{Analysis of Moss clay, Lafayette County.}

- [By W. F. Hand, State chemist.]

Silica $\left(\mathrm{SiO}_{2}\right)$.

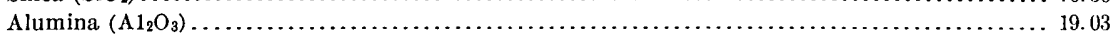

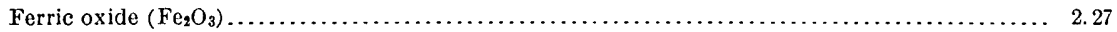

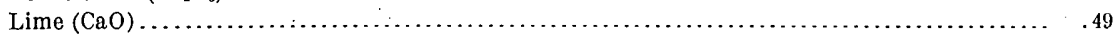

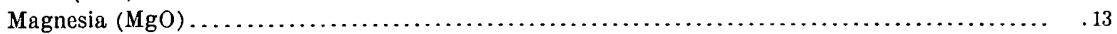

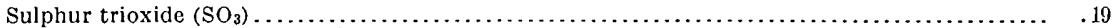

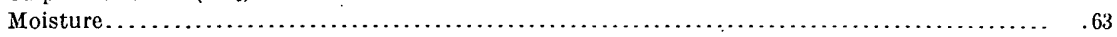

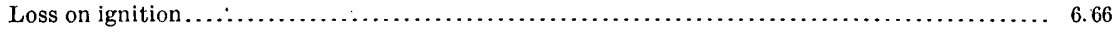

99.96

Miller clay.-In the vicinity of George Miller's house, in sec. 8, T. 8 S., R. 3 W., are large bodies of very lean, nonplastic soapstone or clay which often cover an acre or more. The clay is almost snow white and, where the Lafayette has been removed, can be seen for a long distance before reaching the outcrop. These deposits occur in horizontal laminæ one-fourth inch to 2 inches thick. More or less mica is present throughout, with a large amount of highly siliceous material. This clay has been analyzed with the following results:

\section{Analysis of Miller clay, Lafayette County.}

[By W. F. Hand, State chemist.]

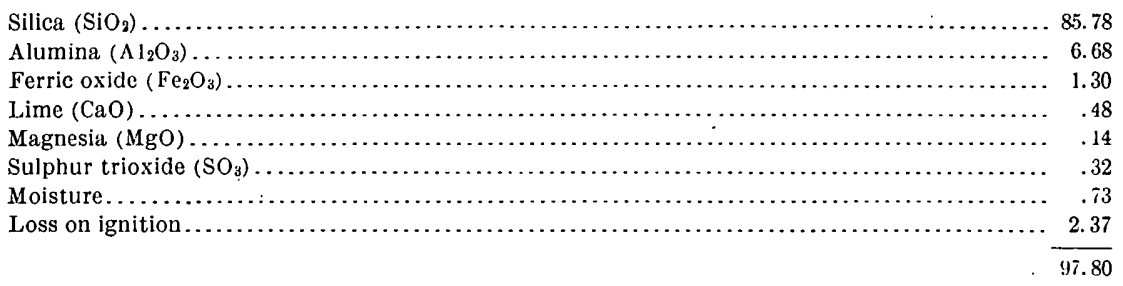

Oxford clay.-A sample of clay was obtained from the deep gully near the colored-school building in the town of Oxford. On all sides of the town the variegated coarse sands of the Wilcox appear in the gullies and along the roads and railroad. The sand is highly crossbedded. The sample of clay was taken in this cross-bedded sand at the base of the Lafayette. The clay is plastic, free from grit, and burns to a white color. The following is an analysis of this clay: 
Analysis of Oxford clay, Lafayette county.

[By W. F. Hand, State chemist.]

Silica $\left(\mathrm{SiO}_{2}\right)$

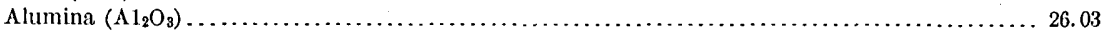

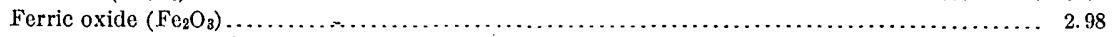

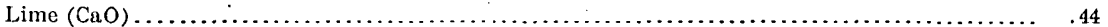

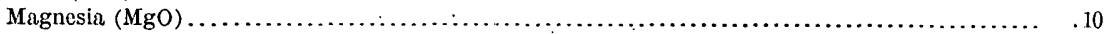

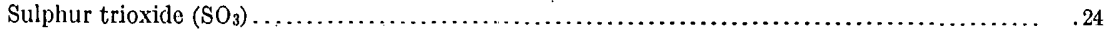

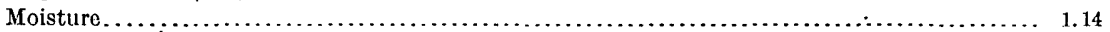

Loss on ignition $\ldots \ldots \ldots \ldots \ldots \ldots \ldots \ldots \ldots \ldots \ldots \ldots \ldots \ldots \ldots \ldots \ldots \ldots \ldots \ldots \ldots \ldots \ldots \ldots \ldots \ldots \ldots, 11$

$\overline{97.83}$

Russell clay.-A stratified plastic gray clay outcrops in a deep gully on Walsh Rंussell's land, in Lafayette County, and has been analyzed as follows:

Analysis of Russell clay, Lafayette County.

Silica $\left(\mathrm{SiO}_{2}\right)$.

[By W. F. Hand, State chemist.]

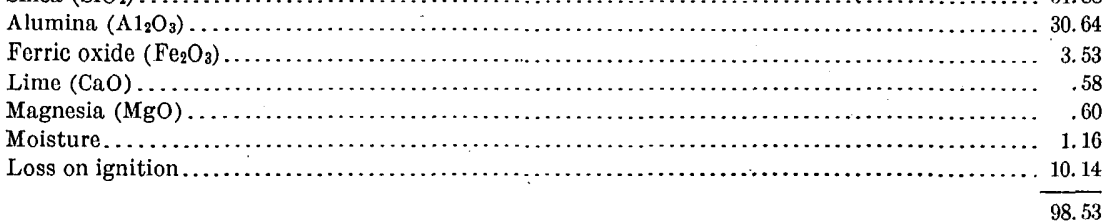

Grenada clay No. 1.-At the wagon bridge across Yalobusha River at Grenada the darkblue lignitic clay of the upper Wilcox formation outcrops in the river bank, where there is an exposure of this clay 20 feet thick. It is overlain by more sandy clays, which alternate with strata of micaceous sand to the top of the high hill west of Grenada. There is more or less fine siliceous sand and mica in the dark clay at the bridge. When burned the clay. becomes a pale rusty red, owing to the presence of iron oxide. The following is an analysis of this clay:

Analysis of Grenada clay No. 1, Grenada County.

[By W. F. Hand, State chemist.]

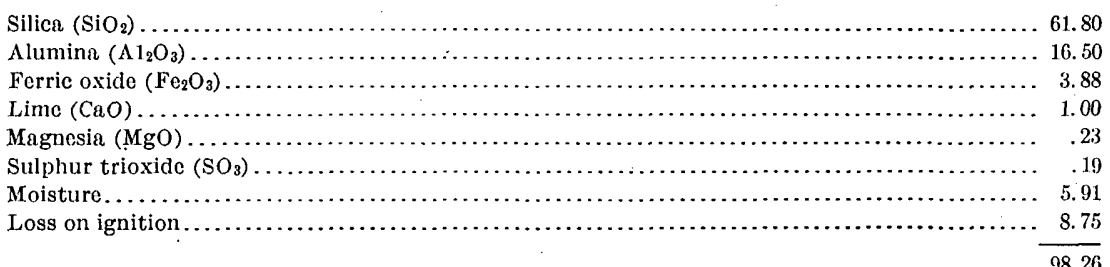

Grenada clay No. 2.-At the foot of the high range of hills 1 mile east of Grenada, on the public road, is a very siliceous clay belonging to the Wilcox formation. This has been analyzed as follows:

\section{Analysis of Grenada clay No. 2, Grenada County.}

[By W. F. Hand, State chemist.]

Silica $\left(\mathrm{SiO}_{2}\right)$

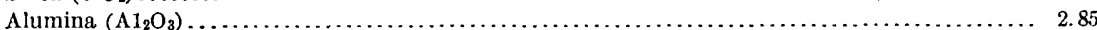

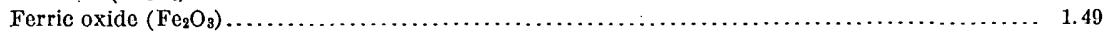

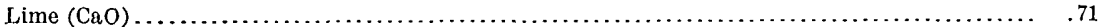

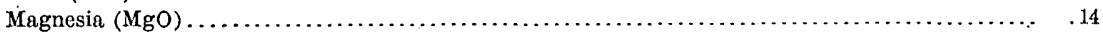

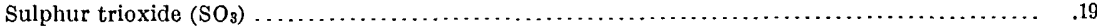

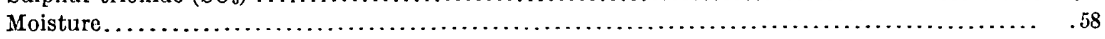

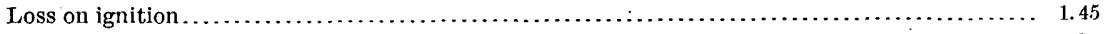


Winston County stoneware clay.-On the old Eiland place, in sec. 16, T. 15 N., R. 13 W., Wirston County, in a deep gully along the public road, is an outcrop of clay, which is being us: $\mathrm{d}$. by the Webster and Joplin stoneware potteries for making common stoneware. The clay is pink with streaks of white, resembling castile soap. Like the Parham clay, when air dried, it breaks up into more or less rectangular blocks. It occurs in a lenticular mass $2 \frac{1}{2}$ feet thick in the bed of clayey, indurated sand containing mica. The clay burns to a rich buff color. The following analysis has been made of this clay:

\section{Analysis of Winston County stoneware clay.}

[By W. F. Hand, State chemist.]

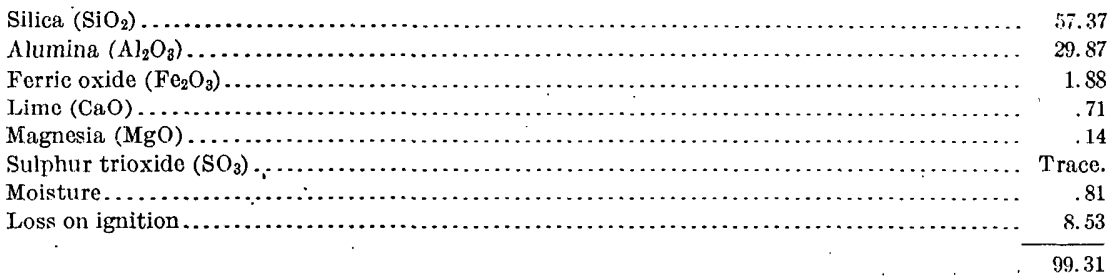

Webster County stoneware clay.-At Cumberland, Webster County, is a small stoneware factory, which secures its clay from a pit on the side of the public road on land belonging to B. F. Sanders, in sec. 22, T. 20 N., R. 11 W. The clay has a chocolate color, due to the carbonaceous matter, and does not require the admixture of other clays for making stoneware. It burns to almost a snow white. It occurs in stratified planes overlain by a less pure sandy clay. The following is an analysis of this clay:

Analysis of Webster County stoneware clay.

[By W. F. Hand, State chemist.]

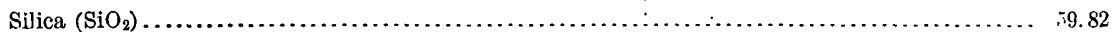

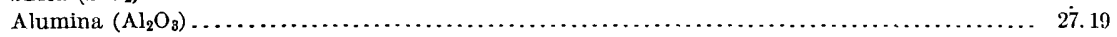

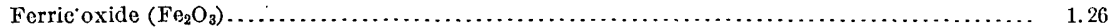

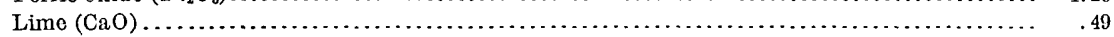

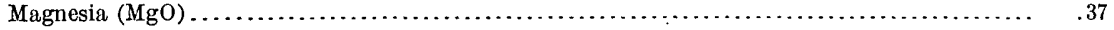

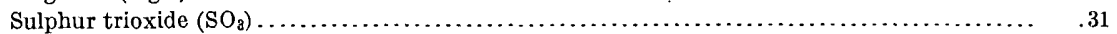

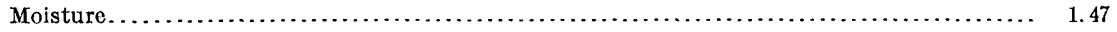

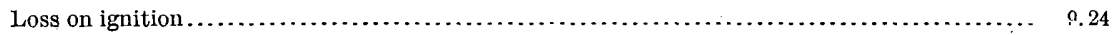

100.15

CLAYS OF THE JACKSON FORMATION (UPPER EOCENE).

Very little attention has been paid to the vast deposits of calcareous clays of the Jackson formation. The importance of these clays from an economic standpoint is yet to be determined. Some of them contain a large amount of lime carbonate, but clay with as high as 20 per cent of lime, if this is in a finely disseminated condition, can be used in making common brick, roof tiling, and in some cases stoneware and terra cotta.

The following analyses and notes on the Jackson clays were made by Dr. E. W. Hilgard: $a$

Underclay of gypseous prairie, from sec. 12, T. 6, R. 3 E. Depth, 3 to 7 feet (as far as visible) below the surface. A greenish-gray heavy clay with numerous small white specks (of gypsum) and some round concretions of iron ore.

Analysis of clay from sec. 12, T. 6, R. 4 E.

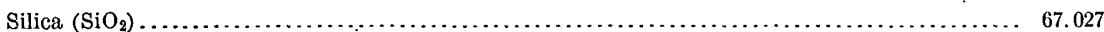

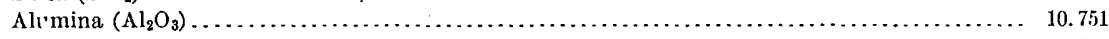

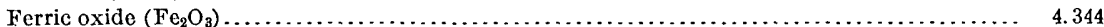

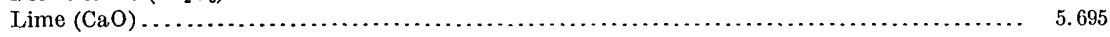

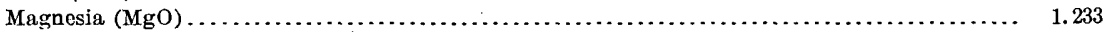

$a$ Geology and Agriculture of Mississippi, 1860, pp. 337, 340-341. 


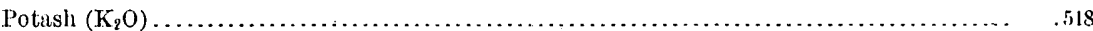

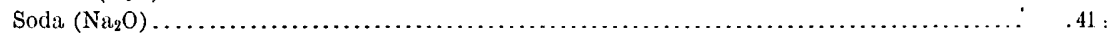

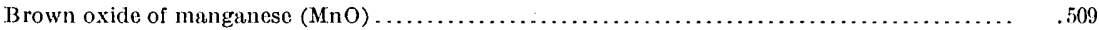

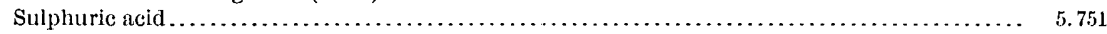

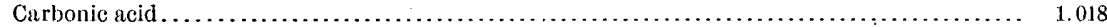

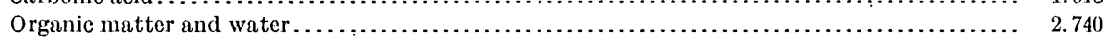

100.000

Leaf River prairie soil, taken at the crossing of the Paulding and Brandon roads in T. 4 N., R. 8 E., depth 12 inches, a very clayey soil, almost jet black, crumbling readily on exposure after wetting:

Analysis of clay from $T .4$ N.. R. 8 E.

Silica $\left(\mathrm{SiO}_{2}\right)$

63.435

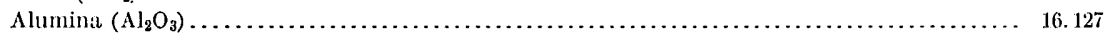

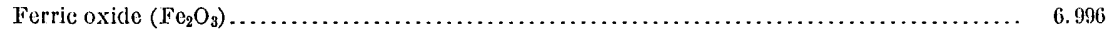

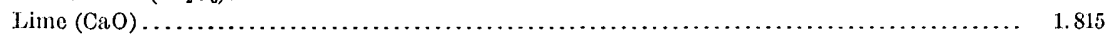

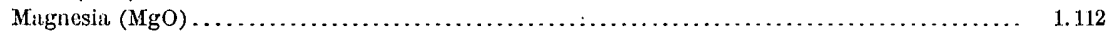

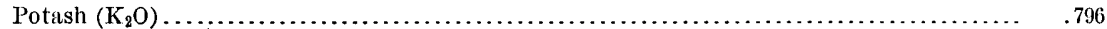

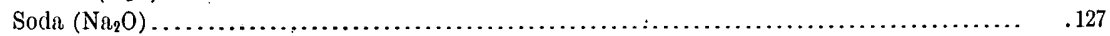

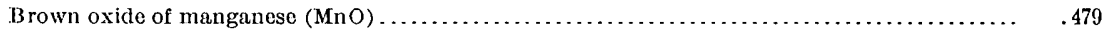

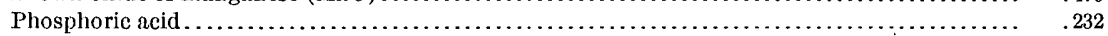

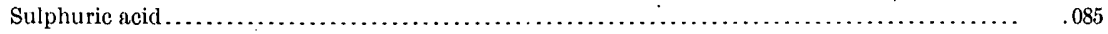

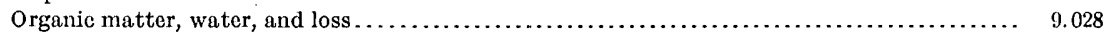

100.232

The above analyses were made from material near the surface, which may properly be considered subsoil. However, they show the character of the underclays of the Jackson formation.

\section{CLAYS OF THE GRAND GULF GROUP (MIOCENE).}

In the Grand Gulf group there are two classes of clays, which have been described under the head of "Grand Gulf group," (pp. 40-44). They are the white siliceous clays interbedded with the siliceous and aluminous sandstone of the northwestern district and the more lignitic plastic clays of the southeastern district. The entire Grand Gulf formation contains more or less clays, all of which occur in stratified beds. In places these beds reach a great thickness.

Stonington fire clay.-At Stonington, Jefferson County, occurs a large deposit of white plastic clay, which, by mixing with a more sandy clay, has been used for making pressed brick. When used alone the white clay makes a durable fire brick. The updraft kilns of the brick plant at Stonington are lined with fire brick made from this clay. It is highly plastic and burns to a cream color. The following is an analysis of this clay:

\section{Analysis of Stonington fire clay, Jefferson County.}

[By W. F. Find, State chemist.]

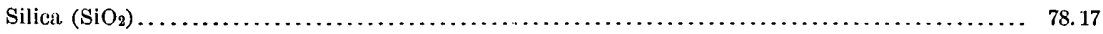

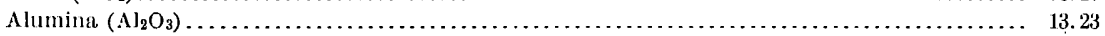

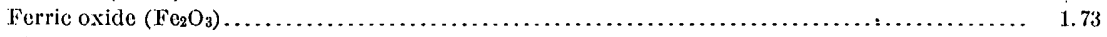

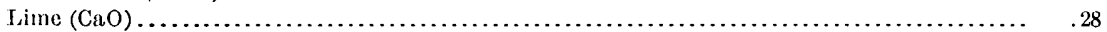

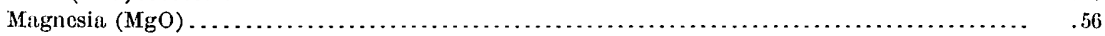

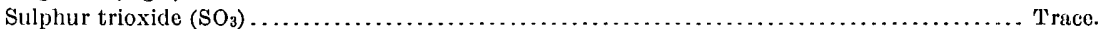

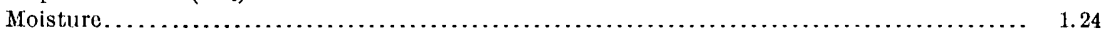

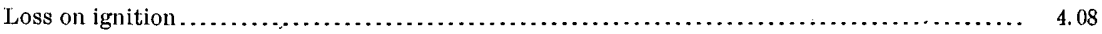

99.29

Vicksbury clay.-Five miles south of Vicksburg, on the old Roche land, a thin stratum of friable sandstone outcrops about 40 feet above the bed of the branch. Below the sandstone appears a bed of white friable clay which is derived from the decomposition of the sandstonc. Some of the fragments show the sandstone in the process of change. It is very rotten and 
can be crumbled between the fingers. The sandstone belongs to the Grand Gulf formaiion. It is underlain by calcareous beds. The thickness of the clay bed could not be determined. The following analysis shows the composition of this clay:

\section{Analysis of Vicksburg clay, Warren County.}

[By W. F. Hand, State chemist.]

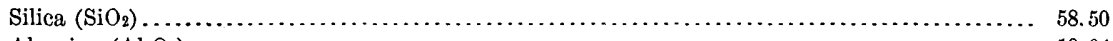

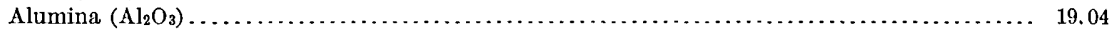

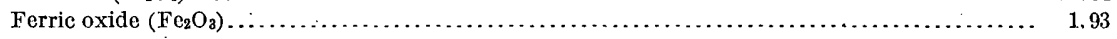

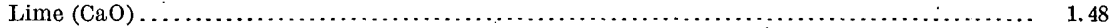

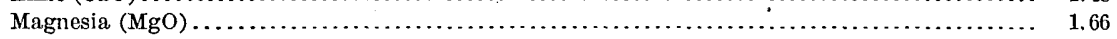

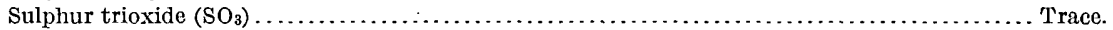

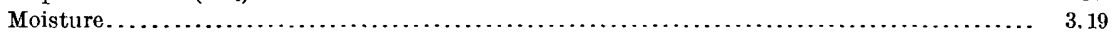

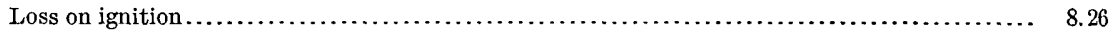

94.06

Taylorsville clay.-Five miles north of Taylorsville, on property belonging to J. S. Eaton and brother, on Fisher Creek, the typical Grand Gulf clay of the southeastern area outcrops. It is a dark-gray clay containing a large amount of carbonaceous matter, which is driven off under a high heat and the burned clay is of a buff color. A sample of the clay was sent by J. S. Eaton to the St. Louis Fire Brick Company to be tested for fire brick. It was found, however, that the clay, when used alone, cracked too much in burning. The following analysis has been made of this clay:

Analysis of Taylorsville clay, Smith County.

[By W. F. Hand, State chemist.]

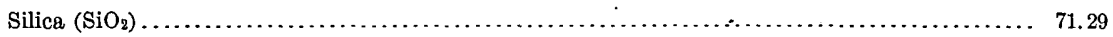

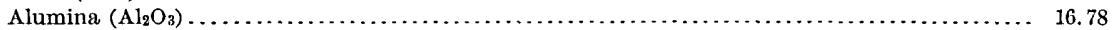

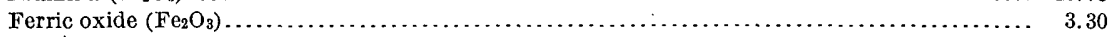

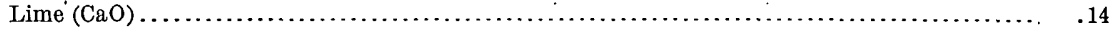

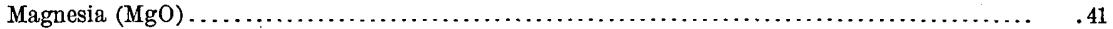

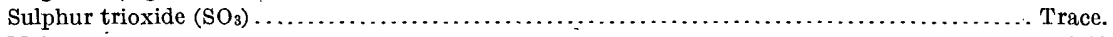

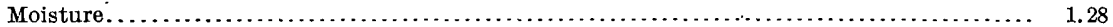

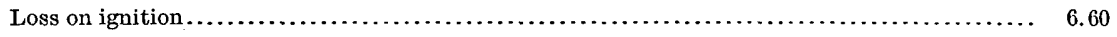

99.80

Laurel brick clay.-At Laurel, Jones County, the Lafayette is very thin and in places entirely washed away. The underlying Grand Gulf clay is dark gray to bluish in color and is well adapted to making common brick. The clay is high in silica, but contains sufficient alumina to bond it. It is claimed by the manager of the Laurel Brick Company that it is almost impossible to burn the clay too hard with wood fuel. The amount of iron in the clay causes the brick to burn to a deep-red color. The following is an analysis of the Laurel clay:

Analysis of Laurel brick clay, Jones County.

[By W. F. Hand, State chemist.]

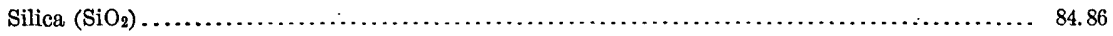

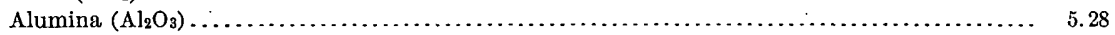

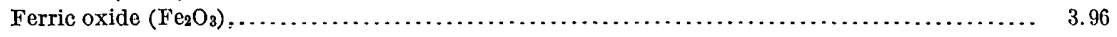

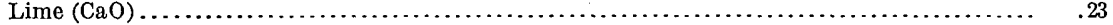

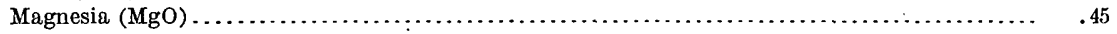

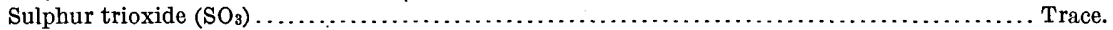

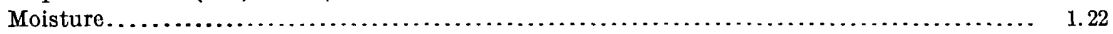

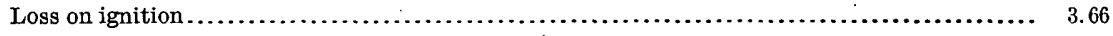

LAFAYETTE CLAYS (EARLY QUATERNARY).

The prevailing materials of the Lafayette formation are gravels and sand, but occasionally small, irregular deposits of clay are embedded in the coarse sand. The clay when present is usually greatly discolored by the presence of iron oxide, though in some places, as at Morton, Scott County, bodies of snow-white clay are found with scarcely a trace of iron. 
In certain localities of the State the surface soil formed from the Lafayette is used in making common brick, but such brick are always high in sand and a very inferior product unless the soil is mixed with a more aluminous material.

The clays of the Lafayette have received very little attention, since they are usually inferior in quality and very limited in quantity. The two samples which are mentioned below show the character of the purer clays embedded in the coarse Lafayette sands.

Brandon clay.--In the vicinity of Brandon more or less Lafayette sands overlie the older formations. Within these sands are small, irregular deposits of clay, which is usually nonplastic and highly colored, owing to the presence of iron oxide. The following is an analysis of the Brandon clay:

\section{Analysis of Brandon clay, Rankin County.}

[By W. F. Hand, State chemist.]

Silica $\left(\mathrm{SiO}_{2}\right)$ 64.79

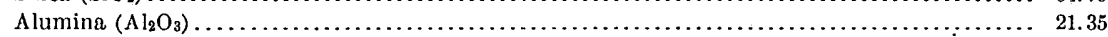

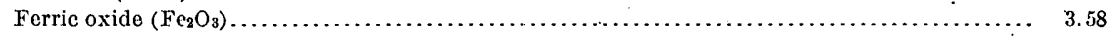

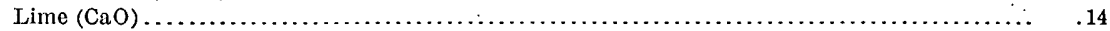

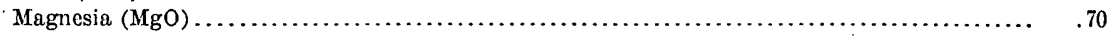

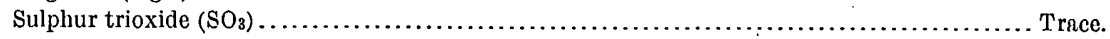

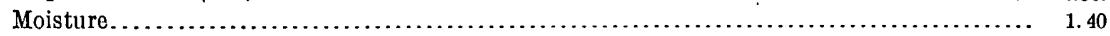

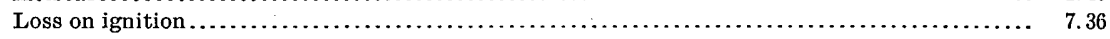

99.32

Morton clay.-One mile east-northeast of Morton, Scott County, at the old gravel pit of the Alabama and Vicksburg Railway, there is a good exposure of the Lafayette sands, pebbles, and the accompanying clay. The uppermost bed consists of Lafayette pebbles and coarse sand, $12 \frac{1}{2}$ feet thick. This is underlain by 5 feet of very plastic clay. The upper portion of the clay is interstratified with yellow to red clay and sand and the purest part is near the bottom, where it has a deep, orange-red color, with milky-white spots. The clay is often so tough that it can only be removed from the bank with the greatest difficulty. The analysis of this clay shows it to be low in silica and high in alumina, with very little ferric oxide.

Analysis of Morton clay, Scott County.

[By W. F. Hand, State chemist.]

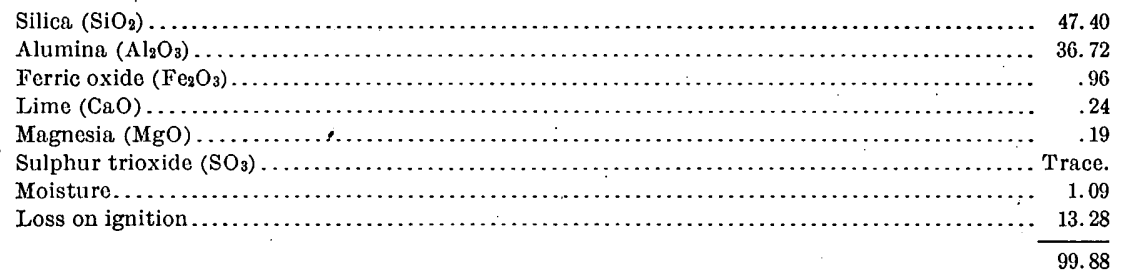

LOESS AND YELLOW-LOAM BRICK CLAYS (QUATERNARY).

The yellow loam represents the latest deposit in northern Mississippi except the more recent deposits in the Yazoo bottom and along the streams. It was called yellow or brown loam by Dr. E. W. Hilgard, and was referred to by W J McGee as the Columbia.

In northwestern Mississippi, east of the Yazoo bottom, the loess and yellow loam overlie the Lafayette and form the surface soil of the region. From this loam the brick plants at Holly Springs, Oxford, Grenada, Yazoo City, Jackson, Vicksburg, and other places obtain material for making brick. It is an excellent clay for making wet-mud and dry-pressed brick. It burns from a buff to a deep-red color. Forming the surface of so large an area, it is accessible at almost any place and can be made into brick at a minimum cost. 
A sample of the yellow loam was collected from Grenada, and the following analysis of it has been made:

\section{Analysis of yellow loam from Grenada, Grenada County.}

[By W. F. Hand, State chemist.]

Silica $\left(\mathrm{SiO}_{2}\right)$ 73.11

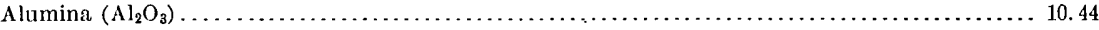

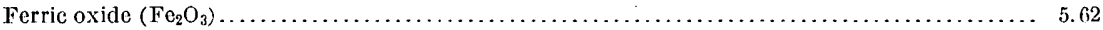

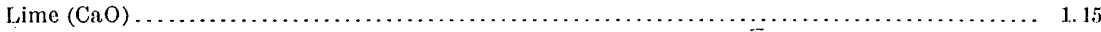

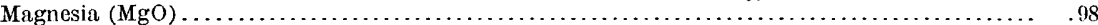

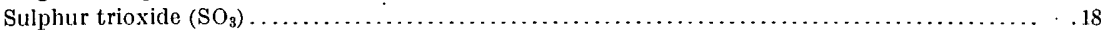

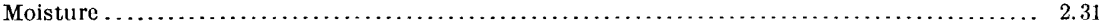

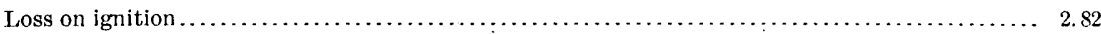

96.61

Stonington common brick clay.-The yellow loam occupies the surface in the vicinity of Stonington, Jefferson County. It is used here for making common wet-mud brick. When mixed with the underlying white Grand Gulf clay it makes a substantial fire brick. The following is an analysis of the Stonington yellow loam:

Analysis of Stonington brick clay, Jefferson County.

[By W. F. Hand, State chemist.]

Silica $\left(\mathrm{SiO}_{2}\right)$

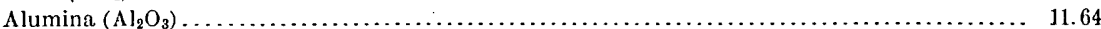

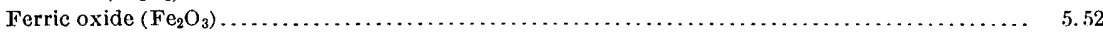

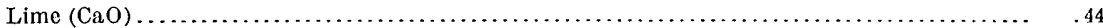

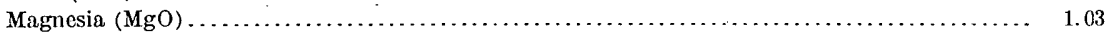

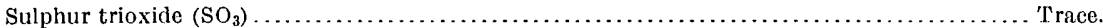

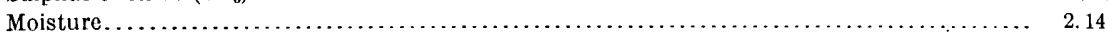

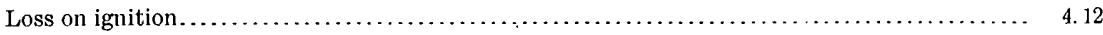

South of the area of the Lafayette formation in southern Mississippi is a much later deposit of bluish-gray to red clay, in places containing calcareous nodules. This later formation overlaps the Lafayette and forms the surface over a strip of country extending back 15 to 50 miles from the coast. On the geologic map (Pl. I, p. 6) the clay has been mapped for the present as Port Hudson, the same as the deposit forming the surface of the Yazoo delta. In places this clay is being used for making brick.

Biloxi clay.-At Biloxi, on the coast, George Orr has a small plant where he uses the Quaternary clay for making pottery. Various pieces of fancy-shaped ware are made, some of which show originality of design. The clay usually cracks on being exposed to a high degree of heat. It comes from a pit on Bayou Tchula Cabawfa, 4 miles northwest of Biloxi. The following analysis has been made of the Biloxi clay:

\section{Analysis of Biloxi clay, Harrison County.}

[By W: F. Hand, State chemist.] 73.40

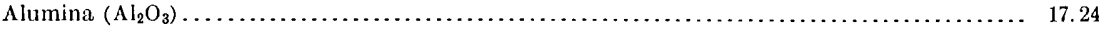

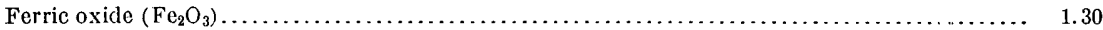

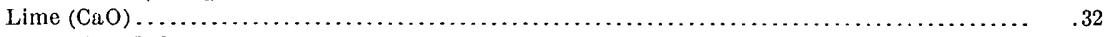

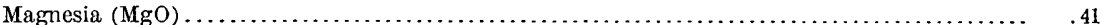

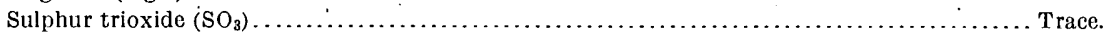

Moisture . . . . . . . . . . . . . . .

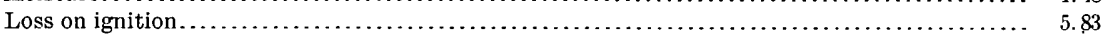

99.98

It may be of interest to note that the clay used in the Newcomb pottery, New Orleans, comes from Mississippi-the larger portion of it from Bayou Tchula Cabawfa, 5 miles from 
Biloxi. When used alone the clay is too dark for making a fine grade of ware. It is therefore mixed with a clay from Iuka, Miss., and the combination produces a lighter colored ware which has gained an enviable reputation.

\section{QUATERNARY CLAYS OF THE YAZOO DELTA.}

Only the more arenaceous and gumbo clays are found in the west-central section of the State. Over a large portion of the Yazoo delta there is a thin veneering of fine sand or silt which has been deposited during successive overflows of Mississippi River and the other strcams throughout the area. The sands and silts occur only along the banks of the present or ancient streams. The delta streams carry a large amount of suspended material and when they overflow the greater portion of the sediment is dropped near them. The banks of the streams are thus built up higher than the interstream areas. This is true of all the streams of any size throughout the country subject to overflow. The width of the superadded deposits extending back from the streams depends on the size of the streams.

The material occupying the surface of the interstream areas is a tough gray aluminous clay commonly known as "buckshot clay," though it does not always contain the small iron pebbles which have given rise to the name. When wet the clay forms a sticky mass which is a great hindrance to wagoners. It is, nevertheless, easily cultivated and puls verizes into a loose fertile soil well adapted to cotton and corn.

It has been estimated that this clay comprises 65 per cent or more of the soils of the delta. The relation of the silty loam to this gray gumbo clay is shown in the following section at Clarksdale, Coahoma County:

Section at Clarksdale brick plant.

Fi. In.

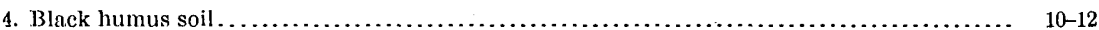

3. Light-gray sandy clay containing small flecks of mica $\ldots \ldots \ldots \ldots \ldots \ldots \ldots \ldots \ldots \ldots \ldots \ldots \ldots \ldots \ldots$

2. Fine gray siliceous sand, with irregular layers of sandy clay $\ldots \ldots \ldots \ldots \ldots \ldots \ldots \ldots \ldots \ldots$

1. Gray, stiff "buckshot clay" ...................................................

The upper 6 feet of sands and clays are united as they come from the pit, and the combined mass is used for making brick. The lowest clay member is considered too compact for making brick; it requires too much time for drying and the bricks check before drying.

One-half mile west of Clarksdale is an abandoned river channel about 1 mile in width. It is now filled up until it is but 10 to 15 feet lower than the level of Clarksdale. West of the old channel the tough gumbo clay, which is 6 feet below the surface at Clarksdale, underlies about 12 to 15 inches of humus soil. This clay has been used, after burning, as a road material, and as such will be discussed later (p. 86).

\section{CEMENT MATERIALS.}

By lidwiN C. ECKEL.

PORTLAND CEMENT,

The important building material known as Portland cement was first manufactured in England in 1824. Its name is not, as is commonly supposed, due to the fact that it is manufactured at Portland, England, Portland, Me., or Portland, Oreg., for it is not and never has been made at these points. The name "Portland" was applied to this cement because, after setting, it resembles somewhat a gray limestone extensively quarried at Portland, England. The original patents on Portland cement have long since expired, and it may. now be manufactured at any point where suitable raw materials and fuels are obtainable, and where a good market exists for the finished product.

Portland cement was first manufactured in the United States about 1875. Until 1890 the American industry showed little progress, but since that date its marvelous growth has created a widespread interest in the raw materials and in the methods of manufacture. This interest is not confined to those who have a direct financial stake in the industry, as the product is so widely used and its uses are so rapidly increasing that some knowledge of its manufacture and properties is of advintage to everyone connected, directly or indirectly, with engineering or building operations. In its importance to our present civilization 
cement is surpassed among mineral products only by iron, coal, and oil; in rate of increase in annual production during the last decade even these three products can not be compared with it. In 1890 the total production of Portland cement in the United States was 335,500 barrels, valued at $\$ 439,050$; in 1903 it exceeded $22,000,000$ barrels, while the value was over $\$ 27,000,000$.

\section{CEMENT MATERIALS IN GENERAL.}

In view of the importance of this industry, the occurrence of large deposits of good cement materials in Mississippi is a matter of great interest to the citizens of the State. The raw materials used in the manufacture of Portland cement are limestones and clays, both of which are found in satisfactory quality and quantity in several difierent parts of Mississippi.

\section{ESSENTIAL CONDITIONS.}

Portland cement is produced by burning a finely ground artificial mixture consisting essentially of lime, silica, alumina, and iron oxide, in certain definite proportions. Usually this combination is made by mixing limestone or marl with clay or shale, in which case about three times as much of the lime carbonate should be present in the mixture as of the clayey materials. The burning takes place at a high temperature, approaching $3,000^{\circ} \mathrm{F}$., and imust therefore be carried on in kilns of special design and lining. During the burning, combination of the lime with silica, alumina, and iron oxide takes place. The product of the burning is a semifused mass called clinker, and consists of silicates, aluminates, and ferrites of lime in certain definite proportions. This clinker must be finely' ground. After such grinding the resulting powder is Portland cement.

The finished product is blue to gray in color, has a specific gravity of 3 to 3.25 , and when mixed with water will harden or set.

The product must be uniform in composition and quality; and as the processes of manufacture involve certain chemical as well as physical changes, four points may be regarded as of cardinal importance in making Portland cement. These are:

1. The cement mixture must be of the proper chemical and physical composition.

2. The raw materials of which it is composed must be finely ground and intimately mixed before burning.

3. The burning must be conducted at the proper temperature.

4. After burning, the resulting clinker must be finely ground.

The methods of manufacture of Portland cement have been recently described in some detail by the present writer in several reports which are still readily obtainable. Reference should therefore be made to the reports mentioned $a$ in case information in regard to manufacturing details is desired. In the present report only such matters as directly concern the question of raw materials will be discussed.

For the purposes of the present report it will be sufficiently accurate to consider that a Portland cement mixture, when ready for burning, will consist of about 75 per cent of lime carbonate $\left(\mathrm{CaCO}_{3}\right)$ and 20 per cent of silica $\left(\mathrm{SiO}_{2}\right)$, alumina $\left(\mathrm{Al}_{2} \mathrm{O}_{3}\right)$, and iron oxide $\left(\mathrm{Fe}_{2} \mathrm{O}_{3}\right)$ together, the remaining 5 per cent including any magnesium carbonate, sulphur, and alkalies that may be present.

The essential elements which enter into this mixture-lime, silica, alumina, and iron-are all abundantly and widely distributed in nature, occurring in different forms in many kinds of rocks. It can therefore be readily seen that, theore tically, a satisfactory Portland cement mixture could be prepared by combining, in an almost indefinite number of ways and proportions, many possible raw materials. Obviously, too, we might expect to find perfect gradations in the artificialness of the mixture, varying from the one extreme, where a natural rock of absolutely correct composition was used, to the other extreme, where two or more materials, in nearly equal amounts, are required to make a mixture of correct composition.

\footnotetext{
$a$ Discussions of the materials and method of Portland cement manufacture are contained in the following three publications, all of which are distributed free of charge and may be obtained on application to the proper officials:

1. Senate Doc. No. 19, 58th Cong., 1st sess., 1903.

2. Bulletin No. 8, Alabama Geol. Survey, 1904.

3. Bulletin No. 243, U. S. Geol. Survey, 1905.
} 
The almost infinite number of raw materials which are theoretically available are, however, reduced to a very few in practice under existing commercial conditions. The necessity for making the mixture as cheaply as possible rules out of consideration a large number of materials which would be considered available if chemical composition was the only thing to be taken into account. Some materials otherwise suitable are too scarce; some are too difficult to pulverize. In consequence, a comparatively few combinations of raw materials are actually used in practice.

In certain localities deposits of argillaceous (clayey) limestone or "cement rock" occur, in which the lime, silica, alumina, and iron oxide exist in so nearly the proper proportions that only a relatively small amount (say 10 per cent or so) of other material is required in order to make a mixture of correct composition.

In the majority of plants, however, most or all of the necessary lime is furnished by one raw material, while silica, alumina, and iron oxide are largely or entirely derived from another raw material. The raw material which furnishes the lime is limestone, chalk, or marl, while the silica, alumina, and iron oxide of the mixture are derived from clay, shale, or slate.

Determining the possible value for Portland cement manufacture of a deposit of raw material is a complex problem, depending on a number of distinct factors, all of which must be given due consideration. The more important of the factors are:

1. Chemical composition of the material.

2. Physical character of the material.

3. Amount of material available.

4. Location of the deposit with respect to transportation routes.

5. Location of the deposit with relation to fuel supplies.

6. Location of the deposit with respect to markets.

Ignorance of the respective importance of these factors frequently leads to an overestimate of the value of a deposit of raw material. Their effects may be briefly stated as follows:

\section{CHEMICAL COMPOSITION.}

The raw material must be of correct chemical composition for use as a cement material. This implies that the material, if a limestone, must contain as small a percentage as possible of magnesium carbonate. Under the present conditions 5 or 6 per cent is the maximum permissible. Free silica, in the form of chert, flint, or sand must be absent, or present only in small quantities, say 1 per cent or less. If the limestone is a clayey limestone or "cement rock," the proportion between its silica and its alumina and iron should fall within the limits:

$$
\frac{\mathrm{SiO}_{2}}{\mathrm{Al}_{2} \mathrm{O}_{3}+\mathrm{Fe}_{2} \mathrm{O}_{3}}>2 \text { and } \frac{\mathrm{SiO}_{2}}{\mathrm{Al}_{2} \mathrm{O}_{3}+\mathrm{Fe}_{2} \mathrm{O}_{3}}<3.5
$$

A clay or shale should satisfy the above requirement and should be free from sand, gravel, etc. Alkalies and sulphates should, if present, not exceed 3 per cent or so:

The nearer a limestone approaches in composition to the mixture used in Portland cement manufacture the greater its value for that purpose, for it will require the addition of less extraneous material to make the mixture absolutely correct in composition. The following are analyses of Portland cement mixtures, ready for burning, as used at various large cement plants in the United States:

Analyses of Portland cement mixtures.

\begin{tabular}{|c|c|c|c|c|}
\hline . & 1. & 2. & 3. & 4. \\
\hline Silica $\left(\mathrm{SiO}_{2}\right) \ldots \ldots \ldots \ldots \ldots$ & 12.85 & 12.92 & 13.52 & 14.94 \\
\hline Alumina $\left(\mathrm{Al}_{2} \mathrm{O}_{8}\right) \ldots \ldots \ldots \ldots \ldots \ldots \ldots \ldots$ & 4.92 & 4.83 & 6.56 & 2.66 \\
\hline Iron oxide $\left(\mathrm{Fe}_{2} \mathrm{O}_{3}\right) \ldots \ldots \ldots \ldots \ldots \ldots \ldots \ldots$ & 1.21 & 1.77 & …... & 1.10 \\
\hline Lime carbonate $\left(\mathrm{CaCO}_{8}\right) \ldots \ldots \ldots \ldots \ldots \ldots \ldots \ldots$ & 76.36 & 75.53 & 75.13 & 75.59 \\
\hline Magnesium carbonate $\left(\mathrm{MgCO}_{3}\right) \ldots \ldots \ldots \ldots \ldots \ldots \ldots$ & 2.13 & 4.34 & 4.32 & 4.64 \\
\hline
\end{tabular}


It will be seen that the usual mixtures carry from 75 to 77 per cent of lime carbonate. With this in mind, it will be obvious that there is a great advantage in using, as one of the raw materials, a limestone of about this degree of purity.

\section{PIIYSICAL COMPOSITION.}

Economy in excavation and crushing requires that the raw materials should be as soft as possible. This condition is admirably met by the chalky limestones of the Tombigbee River district, and they should show a considerable saving in crushing costs as against the hard limestones used in many northern plants.

\section{AMOUNT AVAILABLE.}

A Portland cement plant running on dry raw materials, such as a mixture of limestone and shale, will use approximately 20,000 tons of raw material per year per kiln. Of this about 15,000 tons are limestone and 5,000 tons shale: Assuming that the limestone weighs 160 pounds per cubic foot, which is a fair average weight, each kiln in the plant will require about 190,000 cubic feet of limestone per year. As the shale or clay may be assumed to contain considerable water, a cubic foot will probably contain not over 125 pounds of dry material, so that each kiln will also require about 80,000 cubic feet of shale or clay.

A cement plant is an expensive undertaking, and it would be folly to locate one with less than a twenty years' supply of raw material in sight. This would require that, to justify the erection of a cement plant on any property, for each kiln of the proposed plant there must be in sight at least $3,800,000$ cubic feet of limestone and $1,600,000$ cubic feet of clay or shale.

LOCATION WITH RESPECT TO TRANSPORTATION ROUTES.

Portland cement is, for its value, a bulky product, and its economic manufacture is therefore much influenced by the subjecț of transportation routes. To locate a plant on only one railroad, unless the railroad officials are financially connected with the cement plant, is simply to invite disaster. At least two transportation routes should be available, and it is best of all if one of them be a good water route.

\section{LOCATION WITH RESPECT TO FUEL SUPPLIES.}

Every barrel (380 pounds) of Portland cement marketed implies that at least 200 to 300 pounds of coal have been used in the power plant and the kilns. In other words, each kiln in the plant will, with its corresponding crushing machinery, use up from 6,000 to 9,000 tons of coal per year. The item of fuel cost is therefore highly important, for in the average plant about 30 to 40 per cent of the total cost of the cement will be chargeable to coal supplies.

The fuel most commonly used in modern rotary-kiln practice is bituminous coal pulverized very finely. Coal for this purpose should be high in volatile matter and as low in ash an 1 sulphur as possible. Russell gives the following analyses of West Virginia and Pennsylvania coals used at present at various cement plants in Michigan:

Analyses of kiln coals.

\begin{tabular}{|c|c|c|c|c|}
\hline & 1. & 2. & 3. & 4. \\
\hline Fixed carbon..... & 56.15 & 56.33 & 55.82 & 51.69 \\
\hline Volatile matter........... & 35.41 & 35.26 & 39.37 & 39.52 \\
\hline$A \operatorname{sh} \ldots \ldots \ldots \ldots \ldots \ldots \ldots \ldots \ldots \ldots \ldots \ldots$ & 6.36 & 7.06 & 3.81 & 6.13 \\
\hline 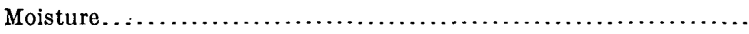 & 2.08 & 1.35 & 1.00 & 1. 40 \\
\hline 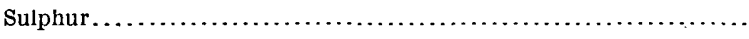 & 1.30 & 1.34 & .42 & 1.46 \\
\hline
\end{tabular}




\section{LOCATION WITII RESPECT TO MARKETS.}

In order to secure an established position in the trade, a new cement plant should have (a) a local market area within which it may sell practically on a noncompetitive basis, and (b) ensy access to a larger though competitive market area.

\section{COST OF EQUIPMENT AND ERECTION.}

Exclusive of costs of land, the cost of equipping and erecting a good plant will fall within the limits of $\$ 50,000$ and $\$ 80,000$ per kiln. These limits may seem wide, but it is difficult to make a closer general estimate. 'Two plants recently built cost as follows: 4-kịln plant, total cost $\$ 287,000$; cost per kiln, $\$ 71,750$; 6 -kiln plant, total cost $\$ 373,000$; cost per kiln, $\$ 62,167$.

For small plants of two to six kilns each such costs would not be exceptional. For larger plants it is to be remembered that the cost per kiln decreases with the increase in the number of kilns. The following table of average costs will exemplify this, and may be of use as a basis for general estimates:

TOTAL CAPITAL REQUIRED.

The amount of capital. required to properly float a cement proposition is considerably in excess of the costs of land, construction, etc. The principal causes of this condition are:

(a) It is within bounds to say that the average cement plant will not produce normal cement at a normail cost for a considerable period (varying from three to six months, or even longer) after the plant is first put into operation. Both the machinery and the personnel of the plant will require numberless (though individually small) alterations before good work can be accomplished. The plant must be carried through this profitless and expensive period entirely on its reserve capital.

(b) It is becoming more and more the fashion among engineers to judge a cement by its past record, and to refuse bids from a plant not possessing a record of success in actual work. Even after the plant is working normally, therefore, steady sales can not be counted on for some time. The intervening time can, of course, be devoted to filling large stock houses, but this brings in no ready money to the plant.

(c) Cement is sold on comparatively long time, while many of the expenses of the plant must be paid in cash. This is particularly the case with regard to quarry and mill labor, an item which alone in a 6-kiln plant may amount to from $\$ 4,000$ to $\$ 6,000$ per month.

For these reasons it is advisable to make a very liberal allowance for the working capital required. A reserve amounting to from $\$ 20,000$ to $\$ 25,000$ per kiln would probably be found sufficient to cover most cases. This will increase the capital necessary so that it will be essential to allow about $\$ 100,000$ per kiln to cover costs of erection, working capital, etc.

\section{CEMENT MATERIALS OF MISSISSIPPI.}

No cement of any type has ever been manufactured in Mississippi, but several large limestone areas occur in the State, and at least one of these is so well located with respect to fuel, supplies, and transportation routes as to give promise of being of future importance as a. source of Portland cement material.

The available limestones of the State may be grouped and described under three heads, the second being the most promising as the possible basis of a cement industry.

The three groups noted are:

(1) Mississippian (Lower Carboniferous) limestones.

(2) Cretaceous limestones (Selma chalk or "rotten limestone"). 
(3) Tertiary limestones (Vicksburg limestone).

The distribution of these formations is shown on the geologic map (Pl. I), which is based on recent work by the United States Geological Survey in Mississippi.

\section{MISSISSIPPIAN (LOWER CARBONIFEROUS) LIMESTONES.}

In the extreme northeast corner of Mississippi, in the counties of Itawamba and Tisho-mingo, there is a small area of Devonian and Carboniferous rocks. These include shales, thin sandstones, and limestones. The limestones, which are mainly of Mississippian (Lower Carboniferous) age, are frequently low in magnesia, and are otherwise suitable for use as Portland cement material. At present, however, the most promising localities of these limestones have no adequate transportation facilities. This fact, together with the nearness of the soft and easily crushed Selma chalk, will probably serve to prevent the utilization of the Carboniferous limestones for some time.

The following analysis of a limestone from Cypress Pond, Tishomingo County, is by Dr. E. W. Hilgard:

\section{Analysis of Mississippian limestone.}

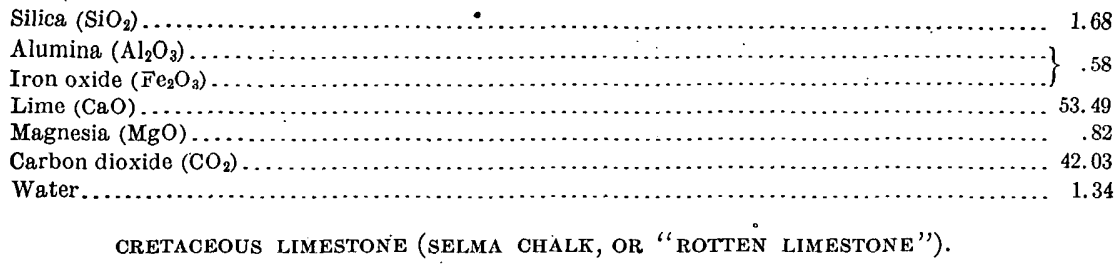

The Selma formation of the Cretaceous is a thick series of chalks, chalky limestones, and more or less limy clays, which are well exposed in northeastern Mississippi. The arca occupied by these limestones in Mississippi is shown in Pl. I.

Thickness.-The Selma chalk attains its maximum thickness in central Alabama, reach. ing a total of about 1,200 feet. To the west it decreases slightly in thickness, the well : $t$ Livingston, Sumter County, Ala., giving a total of 930 feet, while the well at Starkville, Oktibbeha County, Miss., taken in connection with surrounding outcrops, indicates a thickness of at least 700 feet. As the belt turns northward toward Tennessee the formation decreases rapidly in thickness, while at the same time the limestone beds contained in it become fewer and thinner, until in Tennessee the Selma is a thin series of somewhat calcarzous clays, with only occasional beds of chalk.

Stratigraphy.-Owing to the rapidity with which it disintegrates when exposed to atmospheric action, surface outcrops give comparatively little information in regard to the stratigraphy of this formation. Fortunately, a very precise section of the Selma chalk, taken at a point where it is almost of maximum thickness, is in existence. This is embodied in the record of a well drilled at Livingston, Sumter County, Ala., and quoted by Dr. E. A. Smith in his Report on the Geology of the Coastal Plain of Alabama, pages 277-278. The well was located just south of the boundary between the Selma and Ripley formations, and reached a depth of 1,062 feet, so that it passed through the entire thickness of the Selma chalk and into the underlying Eutaw formation.

The section of this well is given below. The upper 20 feet are, according to Smith, probably in part Lafayette and in part Ripley. From a depth of 20 to 950 feet the well was in the Selma formation, while from 950 to 1,062 feet it was in the Eutaw. 
Section of well at Livingston, Sumter County, Ala.

\begin{tabular}{|c|c|c|}
\hline & \begin{tabular}{|} 
Thick- \\
ness.
\end{tabular} & Depth. \\
\hline Lafayette and Ripley: & Feet. & F'eet. \\
\hline Sandy loam....... & 1 & \\
\hline 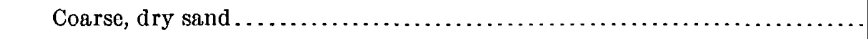 & 12 & $1-13$ \\
\hline White quicksand ....................... & 7 & $13-20$ \\
\hline \multicolumn{3}{|l|}{ Selma chalk: } \\
\hline Soft blue limestone, many shells and py rịte nodules...... & 180 & $20-200$ \\
\hline White limestone, harder, few shells or pyrite nodules.................. & 50 & $200-250$ \\
\hline Fard blue limestone, no shells or nodules......................... & 7 & $250-257$ \\
\hline Bluish-white limestone, less hard, no shells or nodules.............. & 68 & $257-325$ \\
\hline 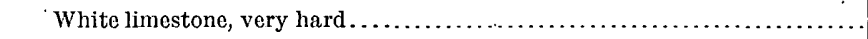 & 55 & $325-380$ \\
\hline Light-blue limestone, softer ............. & 47 & $380-427$ \\
\hline Bluish-brown rock, small shells, some sand.. & 58 & $427-485$ \\
\hline Fard white limestone.................... & 105 & $485-590$ \\
\hline Soft reddish-brown rock............. & 2 & $590-592$ \\
\hline Soft deep-blue rock................... & 20 & $592-612$ \\
\hline Brownish-blue rock, moderatcly soft . . . . . . . & 78 & $612-690$ \\
\hline Hard, gritty blue rock...................... & $\frac{1}{2}$ & $690-690 \frac{1}{2}$ \\
\hline Dark-bluish rock, soft........... & $9 \frac{1}{2}$ & $690 \frac{1}{2}-700$ \\
\hline Soft whitish limestone..... & 250 & $700-950$ \\
\hline \multicolumn{3}{|l|}{ Eutaw sands: } \\
\hline Hard sandstone.. & 6 & $950-956$ \\
\hline Sand...$\ldots \ldots \ldots \ldots$ & 10 & $956-966$ \\
\hline Sand rock...................... & 1 & $966-967$ \\
\hline Coarse greensand........... & 38 & $967-1,005$ \\
\hline Sandstone...................... & 2 & $1,005-1,007$ \\
\hline Greensand..................... & 25 & $1,007-1,032$ \\
\hline 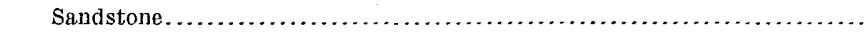 & 2 & $1,032-1,034$ \\
\hline Coarse greensand $\ldots \ldots \ldots \ldots \ldots \ldots \ldots \ldots \ldots \ldots$ & 18 & $1,034-1,052$ \\
\hline 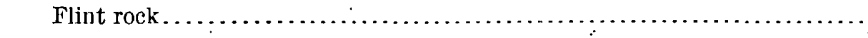 & 1 & $1,052-1,053$ \\
\hline 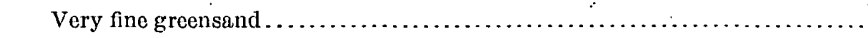 & 9 & $1,0.53-1,062$ \\
\hline
\end{tabular}

Description of localities.-During 1904 the Selma chalk was carefully mapped throughout the Tombigbee River basin. The result of this mapping is shown in Pl. I. In the following pages descriptions will be given of the various localities visited during this work. Samples were taken from all of these localities, and many of these samples have been analyzed, the results being given below. The descriptions are given in order, going up Tombigbee River from the Alabama-Mississippi line.

At the big elbow bend in Oaknoxubee River, one-fourth mile below the wagon bridge at Macon, the river has formed on its south side a bluff 75 feet high. The entire cliff is made up of the Selma chalk. It is a solid mass of white chalk, nonfossiliferous, and apparently without bedding planes, but viewed at a distance the stratification of the material is shown by the unequal hardness of the strata, causing some to weather more rapidly than others. There is a marked dip to the south. All the smaller streams flowing into the Oaknoxubee have channeled their beds into the pure white limestone. A sample was collected from the bluff on Oaknoxubee River and has been analyzed in the laboratory of the United States Geological Survey, as follows:

Analysis of Selma limestone from bluff near Macon.

[By W. S. McNeil.]

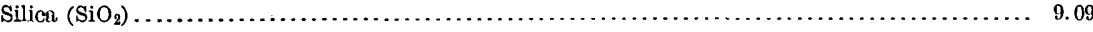

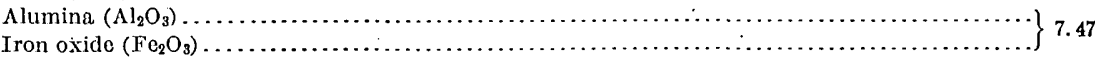

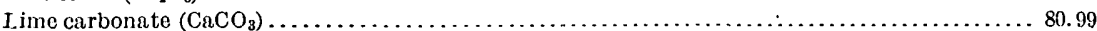

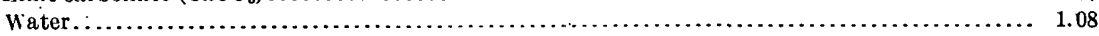


The town of Scooba is in the Flatwoods area, which is underlain by clays of the Midway group. The road from Scooba to De Kalb is through the Porters Creek area until Sucarnochee Creek is reached, 2 miles east of De Kalb. The hills of the Wilcox formation begin just west of the creek and rise 250 feet above it, barometric reading. The material here forming the Flatwoods is a gray, plastic, nonfossiliferous clay ("popping clay"). It makes a cold soil, very sticky and plastic when wet, and when it dries out cracks open so that one can thrust his hand 6 or 8 inches into the opening.

But little of the Flatwoods area is cleared and put in cultivation, and this only where there is a little remnant of Lafayette sand left. The Lafayette formation is practically wanting over the entire area of the Flatwoods. The timber is short-leaf pine, post oak, scrub hickory, black jack, and black gum, with an occasional white oak and holly.

Two and one-half miles east of Scooba, on the west bank of the creek shown on the map (Pl. I), is the first outcrop of Selma chalk on the Scooba and Gainesville road. A sample of limestone taken from this outcrop was analyzed in the laboratory of the United States Geological Survey, with the following result:

Analysis of Selma limestone from creek near Scooba.

[By W. S. McNeil.]

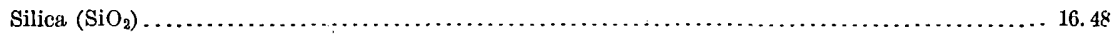

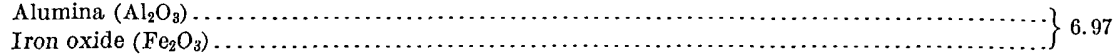

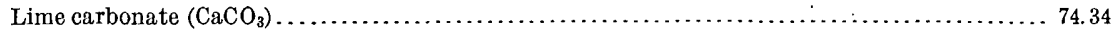

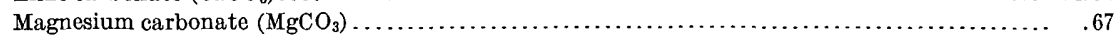

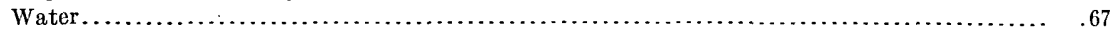

There is a change in the character of timber as soon as the Selma area is reached. Shortleaf pine, which occurs so abundantly in the Flatwoods, is wanting except in the old "turnedout land." Black oak is the principal timber in the Selma chalk. Some post oak and hickory occur. The pine is wanting at a distance of 2 miles east of Scooba, which would perhaps bring the contact between the Selma and Porters Creek one-half mile west of the Selma outcrop.

Two miles east of Scooba and one-half mile south is another outcrop of limestone, more sandy than that $2 \frac{1}{2}$ miles east of Scooba. This is perhaps of Ripley age.

Between Portersville and Oakgrove, in southern Kemper County, on the west side of Pittiefaw Creek, the Wilcox hills begin and extend westward. On land belonging to M. L. Nailer a bed of lignite, reported to be 4 feet thick, has been opened.

Sucarnochee Creek marks the west edge of the Porters Creek group from $2 \frac{1}{2}$ miles due east of De Kalb to about 3 miles north of Oakgrove. Here the Porters Creek area widens and its west edge swings in to within $2 \frac{1}{2}$ or 3 miles east of Oakgrove, then follows a southeasterly direction and crosses the Kemper and Lauderdale County line about $3 \frac{1}{2}$ miles west of the State line.

On the west side of Quilby Creek, where it runs south along the State line, 7 miles east of Sucarnochee, the Selma chalk forms a small bluff. The prairie soil extends back for 2 miles farther west. On the east side of the creek, about 100 yards east of the Alabama line, the Selma forms a bluff a little higher than on the opposite bank in Mississippi. Here what is taken to be the top of the Selma chalk is found. The top of the bluff is capped by a coarsegrained sandstone, cemented by lime carbonate. In it are lime concretions the size of a closed hand.

The upper beds of the Selma chalk also appear in the bluff on the east side of Quilby Creek, 7 miles east of Sucarnochee.

An outcrop of Selma chalk shows on the Scooba and Fox Prairie road where it crosses Bodea Creek, about 2 miles west of the State line. A samplo collected from this outcrop was analyzed in the laboratory of the United States Geological Survey, as follows: 
Analysis of Selma trin: estone from Bodea Creek, near Scooba.

[ [By W. S. McNic].]

Silica $\left(\mathrm{S}^{\mathrm{O}} \mathrm{O}_{2}\right)$

Alurnina $\left(\mathrm{Al}_{2} \mathrm{O}_{3}\right)$

(n.

82.47

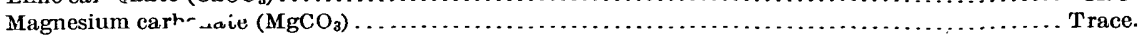

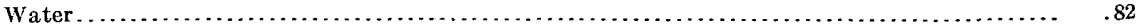

Three miles north of Scooba the western border of the Selma chalk outcrops in a series of hills forining the south bank of Wahalak Creek. The bottom of the-Waheluk is here $1 \frac{1}{2}$ miles wide, the south bank reticatuing more rapidly than the north side. The creek hias cut its channel into the Selma chalk, which outcrops almost continuously 'hröughout its course. The limestone occurs up the creek about $6 \frac{1}{2}$ to 7 miles northwest of Wahalak, but the Porters Creek clay occupies the country on both sides of the creek. The hill just east of Wahalak is of Porters Creek clay, which is not over 15 feet thick.

A sample of limestine was collected fion the bed of Wahalak Creek, about $1 \frac{1}{2}$ miles south of Wahalak. This sample was analyzed in the laborntory of the United States Geological Survey, with the following-results:

Analysis of Selma iimestone from Wataalak Creek, near Wahalak.

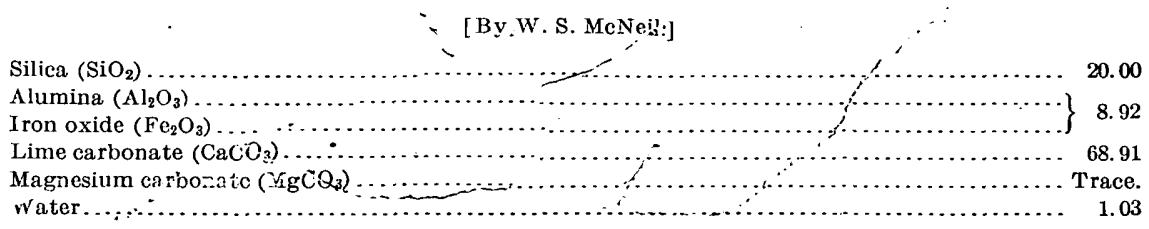

A sainple of the Selma limestone was taken from the bed of Wahalak Creek, $1 \frac{1}{2}$ miles south of the town, and on the range of low hills south of Wahalak Creek, $1 \frac{1}{2}$ miles southeast of the puint whore the Mobile and Ohio Railroad crosses the creek, another sample was taken. At the top of the Selma chalk there is about 10 feet of a sand rock cemented with lime carbonate, which contains numerous little bivalve shells. This is the same kind of stone as that found 7 miles east of Sucarnochee. There is no evidence of any Clayton limestone anywhere from Wahalak to the Alabama line, and this is the only place where the sandstone was seen in Mississippi. This doubtless belongs to the Ripley.

The Porters Creek or Flatwoods clay is well shown near Scooba. A sample collected was analyzed in the laboratory of the United States Geological Survey. The result is of interest, because clays of this type occur everywhere near the western edge of the Selma limestone area, and such clays will be needed to reduce the percentage of lime carbonate found in some of the purer samples of Selma chalk.

\section{Analysis of Midway clay from Scooba.}

[By W. S. MeNeil.]

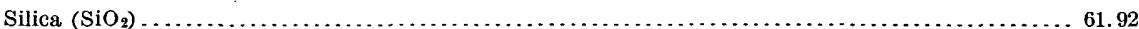

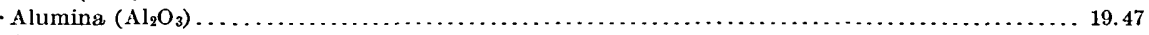

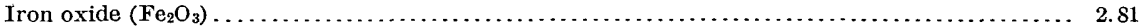

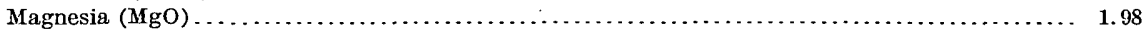

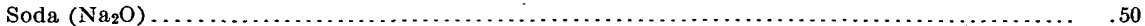

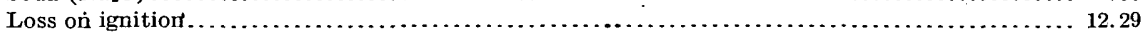

A sample of Selma chalk was taken from an old rock quarry situated on the southwest side of Bogue Chitto Creek,one-half mile east of Prairie Rock. This limestone differs from that along Oaknoxubee River, in the vicinity of Macon, in that it is much harder. In the unweathered state of the Macon rock, it is very soft and noncrystalline. One can easily stick a pick into it. But the limestone at Prairie Rock is a hard so-called "flint rock," crystalline in character, and is used for building purposes. The rock at Macon, when exposed to the 
weather, becomes white as chalk; that at Prairie Roc $\dddot{\kappa}$ weathers to a dirty tains some traces of iron stain on the weathered surfaces. This is cue to the vididation of the iron sulphide (pyrite), which is found in small concretions in the fresh rock.

An analysis of this Prairie Rock limestone, made in the laboratory of the United States Geological Survey, follows. It will be seen that the stone is a very pure limestone, in spite of the manner in which it discolors on weathering.

Analysis of Selma limestone from Prairie Rock.

[By W. S. McNeil.]

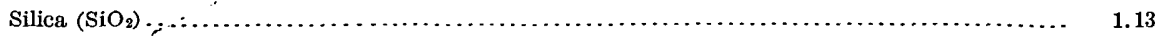

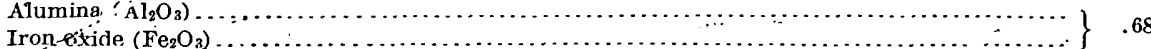

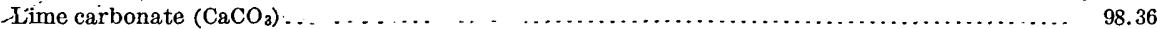

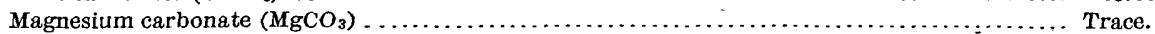

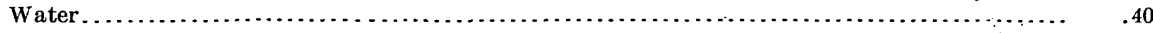

The rock breaks down easily when exposed to the weather, and hence is not now used for extensive building purposes. It is, however, the only road materizl found in this section of the country. It has been - nsed on the across Bogue Chitto swamp, but is unsetisfactory.

Men familiar with the country say that this hard limestone is very thin-only about 4 feet thick-and occurs near the surface. . Below this inärd stratỵm comes the soft, whiter "rotten limestone," which is, on an average, 20 feet thick and is underlain by the "blue rock," which holds water. In digging cisterns, the farmers a Fivays dig down to the "blue rock," which requires no curbing.

There are two kinds or soils in the prairie section, giving rise respectively to the "postoak" land and the "prairie" proper. The former is the highest Jand between the stream divides, which has suflered but little erosioii. It is very level, sloping gently to the streams.' This post-oak land is covered with a thin coating of Lafayette clayey sand, never ovier 10 feet thick, which has never been all carried away by erosion. The uncleared land produces post-oak and some black-oak timber. The "prairie" land is that from which the Lafayette has been removed, so that the black, rich loam, formed from the decomposition of the Selma chalk, is at the surface. The limestone never comes to the surface except along the streams.

When the country was first settled this black prairie soil was too strong for cotton. It produced a large stalk, but very little cotton. Until recent years all the cotton was planted on the poorer "post-oak" lands, and the prairie lands were put in corn. But after years of continuous crops of corn the prairie land became the best cotton land, and now the finest cotton grows on the prairie lands.

Later investigation around Columbus and Aberdeen has verified the fact that the land known by all as the "post-oak land," as distinguished from the black "prairie soils," is the land from which the entire Lafayette has not been removed. The soil is not so rich as the prairie soils, and has been largely abandoned for cultivation.

The following well sections are of interest in this connection:

Well at Ravine, on land of J. Q. Poindexter.

Feet.

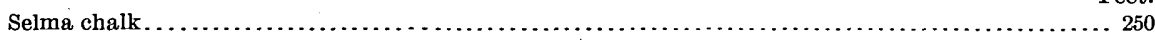

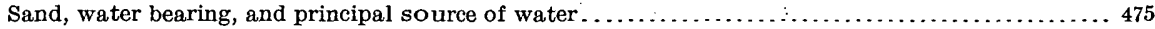

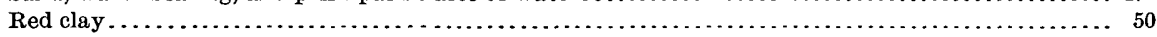

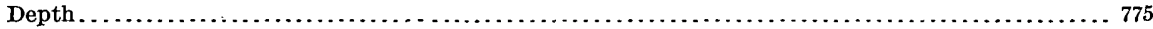

Water rises within 26 feet of surface. Water soft.

Well 2 miles due east of Ravine, on Sebe Gavin's land.

Feet.

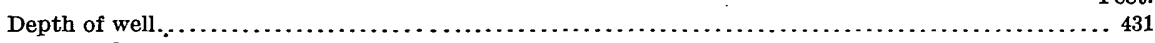

Water flows 16 feet above surface.

Well on Doctor Patty's land, near Bigbee Valley post-office.

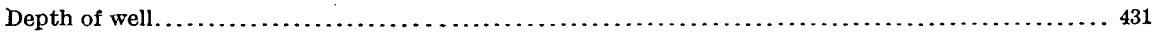

Water flows 20 feet above surface. Water found in sand, and soft. 
Depth of well

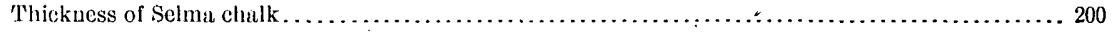

Water flows 20 feet above surface.

Well in sec. 21, T. 16, R. $19 \mathrm{E}$.

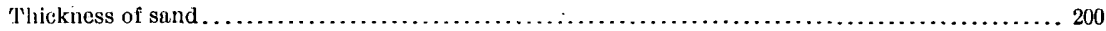

Flows.

Well at Cliftonville.

Feet.

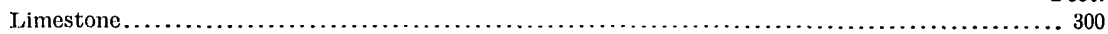

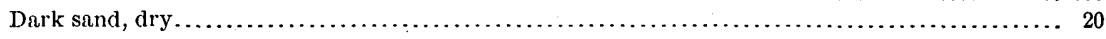

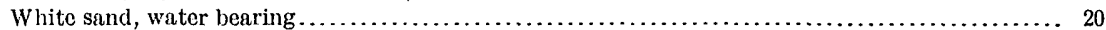

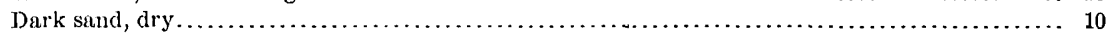

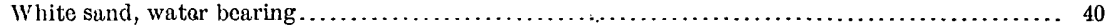

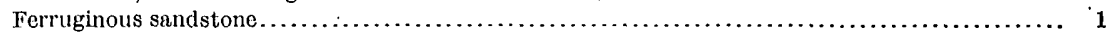

Depth of well, 450 feet; 300 feet in limestone, 150 feet in sand.

Source of water, greensand.

Well on A. G. Cunningham's land, $1 \frac{1}{2}$ miles west of mouth of James Creek.

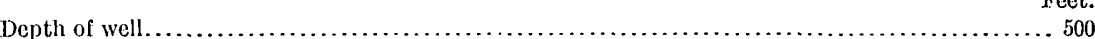

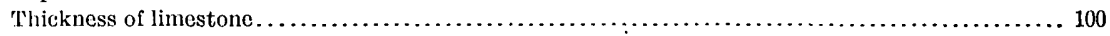

Well is 75 feet above Tombigbee River. Water overflows.

Well at Pickensville, Ala., on land of Will Rodgers.

Flows.

All the wells mentioned above except the first one were drilled by J. B. Cunningham, of Cliftonville, Miss., and the records were obtained from him. The well drillers fail to make any distinction between the lower Selma and the upper Eutaw, so that their records can not be depended on for determining the thickness of the Selma.

A sample of sandy limestone was obtained from the mouth of James Creek, on Tombigbee River. Along the Tombigbee at the mouth of this creek there is an exposure of a greensand clay containing a large amount of lime. Fifty feet above the river, $1 \frac{1}{2}$ miles west of the mouth of James Creek, another sample of limestone was collected. This limestone is similar in color and general aspect to that on the Tombigbee, except that it has less greensand.

Farther west the limestone rarely shows at the surface. It is clayey in character and easily dissolved by the weatbering agents, so that it breaks down into soil faster than it is carried away by erosion.

At Cliftonville, which is 75 feet above Tombigbee River (barometric reading), there is a hard cap rock, 2 to 4 feet thick, found on top of the hills in the vicinity of the town. This is a hard "lime" rock, similar to that found at Prairie Rock. Below this hard cap rock comes what is called the "blue rock." A sample of it seen at a well dug years ago shows that it contains no sand. Where the blue rock comes to the surface it forms a belt of the richest soil in the prairie region. The soil is very deep, black, and loose. More cotton and corn are raised to the acre here than in any other section of the State.

West of this region the land becomes higher, and the Lafayette occupies the surface on the ridges.

Six miles north of Macon, on the Macon and Columbus road, the limestone begins to show at the surface in small gullies. The rock is harder than the blue rock along the Tombigbee, and therefore occurs more frequently. A sample collected from this locality was analyzed in the laboratory of the United States Geological Survey, as follows:

Bull. $283-06-6$ 
Analysis of Selma limestone from 6 miles north of Macon.

[Bj W. S. McNeil.]

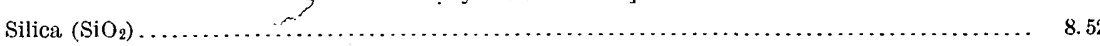

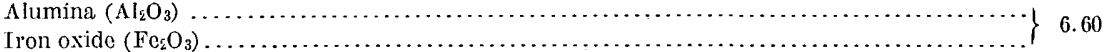

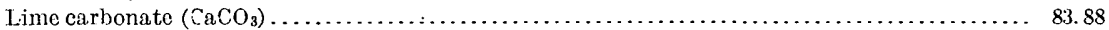

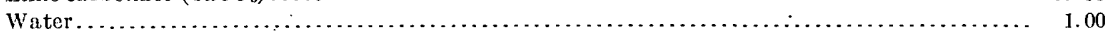

Farther south, along the Macon and Columbus road, the limestone begins to show in every gully and on every hillside. At some places on level ground the soil is not over 12 inches deep. In this vicinity are the bald.prairies, where large areas of this white limestone are exposed without a particle of soil or a blade of grass. A sample of the rock was taken 3 miles north of Macon.

A sample of Selma limestone was taken at a point north of Lime Rock, 5 miles east of Shuqualak, on Oaknoxubee River, where a bluff 50 feet high is composed of typical Selma chalk. The following analysis of this sample was made in the laboratory of the United States Geological Survey:

\section{Analysis of Selma limestone from bluff near Shuqualak.}

[By W. S. MeNeil.]

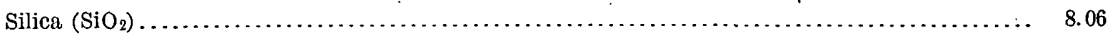

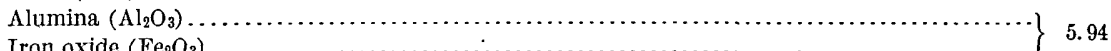

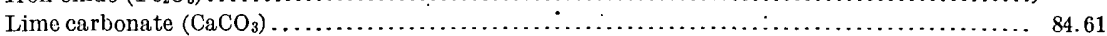

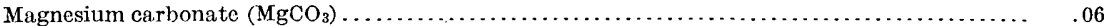

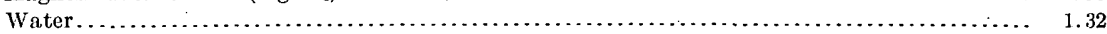

Tombigbee River at Columbus has cut its channel into the Eutaw sands, forming a bluff on the east side 90 feet high. The material composing the bluff here is a sand that is greenish when wet and gray when dry. It contains a small amount of lime carbonate. In the upper part of the bluff the sands are of lighter color and at the top they are a light golden yellow. This was the color of the sand when deposited and is not due to oxidation. Numerous little branching concretions, which are perhaps some kind of badly preserved fossils, occur in the lower portion near the water. The upper part of the sands contains two species of large oysters, which also occur in the Selma. The river at the town is now hugging the east bluff, and the bottom, which is 3 miles wide, is all on the west side. A short distance above the town, however, the reverse is true, the bluff being on the west side and the bottom on the east. At the west edge of the bottom the heavy, black prairie soils of the Selma chalk appear as soon as the little hills are reached. The bottom extends northward to the little creek that flows northeastward into the river 3 miles above the town.

At a distance of 4 miles above town the bluff on the west side of the river reaches about the same height above the water as the bluff at Columbus. It extends for 1 mile along the river as a perpendicular cliff that affords a fine section of the upper Eutaw and the base of the Selma. The low hills on the west come down to the top of the bluff. The same heavy, black prairie soils which come within 3 miles of the river due west of Columbus here reach the edge of the bluff.

The following is a section of the bluff obtained where the road comes down to the river:

$$
\text { Section of bluff of Tombigbee River } 4 \text { miles north of Columbus. }
$$

Lafayette at top.

Selma:

10. "Blue rock" of the Selma; a white to gray joint clay containing less sand at top than at bottom. In its unweathered condition the clay is pale blue, with green and black sand.. 8

Eutaw:

9. Greensand, highly calca reous, and containing numerous large oysters $\ldots \ldots \ldots \ldots \ldots \ldots$

8. Ledge of indurated greensand, calcareous, and containing same fossils as No. $9 \ldots \ldots \ldots . \quad 12$

7. Lighter colored sand, containing very few small fossils and no large ones............. 14

6. Greensand, nonfossiliferous, $\ldots, \ldots, \ldots, \ldots, \ldots, \ldots, \ldots, \ldots, \ldots, \ldots, \ldots, \ldots, \ldots, 6$ 
Eutaw-Continued.

Ft. in.

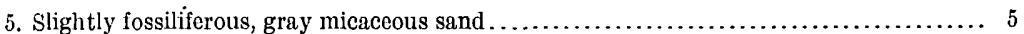

4. Ledge of indurate sand, slightly fossiliferous .................................... 10

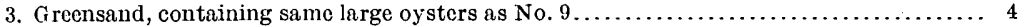

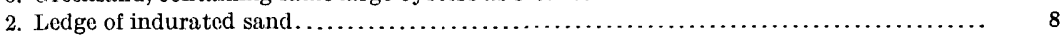

1. Fossiliferous greensand to the water's edge $\ldots \ldots \ldots, \ldots, \ldots, \ldots, \ldots, \ldots, \ldots, \ldots, \ldots, 4$

The prairie soil of the Selma extends to the river north of Columbus, but is not found east of the river. From Columbus southward to the south side of McCowers Creek on the west side of the river the Tombigbee bottom ranges in width from 2 to 4 miles. South of this creek the bottom changes again to the east side, and the Selma extends to the river.

At the mouth of James Creek the same joint clay that is seen above Columbus occurs on the east bank of the creek, about 10 feet above the water's edge.

Eight miles east of Columbus, on the Columbus and Tuscaloosa road, the hills of the Tuscaloosa formation first appear. On the hill near the 8-mile post the highly stratified clay, interbedded with various colored sands, outcrops on the side of the road.

At Steens Station the creek is cutting into the Eutaw sands.

Where the road crosses Yellow Creek the foundation of the bridge is built on the compact sand, which here is of a deep-gray color and very homogeneous in character.

One mile south of Strongs, on the Monroe and Clay county line, the Illinois Central Railroad has cut into the Selma clay to a depth of 15 feet.

Eutaw sands extend west of the town of Aberdeen for 2 miles. Here the post-oak lands begin, and the regular prairie soils one-half mile farther west. There are no outcrops of the Selma from Aberdeen to Prairie Station. The first outcrop found northwest of Aberdeen is at Strongs. Here, as farther south, outcrops of the Selma are very few on its eastern edge.

The following four analyses are of samples of limestone from various points in Oktibbeha County:

Analyses of Selma limestone from Oktibbeha County.

[By W. F. Hand, State chemist.]

\begin{tabular}{|c|c|c|c|c|c|}
\hline & 1. & 2. & 3. & 4. & Average. \\
\hline Silica $\left(\mathrm{SiO}_{2}\right) \ldots \ldots \ldots \ldots \ldots \ldots \ldots \ldots \ldots \ldots \ldots$ & 2.89 & 2.33 & 3.03 & 2.55 & 2.70 \\
\hline $\begin{array}{l}\text { Alumina }\left(\mathrm{Al}_{2} \mathrm{O}_{3}\right) \\
\text { Iron oxide }\left(\mathrm{Fe}_{2} \mathrm{O}_{3}\right) \ldots \ldots \ldots \ldots \ldots \ldots \ldots\end{array}$ & 1.53 & 1.72 & 1.92 & 1.96 & 1.78 \\
\hline Lime carbonate $\left(\mathrm{CaCO}_{3}\right) \ldots \ldots \ldots \ldots \ldots \ldots \ldots \ldots \ldots \ldots$ & 94.10 & 94.35 & 93.60 & 94.07 & 94.03 \\
\hline Magnesium carbonate $\left(\mathrm{MgCO}_{3}\right) \ldots \ldots \ldots \ldots \ldots \ldots$ & 1.84 & 1.82 & 1.64 & 2.12 & 1.85 \\
\hline 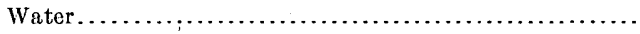 & .36 & .44 & .42 & .52 & .44 \\
\hline
\end{tabular}

The following analysis of a sample of the Selma chalk from near Okolona, Chickasaw County, Miss., is an old one, made by Doctor Hilgard. $a$ Of the material reported as "insoluble," probably about two-thirds was silica, the remainder being alumina and iron oxide.

Analysis of Selma limestone from Okolona.

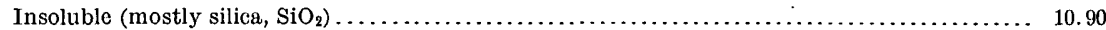

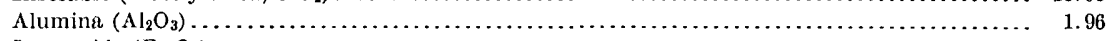

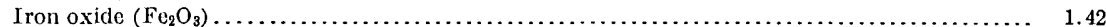

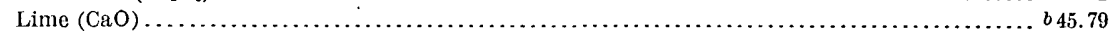

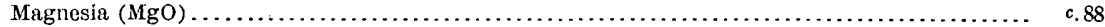

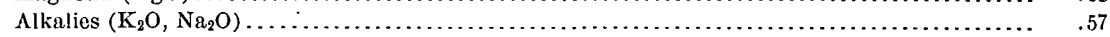

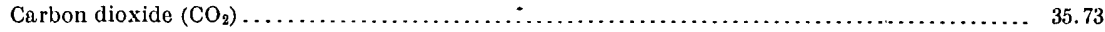

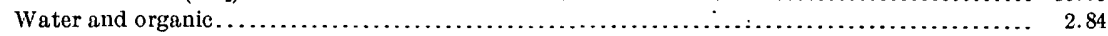

$a$ Geology and Agriculture of Mississippi, 1860, p. 101.

$b$ Equals lime carbonate $\left(\mathrm{CaCO}_{3}\right), 81.77$.

c Equals magnesium carbonate $\left(\mathrm{MgCO}_{3}\right), 1.84$. 


\section{TERTIARY LIMESTONE (VICKSBURG LIMESTONE).}

A narrow belt of limestone of Tertiary age crosses the State, in a direction a little north of west, from near: Waynesboro to Vicksburg. This is the Vicksburg limestone, which is equivalent to the upper part of the St. Stephen limestone of Alabama. The relations which exist may be indicated as follows:

\section{Mississippi.}

Alabama.

$\begin{aligned} & \text { Vicksburg limestone....... } \\ & \text { Jackson marls and clays... }\end{aligned}=$ St. Stephen limestone.

A very detailed description of the characters and composition of the St. Stephen limestone, as shown in its Alabama outcrop, is given by Doctor Smith on pages 77 to 81 of Bulletin No. 243, while in Pl. I the outcrop across Alabama and Mississippi of the St. Stephen and the Vicksburg-Jackson is indicated.

In Mississippi the Vicksburg limestone usually outcrops in a low ridge that trends generally a little north of west. The southern slope of this ridge is gentle, but its northern face is a sharp declivity, which makes it easy both to locate the outcrop and to quarry the limestone.

The Vicksburg limestone carries usually from 80 to 95 per cent of lime carbonate, with very little magnesium carbonate. Occasionally, however, more clayey phases are encountered, but in general this formation may be everywhere regarded as a possible source of Portland cement material.

The analysis below was recently made on a sample taken several miles south of Jackson, Hinds County:

\section{Analysis of Vicksburg limestone from near Jackson.}

[By G. T. Hetherington.]

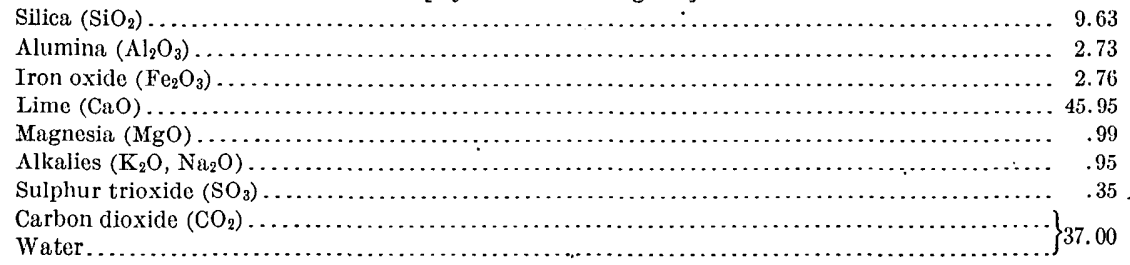

This corresponds to a content of about 81 per cent lime carbonate, and as the rock is otherwise satisfactory the addition of a little clay will make a suitable Portland cement mixture.

The analyses below were published in the early reports of the Mississippi geological survey. The last two, and perhaps the other three also, were made by Dr. E. W. Hilgard.

Analyses of Vicksburg limestones.

\begin{tabular}{|c|c|c|c|c|c|}
\hline & 1. & 2. & 3. & 4. & 5. \\
\hline Silica $\left(\mathrm{SiO}_{2}\right) \ldots \ldots \ldots \ldots$ & 6.30 & 15.05 & 9.20 & 2.03 & 12.31 \\
\hline 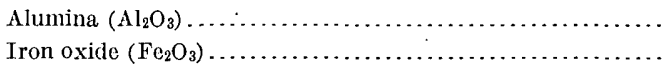 & 7.20 & 5.35 & 6.65 & 2.12 & 2. 70 \\
\hline 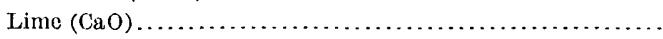 & 48.44 & 44.58 & 47.12 & 52.47 & 43.93 \\
\hline Magnesia $(\mathrm{MgO}) \ldots \ldots \ldots \ldots \ldots \ldots \ldots \ldots$ & $a \mathrm{n}, \mathrm{d}$. & n. d. & n. d. & .67 & 1.69 \\
\hline Alkalies $\left(\mathrm{K}_{2} \mathrm{O}, \mathrm{Na}_{2} \mathrm{O}\right) \ldots \ldots \ldots \ldots \ldots \ldots \ldots \ldots \ldots \ldots \ldots$ & n. d. & n. d. & i. d. & n. d. & .79 \\
\hline Sulphur trioxide $\left(\mathrm{sO}_{3}\right) \ldots \ldots \ldots \ldots \ldots \ldots \ldots \ldots$ & n. d. & n. d. & $\mathrm{n}$ d. & n. d. & 1.27 \\
\hline Carbon dioxide $\left(\mathrm{CO}_{2}\right) \ldots \ldots \ldots \ldots \ldots \ldots \ldots \ldots \ldots \ldots \ldots \ldots \ldots$ & 38.06 & 35.02 & 37.03 & 41.53 & 34.72 \\
\hline 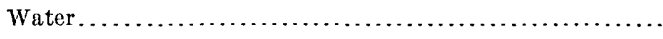 & n. d. & n. d. & n. d. & 1.10 & 2.40 \\
\hline
\end{tabular}

$a$ n. d. =not determined.

1-3. Red Hills, Wayne County: Harper, Geology of Mississippi, 1857, p. 166.

4. Brandon, Rankin County: Hilgard, Geology and Agrisultire of Mississippi, 1860.

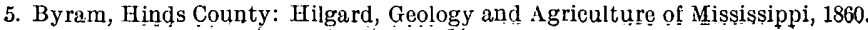




\section{BUTLDING STONE.}

The building stones of Mississippi include sandstones and limestones. The limestones have already been described under the heading "Cement materials" (pp. 76-84).

Sandstones from three different geologic formations occur in the northeastern, central, and southern parts of the State. The sandstone from the Chester formation of Tishomingo County is well suited for a durable building stone, but in no place has it been worked, on account of the distance from a railroad or navigable stream. The stone would be easily worked. It occurs in strata 150 feet thick or more along Bear Creek.

The buhrstone of Carroll, Attala, Leake, and Neshoba counties furnishes a hard quartzitic sandstone, which would be well adapted for building stone, railroad ballast, and perhaps glass sand. The cementing material is silica. When freshly dug from below the surface the sandstone is very white, and soft enough to be easily worked. . No use is made of this stone except for local purposes, such as foundation stones for houses, etc.

The old capitol building at Jackson was built of Grand Gulf sandstone from near Raymond. The large amount of iron pyrites, in changing from the sulphide to the oxide condition, cracked the stone, and on this account the stone has been abandoned.

Investigation of sandstone from various parts of the Grand Gulf group has shown that the rock varies from a very soft, loosely cemented sand to a hard though somewhat clayey sandstone practically free from iron pyrites.

A quarry is now being opened at Star, Rankin County, by the Indiana and Mississippi Stone and Timber Company. The following is an analysis and test made of the stone by R. W. Evans, director of the chemical laboratory of Purdue University:

I have made an examination of the sample of stone received from you and described as " Eureka stone from Star, Rankin County, Miss., the deposit being the property of the Indiana and Mississippi Stone and Timber Company (Limited)."

Pieces of the sample were subjected for a considerable time to the greatest heat of the gas-blast lamp, some specimens being heated gradually, others as suddenly as possible, to a bright red heat. In no case was there any sign of melting or of cracking or crumbling, the pieces retaining their original form perfectly, and being quite unchanged in appearance. From the nature of the stone (sandstone) it is also certain that no general chemical change results from this heating, as would occur in limestone.

\section{ROAD MATERIALS.}

Limestones suitable for making roads are found in Tishomingo County. They belong to the Paleozoic rocks and are found only along Tennessee River and its tributaries. The white oolitic limestone of the St. Louis and the more siliceous limestone of the Tullahoma make excellent ballast and road material when crushed.

Sandstone is more widely distributed than the limestones. It overlies the limestone along Bear Creek in Tishomingo County and extends several miles farther south. The Paleozoic sandstone is not good, lasting road material. Constant travel over it soon pulverizes it and reduces it to sand.

The most desirable sandstone for cornmon road material and railroad ballast is the semiquartzite belonging to the Tallahatta buhrstone. It would be more expensive to crush than the limestones, but when once reduced to the proper size it would be more lasting. The largest deposit of the Tallahattr occurs 4 to 5 miles north of Kosciusko.

The Grand Gulf sandstone has been tried for a road material, but has been found to be too soft and rotten.

\section{GRAVEL. OR SHINGLE.}

The cheapest and most available road material in the State is shingle or Lafayctte gravel. These deposits are widely scattered over various parts of the State, but in only two sections are they of sufficient thickness and extent to become of great economic importance. One of the areas is along the eastern border of the Cretaceous near the foothills of the older rocks in Tishomingo and Itawamba counties. These deposits are often 50 to 75 feet thick and cover large areas. A large per cent of the gravel is quartz, which makes a very desirable road material for constant wear. Intermingled with the gravel is a ferruginated mixture of 
sand and clay, which forms a natural cement. When placed upon a street or railroad the rains and constant travel over it cause the material to cement into a rock-like mass. Some railroad men object to the gravel from the eastern section of the State because it often cements so tightly that it prevents the ties from drying out and makes the roadbed too rigid. This cementing quality makes it all the more desirable for common road material.

When shipped for any great distance over the railroads gravel becomes an expensise road material. In Coahoma County experiments have recently been made in building roads with gravel from Tishomingo County. The cost of grading and putting a layer of gravel 8 inches thick in the center of the road was $\$ 5,000$ per mile, or $\$ 50$ per carload.

The other section of the State where gravel is present is along the western half. This is more extensive than the eastern area, but the deposits are much thinner, the gravel in many places being but a few inches thick. The gravel of the western area does not possess the cementing qualities of the Tishomingo gravel. It is little more than a mass of round, waterworn pebbles which when used as a road material are easily pushed aside by wheels of vehicles and horses' feet. For this reason it has been called "crawling gravel." Where used as a railroad ballast it is greatly improved by being mixed with sand and clay.

\section{BURNED CLAY.}

In some of the later formations of the State there is a bluish-gray to dark-colored tough gumbo clay which has been experimented on for making roads. This clay is found throughout the Yazoo delta region, except where it is covered by silts and sands along the streams.

Some of the citizens of Clarksdale, Coahoma County, have thought for some time that this tough gumbo clay could be burned and utilized for a road material. They accordingly interested the National Government.in the matter and a man was sent there during the fall of 1903 to make an experiment with the clay for this purpose. The road was first.graded, the center of the roadbed raised, and good ditches cut on either side. Two rows of $\operatorname{logs} 6$ to 8 inches in diameter were placed on either side of the roadbed, parallel to it, and these were cross laid with good, solid, dry wood, of sufficient amount when burned to completely dehydrate the clay. Enough clay was then thrown upon the wood to make about 8 to 10 inches of clinker in the center of the roadbed. After the wood is all burned to an ash the overlying burned clay settles down on the roadbed and the road is then ready for travel.

A specimen of the unburned clay used at Clarksdale was analyzed in the laboratory of the United States Geological Survey and was found to contain 8.69 per cent of chemically combined water. A specimen of the burned clay was also analyzed and it was found to be practically dehydrated. The following are the analyses of the two clays:

Analyses of clay used in road experiment at Clarksdale.

\begin{tabular}{|c|c|c|}
\hline v & $\begin{array}{l}\text { Un- } \\
\text { burned } \\
\text { clay. }\end{array}$ & $\begin{array}{l}\text { Burned } \\
\text { clay. }\end{array}$ \\
\hline 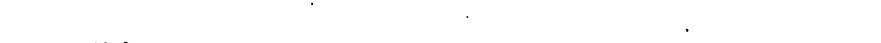 & Per cent. & Per cent. \\
\hline Loss at $107^{\circ} \ldots \ldots$ & 5.32 & 0.10 \\
\hline Loss by ignition... & 8.69 & .21 \\
\hline
\end{tabular}

The road was constructed at a cost of $\$ 2,000$ per mile. This included grading, fuel, and labor. After giving the road a fair test Walter Clark, of Clarksdale, asserts that it has been satisfactory. It is easier on the horses' feet and vehicles and does not get dusty or muddy. A more thorough test is now being made on another road near Clarkșdale. Should the experiment prove to be successful the question of road building throughout the delta will be solved and the condition of the country greatly improved. 


\section{METALILIFEROUS ORES.}

During the progress of the present field work in Mississippi many localities were examined at which ores of gold, silver, lead, and copper were said to occur, but such examinations always resulted in failure to find even a trace of the reported metal. Occasionally masses of galenite (lead sulphide) are found at many localities in the State, but it seems certain that they were brought by the Indians from the lead district of Missouri. It is safe to say that there is practically no possibility of finding a workable deposit of gold, silver, copper, lead, zinc, or tin ores in the State of Mississippi. With regard to iron ores the case is different, but even for them the prospect is not encouraging.

\section{GLASS SAND AND SILICA.}

An inexhaustible supply of building and molding sands is found in the Wilcox formation of northern Mississippi. Good glass sands are present at Jackson, Byram, and various other places along Pearl River (Pl. IV, $A$, p. 32).

One mile from Tennessee River, in 'Tishomingo County, is a laige deposit of pure-white fine-grained silica. It occurs in a horizontal bed 8 to 10 feet thick. It was formerly mined for an adulterant, but its whiteness and purity render it a valuable material for making glass. Thousands of tons of it were mined without any evidence of exhaustion. The Chester sandstone in southern Tishomingo County is another source of a desirable glass sand.

\section{OIL AND GAS.}

The development in recent years of large oil and gas bodies near the Gulf coast in Texas and Louisiana has given rise to the idea that similar bodies may be found in Mississippi. This idea is based on the assumption that geologic conditions in southern Mississippi are practically similar to those in the Beaumont and Sour Lake districts. It can be stated positively that this assumption is entirely erroneous and that no large oil pools of the Beaumont type can be expected to occur in Mississippi. If oil is found at all it must be in entirely different strata and under different geologic conditions.

Small local accumulations of oil or gas are occasionally struck in drilling wells for water, but none of eommercial value have ever been encountered. Interesting but commercially unimportant flows of gas are of frequent occurrence in the Yazoo delta. The following description of such a flow is taken from the notebook of Dr. Eugene A. Smith, now State geologist of Alabama. The observation was made in 1871.

These wells are about 1 mile from Walnut Ridge Place, in sec. 2 or 3 , T. 13, R. 9 W., 100 yards or so from the line between Tps. 13 and 14. One of the jets is ignited and has been burning for three months or more. The gas issues from a tube about 2 inches in diameter, and the flame is about 3 fect long. Four of these pipes were driven down, and the record is that after passing through about 45 feet of the ordinary soft strata the tubes struck a hard substance into which no amount of driving could make them penetrate; the hammer would rebound and no impression would be made. The first tube was then drawn up and another was driven down a few yards distant, with the same result. They tried again, going about 50 yards away, and again the hard substance was reached. Again they moved 200 yards away and again the same result. It was noticed that some gas issued from the holes made by the tubes, and on applying fire the gas was ignited. The tube was left in the last well and the gas from it is now burning.

\section{COAL AND LIGNITE.}

It can be stated with certainty and without reserve that true coal does not exist in Mis- . sissippi. At frequent intervals the newspapers report the discovery of coal deposits, but on examination the "coal" thus discovered is invariably found to be merely lignite. At the St. Louis Exposition of 1904 specimens of bituminous coal were shown in the Mississippi exhibit. These specimens, however, were not collected from any locality in Mississippi, but were sent in from mines located in Alabama, a considerable distance east of the State line.

At present the lignites of the State are of little economic importance owing to the cheapness of coal and the great abundance of wood. The vast quantities of pure lignite in the Eocene beds will doubtless be drawn on when the forests are destroyed and coal becomes 
scarce. But little effort has been made to test the heating qualities of the lignite. The few analyses which have been made show it to be high in carbon and comparatively low in sulphur. There is doubtless a future for the lignite in the making of producer gas.

Lignite occurs also in various localities in the lower Cretaceous. The deposits, however, are uniformly in very thin veins-too small to be mined profitably. It always occurs in connection with clays which contain lignitic matter. In fact, the black lignite-bearing clays are often mistaken for lignite. The thickest bed of lignite so far known in the lower Cretaceous occurs one-half mile enst of Reedsville, Itawamba County. This bed is 20 inches thick and is comparatively free from impurities. Overlying the lignite is a band of ferruginous sandstone 3 to 4 inches thick, and over this in turn are beds of stratified sands. Underlying the lignite is a stratum of white stoneware clay. The lignite outcrops near the foot of the hills east of Tombigbee River between Fulton and Tilden. Lignite is also reported to have been struck in wells at Amory, Nettleton, Aberdeen, and numerous places along the Tuscaloosa area.

A greater or less amount of lignite is found throughout the Tertiary. The purest and thickest deposits occur in the lower and middle parts of the Eocene. In southeastern Lafayette, northern Calhoun, and southwestern Pontotoc counties outcrops of lignite are numerous, and the seams are in places thick enough to be mined. A seam 28 inches thick occurs in sec. 33, T. 9 S., R. 2 W. In a.well at Paris a bed 6 feet thick is reported. Another outcrop on J. A. Head's land in sec. 11, T. 11 S., R. 2 W., shows a vein 5 feet thick. A sample from this seam was exhibited at the World's Fair at St. Louis. It is of a deep-brown color when damp, but becomes darker when dry. Unlike true bituminous coal it thoroughly disintegrates when it is exposed to the air for a few hours.

The following are analyses of lignite from Calhoun County:

Analyses of lignite from Calhoun County.

[By Alfred F. Brainard, of Birmingham, Alạ.]

\begin{tabular}{|c|c|c|}
\hline & 1. & 2. \\
\hline 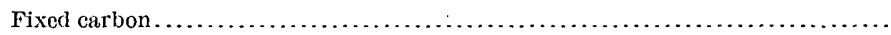 & 37.320 & 34.250 \\
\hline 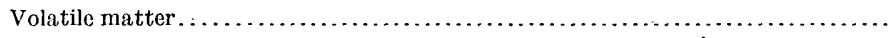 & 46.030 & 50.200 \\
\hline 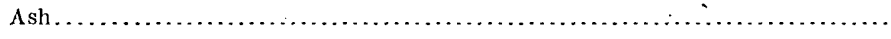 & 2.840 & 6.240 \\
\hline \multirow[t]{2}{*}{ Moisture............................................. } & 13.910 & 9.310 \\
\hline & 100.100 & 100.000 \\
\hline
\end{tabular}

The town of De Kalb is near the eastern edge of the Wilcox formation. One and a half miles northeast of the town, on Sucarnochee Creek, is a deposit of lignite 3 feet thick, which outcrops a few feet above the bed of the creek. This deposit has been opened up with a view of developing the vein. A level was run 20 feet into the hill and considerable lignite was taken out. It was found to be of excellent quality and was burned in the office of the chancery clerk, S. O. Bell, at De Kalb. The following analyses were made, No. 1 by J.C. Long; and No. 2 by R. T. Pittman:

Analyses of lignite from De Kalb.

\begin{tabular}{|c|c|c|}
\hline & 1. & 2. \\
\hline Fixed carbon........... & 41.83 & 40.80 \\
\hline Volatile matter........... & $46.82^{\circ}$ & 41.48 \\
\hline$\Lambda \operatorname{sh} . \ldots \ldots \ldots \ldots \ldots \ldots \ldots$ & 7.94 & 17.64 \\
\hline Moisture...................................... & 2.13 & n.d. \\
\hline Sulphur................................................ & 1.28 & 1.57 \\
\hline 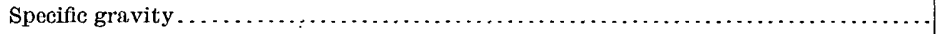 & n. d. & 1.33 \\
\hline
\end{tabular}


The lignite is overlain by a bed of gray clay and this by stratified red, yellow, and white sand, with occasional beds of ferruginous sandstone in the sand. On these hills there is a deposit of Lafayette that reaches in places $a$ thickness of 20 feet, and in this there is considerable ferruginous sandstone.

One of the distinguishing features between the Tertiary lignites of Mississippi and the true coals of the Carboniferous is in the mode of occurrence. True coals are almost always overlain by beds of compact shale which forms a "roof" over the coal. The roof is of great service in timbering the mine. In the Tertiary lignites the roof of shale is always wanting. Thin bands of ferruginous sandstone overlying the lignite seams are often mistaken for the true roof.

\section{OCHER.}

A beautiful red ocher underlying a large area east of Iuka, Tishomingo County, deserves special mention. It occurs in large bodies very similar to the white-clay deposits. It is of a pale-scarlet color, with small dark-brown specks of vegetable matter which has not changed as much as the main body; small particles of white clay also appear through it. The best exposures are found on R. F. Thorne's land, 6 miles northeast of Iuka, where it was formerly obtained and shipped for making paint, but this body has for some cause been abandoned. Other outcrops occur on Mr. Moore's place, 2 miles east-southeast of Iuka, and at LakeComo, just outside the town.

\section{PHOSPHATES, GREENSANDS, MARLS, AND OTHER FERTILIZERS.}

Natural fertilizers occur in widely separated formations of the State. Despite the exhaustive treatise on the marls, greensands, and clays by Hilgard $a$ little attention seems to have been paid to these means of improving the productiveness of the soils by the farmers of the State. Many of the cold and exhausted soils could be greatly improved and much better crops realized by the application of these natural fertilizers.

The upper portion of the Tuscaloosa and the lower portion of the Selma formations are highly impregnated with greensand, which contains more or less carbonate of lime and potash. Where these formations come to the surface they form a belt of very productive country. These greensands might be profitably used as a dressing on the exhausted lands of the Selma chalk area farther west, where there is still a large amount of carbonate of lime, but a lack of potash.

In the upper Cretaceous, particularly in the Ripley, the marls contain an average of 15 per cent of carbonate of lime and from one-half to 1 per cent of potash. The limestones of the Midway are likewise very rich in potash.

Greensand occurs in greater or less quantities throughout the Tertiary. Its presence is detected by the added fertility of the soil. In the Claiborne, Jackson, and Vicksburg formations it is present in the calcareous clays, marls, and limestones. These marls will be of great value if applied on the thin clay or loamy soils of central and southern Mississippi.

a Hilgard, E. W., Geology and Agriculture of Mississippi, 1860. 
The following analyses of the marls of the State are taken from Hilgard's Geology and Agriculture of Mississippi:

Analyses of Mississippi marls.

[By Dr. E. W. Hilgard.]

\begin{tabular}{|c|c|c|c|c|c|c|c|c|c|}
\hline \multirow[b]{2}{*}{. } & $\begin{array}{l}\text { Clarke } \\
\text { County. }\end{array}$ & \multicolumn{4}{|c|}{ Hinds County. } & \multicolumn{2}{|c|}{$\begin{array}{l}\text { Warren } \\
\text { County. }\end{array}$} & \multirow{2}{*}{$\frac{\begin{array}{c}\text { Rankin } \\
\text { County. }\end{array}}{\text { Dr. Quin's. }}$} & \multirow{2}{*}{$\begin{array}{l}\text { Carroll } \\
\text { County. } \\
\text { Shongalo. }\end{array}$} \\
\hline & $\begin{array}{c}\text { Garlands } \\
\text { Creek. }\end{array}$ & \multicolumn{2}{|c|}{ Jackson. } & \multicolumn{2}{|c|}{ Byram. } & \multicolumn{2}{|c|}{ Vicksburg. } & & \\
\hline Insoluble matter. ........... & 45.881 & \multicolumn{2}{|c|}{37.400} & \multicolumn{2}{|c|}{12.308} & & 20.967 & 13.074 & 55.705 \\
\hline Potash $\ldots \ldots \ldots \ldots \ldots \ldots$ & 1.717 & \multicolumn{2}{|c|}{.445} & \multicolumn{2}{|c|}{.611} & & .753 & .265 & 1.604 \\
\hline Soda.......... & .465 & \multicolumn{2}{|c|}{.208} & \multicolumn{2}{|r|}{.179} & & .283 & .031 & .045 \\
\hline Lime............ & 14. 785 & \multicolumn{2}{|c|}{28.821 . } & \multicolumn{2}{|r|}{43.932} & & 37.543 & 46.222 & .166 \\
\hline Magnesia .................. & 2.476 & \multicolumn{2}{|c|}{1.407} & \multicolumn{2}{|r|}{1.688} & & 2.082 & .614 & 1. 630 \\
\hline Brown oxide of manganese... & .403 & \multirow{3}{*}{\multicolumn{2}{|c|}{5.133}} & & & & & .067 & $\ldots \ldots \ldots$ \\
\hline Peroxide of iron...$\ldots \ldots \ldots$ & 13.020 & & & & 2.696 & & 4.722 & 2.722 & 34.347 \\
\hline Alumina .............. & 7.751 & & & & 2.090 & & 4.122 & 2.122 & 04.041 \\
\hline Phosphoric acid.... & .32 & 27 & 256 & & .224 & & .135 & Trace. & Trace. \\
\hline Sulphuric acid..... & .56 & 66 . & $\cdots \cdots$ & & 1.266 & & $\cdots \cdots \cdots$ & .058 & $\ldots \ldots$ \\
\hline Carbonic acid $\ldots \ldots \ldots \ldots$ & 12.49 & 23. & 084 & & 34.720 & & 30.838 & 34.754 & .129 \\
\hline Organic matter and water... & ….. & & 246 & & 2.396 & & 2.657 & 2.050 & 7.012 \\
\hline$\cdot$ & 99.88 & 100. & 000 & & 00.020 & & 99.980 & 99.857 & 100.638 \\
\hline & Marion & County. & $\begin{array}{c}\text { Fra } \\
\text { Cou }\end{array}$ & $\begin{array}{l}\text { anklin } \\
\text { unty. }\end{array}$ & $\begin{array}{l}\text { Lown } \\
\text { Coun }\end{array}$ & $\begin{array}{l}\text { ades } \\
\text { ty. }\end{array}$ & Tippah & h County. & $\begin{array}{l}\text { Chicka- } \\
\text { saw } \\
\text { County. }\end{array}$ \\
\hline & Barneș. & $\begin{array}{c}\text { Burnetts } \\
\text { Bluff. }\end{array}$ & Cas & ssady. & $\begin{array}{r}\text { Wav } \\
\text { ley }\end{array}$ & er- & Ripley. & $\begin{array}{c}\text { Wil- } \\
\text { hilite's. }\end{array}$ & Houston. \\
\hline Insoluble matter.......... & 77.438 & 83.691 & & 49.475 & 88. & 702 & 62.441 & 73.410 & 35.750 \\
\hline Potash ................ & .709 & .827 & & 1.242 & & 204 & .730 & .702 & .681 \\
\hline Soda....... & .101 & .268 & & .152 & & 190 & .272 & ........ & .197 \\
\hline Lime....$\ldots \ldots \ldots \ldots \ldots$ & 4.800 & .793 & & 3.190 & & 351 & 7.952 & 6. 315 & 20.558 \\
\hline Magnesia.................. & 1.248 & 1.053 & & 1.825 & & 723 & · 1.560 & .886 & 1.366 \\
\hline Brown oxide of manganese...: & .316 & .223 & & .266 & & & .160 & .050 & .305 \\
\hline Peroxide of iron............. & 2.989 & 4.394 & & 5.538 & & & 11.849 & 7.055 & 4. 190 \\
\hline Alumina $\ldots \ldots \ldots \ldots \ldots \ldots \ldots$ & 6.449 & 8.347 & & 12.587 & & 598 & 5.865 & 5.888 & 9.475 \\
\hline Phosphoric acid .......... & .111 & .148 & & .132 & & 328 & .266 & .046 & $\ldots \ldots$ \\
\hline Sulphuric acid .............. & Trace. & .022 & & .033 & . & 013 & $\ldots \ldots$. & & 1.743 \\
\hline Carbonic acid $\ldots \ldots \ldots \ldots \ldots \ldots$ & 3.372 & $\ldots \ldots \ldots$ & & 9.555 & & 472 & 9005 & 5.640 & 16. 760 \\
\hline Organic matter and water.... & 2.664 & & & 5.876 & & 303 & 9.900 & 3.040 & 8. 774 \\
\hline & 100.197 & 99.766 & & 99.871 & 99. & 884 & 101.000 & 099.992 & 99.799 \\
\hline
\end{tabular}

MINERAL WATERS.

Much attention has been paid to the numerous sulphur, chalybeate, and lithia waters of the State. Many of these have a wide reputation as medicinal waters. The water from Stafiord Spring, near Vossburg, Jasper County, is used on the Mobile and Ohio Railroad dining cars, and is shupped to all parts of the United States. Other springs and wells, which are visited yearly by numerous health seekers and are reported as shipping water for the year 1904, are Arundel Lithia Springs, near Meridian, Lauderdale County; Browns Wells, Copiah County; Castalian Springs; near Durant, Holmes County; Rawles Spring, near Hattiesburg, Perry County; and Tallaha Springs, near Charleston, Tallahatchie County. 
The mineral waters form a very important commercial product of the State. The following is the output from 1900 to 1904 inclusive:

Production of mineral waters in Mississippi from 1900 to 1904.

\begin{tabular}{l}
\hline \\
1
\end{tabular}

Among the States and Territories of the United States Mississippi ranked in 1904 nineteenth in the quantity and sixteenth in the value of the mineral waters produced; of the southern States only three produce more than Mississippi. 



\section{INDEX .}

A. Page.

Aberdeen, rocks at. . . . . . . . . . . . . 19,83

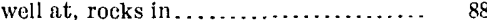

Ackerman, sections near.............. 20

Enona eufalensis, occurrence of ......... 21

Alabama-Mississippi River section, figure showing.

Alcorn County, rocks in ... $12,14,17$

Allison stoneware clay, analysis of ....... 62

description of . . . . . . . . . . . . . . . 62

Alluvium, occurrence and character of .... 7,49

Amory, well at, rocks in ............. 13, 88

Anatimya anteradiata, occurrence of ..... 21 postsulcata, occurrence of ........... 21

Anchura abrupta, occurrence of......... 21 decemlirata, occurrence of .......... 21 rostrata, occurrence of ............. 21

Anomia argentaria, occurrence of ....... 17, 21 isp., occurrence of.

Anoplotheca concava, occurrence of.......

$\Lambda$ phrodina tippana, occurrence of .........

$\Lambda$ rundel Lithia Springs, location of .......

Attala County, rocks in ............. 31,32,85

$A$ vicola subequilatera, occurrence of .......

\section{B}

Baculites anceps, occurrence of. 17,21 ovatus, occurrence of.

Baker, _, well record by ................

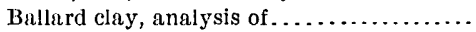
description of . . . . . . . . . . . . . . . . .

Barnes, marl from, analysis of ........... 90

Basic, rocks at and near.......... 29, 30,31

Basilosaurus sp., occurrence of........... 34

Bayou Tchula Cabawfa, clay on ........ . 70-71

Bear Creek, rocks on .............10-11, 13, 85 section on ..................... 11

Belemnitella americana, occurrence of..... 17

Benton County, clay of . . . . . . . . . . . 55-57

Big Black River, rocks on........... 34, 38,48

Bigbee Valley, wells at, record of........ 80-81

Biloxi clay, analysis of ............. 70 description of . ................. 70

Bluff formation. See Loess.

Bodea Creek, limestone on, analysis of ... . 78-79

Bogue Chitto Creek, rocks on . . . . . . . . . 79-80

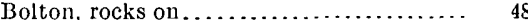

Boughton clay, analysis of ........... 57 description of ... $\ldots \ldots \ldots . .57$

Brandon, limestone at, analysis of ....... $\$ 4$

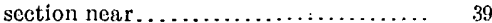

B rick plants, statistics of . . . . . . . . . 50,69

Brown clay, analysis of ............. description of ...................
B rowns Wells, location of $\ldots . . .$.

B rownsville, rocks near............... 38

Buckshot clay, occurrence and character of. $\quad 71$

Building stones, description of .......... 85

Bull Mountain Creek, rocks on ..........11,13

Burnetts Bluff, marl from, analysis of.... 90

Burns, Frank, fossils collected by ......... 33

Byram, glass sand at............... 87

glass sand at, view of $\ldots \ldots \ldots \ldots \ldots \ldots . \quad 32$

limestone at, analysis of ........... 84

marl from, analysis of............. 90

rocks at....................... 41

\section{C.}

Calcareous marls, analyses of . . . ....... 90 occurrence of . . . . . . . . . . . . . . $49,89-90$

Calhoun County, clay of............. 55 lignite in $\ldots \ldots \ldots \ldots \ldots \ldots \ldots \ldots \ldots \ldots, 88$ rocks in ..................... 20

Callicoatt clay, analysis of ............. 64 description of ................... 63

Camptonestes argillensis, occurrence of .... 21 parvus, occurrence of .............. 21

Carboniferous rocks, occurrence and cha racter of $\ldots \ldots \ldots \ldots \ldots \ldots \ldots \ldots, 10-12$

Cardita planicosta, occurrence of ........ 34 rotunda, occurrence of . . . . . . . . . . . 34

Cardium alabamense, occurrence of....... 21 dumosum, occurrence of ........... 21 eufalense, occurrence of ........... 21 tippanum, occurrence of . . . . . . . . . . 21 sp., occurrence of .................. 17

Carpenter Bluff, deposits at............ 43

Carroll County, marl from, analysis of .... 90 rocks in . . . . . . . . . . . . . . . . 29,85

Cassady, marl from, analysis of .......... 90

Cassidulus subconicus, occurrence of ........ 21 subquad ratus, occurrence of ......... 21

Castalian Springs, location of ........... 90 Cement, Portland. See Portland cement.

Cement resources, descriptions of ........ 71-84 occurrence of ................ 49

Chalybeate Spring, rocks at. . . . . . 20, 22,23

Charleston, mineral springs near......... 90

Chester formation, occurrence and character of $\ldots \ldots \ldots \ldots \ldots \ldots \ldots \ldots \ldots, 7,11-12$

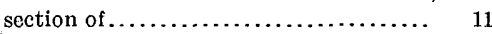
utilization of .................... 85

Chewalla, Tenn., well at, rocks in....... 19

Chickasaw County, limestone of, analysis of. $\quad 83$ marl from, analysis of .............. 90 rocks in . . . . . . . . . . . . . . 17, 19, 23,54

Chickasawhay River, fossils on ......... $35-30$ 
Page.

Chickasawhay River, rocks on......... 40,43

Choctaw County, clay of .............. 55 lignite in ..................... 28 section in.

Chonostrophia helderbergia, occurrence of . sp., occurrence of.

Chunkey, rocks near.

Claiborne group, occurrence and character of $\ldots \ldots \ldots \ldots \ldots \ldots \ldots \ldots \ldots, 28-33$ utilization of

Clarke County, fossils in .............. . 35-36 marls from, analysis of ............. 90 rocks in ....................... 29

Clarksdale, clay at.............. 86

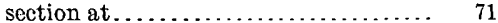
utilization of .................... 86

Clay County, rocks in . . . . . . . . . . . 17,23

Clays, descriptions of ... . . . . . . . . . . . . 50-71 occurrence of $\ldots \ldots \ldots \ldots \ldots \ldots \ldots \ldots \ldots, 49$ utilization of . ................. 50

Clays, burned, analysis of ............. $\quad \varepsilon 6$

Clays, stoneware, occurrence of

Clayton formation, occurrence and character of. sections of............

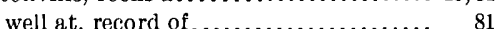

Clingscale clay, analysis of ........... 52 description of $\quad 52$

Clinton, Vicksburg limestone near, view of. 12 Coahoma, section at................. 71

Coahoma County, clay of ............. 86

Coal, kiln, analyses of ............... 74 character of ......................... nonoccurrence of ................. 87

Coffee sands, thickness of . . ............. 12

Columbus, section near . . . . . . . . . . 14, 82-83 wells at......................... 14

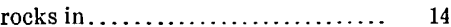

Coman clay, analysis of............. 52 description of $\ldots \ldots \ldots \ldots \ldots \ldots \ldots \ldots \ldots, 52$

Como, Lake, clay from . . . . . . . . . . . . . $\quad 50$ ocher at........................ 89

Conrad, F. A., on Jackson formation....... 34

Copiah County, mineral waters in........ 90 rocks in ....................... 42

Corbula alta, occurrence of ............ 38 crassiplica, occurrence of ............ . 21 perbrevis, occurrence of ............ . 21 subcompressa, occurrence of ......... 21

Corinth, Miss., sections near and at...... 15-16 well at, rocks in . . . . . . . . . 12, 14, 16, 19

Crassatella pteropsis, occurrence of . ...... vadosa, occurrence of................ sp., occurrence of ..................

Crenella serica, occurrence of .

Cretaceous rocks, occurrence and character of $\ldots \ldots \ldots \ldots \ldots \ldots \ldots \ldots \ldots, 7,12-22$

Crider, $\Lambda$. F., work of ................

Crippledeer Creek, rocks on ........... 12,51 section on .

Crowley Ridge, Ark., rocks on . . . ...... 48 Cuculæa vulgaris, occurrence of . ........ 17,21

Cunningham, J. B., well records by ....... 81

Cuspidaria moreauensis, occurrence of .... 21

Cypress Pond, limestone from ........... $\quad 76$ limestone from, analysis of .......,, 76
Cyprimeria alta, occurrence of . . . . . . . . . depressa, occurrence of ............. 21 Cythera sobrina, occurrence of .......... 38

\section{D.}

Dall, W. H., fossils identified by . . . . . 24, 25, 33 on Jackson formation............ 34

Dalmanites micrurus, occurrence of ....... 9 pleuropter, occurrence of ............ 9

Davidson clay, analysis of............ 54 description of . ................... 53

Davion rock, description of ........... 41

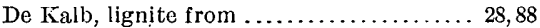
lignite from, analyses of . . . . . . . $\quad 88$

De Soto County, rocks in............. $\quad 45$

Decatur, fossils near................. 33

Dennis, clay near................... $\quad 52$

Dentalium ripleyanum, occurrence of ..... 21

Devonian rocks, fossils of ............ 9 occurrence and character of ........ 7-10

Dianchora echinata, occurrence of....... 17

Diploconcha cretacea, occurrence of...... 21

Doskie, rocks at.................... 8

Dreissena tippana; occurrence of ........ 21

Dunlap clay, analysis of .............. 61 description of . . . . . . . . . . . . 61

Durant, mineral springs near.......... 90

\section{E.}

Eckel, E. C., introduction by ......... $5-6$ on cement materials............... $71-84$

Ecru, rocks near................... 20,24 well at, record of . . . . . . . . . . . . . 19-20

Edinburg, rocks at and near........... 31

Ellistown, rocks near................ . 22 section near................... 21

Enterprise, fossils near............... 33

Eocene rocks, character of............. 7

Ethel, rocks at.................... 32

Eureka stone, description of . . . . . . . . $\quad 85$

Eutaw, Ala., rocks at ............... 13 well at, rocks in.................. 14

Eutaw sands, occurrence and character of . ................ $7,13-16,83$

Eutaw-Selma, transition between........ 14-15

Evans, R. W., on Eureka stone......... 85

Exogyra costata, occurrence of . . . . 17, 19, 21 sp., occurrence of ................ 15, 17

F.

Falling Creek, fossils on ............. 33

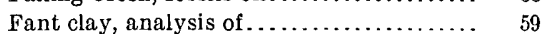
description of .................... 58

Fayette, rocks in ..................... 42

Feldsen mur, correlation of . ........... 29

Fertilizer, mineral, occurrence of ...... 49, 89-90

Fisher Creek, clay on . . . . . . . . . . . . . . 68

Flatwoods clay, correlation of ........... 23 See also Porters Creek clay.

Flatwoods country, location and character of................. 23-24,54,78

Florence, rocks at................. 41

Fort Adams, rocks at ................ 41

Fort Adams-Gattman section, figure showing .................. 9

Franklin County, marl from, analysis of... 90 rocks in $\ldots \ldots \ldots \ldots \ldots \ldots \ldots \ldots \ldots, 42$ 
Page.

Frisco fire clay, analysis of $\ldots \ldots \ldots \ldots \ldots \ldots 2,63$ description of . ................. 62

Fuller's earth, occurrence of............. 49

Fulton, rocks near................... 13

Fusus holmesianus, occurrence of........ 21 tippanus, occurrence of

\section{G.}

Gari elliptica, occurrence of . . . . . . . . . . . Garlands Creek, marl from, analysis of ..... Gas, occurrence of

Gastrochæna americana, occurrence of..... 17,21

Gattman-Fort Adams section; figure showing.

Geology, account of ................. 7-49

Gervilliopsis enslformis, occurrence of...... 21

Glass sand, bed of, view of ............ 32 occurrence of . . . . . . . . . . . . . . 49,87

Glenn, L. C., on Coffee sands........... $12^{\circ}$ on Memphis well ................ 25

Gnathodon johnsoni, occurrence of........ 40

Goldsbury, Albert, well record by........ 20

Grand Gulf, rocks at................

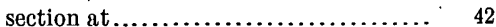

Grand Gulf group, clays of ............ $67-68$ occurrence and character of ........ 7,40-44 sections of $\ldots \ldots \ldots \ldots \ldots \ldots \ldots \ldots \ldots \ldots .42,43$ strength of $\ldots \ldots \ldots \ldots \ldots \ldots \ldots \ldots \ldots . . . \ldots \ldots$ utilization of ...................... 85

Greensand marls, analyses of ........... 90 occurrence of . . ................ 49,89-90

Greenville-West Point section, figure show-

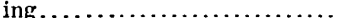

Grenada, clay from ............. 66,70 rocks near..................... 28,32

Grenada clays, analyses of . ............ 66 descriptions of . .................... 66

Grenada.County, clays of ............. 70 rocks in........................ 28

Gryphæa convexa, occurrence of ........ 19 vesicularis, occurrence of ............ 17 sp., occurrence of . .................. 17

Gulf coast, clays of ................. $70-71$

Gyrodes crenata, occurrence of.......... 21 petrosa, occurrence of ............. 17, 21

H.

Hamulus onyx, occurrence of . . . . . . . . . .

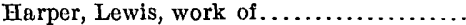

Harris, G. D., on Midway fossils..........

Harrison County, clays of ............. 70-71

Hattiesburg, mineral springs near........

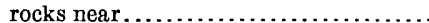

Hemiaster sp., occurrence of . . . . . . . . .

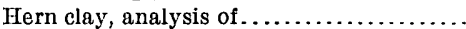
description of...

Hickory Flat, rocks at.

Hilgard, Eugene, acknowledgments t

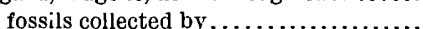

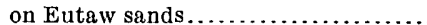
on Geological and Agricultural Survey of Mississippi............. $5-6$ on Grand Gulf group.......... 41,42,43-44 on Jackson formation. . . . . . . . . . . . 34 on Lisbon fossils.................. on Mississippi fossilı.
Hilgard, Eugene, on Port Hudson forma-

tion. . . . . . ............ 46-47

on Porters Creek clay............... 23

on Selma chalk.................... 16

on Vicksburg limestone............ 40

sections by ................. 26, 29, 38

work of. $\ldots \ldots \ldots \ldots \ldots \ldots \ldots \ldots \ldots \ldots . \quad 5-6$

Hinds County, limestone of, analyses of . : 84

marl.from, analyses of ........... 90

rocks in . . . . . . . . . . . . .

section in ........................ 36

Hoffman, section near................ 32

Tallahatta quartzite at, view of ...... 32

Holly Springs, pottery at............ $\quad 55$

section near...................... 60

stoneware clay at $\ldots \ldots \ldots \ldots \ldots \ldots \ldots \ldots .61$

analysis of ..................... 62

Holly Springs clay, analysis of .......... 61 description of ................... 61

Holmes County, mineral waters in...... 90 rocks in ....................... 29

section in ........................ 32

Homochito River, rocks on ........... 41

Houston, fossils from .............. 17 marl from, analysis of .............. 90 rocks at...................... 19

I.

Ichtyosarculites sp., occurrence of....... 17

Inoceramus argenteus, occurrence of...... $\backslash 21$ cripsi var. barabini, occurrence of ..... 21 proximus, occurrence of ........... 21 sagensis, occurrence of ............ 21

Iron ore, occurrence of . . . . . . . . . . 49,87

Itawamba County, clays in............ 53-54 gravels of $\ldots \ldots \ldots \ldots \ldots \ldots \ldots \ldots \ldots \ldots .85-86$ lignite in ......................... 88

limestones of ................... 76 rocks in . . . . . . . . . . . . . $7,11,12,13,45$ springs in . . . . . . . . 13

Iuka, clay at, analysis of............... 51 clay at, description of. . . . . . . . . . . . 50-51 ocher near...................... $\quad 89$ Tuscaloosa sands at, view of ........ . 12

\section{$\mathrm{J}$.}

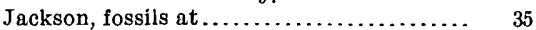

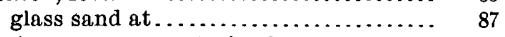
limestone at, analysis of ............ . 84 marl from, analysis of............ 90 rocks at........................ 35 utilization of ..................... 89

Jackson formation, clays of . . . . . . . . . . . 66-67 occurrence and character of . . . . . . 7, 33-37 sections of ...................... 36,37

James Creek, rocks on............ 15,81,83 well on, record of ................. 81

Jasper County, rocks in............... 37

Jefferson County, clays of. ............. 87 rocks in . . . . . . . . . $42 \ldots \ldots \ldots \ldots \ldots, \quad 42$

Johnson, L. C., acknowledgments to...... 5 fossils collected by . . . . . . . . . . . . 33 on Grand Gulf group............... 43 on Pascagoula formation........... 40

Jones County, clays of .............. 68

\section{K.}

Kemper County, clay of .............. 55 lignite in . . . . . . . . . rocks if $, \ldots \ldots, \ldots \ldots \ldots \ldots \ldots \ldots \ldots, 17,19,23,25$ 
Fennedy, E. P., clay of, analysis of ....... Pinge. pottery of ...................... 54

Kindle, E. M., fossils determined by . . . . . 7

Kirkwood Ferry, section at. ............ 29

Kosciusko, rocks near............. $30,31,85$ well at, rocks in . . . . . . . . . . . 29, 32

\section{L.}

Lafayette County, clays of ....... 55-56,63-65 lignite in ..................... 28 rocks in ................ 26,27,28,45

Lafayette formation, character of . . . 7, 13,44-46

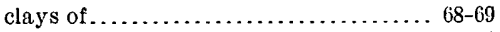
distribution of $\ldots \ldots .7,8,27,35,43 ; 44-46,78,81$ utilization of . . . . . . . . . . . . . . . $85-86$ water from ..................... 46

Lagrange group, correlation of.......... 25

Laird, clay near. . . . . . . . . . . . . . . 56 clay near, analysis of . ............. 56

Langdon, D. W., on Jackson formation... 34-35 on Oligocene beds

Lauderdale chert, correlation of ..........

Lauderdale County, lignite in.

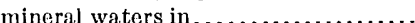
rocks in.

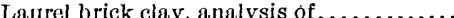
description of.

Laxispira lumbricalis, occurremco of

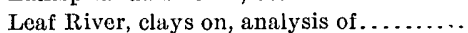

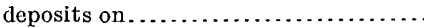

Leake County, rocks in............. 31,85

Leda longifrons, occurrence of. . ....... 17, 21 pinnaformis, occurrence of.......... 21 protexta, occurrence of............. 21

Lee County, rocks in . . . . . . . . . . . . . . 14, 17

Legumen planulatum, occurrence of . . . . . 17, 21

Leptæna rhomboidalis, occurrence of ..... 9

Leptosolen biplicata, occurrence of........ 21

Lesquereux, Leo, fossils determined by . . . . 27

Lick Creek, clay on .................. 52-53

Lignites, analyses of . . . . . . . . . . . . 88 occurrence of . . ....... 13, 25-28, 49, 78, 87-89

Lignitic formation, correlation of . ....... 25

Lima acutilineata, occurrence of . . . . . . . 17-21 reticulata, occurrence of............ 21

Lincoln County, rocks in ............... 42

Linearia metastriata, occurrence of ....... 21

Liopeplum canalis, occur rence of ......... 21 cretaceum, occurrence of .......... 21 leidermum, occurrence of ............ 21 subjugosum, occurrence of .......... 21

Liopistha bella, occurrence of . . ........ 17 protexta, occurrence of. . . .......... 17,21

Lisbon beds, occurrence and character of . .

Lithophagus ripleyanus, occurrence of.....

Lithostrotion canadense, occur rence of ....

Livingston, Ala., well at, record of........ well at, rocks in . ............. 16,76

Loess, bluff of, view of. .............. 18 occurrence and character of . . . 7, 48-49, 69-70

Loess clay, description of.

Logan, W. N., on Oktibbeha County geology .................... 19,25

Lowndes County, marl from, analysis of... 90 rocks in ................... 12, 14, 17

Lunatia obliquata, occurrence of......... 21

Lyell, Charles, on loess
M.

Page.

Mabry, 'T. O., on loess.................. 48

McCalley, Henry, on 'Tullahoma chert..... 10

McDougle mill, rocks at................. 11

McDowell clay, analysis of .............. 58 description of ..................... 58

McGee, W J, on Lafayette formation..... 45 on loess.......................... 48

McMaster mill, rocks at................ 10,11

McNutt Hill, fossils from............... 35

Mackys Creek, rocks on.................. 11

Maclin clay, analysis of................. 57 description of ..................... 56

Macon, limestone near, analyses of...... is, 82 Selma chalk at, view of............. 18

Mactra lateralis, occurrence of............ $\quad 40$

Madison County, rocks in............... 36 section in......................... 36

Madrepora mississippiensis, occurrence of. . $\quad 38$

Mahon, section near.................... 58

Map, geologic and contour, of Mississipri... 6

Marion, lignite from................. 28

Marion County, marl from, analysis of .... . .

Marls, analyses of...................... 60 occurrence of ....................... 89-90

Marshall County, clays of .......... 55-56,58-63 rocks in ......................... 26,45

Memphis, Tenn., well at, rocks in ........ 25, 28

Meridian, mineral water near............ $\quad 90$

Meristella arcuata, occurrence of ............ $\cdot 9$

Metals, ores of, occurrence of............. 87

Midway, Ala., rocks at................. 22

Midway group, occurrence and character

of.................... $7,22-25,79$

section of ......................... 24

Mineral resources, account of ........... 49-91

Mineral waters, occurrence and production

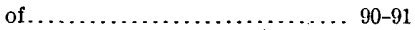

Mingo, section near.................... $\quad 11$

Mingo-Yellow Creek section, figure showing 7

Miocene rocks, character of .............. 7

Mississippi, cooperation of U. S. Geological Survey and................. 6

geology of ......................... $7-49$

map of .......................... 6

mineral resources of ................. 49-91

production of ................... 49

Mississippi, Geological and Agricultural Survey of, history of ......... $5-6$

Mississippi River-Alabama section, figure showing.

Mississippi springs, rocks at............. 41

Mississippian rocks, limestones of......... $\quad 76$ occurrence and character of........... 10-12

Mobile, well at, rocks in ................. 44

Monroe County, rocks in ......... 11, 12,14,17, 19

Montgomery County, rocks in........... 29

Moodys Branch, fossils at............. 35

Morton clay, analysis of ................ 69

description of $\ldots \ldots \ldots \ldots \ldots \ldots \ldots \ldots, 68,69$

Moss clay, analysis of .................. 64

description of ....................... 64

Muddy Creek, rocks on................. 23

N.

Naheola clay, correlation of .............. 25

Natchez, rocks at.................... 49 
Page.

Natica mississippiensis, occurrence of ...... 38 Nautilus dekayi, occurrence of .......... 17,21

Nemodon brevifrons, occurrence of....... 21 enfalensis, occurrence of............. 17,21

Neshoba County, rocks in............... 31,85

Nettleton, well at, rocks in.............. 88

New Albany, well at, record of ........... 19-20

New Scotland beds, fossils of ............ 9 occurrence and character of ........... $7-10$

Newton, fossils from, near.............. . 33

Newton County, fossils from ............. 33

Noxubee County, rocks in.......... 15, 17, 19, 23

Nucula cuneifrons, occurrence of.......... 21 percrassa, occurrence of .............. 21 perequalis, occurrence of .............. . 17 slackiana, occurrence of.............. 21

0.

Oaknoxubee River, rocks on......... 18, 77,82

Ocher, occurrence of. 49,89

Oil, nonoccurrence of ... 87

Okatibee Creek, rocks on ................. 30-31

Okolono, limestone from, analysis of...... 83

Oktibbeha County, limestone in, analysis of 83 rocks in ...................... 17, 23, 25

Oligocene rocks, character of............. 7

Orange sand. See Lafayette formation.

Orthotetes woolworthanus, occurrence of..

Ostrea falcata, occurrence of.

gigantea, occurrence of

larva, occurrence of ..................

plumosa, occurrence of .................

subspatulata, occurrence of ............

tecticosta, occurrence of............... 21

vomer, occurrence of ................ 17

sp., occurrence of................... 15, 17

Owl Creek, fossils from................. 26-21 rocks on .......................... 20

Owl Creek marl, occurrence of ...... 20,22-23,55

Oxford, pottery at. . . . . . . . . . . . . . .

Oxford clay, analysis of ................ 65 description of ...................... 64

\section{P.}

Pachycardium spillmani, occurrence of.....

Paden clay, analysis of................... description of ........................

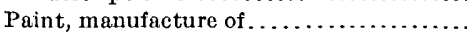

Panola County, lignite in................ rocks in ................................

Panopæa decisa, occurrence of ............

Parham clay, analysis of.... description of...

Paris well at, rocks in. acagoula formation, correlation of........ occurrence and character of.......... 7,40

Pascagoula River, rocks on.............. 43

Pearl River, glass sand on, view of........ 32 rocks on and near................. $31,34,38$

Pearson, rocks ncar.................. 42

Pecten quinquecostata, occurrence of..... 17,19 quinquenarius, occurrence of......... 21 venustus, occurrence of ............. 17

Pectunculus subaustralis, occurrence of....

$$
\text { Bull. 283-06-7 }
$$

Page.

Pennywinkle clay, analysis of............. 51 description of ..................... 51

Perissolax octolirata, occurrence of....... 17,21

Perry County, mineral waters in.......... $\quad 90$

Pholas cithara, occurrence of............. 21

Phosphates, occurrence of........... 49,89-90

Pickensville, Ala., well at, record of....... 81

Pineville, rocks near................. 39-40

Pinna laqueata, occurrence of ............ 21

Placenticera sp., occurrence of.............. 15, 17

Placuna scabra, occurrence of ............ 19

Platyceras tenuiliratum, occurrence of..... 9

Platycrinus huntsvillei, occurrence of...... 11

Plicatula saffordi, occurrence of........... 17

Pontotoc, rocks near................... 24

Pontotoc County, rocks in ............. 23, 24 well in, record of ................... 19-20

Poorhouse clay, analysis of ............ 58 description of ...................... 58

Popping clay. See Porters Creek clay.

Port Hudson formation, clays of ......... 70-71 occurrence and character of......... 7, 40-48 sections of ......................... 46

Porters Creek clay, analysis of ........... 55 description of..................... 54-55 occurrence and character of .......... 23-25 topography of ...................... 18

Portland cement, analyses of............. 73 composition of ...................... 73-74 history of ....................... $71-72$ manufacture of ..................... $72-75$ production of ...................... 72 raw materials of ............... 72-74,75-84

Portland cement plant, cost of ........... $\quad 75$ fuel for $\ldots \ldots \ldots \ldots \ldots \ldots \ldots \ldots \ldots \ldots, \quad 74$ location of ....................... 74-75 materials for ..................... $75-84$ supply for...................... 74

Post-oak land, description of........... 18-19, 80

Potteries, statistics of ................... 50

Pottery, manufacture of ............. 50-51,53

Prajrie land, description of .......... 18-19, 80

Prairie Rock, limestone near, analysis of... 79-80 rocks near........................ 18 Prentiss County, rocks in .......... 11, 12,14,17 Proetus protuberans, occurrence of ....... 9 Pterocerella tippina, occurrence of ........ 21 Pugnellus densatus, occurrence of ........ 17,21 Pulvinites argentea, occurrence of......... 21 Pyrifusus bellaliratus, occurrence of ......... 21 subdensatus, occurrence of ............ 21

Pyropsis sp., occurrence of.............. 17

\section{Q.}

Quaternary rocks, clays in ............. 70-71 occurrence and character of .......... $7,44-49$ Quilby Creek, rocks on................ 18,78

\section{R.}

Radiolites, sp., occurrence of ............ 17

Rankin County, clays of ................ 69 limestone of, analysis of................ 84 mari from, analysis of ............... 90 rocks in ........................... 37,42 
Page.

Rara Avis, rocks near

Ravine, wells at and near, record of

Rawles Springs, deposits on.. location of. .

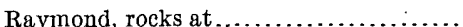

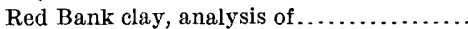
description of.

Red Hilis, limestone of, analyses of......

Redbanks, rocks at... . . . . . . . . . . . . .

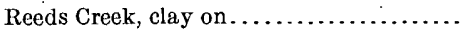
section on . . . . . . . . . . . . . . . . . .

Reedsville, clay near................. lignite near.

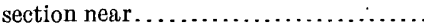

Rhipidomella oblata, occurrence of....... subcarinata, occurrence of............

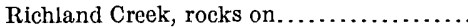

Rienzi, wells at, rocks in ...............

Ripley, marl from, analysis of. rocks near. .

sections near.

$19,20,22,24$

Ripley formation, occurrence and character of $\ldots \ldots \ldots \ldots \ldots \ldots \ldots \ldots \ldots, 7,19-22$

topography of. utilization of

Road materials, occurrence and description of . . . 85-86....

Rock Cut, Vicksburg limestone at, view of

Rocky Spring, rocks near..............

Rostellites navarroensis, occurrence of.... sp., occurrence of.

Rotten limestone, correlation of.

Russell clay, analysis of. description of

\section{$\mathrm{S}$.}

St. Louis limestone, fossils of . ......... 11 occurrence and character of ........ 7,11 utilization of.................... 85

St. Stephens formation, correlation of . . . . 33,84

Ste. Genevieve limestone, correlation of... 11

Scala americana, occurrence of. ......... 17 sillimani, occurrence of . ............ 17,21

Scaphites conradi, occurrence of........ 17,21

Schuchert, Charles, fossils determined by.

Scooba, clay at, analysis of............ 55,79 limestone near, analyses of ......... 78, 79 rocks near....................... 18

Scott County, clays of .............. 68,69 Scranton-Tennessee River section, figure

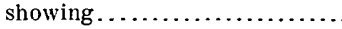

Scutella bed, correlation of

Scutella lyelli, occurrence of .............

Selma chalk, analyses of....... $77,78,79,80,82,83$

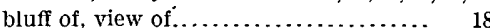
fossils of..................... 17 localities of, descriptions of . ........ 77-83 occurrence and character of . . . 7, 16-19,76-83 topography of. utilization of $\ldots \ldots \ldots \ldots \ldots \ldots \ldots \ldots, 77-83,89$

Selma-Eutaw, transition between....... 14-15 Shimek, B., on loess.

Shongalo, marl from, analysis of .........

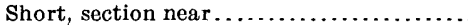

Shuqualak, limestone near, analysis of .... rocks at.

13
80
43
90
41
60
60
84
27
53
53
53
88
53
9
9
42
19
90
24
23
22
22
19
89

Simpson County, rocks in ....... on Claiborne and Jackson formations.. $\quad 33$ on Cretaceous rocks................. 16 on Grand Gulf group.............. 44 on natural gas.................... $\quad 87$ on Pascagoula formation............ 40 on Port Hudson formation........... 47 on lignitic formation .............. $\quad 25$ on Tallahatta buhrstone............ $\quad 30$ on Vicksburg limestone............ 84 work of ....................... 6

Smith County, clays of ............... 68 rocks in . . . . . . . . . . . . . . . . . 37,39

Solyma lineolata, oceurrence of ......... 21

Somerville, Tenn., fossils from . ........... 27

Sphenodiscus lenticularis, occurrence of.... 21

Spillman, William, fossils collected by..... 15

Spirifer cyclopteris, occurrence of ........ 9 increbescens, occurrence of .......... 11

Stanton, T. W., on Mississippi fossils......17, 20

Star, quarry at................... 85 rocks at................... 41,42,85 section near.................... 43

Starkville, fossils from ............... 17 well at, rocks in ................ 76

Stoneware factories, location of ........ 53 Stonington, clays of .............. 67,70 Stonington brick clay, analysis of....... 70 description of.................... 70

Stonington fire clay, analysis of........ 67 description of .................... 67

Stratigraphy, account of ............ 7 figures showing .............. $7,8,9$

Strepsidura interrupta, occurrence of ..... 21

Strongs, rocks at.................... 19

Stropheodonta beckei, occurrence of ...... 9 planulata, occurrence of ............ 9

Suanlovey Creek, fossils on............. 33

Sucarnochee series, correlation of . . . . . . 23,25

Sumerford clay, analysis of ........... 54 description of . . . . . . . . . . . . . 53

Swallow, C. G., on loess.............. 48

Synclyclonema conradi, occurrence of..... 21 simplica, occurrence of ............ 21

\section{T.}

Tallaha Springs, location of ............. 90

Tallahatchie County, mineral waters in... 90

Tallahatta buhrstone, ledge of, view of .... 32 occurrence and character of . . . . . . . 28-32 section of ....................... 32 topography of .................. 30 utilization of ................... 85

Tate County, rocks in.............. 45

Taylorsville clay, analysis of.......... 68 description of .................... 68

Tellimera eborea, occurrence of ......... 21

Tenea pinguis, occurrence of ............ 21

Tennessee River-Scranton section, figure showing ................ 9

Tentaculites gyracanthus, occurrence of ... 9

Terebratulina sp., occurrence of .......... 17

Terr clay, analysis of ................. $\quad 59$ description of $\ldots \ldots \ldots \ldots \ldots \ldots \ldots \ldots \ldots$

Tertiary rocks, limestones of........... 84 occurrence and character of . . . . .... 7,22-44 
Page.

Tinnin, rocks near.................... 38

Tippah County, clays of ................ 55

fossils from ......................... 20-21

lignite in ......................... 28

marl from, analysis of .............. 90

rocks in .................. 19,20,22,23,24

section in ......................... 24

Tishomingo County, clays in........... 50-52

glass sand in ...................... 87

gravels in ...................... $85-86$

limestone in...................... 76,85

ocher in.......................... 89

rocks in $\ldots \ldots \ldots \ldots \ldots \ldots \ldots \ldots, 7,8,11,12,13,45$

sandstone in ...................... 85

Tombigbee River, rocks on ........... 11,14,15 section on ...................... 14,82-83

Tombigbee sands, correlation of ......... 13

Trichotropis cancellaria, occurrence of..... 21

Trigonia angulicosta, occurrence of....... 21

eufalensis, occurrence of .............. 21

thoracica, occurrence of ............. 17,21

Tripoli, occurrence of ................. 49

Tullahoma formation, economic uses of .... 10 occurrence and character of ........ 7, 10-11 utilization of ..................... 85

Turner clay, analysis of ................ 51 description of ..................... 51

Turrilites alternatus, occurrence of....... 21

Turritella mortoni, occurrence of ........ 20,22 tippana, occurrence of............... 21 trilira, occurrence of ................. 21 vertebroides, nccurrence of ............ 21 sp., occurrence of ................... 17

Turritella limestone, correlation of ...... 20,22 occurrence of ....................... 55

Tuscaloosa formation, clays of ........... 50-54 occurrence and character of...... $7,12-13,83$ utilization of ........................ 13,89 view of

U.

Umbarger clay, analysis of . description of.

(n.................... 57

Unconformity, occurrence of ........... 12

Union County, rocks in ............. 22,23,24 section in $. \ldots \ldots \ldots \ldots \ldots \ldots \ldots \ldots \ldots, 21$ well in, record of $\ldots \ldots \ldots \ldots \ldots \ldots \ldots .19-20$

\section{V.}

Vaiden, section at..................... 29

Veleda lintea, occurrence of.............. 21

Veniella conradi, occurrence of ........... 17,21

Venericardia crenalirata, occurrence of..... 21

Vicksburg, marl from, analysis of......... 90

rocks near........................ 39,49 sections at....................... 38

Vicksburg clay, analysis of.............. 68 description of ..................... 67-68

Vicksburg limestone, analyses of .......... 84 occurrence and character of.... 7,34,37-40,84 outcrop of, view of . . . . . . . . . . . . . . 12 sections of .................... $36,37,38,39$ utilization of . $39-40,89$

Volutomorpha eufalensis, occurrence of.... 21 sp., occurrence of .................... 17

vossburg, rocks at ...................... 40
W.

Page.

Wahalak, limestone near, analysis of..... 79

Wahalak Creek, rocks near............. 18,79

Wailes, B. L. C., on Grand Gulf group.... 41

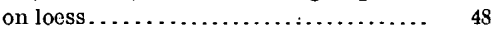

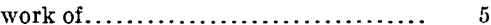

Walnut, rocks near.................... 24 section at....................... $\quad 55$

Walnut Ridge Place, gas at............. 87

Warren County, clays of ............... $67-68$ marl from, analysis of............... 90 rocks in......................... 37

Wautubbee, fossils from............... 33

Waverley, marl from, analysis of........ 90

Wayne County, fossils in............... 36 limestone of, analyses of.............. $\quad 84$ rocks in .......................... 37

Webster County, clay in............... $\quad 55$

Webster County.stoneware clay, analysis of $\quad 66$ description of ...................... 66

Wenasoga, well at, rocks in.............. 19

West Point-Greenville section, figure showing ......................... 8

Whetstone Creek, rocks on .............. 10-11 section on ......................... 10

White limestone, correlation of.......... $\quad 37$

Whitelock clay, analysis of .............. 63 description of ...................... 63

Wilcox formation, clays of . ............ $55-66$ occurrence and character of ...... 7,25-28,78 sections of ..................... 26,27,28 utilization of ..................... 27,87

Winchester, rocks near.................. 43

Winona, rocks at......................... 32

Winston County, clay of ............... 55 rocks in .......................... 23

Winston County stoneware clay, analysis of.......................... 66 description of . . . . .

Worth, rocks near...................... 31

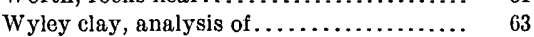
description of ...................... 63

$\mathrm{x}$.

Xenophora umbilicata, occurrence of...... Y.

Yalobusha County, lignite in............. rocks in ..........................

Yalobusha River, rocks on................. Yazoo City, loess bluff at, view of .......... rocks at.......................... 35,49

Yazoo County, rocks in................ 35

Yazoo Delta, clays of.................... $\quad 71$

Yellow Creek, rocks on.................. 8-10 section on.......................... 9 source and course of ................. 8 well on, rocks in................... 12

Yellow Creek-Mingo section, figure showing........................ 7

Yellow-loam clay, analyses of.............. 70 description of ...................... $69-70$

Yocono Creek, lignite on.................. 28

Yokahockany River, rocks on............ 30

$\mathrm{Z}$.

Zeuglodon sp., occurrence of............ 34;35 